$\bigwedge$ Supporting Information for:

\title{
The $\mathrm{SmI}_{2} / \mathrm{TEU}$-Mediated Cyclization of Unsaturated Halides
}

Chriss E. McDonald*, Holly D. Bendorf, Joseph R. Mauck, Christopher C. McAtee, Ahren I.

Green, David J. Ciccarelli, Cassandra A. Bendyk, Brandon J. Conrad, Angelique T. Delgado

Department of Chemistry, Lycoming College, One College Place, Williamsport, PA 17701, United States

1. General Information

2. Experimental Procedures

3. Supplement References

4. $\quad$ NMR Spectra
S2

S3

S32

S33 


\section{General Information.}

Dichloromethane, toluene, DMF, carbon tetrachloride, $i-\mathrm{Pr}_{2} \mathrm{NH}$, DIPEA, pyridine, 1-iodobutane, 1 bromohexane, and HMPA were distilled from $\mathrm{CaH}_{2}$ prior to use. Tetrahydrofuran was distilled from $\mathrm{Na}$ /benzophenone and, in the case of $\mathrm{SmI}_{2}$ reactions, sparged with argon for 15 min prior to use. All TEU, TPPA, and DPMPA were azeotropically dried with toluene in Schlenkware prior to use in $\mathrm{SmI}_{2}$ reactions. $n$-Butyllithium in hexanes was purchased as a $2.5 \mathrm{M}$ solution and used as received. The concentration of $\mathrm{SmI}_{2}$ in THF was confirmed by titration with $\mathrm{I}_{2} .{ }^{1} \mathbf{2},{ }^{2} \mathbf{3},{ }^{3} \mathbf{4},{ }^{4} \mathbf{5 a},{ }^{5} \mathbf{5 b - d},{ }^{6} \mathbf{8} \mathbf{b}^{7}$ Z-hex-3-en-1-yl 4methylbenzenesulfonate, ${ }^{8}$ 2-fluoro-3-hydroxypyridine, ${ }^{9}$ 2-chloro-3-hydroxyquinoline, ${ }^{10}$ 2-(4methoxyphenyl)-5-hexen-1-ol, ${ }^{11}$ methyl 3-(3-tert-butyldimethylsiloxypropyl) cyclopentene-3carboxylate, ${ }^{11}$ 4-tert-butyl-dimethylsiloxy-1-iodobutane ${ }^{12}$, and 1-bromo-3-decyne ${ }^{13}$ were made by literature procedures.

Glass-coated stir bars were used for all $\mathrm{SmI}_{2}$ reactions. All reactions were performed under nitrogen or argon atmosphere in oven-dried glassware. Reagent transfer was accomplished using gas-tight syringes. Column chromatography was accomplished using silica gel (70-230 mesh) as the stationary phase and mixtures of hexanes and ethyl acetate as the mobile phase. Thin-layer chromatography was performed using silica gel plates with fluorescent indicator. Visualization was accomplished by UV light (254 nm) or iodine. Cold baths which provided temperatures of $-98{ }^{\circ} \mathrm{C},-84{ }^{\circ} \mathrm{C},-41{ }^{\circ} \mathrm{C},-29{ }^{\circ} \mathrm{C}$ were made with $\mathrm{CH}_{3} \mathrm{OH} / \mathrm{N}_{2(1)}, \mathrm{EtOAc} / \mathrm{N}_{2(1)}, \mathrm{CH}_{3} \mathrm{CN} / \mathrm{N}_{2(1)}$, and $o$-xylene/ $/ \mathrm{N}_{2(1)}$ respectively.

NMR spectra were recorded at room temperature (400 $\mathrm{MHz}$ for ${ }^{1} \mathrm{H}$ and $100 \mathrm{MHz}$ for ${ }^{13} \mathrm{C}$ ) in $\mathrm{CDCl}_{3}$. Chemical shifts are reported in $\delta$ parts per million referenced to residual solvent proton resonance of $\mathrm{CDCl}_{3}(7.28 \mathrm{ppm})$ or the solvent carbon resonance of $\mathrm{CDCl}_{3}(77.0 \mathrm{ppm})$. Electron impact high resolution mass spectrometry was performed with double focusing sector (magnetic and electric sectors) mass analyzer. Electrospray and atmospheric pressure chemical ionization high resolution mass spectrometry were performed with quadrupole and time of flight mass analyzer. Positive ion mode was employed in all cases. 


\section{Experimental Procedures.}

\section{2-Chloro- $N$-hexyl- $N$-(3-methyl-2-butenyl)aniline (5d).}

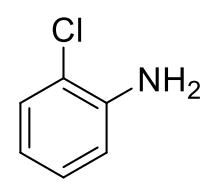

1) $n$-BuLi, THF, $-84^{\circ} \mathrm{C}$

2) $\mathrm{Br}_{\mathrm{H}_{5}}-84^{\circ} \mathrm{C}$ to $\mathrm{rt}$

3) $n$-BuLi, THF, $-84^{\circ} \mathrm{C}$

4) $\mathrm{Br} \sim-84^{\circ} \mathrm{C}$ to rt

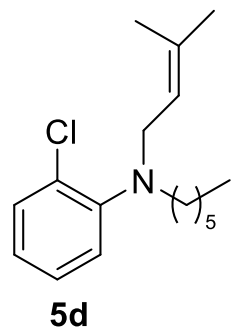

THF (22 mL) was added to $1.00 \mathrm{~g}(7.84 \mathrm{mmol})$ of 2-chloroaniline and the mixture was cooled to $-84{ }^{\circ} \mathrm{C}$. A solution of $2.5 \mathrm{n}$-BuLi in hexanes $(3.8 \mathrm{~mL}, 9.4 \mathrm{mmol})$ was added and the mixture was allowed to stir for $30 \mathrm{~min}$. 1-Bromohexane $(1.21 \mathrm{~mL}, 8.65 \mathrm{mmol})$ was added and the mixture was allowed to slowly warm to rt overnight. Water $(20 \mathrm{~mL})$ was added and the mixture extracted with hexanes $(3 \mathrm{X} 15 \mathrm{~mL})$. The extract was dried over $\mathrm{Na}_{2} \mathrm{SO}_{4}$, filtered, and concentrated under reduced pressure to provide $1.53 \mathrm{~g}$ (92\% crude yield) of $N$-hexyl-2-chloroaniline as a pale-yellow oil. THF (20 mL) was added to $1.50 \mathrm{~g}$ (7.09 mmol) of $\mathrm{N}$-hexyl-2-chloroaniline and the mixture was cooled to $-84^{\circ} \mathrm{C}$. A solution of $2.5 n$-BuLi in hexanes $(3.7 \mathrm{~mL}, 9.2 \mathrm{mmol})$ was added and the mixture was allowed to stir for $30 \mathrm{~min}$. Dimethylallyl bromide (982 $\mu \mathrm{L}, 8.51 \mathrm{mmol}$ ) was added and the mixture was allowed to slowly warm to rt overnight. Water $(20 \mathrm{~mL})$ was added and the mixture extracted with hexanes $(3 \mathrm{X} 15 \mathrm{~mL})$ and concentrated under reduced pressure. The residue was purified by column chromatography $\left(\mathrm{SiO}_{2}\right.$, hexanes) to provide $1.47 \mathrm{~g}$ of the title compound $\mathbf{5 d}(74 \%)$ as a colorless oil. HRMS (ESI) $m / z:[\mathrm{M}+\mathrm{Na}]^{+}$calcd for $\mathrm{C}_{17} \mathrm{H}_{26} \mathrm{ClNNa}$ 302.1646; found 302.1643. IR (ATR) $\mathrm{cm}^{-1} 3061,2956,2927,2856,1673,1587,1478,1440 .{ }^{1} \mathrm{H}$ NMR (400 MHz; $\left.\mathrm{CDCl}_{3} \delta, \mathrm{ppm}\right) 7.37,(\mathrm{dd}, J=8.2,1.8 \mathrm{~Hz}, 1 \mathrm{H}), 7.19,(\mathrm{~m}, 1 \mathrm{H}), 7.07(\mathrm{dd}, J=7.8,1.4 \mathrm{~Hz}$, 1H), $6.95(\mathrm{~m}, 1 \mathrm{H}), 5.26(\mathrm{~m}, 1 \mathrm{H}), 3.66(\mathrm{~d}, J=6.9 \mathrm{~Hz}, 2 \mathrm{H}), 3.08-3.02(\mathrm{~m}, 2 \mathrm{H}), 1.71(\mathrm{~s}, 3 \mathrm{H}), 1.61(\mathrm{~s}, 3 \mathrm{H})$, $1.46-1.41(\mathrm{~b}, 2 \mathrm{H}), 1.31-1.23(\mathrm{~b}, 6 \mathrm{H}), 0.89(\mathrm{t}, J=6.9 \mathrm{~Hz}) .{ }^{13} \mathrm{C} \mathrm{NMR}\left(100 \mathrm{MHz} ; \mathrm{CDCl}_{3} \delta, \mathrm{ppm}\right) 148.2$, $134.6,130.5,130.2,126.7,123.2,123.2,121.2,51.4,51.3,31.6,27.0,26.8,25.8,22.6,17.9,14.0$. 


\section{2-Chloro-3-( $N$-butyl- $N$-[3-methyl-2-butenyl])-3-pyridinamine (5e).}

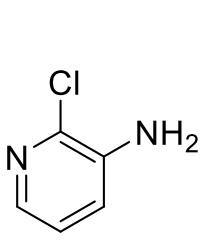

1) $n$-BuLi, THF, $-84^{\circ} \mathrm{C}$

2) $\mathrm{Br}_{X Y_{3}}-84^{\circ} \mathrm{C}$ to $\mathrm{rt}$

3) $n$-BuLi, THF, $-84^{\circ} \mathrm{C}$

4) $\mathrm{Br} \sim-84^{\circ} \mathrm{C}$ to rt

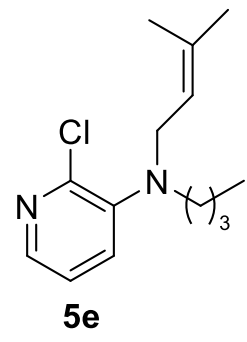

THF (26 mL) was added to $1.00 \mathrm{~g}(7.78 \mathrm{mmol})$ of 2-chloro-3-pyridinamine and the mixture was cooled to $-84{ }^{\circ} \mathrm{C}$. A solution of $2.5 n$-BuLi in hexanes $(3.7 \mathrm{~mL}, 9.3 \mathrm{mmol})$ was added and the mixture was allowed to stir for $30 \mathrm{~min}$. 1-Bromobutane $(919 \mu \mathrm{L}, 8.6 \mathrm{mmol})$ was added and the mixture was allowed to slowly warm to rt overnight. Water $(20 \mathrm{~mL})$ was added and the mixture extracted with $\mathrm{Et}_{2} \mathrm{O}(3 \mathrm{X} 15 \mathrm{~mL})$. The extract was dried over $\mathrm{Na}_{2} \mathrm{SO}_{4}$, filtered, and concentrated under reduced pressure to provide $1.10 \mathrm{~g}$ (77\% crude yield) of 2-chloro-3-( $N$-butyl-3-pyridinamine as a yellow oil. THF (15 mL) was added to $831 \mathrm{mg}$ (4.40 mmol) of 2-chloro-3-( $N$-butyl-3-pyridinamine and the mixture was cooled to $-84{ }^{\circ} \mathrm{C}$. A solution of $2.5 \mathrm{n}$-BuLi in hexanes $(2.3 \mathrm{~mL}, 5.7 \mathrm{mmol})$ was added and the mixture was allowed to stir for $30 \mathrm{~min}$. Dimethylallyl bromide (560 $\mu \mathrm{L}, 5.28 \mathrm{mmol}$ ) was added and the mixture was allowed to slowly warm to rt overnight. Water $(15 \mathrm{~mL})$ was added and the mixture extracted with hexanes $(3 \mathrm{X} 15 \mathrm{~mL})$ and concentrated under reduced pressure. The residue was purified by column chromatography $\left(\mathrm{SiO}_{2}\right.$, gradient ranging from $1 \%$ EtOAc in hexanes to $2 \%$ EtOAc in hexanes) to provide $946 \mathrm{mg}$ of the title compound 5e (85\%) as a pale-yellow oil. HRMS (ESI) $m / z$ : $[\mathrm{M}+\mathrm{Na}]^{+}$calcd for $\mathrm{C}_{14} \mathrm{H}_{21} \mathrm{ClN}_{2} \mathrm{Na}$ 275.1285; found 275.1282. IR (ATR) $\mathrm{cm}^{-1} 3049,2957,2929,2860,1673,1572,1555,1447,1404 .{ }^{1} \mathrm{H}$ $\operatorname{NMR}\left(400 \mathrm{MHz} ; \mathrm{CDCl}_{3} \delta, \mathrm{ppm}\right)$ 8.04-8.03 (m, 1H), 7.32-7.29 (m, 1H), 7.16 (dd, J= 7.8, $\left.4.6 \mathrm{~Hz}, 1 \mathrm{H}\right)$, 5.22-5.18 (m, 1H), $3.70(\mathrm{~d}, J=6.9 \mathrm{~Hz}, 2 \mathrm{H}), 3.11-3.06(\mathrm{~m}, 2 \mathrm{H}), 1.71(\mathrm{~d}, J=0.9 \mathrm{~Hz}, 3 \mathrm{H}), 1.61(\mathrm{~s}, 3 \mathrm{H})$, $1.46-1.41(\mathrm{~m}, 2 \mathrm{H}), 1.35-1.26(\mathrm{~m}, 2 \mathrm{H}), 0.89(\mathrm{t}, J=7.3 \mathrm{~Hz}, 3 \mathrm{H}) .{ }^{13} \mathrm{C} \mathrm{NMR}\left(100 \mathrm{MHz} ; \mathrm{CDCl}_{3} \delta, \mathrm{ppm}\right)$ $147.3,144.7,142.2,135.5,130.7,122.5,120.4,50.8,50.5,29.0,25.8,20.2,17.9,13.9$. 
3-(N-butyl- $N$-[3-butenyl])-2-chloropyridinamine (5f).

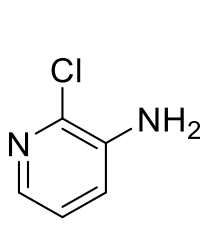

1) $n$-BuLi, THF, $-84^{\circ} \mathrm{C}$

2) $\mathrm{Br} \curvearrowright-84{ }^{\circ} \mathrm{C}$ to $\mathrm{rt}$

3) $n$-BuLi, THF, $-84^{\circ} \mathrm{C}$

4) $\mathrm{I}_{\mathrm{X}} \mathrm{Y}_{3}-84^{\circ} \mathrm{C}$ to $\mathrm{rt}$

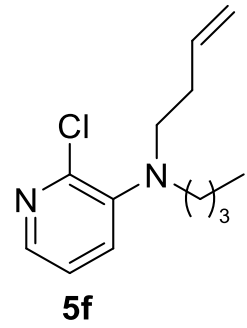

THF (26 mL) was added to $1.00 \mathrm{~g}(7.78 \mathrm{mmol})$ of 2-chloro-3-pyridinamine and the mixture was cooled to $-84{ }^{\circ} \mathrm{C}$. A solution of $2.5 n$-BuLi in hexanes $(4.1 \mathrm{~mL}, 10 \mathrm{mmol})$ was added and the mixture was allowed to stir for $30 \mathrm{~min}$. 4-Bromo-1-butene $(1.03 \mathrm{~mL}, 10.1 \mathrm{mmol})$ was added and the mixture was allowed to slowly warm to rt overnight. Water $(20 \mathrm{~mL})$ was added and the mixture extracted with $\mathrm{Et}_{2} \mathrm{O}(3 \mathrm{X} 15 \mathrm{~mL})$. The extract was dried over $\mathrm{Na}_{2} \mathrm{SO}_{4}$, filtered, and concentrated under reduced pressure to provide $0.72 \mathrm{~g}$ (51\% crude yield) of 2-chloro-3-(N-3-butenyl])-3-pyridinamine as a yellow oil. THF (7.2 mL) was added to $524 \mathrm{mg}$ (2.87 mmol) of 2-chloro-3-(N-3-butenyl])-3-pyridinamine and the mixture was cooled to - 84 ${ }^{\circ} \mathrm{C}$. A solution of $2.5 \mathrm{n}$-BuLi in hexanes $(1.4 \mathrm{~mL}, 3.4 \mathrm{mmol})$ was added and the mixture was allowed to stir for $30 \mathrm{~min}$. 1-Iodobutane (391 $\mu \mathrm{L}, 3.44 \mathrm{mmol})$ was added and the mixture was allowed to slowly warm to rt overnight. Water $(10 \mathrm{~mL})$ was added and the mixture extracted with hexanes $(3 \mathrm{X} 15 \mathrm{~mL})$ and concentrated under reduced pressure. The residue was purified by column chromatography $\left(\mathrm{SiO}_{2}\right.$, gradient ranging from $1 \%$ EtOAc in hexanes to $2 \%$ EtOAc in hexanes) to provide $417 \mathrm{mg}$ of the title compound $\mathbf{5 f}(61 \%)$ as a pale-yellow oil. HRMS (ESI) $m / z:[\mathrm{M}+\mathrm{Na}]^{+}$calcd for $\mathrm{C}_{13} \mathrm{H}_{19} \mathrm{ClN}_{2} \mathrm{Na} 261.1129$; found 261.1127. IR (ATR) $\mathrm{cm}^{-1} 3075,2957,2930,2862,1640,1571,1555,1448 .{ }^{1} \mathrm{H}$ NMR (400 MHz; $\left.\mathrm{CDCl}_{3} \delta, \mathrm{ppm}\right) 8.05(\mathrm{dd}, J=4.6,1.4 \mathrm{~Hz}, 1 \mathrm{H}), 7.37(\mathrm{dd}, J=7.8,1.4 \mathrm{~Hz}, 1 \mathrm{H}), 7.17(\mathrm{dd}, J=7.8,4.6 \mathrm{~Hz}$ $1 \mathrm{H}), 5.82-5.71(\mathrm{~m}, 1 \mathrm{H}), 5.06-4.96(\mathrm{~m}, 2 \mathrm{H}), 3.22-3.16(\mathrm{~m}, 2 \mathrm{H}), 3.15-3.10(\mathrm{~m}, 2 \mathrm{H}), 2.27-2.19(\mathrm{~m}, 2 \mathrm{H})$, $1.49-1.39(\mathrm{~m}, 2 \mathrm{H}), 1.36-1.25(\mathrm{~m}, 2 \mathrm{H}), 0.89(\mathrm{t}, J=7.3 \mathrm{~Hz}, 3 \mathrm{H}){ }^{13} \mathrm{C} \mathrm{NMR}\left(100 \mathrm{MHz} ; \mathrm{CDCl}_{3} \delta, \mathrm{ppm}\right)$ 147.6, 144.5, 142.5, 135.8, 131.1, 123.3, 116.1, 51.9, 51.9, 31.5, 29.0, 20.1, 13.9 . 


\section{Z-2-Chloro-3-(hex-3-en-1-yloxy)pyridine (5g).}

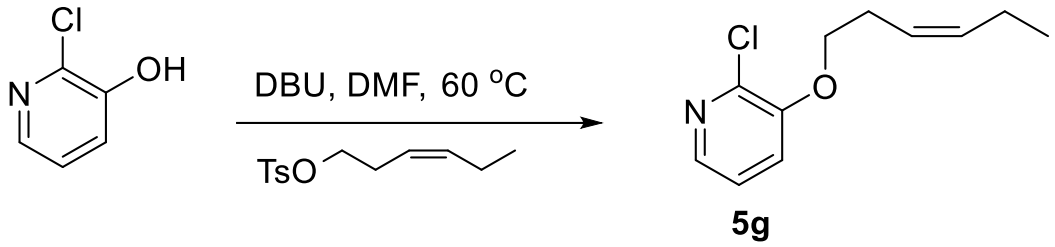

DMF (6.0 mL) was added to 2-chloro-3-hydroxypyridine $(750 \mathrm{mg}, 5.79 \mathrm{mmol}) . \mathrm{DBU}(1.29 \mathrm{~mL}, 8.69$ mmol) and Z-hex-3-en-1-p-toluenesulfonate $(2.20 \mathrm{~g}, 8.69 \mathrm{mmol})$ were added. The mixture was stirred at $60{ }^{\circ} \mathrm{C}$ with a digital hotplate stirrer for $12 \mathrm{~h}$. After cooling for $5 \mathrm{~min}$ water $(10 \mathrm{~mL})$ was added and the mixture was extracted with a 2:1 mixture of $\mathrm{Et}_{2} \mathrm{O}$ and hexanes. $(3 \mathrm{X} 15 \mathrm{~mL})$. The combined organic layers were washed with $10 \% \mathrm{NaOH}(10 \mathrm{~mL})$, water $(10 \mathrm{~mL})$, and concentrated under reduced pressure. The residue was purified by column chromatography $\left(\mathrm{SiO}_{2}\right.$, gradient ranging from $4 \%$ EtOAc in hexanes to $6 \%$ EtOAc in hexanes) to provide $1.08 \mathrm{~g}$ of the title compound $\mathbf{5 g}(88 \%)$ as a colorless oil. HRMS (EI) $m / z: \mathrm{M}^{+}$calcd for $\mathrm{C}_{11} \mathrm{H}_{14} \mathrm{ClNO} 211.0769$; found 211.0772. IR (ATR) $\mathrm{cm}^{-1} 3011,2963,2933,2874,1565$, 1448, 1419. ${ }^{1} \mathrm{H}$ NMR (400 MHz; $\left.\mathrm{CDCl}_{3} \delta, \mathrm{ppm}\right)$ 7.98-7.96 (m, 1H), 7.19-7.18 (m, 2H), 5.62-5.53 (m, $1 \mathrm{H}), 5.48-5.39(\mathrm{~m}, 1 \mathrm{H}), 4.03(\mathrm{t}, J=6.9 \mathrm{~Hz}, 2 \mathrm{H}), 2.65-2.58(\mathrm{~m}, 2 \mathrm{H}), 2.17-2.07(\mathrm{~m}, 2 \mathrm{H}), 1.00(\mathrm{t}, J=7.6$ $\mathrm{Hz}, 3 \mathrm{H}) .{ }^{13} \mathrm{C} \mathrm{NMR}\left(100 \mathrm{MHz} ; \mathrm{CDCl}_{3} \delta\right.$, ppm) 151.0, 140.9, 140.3, 134.9, 123.1, 123.0, 120.9, 68.6, 27.0, 20.6, 14.2.

\section{Z-2-Fluoro-3-(hex-3-en-1-yloxy)pyridine (5h).}<smiles>Oc1cccnc1F</smiles>

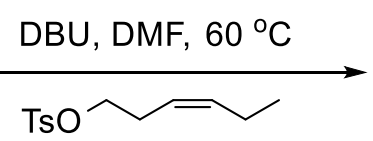<smiles>CC/C=C/CCOc1cccnc1F</smiles>

DMF (1.5 mL) was added to 2-fluoro-3-hydroxypyridine (137 mg, $1.21 \mathrm{mmol})$. DBU (0.27 mL, 1.8 $\mathrm{mmol})$ and Z-hex-3-en-1-yl 4-methylbenzenesulfonate $(0.461 \mathrm{~g}, 1.82 \mathrm{mmol})$ were added. The mixture was stirred at $60{ }^{\circ} \mathrm{C}$ with a digital hotplate stirrer for $12 \mathrm{~h}$. After cooling for 5 min water $(5 \mathrm{~mL})$ was added and the mixture was extracted with a 2:1 mixture of $\mathrm{Et}_{2} \mathrm{O}$ and hexanes. ( $\left.3 \mathrm{X} 15 \mathrm{~mL}\right)$. The combined organic layers were washed with $10 \% \mathrm{NaOH}(5 \mathrm{~mL})$, water $(5 \mathrm{~mL})$, and concentrated under 
reduced pressure. The residue was purified by column chromatography $\left(\mathrm{SiO}_{2}\right.$, gradient ranging from $4 \%$ EtOAc in hexanes to $6 \%$ EtOAc in hexanes) to provide $194 \mathrm{mg}$ of the title compound $\mathbf{5 h}(81 \%)$ as a colorless oil. HRMS (ESI) $m / z:[\mathrm{M}+\mathrm{Na}]^{+}$calcd for $\mathrm{C}_{11} \mathrm{H}_{14} \mathrm{FNNaO} 218.0952$; found 218.0949. IR (ATR) $\mathrm{cm}^{-1} 3015,2965,1604,1578 .{ }^{1} \mathrm{H} \mathrm{NMR}\left(400 \mathrm{MHz} ; \mathrm{CDCl}_{3} \delta, \mathrm{ppm}\right)$ 7.76-7.73 (m, 1H), 7.31-7.25 $(\mathrm{m}, 1 \mathrm{H}), 7.13-7.09(\mathrm{~m}, 1 \mathrm{H})$ 5.62-5.53 (m, 1H), 5.47-5.38 (m, 1H), $4.04(\mathrm{t}, J=7.2 \mathrm{~Hz}, 2 \mathrm{H}), 2.63-2.56(\mathrm{~m}$, 2H), 2.16-2.06 (m, 2H), $1.00(\mathrm{t}, J=7.3 \mathrm{~Hz}, 3 \mathrm{H}) .{ }^{13} \mathrm{C} \mathrm{NMR}\left(100 \mathrm{MHz} ; \mathrm{CDCl}_{3} \delta, \mathrm{ppm}\right) 153.8(\mathrm{~d}, J=238.9$ $\mathrm{Hz}), 142.2(\mathrm{~d}, J=25.1 \mathrm{~Hz}), 137.1(\mathrm{~d}, J=13.5 \mathrm{~Hz}), 135.0,123.1,122.7(\mathrm{~d}, J=4.8 \mathrm{~Hz}), 121.6(\mathrm{~d}, J=4.8$ $\mathrm{Hz}), 68.8,27.0 .20 .6,14.1$.

2-Chloro-3-(3-methyl-2-buten-1-yloxy)quinoline (5i).

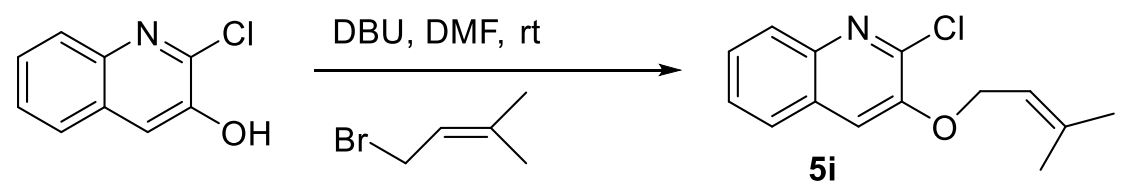

DMF (1.3 mL) was added to 2-chloro-3-hydroxyquinoline (230 mg, $1.28 \mathrm{mmol})$. DBU (290 $\mu \mathrm{L}, 1.92$ mmol) and dimethylallyl bromide $(220 \mu \mathrm{L}, 1.928 \mathrm{mmol})$ were added. The mixture was stirred at $\mathrm{rt}$ for 12 h. Water $(5 \mathrm{~mL})$ was added and the mixture was extracted with a 2:1 mixture of $\mathrm{Et}_{2} \mathrm{O}$ and hexanes. ( 3 X 5 $\mathrm{mL})$. The combined organic layers were washed with $10 \% \mathrm{NaOH}(5 \mathrm{~mL})$, water $(5 \mathrm{~mL})$, and concentrated under reduced pressure. The residue was purified by column chromatography $\left(\mathrm{SiO}_{2}\right.$, gradient ranging from 3\% EtOAc in hexanes to 7\% EtOAc in hexanes) to provide $198 \mathrm{mg}$ of the title compound $5 \mathbf{i}(63 \%)$ as a white solid. $\mathrm{mp}=72.0-73.0{ }^{\circ} \mathrm{C}$. HRMS (EI) $m / z: \mathrm{M}^{+}$calcd for $\mathrm{C}_{14} \mathrm{H}_{14} \mathrm{ClNO}$ 247.0769; found 247.0767. IR (ATR) $\mathrm{cm}^{-1} 3050,2979,2965,2940,1679,1590,1495,1420 .{ }^{1} \mathrm{H}$ NMR (400 MHz; $\mathrm{CDCl}_{3} \delta$, ppm) 7.96, (d, $\left.J=9.2 \mathrm{~Hz}, 1 \mathrm{H}\right), 7.73-7.69(\mathrm{~m}, 1 \mathrm{H}), 7.60-7.54(\mathrm{~m}, 1 \mathrm{H}), 7.54-$ $7.48(\mathrm{~m}, 1 \mathrm{H}), 7.42(\mathrm{~s}, 1 \mathrm{H}), 5.60-5.53(\mathrm{~m}, 1 \mathrm{H}), 4.71(\mathrm{~d}, J=6.9 \mathrm{~Hz}, 2 \mathrm{H}), 1.83(\mathrm{~s}, 3 \mathrm{H}), 1.81(\mathrm{~s}, 3 \mathrm{H}) .{ }^{13} \mathrm{C}$ NMR (100 MHz; $\left.\mathrm{CDCl}_{3} \delta, \mathrm{ppm}\right)$ 148.2, 143.6, 142.0, 139.4, 128.4, 128.1, 127.4, 127.2, 126.2, 118.3, $115.2,66.1,25.8,18.4$ 
1-Chloro-2-(pent-4-en-1-yloxy)naphthalene (5j).

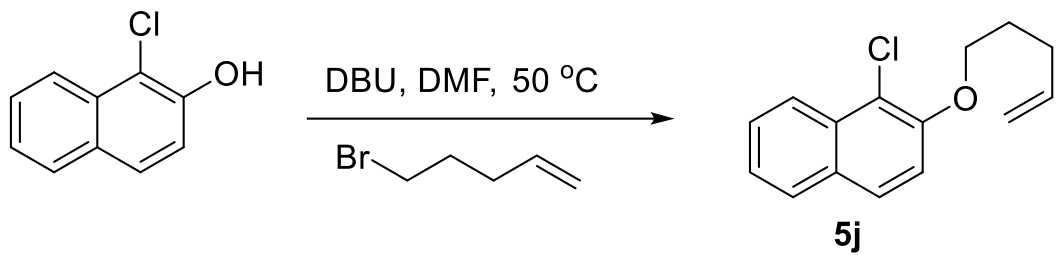

DMF (2.9 mL) was added to 1-chloro-2-naphthol (520 mg, $2.91 \mathrm{mmol}) \mathrm{DBU}(663 \mu \mathrm{L}, 4.37 \mathrm{mmol})$ and 5-bromo-1-pentene $(517 \mu \mathrm{L}, 4.37 \mathrm{mmol})$ were added. The mixture was stirred for $12 \mathrm{~h}$ at $50{ }^{\circ} \mathrm{C}$ with a digital hotplate stirrer. Water $(5 \mathrm{~mL})$ was added and the mixture was extracted with a 2:1 mixture of $\mathrm{Et}_{2} \mathrm{O}$ and hexanes ( 3 X $5 \mathrm{~mL}$ ). The combined organic layers were concentrated under reduced pressure. The residue was purified by column chromatography $\left(\mathrm{SiO}_{2}\right.$, gradient ranging from $0.5 \%$ EtOAc in hexanes to $2 \%$ EtOAc in hexanes) to provide $616 \mathbf{m g}$ of the title compound $\mathbf{5 j}$ (86\%) as a colorless oil. HRMS (EI) $m / z: \mathrm{M}^{+}$calcd for $\mathrm{C}_{15} \mathrm{H}_{15} \mathrm{ClO} 246.0811$; found 246.0818. IR (ATR) $\mathrm{cm}^{-1} 3073,2940,2878,1634,1624$, 1596, 1563. ${ }^{1} \mathrm{H}$ NMR (400 MHz; $\mathrm{CDCl}_{3} \delta$, ppm) $8.21(\mathrm{~d}, J=8.7 \mathrm{~Hz}, 1 \mathrm{H}), 7.78(\mathrm{~d}, J=8.2 \mathrm{~Hz}, 1 \mathrm{H}), 7.73$ $(\mathrm{d}, J=9.2 \mathrm{~Hz}, 1 \mathrm{H}), 7.58-7.52(\mathrm{~m}, 1 \mathrm{H}), 7.42-7.35(\mathrm{~m}, 1 \mathrm{H}), 7.25(\mathrm{~d}, J=5.0 \mathrm{~Hz}, 1 \mathrm{H}), 5.93-5.81(\mathrm{~m}, 1 \mathrm{H})$, 5.12-4.97 (m, 2H), $4.19(\mathrm{t}, J=6.4 \mathrm{~Hz}, 2 \mathrm{H}), 2.36-2.28\left(\mathrm{~m}, 2 \mathrm{H}, 2.02-1.92(\mathrm{~m}, 2 \mathrm{H}) .{ }^{13} \mathrm{C}\right.$ NMR $(100 \mathrm{MHz}$; $\left.\mathrm{CDCl}_{3} \delta, \mathrm{ppm}\right) 152.0,137.7,132.0,129.5,127.9,127.8,127.3,124.3,123.5,117.6,115.4,115.3,69.3$, $30.0,28.5$.

\section{General Procedure for the Cyclization of Unsaturated Halides.}

With $3.5 \mathrm{eq} \mathrm{SmI} \mathrm{S}_{2}$ and $7.0 \mathrm{eq} \mathrm{TEU}$. To an ice-cold mixture of $287 \mathrm{mg}$ TEU $(2.00 \mathrm{mmol})$ and $7.6 \mathrm{~mL}$ of THF was added $0.80 \mathrm{~mL}$ of a $2.5 \mathrm{M}$ solution of $n$-BuLi $(2.0 \mathrm{mmol})$ in hexanes. After cooling the mixture to the desired temperature, a solution of $0.285 \mathrm{mmol}$ of the unsaturated halide compound in $1.0 \mathrm{~mL}$ of THF was added. This mixture was stirred for $5 \mathrm{~min}$ then $10.6 \mathrm{~mL}$ of a $0.094 \mathrm{M}$ solution of $\mathrm{SmI}_{2}(1.0$ $\mathrm{mmol})$ in THF was added. The mixture was allowed to warm to $\mathrm{rt}$ and stirred overnight. Water $(8 \mathrm{~mL})$ was added and the mixture extracted with a 2:1 mixture of hexanes and $\mathrm{Et}_{2} \mathrm{O}(5 \mathrm{X} 5 \mathrm{~mL})$. The concentrated mixture was purified by silica gel column chromatography as described below. 
With $3.5 \mathrm{eq} \mathrm{SmI}_{2}$ and $14.0 \mathrm{eq} \mathrm{TEU}$. To an ice-cold mixture of $574 \mathrm{mg}$ TEU (3.99 mmol) and $6.8 \mathrm{~mL}$ of THF was added $1.6 \mathrm{~mL}$ of a $2.5 \mathrm{M}$ solution of $n$-BuLi (4.0 mmol) in hexane. After cooling the mixture to the desired temperature, a solution of $0.285 \mathrm{mmol}$ of the unsaturated compound in $1.0 \mathrm{~mL}$ of THF was added. This mixture was stirred for $5 \mathrm{~min}$ then $10.6 \mathrm{~mL}$ of a $0.094 \mathrm{M}$ solution of $\mathrm{SmI}_{2}(1.0 \mathrm{mmol})$ in THF was added. The mixture was allowed to warm to $\mathrm{rt}$ and stirred overnight. Water $(8 \mathrm{~mL})$ was added and the mixture extracted with a 2:1 mixture of hexanes and $\mathrm{Et}_{2} \mathrm{O}(5 \mathrm{X} 5 \mathrm{~mL})$. The concentrated mixture was purified by silica gel column chromatography as described below.

\section{2,3-Dihydro-1-methyl-1H-naphtho[2,1-b]pyran (6a).}

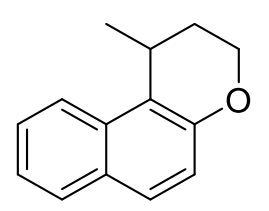

$6 a$

Compound $\mathbf{6 a}$ was synthesized from $\mathbf{5 a}$ according to the general procedure using $3.5 \mathrm{eq} \mathrm{SmI}_{2}$ and $14.0 \mathrm{eq}$ $\mathrm{TEU}^{-}$at $-98^{\circ} \mathrm{C}$ (entry 7 , Table 1$)$. The residue was purified by column chromatography $\left(\mathrm{SiO}_{2}\right.$, gradient ranging from $100 \%$ hexanes to $1 \%$ EtOAc in hexanes) to provide $47 \mathrm{mg}$ of the title compound $\mathbf{6 a}(83 \%)$ as a colorless oil. ${ }^{1} \mathrm{H}$ and ${ }^{13} \mathrm{C}$ NMR were in accord with literature spectra. ${ }^{3}$

\section{2-(But-3-enyloxy)naphthalene (7a).}

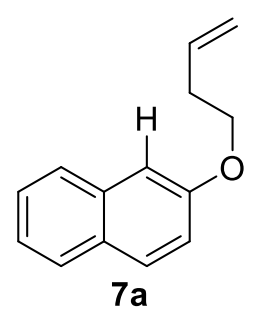

Compound 7a was synthesized from $\mathbf{5 a}$ according to the general procedure using 3.5 eq $\mathrm{SmI}_{2}$ and $14.0 \mathrm{eq}$ TEU - at $-98{ }^{\circ} \mathrm{C}$ (entry 7 , Table 1$)$. The residue was purified by column chromatography $\left(\mathrm{SiO}_{2}\right.$, gradient ranging from $100 \%$ hexanes to $1 \%$ EtOAc in hexanes) to provide $0.5 \mathrm{mg}$ of the title compound $7 \mathbf{a}(<1 \%)$ as a colorless oil. ${ }^{1} \mathrm{H}$ and ${ }^{13} \mathrm{C}$ NMR were in accord with literature spectra. ${ }^{3}$ 


\section{1,2-Dihydro-1-methylnaphtho[2.1.b]furan (6b).}

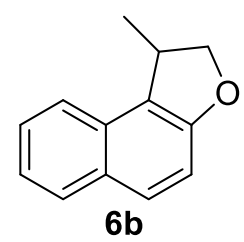

Compound $\mathbf{6 b}$ was synthesized from $\mathbf{5 c}$ according to the general procedure using $3.5 \mathrm{eq} \mathrm{SmI}_{2}$ and 14.0 eq $\mathrm{TEU}^{-}$at $-98{ }^{\circ} \mathrm{C}$ (entry 2 , Table 2$)$. The residue was purified by column chromatography $\left(\mathrm{SiO}_{2}\right.$, gradient ranging from $100 \%$ hexanes to $1 \%$ EtOAc in hexanes) to provide $37 \mathrm{mg}$ of the title compound $\mathbf{6 b}(70 \%)$ as a colorless oil. ${ }^{1} \mathrm{H}$ and ${ }^{13} \mathrm{C}$ NMR were in accord with literature spectra. ${ }^{3}$

\section{1-Hexyl-3-isopropyl-2,3-dihydro-1H-indole (6c).}

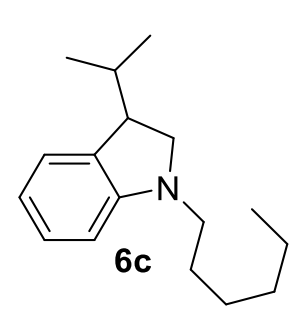

Compound $\mathbf{6 c}$ was synthesized from $\mathbf{5 d}$ according to the general procedure using 5.5 eq $\mathrm{SmI}_{2}$ and 11 eq TEU ${ }^{-}$at $-98{ }^{\circ} \mathrm{C}$ (entry 3, Table 2 ). The residue was purified by column chromatography $\left(\mathrm{Et}_{3} \mathrm{~N}\right.$ washed $\mathrm{SiO}_{2}$, gradient ranging from $100 \%$ hexanes to $0.5 \%$ EtOAc in hexanes) to provide $61 \mathrm{mg}$ of the title compound 6c (87\%) as a colorless oil. HRMS (ESI) $m / z:[\mathrm{M}+\mathrm{H}]^{+}$calcd for $\mathrm{C}_{17} \mathrm{H}_{28} \mathrm{~N}$ 246.2216; found 246.2210. IR (ATR) $\mathrm{cm}^{-1} 3046,2955,2926,2858,1687,1605,1490,1458 .{ }^{1} \mathrm{H} \mathrm{NMR}\left(400 \mathrm{MHz} ; \mathrm{CDCl}_{3}\right.$ $\delta$, ppm) 7.10-7.03 (m, 2H), 6.65-6.60 (m, 1H), $6.44(\mathrm{~d}, J=7.8 \mathrm{~Hz}, 1 \mathrm{H}), 3.38-3.33(\mathrm{~m}, 1 \mathrm{H}), 3.21-3.09(\mathrm{~m}$, 2H), 3.09-2.97 (m, 2H), 2.07-1.98 (m, 1H), 1.64-1.55 (m, 2H), 1.43-1.29 (m, 6H), 1.01 (d, J = 6.9 Hz, 3H), 0.95-0.86 (m, 6H). ${ }^{13} \mathrm{C} \mathrm{NMR}\left(100 \mathrm{MHz} ; \mathrm{CDCl}_{3} \delta, \mathrm{ppm}\right) 153.2,132.2,127.4,124.0,116.6,106.4$, $55.1,49.0,46.8,31.7,30.9,27.3,26.9,22.7,20.4,18.6,14.1$. 
$N$-Hexyl- $N$-(3-methyl-2-butenyl)aniline (7c).

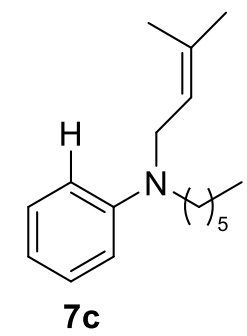

Compound 7c was synthesized from $\mathbf{5 d}$ according to the general procedure using $5.5 \mathrm{eq} \mathrm{SmI}_{2}$ and 11 eq TEU ${ }^{-}$at $-98{ }^{\circ} \mathrm{C}$ (entry 3 , Table 2). The residue was purified by column chromatography $\left(\mathrm{Et}_{3} \mathrm{~N}\right.$ washed $\mathrm{SiO}_{2}$, gradient ranging from $100 \%$ hexanes to $0.5 \%$ EtOAc in hexanes) to provide $1.4 \mathrm{mg}$ of the title compound 7c (2\%) as a colorless oil. HRMS (ESI) $m / z$ : $[\mathrm{M}+\mathrm{H}]^{+}$calcd for $\mathrm{C}_{17} \mathrm{H}_{28} \mathrm{~N} 246.2216$; found 246.2211. IR (ATR) $\mathrm{cm}^{-1} 3024,2956,2926,2856,1671,1596,1572,1503,1457 .{ }^{1} \mathrm{H}$ NMR (400 MHz; $\left.\mathrm{CDCl}_{3} \delta, \mathrm{ppm}\right)$ 7.26-7.18 (m, 2H), 6.72-6.63 (m, 3H), 5.26-5.17 (m, $\left.1 \mathrm{H}\right), 3.89(\mathrm{~d}, J=6.0 \mathrm{~Hz}, 2 \mathrm{H}), 3.31-$ $3.24(\mathrm{~m}, 2 \mathrm{H}), 1.74(\mathrm{~s}, 6 \mathrm{H}), 1.64-1.55(\mathrm{~m}, 2 \mathrm{H}), 1.39-1.29(\mathrm{~m}, 6 \mathrm{H}), 0.92(\mathrm{t}, J=6.4 \mathrm{~Hz}, 3 \mathrm{H}) .{ }^{13} \mathrm{C} \mathrm{NMR}(100$ $\left.\mathrm{MHz} ; \mathrm{CDCl}_{3} \delta, \mathrm{ppm}\right) 148.6,133.8,129.1,122.0,115.4,112.1,50.8,48.5,31.7,27.3,26.9,25.7,22.7$, 17.9, 14.1.

\section{1-Butyl-3-isopropyl-2,3-dihydro-1H-pyrrolo-[3,2-b]-pyridine (6d).}

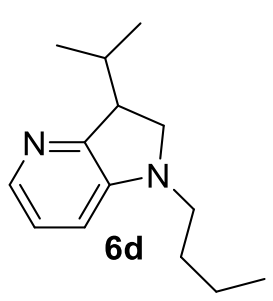

Compound $\mathbf{6 d}$ was synthesized from $\mathbf{5 e}$ according to the general procedure using $3.5 \mathrm{eq} \mathrm{SmI}_{2}$ and $14.0 \mathrm{eq}$ TEU - at $-98{ }^{\circ} \mathrm{C}$ (entry 4 , Table 2$)$. The residue was purified by column chromatography $\left(\mathrm{SiO}_{2}\right.$, gradient ranging from $2 \%$ EtOAc in hexanes to $5 \%$ EtOAc in hexanes) to provide $34 \mathrm{mg}$ of the title compound $\mathbf{6 d}$ (55\%) as a colorless oil. HRMS (ESI) $m / z$ : $[\mathrm{M}+\mathrm{H}]^{+}$calcd for $\mathrm{C}_{14} \mathrm{H}_{23} \mathrm{~N}_{2}$ 219.1856; found 219.1850. IR (ATR) $\mathrm{cm}^{-1} 3052,2955,2929,2869,1592,1576,1482,1433 .{ }^{1} \mathrm{H}$ NMR (400 MHz; $\left.\mathrm{CDCl}_{3} \delta, \mathrm{ppm}\right) 7.71$ $(\mathrm{dd}, J=5.0,0.9,1 \mathrm{H}), 6.89(\mathrm{dd}, J=8.2,5.0,1 \mathrm{H}), 6.55(\mathrm{dd}, J=8.2,0.9 \mathrm{~Hz}, 1 \mathrm{H}), 3.48-3.40(\mathrm{~m}, 1 \mathrm{H}), 3.28-$ 
$3.18(\mathrm{~m}, 2 \mathrm{H}), 3.08-3.02(\mathrm{~m}, 2 \mathrm{H}), 2.35-2.23(\mathrm{~m}, 1 \mathrm{H}), 1.63-1.54(\mathrm{~m}, 2 \mathrm{H}), 1.46-1.35(\mathrm{~m}, 2 \mathrm{H}), 1.06(\mathrm{~d}, J=$ $6.9,3 \mathrm{H}), 0.98(\mathrm{t}, J=7.3 \mathrm{~Hz}, 3 \mathrm{H}), 0.86(\mathrm{~d}, J=6.9 \mathrm{~Hz}, 3 \mathrm{H}) .{ }^{13} \mathrm{C} \mathrm{NMR}\left(100 \mathrm{MHz} ; \mathrm{CDCl}_{3} \delta, \mathrm{ppm}\right) 155.5$, $146.9,136.9,121.8,110.8,52.6,48.1,47.5,30.2,29.1,20.5,20.3,17.9,13.9$.

\section{1,2,3,4-Tetrahydro-1-butyl-4-methylnaphthyridine (6e).}

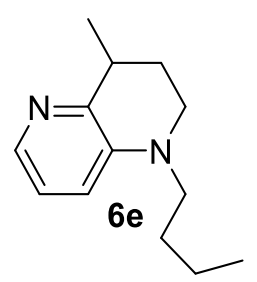

Compound $\mathbf{6 e}$ was synthesized from $\mathbf{5 f}$ according to the general procedure using $3.5 \mathrm{eq} \mathrm{SmI}_{2}$ and 14.0 eq TEU - at $-98{ }^{\circ} \mathrm{C}$ (entry 5 , Table 2$)$. The residue was purified by column chromatography $\left(\mathrm{SiO}_{2}\right.$, gradient ranging from $3 \%$ EtOAc in hexanes to $8 \%$ EtOAc in hexanes) to provide $49 \mathrm{mg}$ of the title compound $\mathbf{6 e}$ (84\%) as a colorless oil. HRMS (ESI) $m / z$ : $[\mathrm{M}+\mathrm{H}]^{+}$calcd for $\mathrm{C}_{13} \mathrm{H}_{21} \mathrm{~N}_{2}$ 205.1699; found 205.1693. IR (ATR) $\mathrm{cm}^{-1} 3048,2954,2929,2861,1577,1486,1446 .{ }^{1} \mathrm{H}$ NMR $\left(400 \mathrm{MHz} ; \mathrm{CDCl}_{3} \delta, \mathrm{ppm}\right) 7.82(\mathrm{dd}, J=$ 4.6, $0.9 \mathrm{~Hz}, 1 \mathrm{H}), 6.95(\mathrm{dd}, J=8.2,4.6 \mathrm{~Hz}, 1 \mathrm{H}), 6.82-6.78(\mathrm{~m}, 1 \mathrm{H}), 3.38-3.30(\mathrm{~m}, 1 \mathrm{H}), 3.29-3.15(\mathrm{~m}, 3 \mathrm{H})$, 3.07-2.97 (m, 1H), 2.13-2.03 (m, 1H), 1.82-1.74 (m, 1H), 1.61-1.52 (m, 2H), 1.43-1.32 (m, 2H), $1.36(\mathrm{~d}, J$ $=6.9 \mathrm{~Hz}, 3 \mathrm{H}), 0.98(\mathrm{t}, J=7.1 \mathrm{~Hz}, 3 \mathrm{H}) .{ }^{13} \mathrm{C} \mathrm{NMR}\left(100 \mathrm{MHz} ; \mathrm{CDCl}_{3} \delta, \mathrm{ppm}\right)$ 147.6, 141.0, 133.5, 121.9, $116.2,50.5,45.7,33.9,28.9,28.0,20.8,20.4,14.0$.

\section{4-Propyl-3,4-dihydro-2H-pyrano[3,2-b]pyridine (6f).}

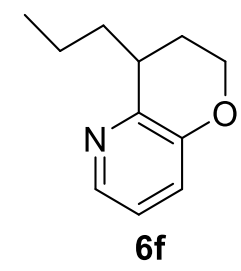

Compound $\mathbf{6} \mathbf{f}$ was synthesized from $\mathbf{5 h}$ according to the general procedure using $3.5 \mathrm{eq} \mathrm{SmI}_{2}$ and 7.0 eq TEU- at $-98{ }^{\circ} \mathrm{C}$ (entry 7 , Table 2$)$. The residue was purified by column chromatography $\left(\mathrm{SiO}_{2}\right.$, gradient ranging from $3 \%$ EtOAc in hexanes to $7 \%$ EtOAc in hexanes) to provide $27 \mathrm{mg}$ of the title compound $\mathbf{6 f}$ (54\%) as a colorless oil. HRMS (EI) $m / z$ : $\mathrm{M}^{+}$calcd for $\mathrm{C}_{11} \mathrm{H}_{15} \mathrm{ON} 177.1159$; found 177.1161. IR (ATR) 
$\mathrm{cm}^{-1} 2957,2871,1590,1572,1467,1440,1275 \mathrm{~cm}^{-1} .{ }^{1} \mathrm{H}$ NMR $\left(400 \mathrm{MHz} ; \mathrm{CDCl}_{3} \delta, \mathrm{ppm}\right) 8.16(\mathrm{dd}, J=$ 4.4, 1.6 Hz, 1H), 7.10-7.01 (m, 2H), 4.26-4.14 (m, 2H), 2.96-2.88 (m, 1H), 2.21-2.04 (m, 2H), 1.97-1.87 $(\mathrm{m}, 1 \mathrm{H}), 1.58-1.38(\mathrm{~m}, 3 \mathrm{H}), 0.99(\mathrm{t}, J=7.1 \mathrm{~Hz}, 3 \mathrm{H}) .{ }^{13} \mathrm{C} \mathrm{NMR}\left(100 \mathrm{MHz} ; \mathrm{CDCl}_{3} \delta, \mathrm{ppm}\right) 151.1,147.4$, $141.4,123.7,122.2,64.0,36.7,36.7,26.6,20.2,14.1$.

3-Isopropyl-2,3-dihydrofuro[3,2-b]quinolone (6g).

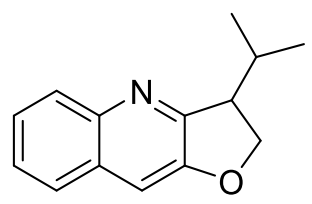

$6 \mathrm{~g}$

Compound $\mathbf{6 g}$ was synthesized from $\mathbf{5 i}$ according to the general procedure using $3.5 \mathrm{eq} \mathrm{SmI}_{2}$ and 7.0 eq TEU - at $-98{ }^{\circ} \mathrm{C}$ (entry 8 , Table 2$)$. The residue was purified by column chromatography $\left(\mathrm{SiO}_{2}\right.$, gradient ranging from $3 \%$ EtOAc in hexanes to $5 \%$ EtOAc in hexanes) to provide $51 \mathrm{mg}$ of the title compound $\mathbf{6 g}$ (84\%) as a colorless oil. HRMS (EI) m/z: $\mathrm{M}^{+}$calcd for $\mathrm{C}_{14} \mathrm{H}_{15} \mathrm{NO} 213.1159$; found 213.1166. IR (ATR) $\mathrm{cm}^{-1} 3060,2958,2928,1625,1388 .{ }^{1} \mathrm{H}$ NMR (400 MHz; $\left.\mathrm{CDCl}_{3} \delta, \mathrm{ppm}\right) 8.02(\mathrm{~d}, J=8.2 \mathrm{~Hz}, 1 \mathrm{H}), 7.70$ $(\mathrm{d}, J=7.8 \mathrm{~Hz}, 1 \mathrm{H}), 7.56-7.50(\mathrm{~m}, 1 \mathrm{H}), 7.49-7.44(\mathrm{~m}, 1 \mathrm{H}), 7.27(\mathrm{~d}, J=2.2 \mathrm{~Hz}, 1 \mathrm{H}), 4.77-4.70(\mathrm{~m}, 1 \mathrm{H})$, $4.60(\mathrm{dd}, J=9.2,5.5 \mathrm{~Hz}, 1 \mathrm{H}), 3.58-3.51(\mathrm{~m}, 1 \mathrm{H}), 2.48-2.36(\mathrm{~m}, 1 \mathrm{H}), 1.11(\mathrm{~d}, J=7.3 \mathrm{~Hz}, 3 \mathrm{H}), 0.90(\mathrm{~d}, J=$ $6.9 \mathrm{~Hz}, 3 \mathrm{H}) .{ }^{13} \mathrm{C} \mathrm{NMR}\left(100 \mathrm{MHz} ; \mathrm{CDCl}_{3} \delta, \mathrm{ppm}\right) 158.5,152.0,144.3,128.8,128.8,126.8,126.2,126.1$, 109.7, 72.8, 47.9, 31.1, 20.4, 17.7 .

\section{2-(Pent-4-enyloxy)naphthalene (7h).}

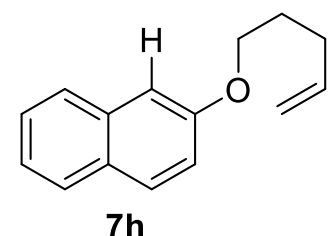

Compound $\mathbf{7 h}$ was synthesized from $\mathbf{5 j}$ according to the general procedure using $3.5 \mathrm{eq} \mathrm{SmI}_{2}$ and $14.0 \mathrm{eq}$ TEU- at $-98{ }^{\circ} \mathrm{C}$ (entry 9 , Table 2 ). The residue was purified by column chromatography $\left(\mathrm{SiO}_{2}, 1 \%\right.$ EtOAc in hexanes) to provide $40 \mathrm{mg}$ of the title compound $\mathbf{7 h}(66 \%)$ as a colorless oil. ${ }^{14}{ }^{1} \mathrm{H}$ NMR (400 MHz; $\left.\mathrm{CDCl}_{3} \delta, \mathrm{ppm}\right)$ 7.82-7.71 (m, 3H), 7.50-7.42 (m, 1H), 7.39-7.13 (m, 1H), 7.15 (m, 2H), 5.98-5.85 (m, 
1H), 5.16-5.08 (m, 1H), 5.08-5.01 (m, 1H), $4.12(\mathrm{t}, J=6.4 \mathrm{~Hz}, 2 \mathrm{H}), 2.36-2.27(\mathrm{~m}, 2 \mathrm{H}), 2.03-1.93(\mathrm{~m}$, 2H). NMR (100 MHz; $\mathrm{CDCl}_{3} \delta$, ppm) 156.9, 137.8, 134.5, 129.3, 128.8, 127.6, 126.7, 126.3, 123.5, $119.0,115.2,106.5,67.1,30.2,28.4$.

5-(4-Methoxyphenyl)-6-chloro-1-hexene (8a).

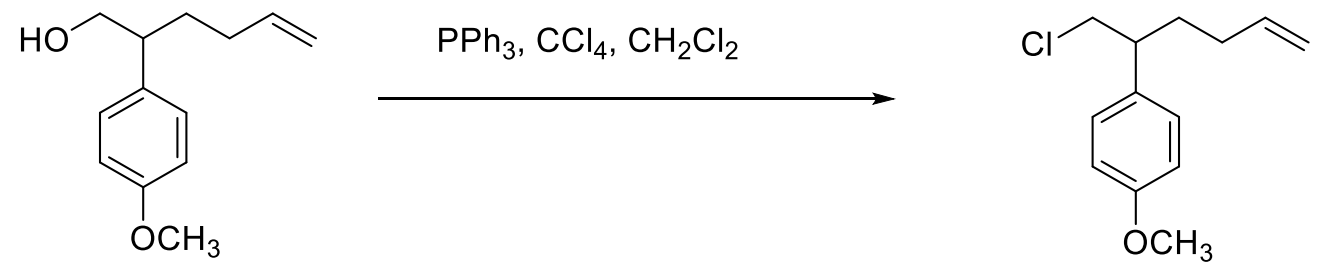

$8 \mathbf{a}$

$\mathrm{CH}_{2} \mathrm{Cl}_{2}(8.1 \mathrm{~mL})$ and triphenylphosphine (1.40 g, $\left.5.34 \mathrm{mmol}\right)$ were added to 2-(4-methoxyphenyl)-5hexen-1-ol (1.00 g, $4.85 \mathrm{mmol}) . \mathrm{CCl}_{4}(516 \mu \mathrm{L}, 5.4 \mathrm{mmol})$ was added and the mixture was allowed to stir at $\mathrm{rt}$ overnight. Water $(10 \mathrm{~mL})$ was added and the mixture was extracted with hexanes $(3 \mathrm{X} 10 \mathrm{~mL})$. The combined organic layers were concentrated under reduced pressure. The residue was purified by column chromatography $\left(\mathrm{SiO}_{2}, 1 \%\right.$ EtOAc in hexanes) to provide $860 \mathrm{mg}$ of the title compound $\mathbf{8 a}(79 \%)$ as a colorless oil. HRMS (ESI) $m / z$ : [M + Na $]^{+}$calcd for $\mathrm{C}_{13} \mathrm{H}_{17} \mathrm{ClNaO} 247.0860$; found 247.0857. IR (ATR) $\mathrm{cm}^{-1} 3076,2998,2934,2836,1640,1610,1583,1511 .{ }^{1} \mathrm{H} \mathrm{NMR}\left(400 \mathrm{MHz} ; \mathrm{CDCl}_{3} \delta, \mathrm{ppm}\right) .7 .13(\mathrm{~d}, J=$ $8.2 \mathrm{~Hz}, 2 \mathrm{H}), 6.89(\mathrm{~d}, J=8.2 \mathrm{~Hz}, 2 \mathrm{H}), 5.84-5.73(\mathrm{~m}, 1 \mathrm{H}), 5.01-4.96(\mathrm{~m}, 1 \mathrm{H}), 4.97-4.94(\mathrm{~m}, 1 \mathrm{H}), 3.82(\mathrm{~s}$, $3 \mathrm{H}), 3.66(\mathrm{~d}, J=6.9 \mathrm{~Hz}, 2 \mathrm{H}), 2.95-2.87(\mathrm{~m}, 1 \mathrm{H}), 2.06-1.87(\mathrm{~m}, 3 \mathrm{H}), 1.75-1.64(\mathrm{~m}, 1 \mathrm{H}) .{ }^{13} \mathrm{C} \mathrm{NMR}(100$ $\left.\mathrm{MHz} ; \mathrm{CDCl}_{3} \delta, \mathrm{ppm}\right) 158.5,137.9,133.6,128.7,115.0,113.9,55.2,49.9,46.6,32.2,31.2$.

\section{3-(2-Allylphenyl)-2-fluoropyridine (8c).}
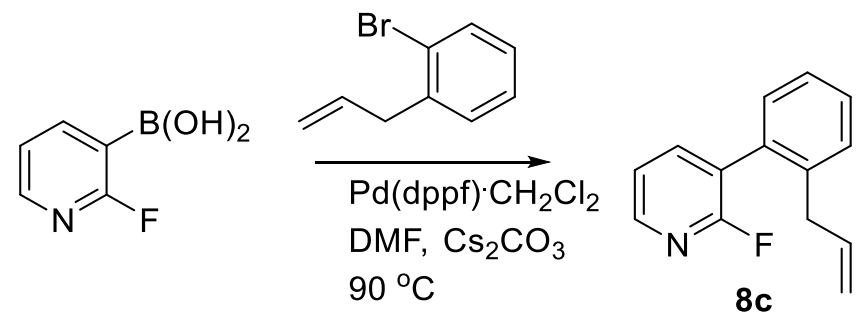

Using the method of Bailey, ${ }^{15} \mathrm{DMF}(20.4 \mathrm{~mL})$ was added to 2-bromoallylbenzene (603 $\mathrm{mg}, 3.06 \mathrm{mmol}$ ), $\mathrm{Pd}(\mathrm{dppf}) \mathrm{Cl}_{2} \cdot \mathrm{CH}_{2} \mathrm{Cl}_{2}(250 \mathrm{mg}, 0.306 \mathrm{mmol}), \mathrm{Cs}_{2} \mathrm{CO}_{3}(1.50 \mathrm{~g}, 4.60 \mathrm{mmol})$, and 2-fluoro-3-pyridineboronic 
acid (561 mg, $3.98 \mathrm{mmol}$ ). The mixture was evacuated and backfilled three times with argon then heated to $90{ }^{\circ} \mathrm{C}$ with a digital hotplate stirrer for $90 \mathrm{~min}$. After cooling the mixture was added to water $(100 \mathrm{~mL})$ and extracted with $\mathrm{Et}_{2} \mathrm{O}(3 \times 75 \mathrm{~mL})$. The combined organic extracts were washed with water $(50 \mathrm{~mL})$, brine $(50 \mathrm{~mL})$, and the solvent was removed under reduced pressure. The residue was purified by column chromatography $\left(\mathrm{SiO}_{2}\right.$, gradient ranging from 3\% EtOAc in hexanes to 5\% EtOAc in hexanes) to provide $510 \mathrm{mg}$ of the title compound $\mathbf{8 c}(78 \%)$ as a colorless oil. HRMS (ESI) $m / z:[\mathrm{M}+\mathrm{Na}]^{+}$calcd for $\mathrm{C}_{14} \mathrm{H}_{12} \mathrm{FNNa} 236.0846$; found 236.0843. IR (ATR) $\mathrm{cm}^{-1} 3059,2979,1638,1599,1566,1427,1416 .{ }^{1} \mathrm{H}$ NMR (400 MHz; $\left.\mathrm{CDCl}_{3} \delta, \mathrm{ppm}\right)$ 8.28-8.24 (m, 1H), 7.74-7.68 (m, 1H), 7.44-7.37 (m, 1H), 7.37-7.39 (m, 1H), 7.38-7.34 (m, 1H), 7.32-7.26 (m, 1H), 7.24 (d, J=7.3 Hz, 1H), 5.89-5.77 (m, 1H), $5.00(\mathrm{dd}, J=$ 10.0, 1.4 Hz, 1H), $4.87(\mathrm{dd}, J=17.4,1.4 \mathrm{~Hz}, 1 \mathrm{H}), 3.29(\mathrm{~d}, J=6.4 \mathrm{~Hz}, 2 \mathrm{H}) .{ }^{13} \mathrm{C} \mathrm{NMR}\left(100 \mathrm{MHz} ; \mathrm{CDCl}_{3}\right.$ $\delta$, ppm) $160.4(\mathrm{~d}, J=241.5 \mathrm{~Hz}), 146.8(\mathrm{~d}, J=14.5 \mathrm{~Hz}), 142.0(\mathrm{~d}, J=4.8 \mathrm{~Hz}), 138.3,136.5,133.5(\mathrm{~d}, J=$ $3.9 \mathrm{~Hz}), 130.2,129.7,128.8,126.4,123.6(\mathrm{~d}, J=31.8 \mathrm{~Hz}), 121.2(\mathrm{~d}, J=4.8 \mathrm{~Hz}), 116.1,37.5$.

\section{2-Allyl-3-(2-chlorophenyl)pyridine (8d).}

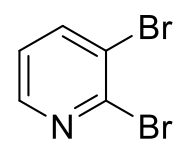

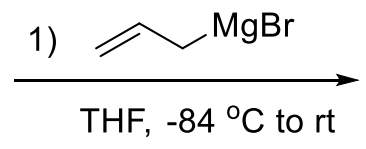

2) $\mathrm{H}_{2} \mathrm{O}$

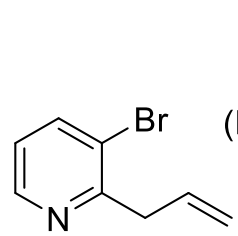

SI-1

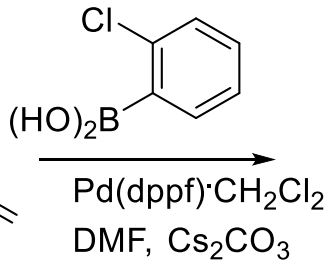

$90^{\circ} \mathrm{C}$

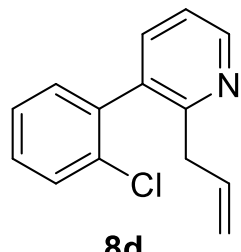

8d

THF (4.0 mL) was added to 2,3-dibromopyridine $(500 \mathrm{mg}, 2.11 \mathrm{mmol})$ and the mixture was cooled to

$-84^{\circ} \mathrm{C}$. A $2.0 \mathrm{M}$ solution of allylmagnesium bromide $(1.11 \mathrm{~mL}, 2.2 \mathrm{mmol})$ was added over 3 min with stirring. ${ }^{16}$ The mixture was allowed to warm to rt overnight. Water $(5 \mathrm{~mL})$ was added and the mixture was extracted with $\mathrm{Et}_{2} \mathrm{O}(3 \mathrm{X} 5 \mathrm{~mL})$, dried over $\mathrm{Na}_{2} \mathrm{SO}_{4}$, then concentrated under reduced pressure to provide $793 \mathrm{mg}$ of 2-allyl-3-bromopyridine (SI-1) as a colorless oil (94\% crude yield). ${ }^{1} \mathrm{H}$ and ${ }^{13} \mathrm{C}$ NMR were in accord with literature spectra. ${ }^{17}$ Using the method of Bailey, ${ }^{15} \mathrm{DMF}(26.0 \mathrm{~mL})$ was added to SI-1 (763 mg, $4.01 \mathrm{mmol}), \mathrm{Pd}(\mathrm{dppf}) \mathrm{Cl}_{2} \cdot \mathrm{CH}_{2} \mathrm{Cl}_{2}(327 \mathrm{mg}, 0.401 \mathrm{mmol}), \mathrm{Cs}_{2} \mathrm{CO}_{3}(1.96 \mathrm{~g}, 6.01 \mathrm{mmol})$, and 2chlorophenylboronic acid $(627 \mathrm{mg}, 4.01 \mathrm{mmol})$. The mixture was evacuated and backfilled three times 
with argon then heated to $90{ }^{\circ} \mathrm{C}$ with a digital hotplate stirrer for 90 min. After cooling the mixture was added to water $(100 \mathrm{~mL})$ and extracted with $\mathrm{Et}_{2} \mathrm{O}(3 \mathrm{X} 75 \mathrm{~mL})$. The combined organic extracts were washed with water $(50 \mathrm{~mL})$, brine $(50 \mathrm{~mL})$, and the solvent was removed under reduced pressure. The residue was purified by column chromatography $\left(\mathrm{SiO}_{2}\right.$, gradient ranging from $1.5 \%$ EtOAc in hexanes to 4\% EtOAc in hexanes) to provide $512 \mathrm{mg}$ of the title compound $\mathbf{8 d}(56 \%)$ as a pale-yellow oil. HRMS (ESI) $\mathrm{m} / z:[\mathrm{M}+\mathrm{H}]^{+}$calcd for $\mathrm{C}_{14} \mathrm{H}_{13} \mathrm{ClN} 230.0731$; found 230.0727. IR (ATR) $\mathrm{cm}^{-1} 3052,2987,1638$, 1566, 1479, 1423. ${ }^{1} \mathrm{H}$ NMR (400 MHz; $\mathrm{CDCl}_{3} \delta$, ppm) $8.64(\mathrm{dd}, J=5.0,1.4 \mathrm{~Hz}, 1 \mathrm{H}), 7.54-7.47$ (m, 2H), 7.40-7.31 (m, 2H), 7.27-7.21 (m, 2H), 6.02-5.90 (m, 1H), 5.02 (dd, $J=10.1,1.4 \mathrm{~Hz}, 1 \mathrm{H}), 4.91(\mathrm{dd}, J=$ 16.9, $1.4 \mathrm{~Hz}, 1 \mathrm{H}), 3.53-3.45(\mathrm{~m}, 1 \mathrm{H}), 3.41-3.32(\mathrm{~m}, 1 \mathrm{H}) .{ }^{13} \mathrm{C} \mathrm{NMR}\left(100 \mathrm{MHz} ; \mathrm{CDCl}_{3} \delta, \mathrm{ppm}\right) 157.6$, 149.0, 138.0, 137.7, 135.4, 134.3, 133.3, 131.2, 129.6, 129.3, 126.7, 121.0, 116.3, 40.3.

\section{3-(3-Chloropropyl)-3-[(2-ethoxymethoxy)methylcyclopentene (8e).}<smiles>COC(=O)C1(CCCO[Sb])C=CCC1</smiles>

1) $\mathrm{LiAlH}_{4}, \mathrm{THF}, 0^{\circ} \mathrm{C}$

2) $\mathrm{H}_{2} \mathrm{O}$

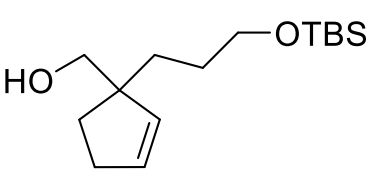

SI-2

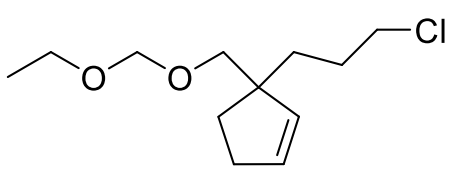

$8 e$
1) $\mathrm{O} \mathrm{O} \smile \mathrm{Cl}$ DIPEA, $\mathrm{CH}_{2} \mathrm{Cl}_{2}$ $0^{\circ} \mathrm{C}$ to rt
2) $\mathrm{F}^{-}, \mathrm{THF}$
3) $\mathrm{TsCl}$, pyridine, $n-\mathrm{Bu}_{4} \mathrm{NCl}$

$\mathrm{LiAlH}_{4}(92 \mathrm{mg}, 2.41 \mathrm{mmol})$ was added to THF $(15 \mathrm{~mL})$ at $0{ }^{\circ} \mathrm{C}$. A solution of methyl 3-(3-tertbutyldimethylsiloxypropyl) cyclopentene-3-carboxylate $(1.20 \mathrm{~g}, 4.03 \mathrm{mmol})$ in THF (5 mL) was added over 5 min. This mixture was allowed to stir for $2 \mathrm{~h}$ at $0{ }^{\circ} \mathrm{C}$. Water $(77 \mu \mathrm{L}), 15 \% \mathrm{NaOH}_{(\mathrm{aq})}(77 \mu \mathrm{L})$, and water $(230 \mu \mathrm{L})$ were added sequentially. The mixture was filtered, the solid being rinsed with $\mathrm{Et}_{2} \mathrm{O}$. The filtrate was concentrated under reduced pressure. The residue was purified by column chromatography $\left(\mathrm{SiO}_{2}\right.$, gradient ranging from 3\% EtOAc in hexanes to $15 \%$ EtOAc in hexanes) to provide $990 \mathrm{mg}$ of 3-(3- 
tert-butyldimethylsiloxy)-3-hydroxymethylcyclopentene (SI-2) as a colorless oil (91\%). HRMS (ESI) $m / z:[\mathrm{M}+\mathrm{Na}]^{+}$calcd for $\mathrm{C}_{15} \mathrm{H}_{30} \mathrm{NaO}_{2} \mathrm{Si}, 293.1907$; found 293.1924. IR (ATR) $\mathrm{cm}^{-1} 3381,3049,2929$, 2896, 2856, 1471. ${ }^{1} \mathrm{H}$ NMR (400 MHz; $\mathrm{CDCl}_{3} \delta$, ppm) 5.88-5.83 (m, 1H), 5.48-5.42 (m, 1H), 3.64-3.55 (m, 2H), 3.51-3.40 (m, 2H), 2.42-2.33 (m, 2H), 1.90-1.79 (m, 1H), 1.73-1.61 (m, 1H), 1.56-1.38 (m, 5H), 0.90 (s, 9H), 0.06 (s, 6H). ${ }^{13} \mathrm{C} \mathrm{NMR}\left(100 \mathrm{MHz} ; \mathrm{CDCl}_{3} \delta, \mathrm{ppm}\right) 134.8,133.0,69.2,63.8,54.7,32.5,32.4$, $31.0,27.8,26.0,18.4,-5.3$.

$\mathrm{CH}_{2} \mathrm{Cl}_{2}(4.5 \mathrm{~mL})$ was added to alcohol SI-2 $(982 \mathrm{mg}, 3.63 \mathrm{mmol})$ and the mixture was cooled to $0{ }^{\circ} \mathrm{C}$ with stirring. DIPEA (1.65 mL, $9.44 \mathrm{mmol})$ and chloromethylethyl ether (439 $\mu \mathrm{L}, 4.72 \mathrm{mmol})$ were added and the mixture was allowed to warm to rt overnight. Water $(10 \mathrm{~mL})$ was added and the mixture was extracted with hexanes $(3 \mathrm{X} 10 \mathrm{~mL})$. The combined organic extracts were dried with $\mathrm{Na}_{2} \mathrm{SO}_{4}$, filtered, and the solvent was removed under reduced pressure to provide $817 \mathrm{mg}$ of the crude ethoxymethyl ether as a pale-yellow oil. THF $(6.2 \mathrm{~mL})$ was added to the ether, the mixture was cooled to $0{ }^{\circ} \mathrm{C}$, and $3.0 \mathrm{~mL}$ of a 1.0 M solution of $\left(n-\mathrm{Bu}_{4}\right) \mathrm{NF}(3.0 \mathrm{mmol})$ was added. This mixture allowed to warm to rt while stirring overnight. Water $(10 \mathrm{~mL})$ and $\mathrm{NaCl}(3.0 \mathrm{~g})$ were added and the mixture was extracted with $\mathrm{Et}_{2} \mathrm{O}(3 \mathrm{X} 15$ $\mathrm{mL}$ ). The combined extracts were dried with $\mathrm{Na}_{2} \mathrm{SO}_{4}$, filtered, and concentrated under reduced pressure to afford $480 \mathrm{mg}$ of the desilylated alcohol as a yellow viscous oil. Pyridine $(1.3 \mathrm{~mL})$ was added to the alcohol and the mixture was cooled to $0{ }^{\circ} \mathrm{C}$ with stirring. Tosyl chloride (412 $\mathrm{mg}, 2.16 \mathrm{mmol}$ ) was added and the mixture was stirred for $2 \mathrm{~h}$ and allowed to warm to rt. $\left(n-\mathrm{Bu}_{4}\right) \mathrm{NCl}(424 \mathrm{mg}, 1.52 \mathrm{mmol})$ was added and the mixture was stirred overnight. $\mathrm{H}_{2} \mathrm{O}(10 \mathrm{~mL}$ was added and the mixture was extracted with hexanes ( 3 X $10 \mathrm{~mL}$ ) and concentrated under reduced pressure. The residue was purified by column chromatography $\left(\mathrm{SiO}_{2}\right.$, gradient ranging from 1\% EtOAc in hexanes to 3\% EtOAc in hexanes) to provide $256 \mathrm{mg}$ of the title compound $\mathbf{8 e}$ as a colorless oil (30\% from SI-2). HRMS (ESI) $m / z:\left[\mathrm{M}-\mathrm{OC}_{2} \mathrm{H}_{5}\right]^{+}$ calcd for $\mathrm{C}_{10} \mathrm{H}_{16} \mathrm{ClO} 187.0834$; found 187.0833. (ATR) $\mathrm{cm}^{-1} 3050,2931,2853,1445,1390,1284 .{ }^{1} \mathrm{H}$ NMR (400 MHz; $\left.\mathrm{CDCl}_{3} \delta, \mathrm{ppm}\right)$ 5.80-5.76 (m, 1H), 5.55-5.50 (m, 1H), $4.68(\mathrm{~s}, 2 \mathrm{H}), 3.60(\mathrm{q}, J=6.9 \mathrm{~Hz}$ 2H), $3.53(\mathrm{t}, J=6.4 \mathrm{~Hz}, 2 \mathrm{H}), 3.39(\mathrm{~s}, 2 \mathrm{H}), 2.42-2.33(\mathrm{~m}, 2 \mathrm{H}), 1.83-1.71(\mathrm{~m}, 3 \mathrm{H}), 1.71-1.55(\mathrm{~m}, 3 \mathrm{H}), 1.23$ 
$(\mathrm{t}, J=7.3 \mathrm{~Hz}, 3 \mathrm{H}) .{ }^{13} \mathrm{C} \mathrm{NMR}\left(100 \mathrm{MHz} ; \mathrm{CDCl}_{3} \delta, \mathrm{ppm}\right) 135.3,131.6,95.3,74.2,63.1,52.8,45.8,34.0$,

31.9, 31.6, 28.1, 15.1 .

3-(4-Chlorobutyl)]-3-[(2-ethoxymethoxy)methylcyclopentene (8f).
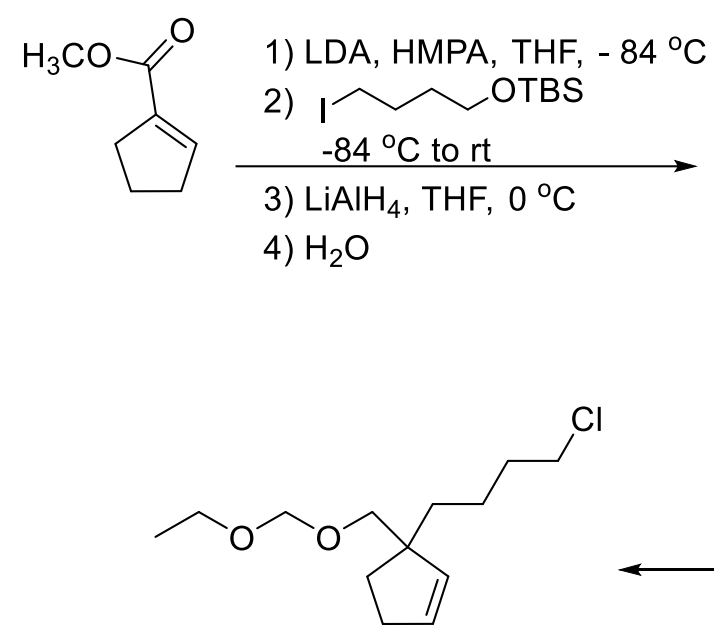

$8 f$

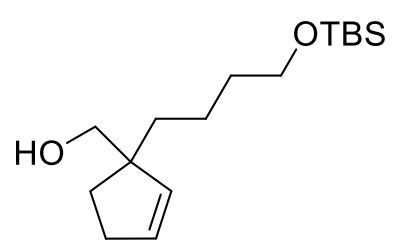

SI-3

1) $\mathrm{O}^{\mathrm{O}} \sim \mathrm{Cl}$

DIPEA, $\mathrm{CH}_{2} \mathrm{Cl}_{2}$

$0{ }^{\circ} \mathrm{C}$ to $\mathrm{rt}$

2) $\mathrm{F}^{-}, \mathrm{THF}$

3) $\mathrm{TsCl}$, pyridine, $(n-\mathrm{NBu})_{4} \mathrm{NCl}$

Using a modified version of Alexinian's procedure, ${ }^{11} \mathrm{THF}(11.4 \mathrm{~mL})$ was added to $i-\mathrm{Pr}_{2} \mathrm{NH}(1.51 \mathrm{~mL}$, $10.8 \mathrm{mmol})$ and the mixture was cooled to $-84^{\circ} \mathrm{C}$. A solution $2.5 \mathrm{M} n$-BuLi in hexanes $(4.0 \mathrm{~mL}, 10$ mmol) was added and the mixture was stirred for $5 \mathrm{~min}$ at $-84^{\circ} \mathrm{C}$. HMPA (4.0 mL, $0.023 \mathrm{~mol}$ ) was added and the mixture was stirred for $30 \mathrm{~min}$ at $-84^{\circ} \mathrm{C}$. A solution of methyl 1-cyclopentene-1-carboxylate $(0.97 \mathrm{~g}, 7.7 \mathrm{mmol})$ in THF $(2.0 \mathrm{~mL})$ was added over $10 \mathrm{~min}$. The resultant mixture was stirred for $30 \mathrm{~min}$ at $-84{ }^{\circ} \mathrm{C}$. A solution of 4-tert-butyl-dimethylsiloxy-1-iodobutane $(3.63 \mathrm{~g}, 0.0116 \mathrm{~mol})$ in $\mathrm{THF}(2.0 \mathrm{~mL})$ was added, and the mixture was allowed to warm to rt overnight. Half saturated $\mathrm{NH}_{4} \mathrm{Cl}_{(\mathrm{aq})}(20 \mathrm{~mL})$ was added and the mixture was extracted with hexanes $(3 \mathrm{X} 20 \mathrm{~mL}$ ). The combined organic extracts were washed with water $(2 \mathrm{X} 10 \mathrm{~mL})$, dried over $\mathrm{Na}_{2} \mathrm{SO}_{4}$, filtered, and the solvent was removed under reduced pressure to provide the crude alkylated product. $\mathrm{LiAlH}_{4}(146 \mathrm{mg}, 3.85 \mathrm{mmol})$ was added to THF (33 mL) at $0{ }^{\circ} \mathrm{C}$. A solution of the crude methyl 3-(4-tert-butyldimethylsiloxybutyl) cyclopentene-3-carboxylate in THF $(5 \mathrm{~mL})$ was added over $5 \mathrm{~min}$. This mixture was allowed to stir for $2 \mathrm{~h}$ at $0{ }^{\circ} \mathrm{C}$. Water $(146 \mu \mathrm{L})$, $15 \% \mathrm{NaOH}_{(\mathrm{aq})}(146 \mu \mathrm{L})$, and water $(440 \mu \mathrm{L})$ were added sequentially. The mixture was filtered, the solid 
being rinsed with $\mathrm{Et}_{2} \mathrm{O}$. The filtrate was concentrated under reduced pressure. The residue was purified by column chromatography $\left(\mathrm{SiO}_{2}\right.$, gradient ranging from $3 \%$ EtOAc in hexanes to $15 \%$ EtOAc in hexanes) to provide $1.29 \mathrm{~g}$ of 3-(3-tert-butyldimethylsiloxybutyl)-3-hydroxymethylcyclopentene (SI-3) as a colorless oil (58\% from methyl 1-cyclopentene-1-carboxylate). (HRMS (ESI) $m / z:[\mathrm{M}+\mathrm{Na}]^{+}$calcd for $\mathrm{C}_{16} \mathrm{H}_{32} \mathrm{NaO}_{2} \mathrm{Si}$, 307.2064; found 307.2072. IR (ATR) $\mathrm{cm}^{-1} 3358,3048,2929$, 2897, 2856, 1471, 1461, 1388. ${ }^{1} \mathrm{H}$ NMR (400 MHz; $\left.\mathrm{CDCl}_{3} \delta, \mathrm{ppm}\right) 5.89-5.82(\mathrm{~m}, 1 \mathrm{H}), 5.47-5.41(\mathrm{~m}, 1 \mathrm{H}), 3.61(\mathrm{t}, J=6.4 \mathrm{~Hz}, 2 \mathrm{H})$, 3.51-3.46 (m, 1H), 3.46-3.37 (m, 1H), 2.42-2.33 (m, 2H), 1.85-1.77 (m, 1H), 1.69-1.63 (m, 1H), 1.55$1.46(\mathrm{~m}, 2 \mathrm{H}), 1.46-1.32(\mathrm{~m}, 3 \mathrm{H}), 1.32-1.21(\mathrm{~m}, 2 \mathrm{H}), 0.90(\mathrm{~s}, 9 \mathrm{H}), 0.06(\mathrm{~s}, 6 \mathrm{H}) .{ }^{13} \mathrm{C} \mathrm{NMR}(100 \mathrm{MHz}$ $\left.\mathrm{CDCl}_{3} \delta, \mathrm{ppm}\right) 134.8,133.0,69.3,63.0,55.0,36.2,33.5,32.5,30.9,25.9,20.7,18.3,-5.3$.

$\mathrm{CH}_{2} \mathrm{Cl}_{2}(5.4 \mathrm{~mL})$ was added to alcohol $\mathbf{S I - 3}(1.23 \mathrm{~g}, 4.33 \mathrm{mmol})$ and the mixture was cooled to $0{ }^{\circ} \mathrm{C}$ with stirring. DIPEA $(1.96 \mathrm{~mL}, 0.0113 \mathrm{~mol})$ and chloromethylethyl ether $(522 \mu \mathrm{L}, 5.63 \mathrm{mmol})$ were added and the mixture was allowed to warm to rt overnight. Water $(10 \mathrm{~mL})$ was added and the mixture was extracted with hexanes $(3 \mathrm{X} 10 \mathrm{~mL})$. The combined organic extracts were dried with $\mathrm{Na}_{2} \mathrm{SO}_{4}$, filtered, and the solvent was removed under reduced pressure to provide $1.36 \mathrm{~g}$ of the crude ethoxymethyl ether as a pale-yellow oil. THF $(10.0 \mathrm{~mL})$ was added to the ether, the mixture was cooled to $0{ }^{\circ} \mathrm{C}$, and $4.8 \mathrm{~mL}$ of a 1.0 M solution of $(n-\mathrm{Bu})_{4} \mathrm{NF}(4.8 \mathrm{mmol})$ was added. This mixture allowed to warm to rt while stirring overnight. Water $(15 \mathrm{~mL})$ and $\mathrm{NaCl}(4.0 \mathrm{~g})$ were added and the mixture was extracted with $\mathrm{Et}_{2} \mathrm{O}(3 \mathrm{X} 20$ $\mathrm{mL}$ ). The combined extracts were dried with $\mathrm{Na}_{2} \mathrm{SO}_{4}$, filtered, and concentrated under reduced pressure to afford $808 \mathrm{mg}$ of the crude desilylated alcohol as a yellow viscous oil. Pyridine $(5.2 \mathrm{~mL})$ was added to the alcohol and the mixture was cooled to $0{ }^{\circ} \mathrm{C}$ with stirring. Tosyl chloride $(1.40 \mathrm{~g}, 7.36 \mathrm{mmol})$ was added and the mixture was stirred for $2 \mathrm{~h}$ and allowed to warm to rt. $n-\mathrm{Bu}_{4} \mathrm{NCl}(1.44 \mathrm{~g}, 5.20 \mathrm{mmol})$ was added and the mixture was stirred overnight. $\mathrm{H}_{2} \mathrm{O}(15 \mathrm{~mL}$ was added and the mixture was extracted with hexanes ( 3 X $15 \mathrm{~mL}$ ) and concentrated under reduced pressure. The residue was purified by column chromatography $\left(\mathrm{SiO}_{2}\right.$, gradient ranging from 1\% EtOAc in hexanes to 3\% EtOAc in hexanes) to provide $470 \mathrm{mg}$ of the title compound $\mathbf{8 f}$ as a colorless oil (44\% from SI-3). HRMS (ESI) $m / z:\left[\mathrm{M}-\mathrm{OC}_{2} \mathrm{H}_{5}\right]^{+}$ 
calcd for $\mathrm{C}_{11} \mathrm{H}_{18} \mathrm{ClO} 201.1040$; found 201.1036. IR (ATR) $\mathrm{cm}^{-1} 3049,2935,2851,1457,1380,1290 .{ }^{1} \mathrm{H}$ NMR (400 MHz; $\mathrm{CDCl}_{3} \delta$, ppm) 5.79-5.74 (m, 1H), 5.55-5.51 (m, 1H), $4.69(\mathrm{~s}, 2 \mathrm{H}), 3.64-3.57(\mathrm{~m}, 2 \mathrm{H})$, 3.57-3.52 (m, 2H), 3.41-3.37 (m, 2H), 2.40-2.32 (m, 2H), 1.82-1.74 (m, 3H), 1.70-1.61 (m, 1H), 1.51$1.34(\mathrm{~m}, 4 \mathrm{H}), 1.23(\mathrm{t}, J=7.3 \mathrm{~Hz}, 3 \mathrm{H}) .{ }^{13} \mathrm{C} \mathrm{NMR}\left(100 \mathrm{MHz} ; \mathrm{CDCl}_{3} \delta, \mathrm{ppm}\right) 135.6,131.3,95.4,74.2,63.1$, $53.1,45.1,35.9,33.3,31.9,31.7,21.9,15.1$.

\section{Phenyl 3-(3-chloropropyl)methylcyclopentene carbamate (8g).}

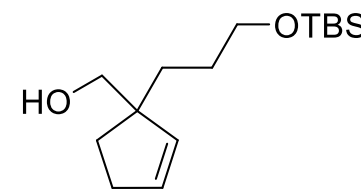

SI-2
1) $\mathrm{PhNCO}$, pyridine, DMAP

2) $\mathrm{F}^{-}, \mathrm{THF}$

3) $\mathrm{TsCl}$, pyridine, $(n-\mathrm{Bu})_{4} \mathrm{NCl}$

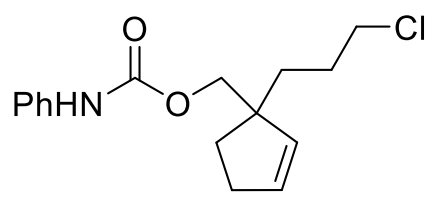

$8 \mathrm{~g}$

Pyridine $(3.2 \mathrm{~mL})$ was added to alcohol SI-2 $(858 \mathrm{mg}, 3.18 \mathrm{mmol})$ and the mixture was cooled to $0{ }^{\circ} \mathrm{C}$ with stirring. DMAP (15 mg) was added followed by $0.49 \mathrm{~mL}(4.1 \mathrm{mmol})$ phenyl isocyanate and the mixture was allowed to warm to $\mathrm{rt}$ and stir overnight. Water $(10 \mathrm{~mL})$ was added and the mixture was extracted with ether $(3 \times 15 \mathrm{~mL})$. The combined organic extracts were dried with $\mathrm{Na}_{2} \mathrm{SO}_{4}$, filtered, and the solvent was removed under reduced pressure to provide $1.19 \mathrm{~g}$ of the crude phenyl carbamate as a viscous yellow oil. THF $(10.0 \mathrm{~mL})$ was added to the carbamate, the mixture was cooled to $0{ }^{\circ} \mathrm{C}$, and 4.0 $\mathrm{mL}$ of a $1.0 \mathrm{M}$ solution of $(n-\mathrm{Bu})_{4} \mathrm{NF}(4.0 \mathrm{mmol})$ was added. This mixture allowed to warm to rt while stirring overnight. Water $(15 \mathrm{~mL})$ and $\mathrm{NaCl}(4.0 \mathrm{~g})$ were added and the mixture was extracted with $\mathrm{Et}_{2} \mathrm{O}$ ( 3 X $20 \mathrm{~mL}$ ). The combined extracts were dried with $\mathrm{Na}_{2} \mathrm{SO}_{4}$, filtered, and concentrated under reduced pressure to afford $763 \mathrm{mg}$ of the crude desilylated alcohol as a yellow viscous oil. Pyridine $(2.8 \mathrm{~mL})$ was added to the alcohol and the mixture was cooled to $0{ }^{\circ} \mathrm{C}$ with stirring. Tosyl chloride $(689 \mathrm{mg}, 3.61$ mmol) was added and the mixture was stirred for $2 \mathrm{~h}$ and allowed to warm to rt. $n$ - $\mathrm{Bu}{ }_{4} \mathrm{NCl}$ (773 mg, 2.78 mmol) was added and the mixture was stirred overnight. $\mathrm{H}_{2} \mathrm{O}(15 \mathrm{~mL})$ was added and the mixture was extracted with hexanes ( 3 X $15 \mathrm{~mL}$ ) and concentrated under reduced pressure. The residue was purified by column chromatography $\left(\mathrm{SiO}_{2}, 5 \%\right.$ EtOAc in hexanes) to provide $586 \mathrm{mg}$ of the title compound $\mathbf{8 g}$ as 
a colorless viscous oil (62\% from SI-2). HRMS (ESI) $m / z$ : $[\mathrm{M}+\mathrm{H}]^{+}$calcd for $\mathrm{C}_{16} \mathrm{H}_{21} \mathrm{ClNO}_{2} 294.1255$, found 294.1280. IR (ATR) $\mathrm{cm}^{-1} 3322,3051,2947,2851,1705,1599,1525,1501 .{ }^{1} \mathrm{H}$ NMR (400 MHz; $\left.\mathrm{CDCl}_{3} \delta, \mathrm{ppm}\right)$ 7.44-7.37 (m, 2H), 7.36-7.29 (m, 2H), 7.12-7.06 (m, 1H), 6.68-6.60 (b, 1H), 5.86-5.82 (m, 1H), 5.54-5.50 (m, 1H), $4.09(\mathrm{~d}, J=10.5 \mathrm{~Hz}, 1 \mathrm{H}), 4.03(\mathrm{~d}, J=10.5 \mathrm{~Hz}, 1 \mathrm{H}), 3.55(\mathrm{t}, J=6.4 \mathrm{~Hz}, 2 \mathrm{H})$, 2.48-2.32 (m, 2H), 1.89-1.66 (m, 4H), 1.65-1.59 (m, 2H). $\left.{ }^{13} \mathrm{C} \mathrm{NMR} \mathrm{(100} \mathrm{MHz;} \mathrm{CDCl}_{3} \delta, \mathrm{ppm}\right)$ 153.6, $137.8,134.2,132.6,129.0,123.4,118.6,70.7,52.4,45.6,33.8,32.0,31.4,27.9$.

\section{$N, N$-Dibutyl 3-(3-chloropropyl)cyclopentene-3-carboxamide (8h).}

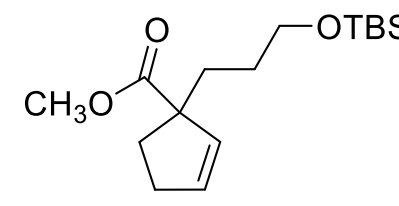

1) BuS-, HMPA
2) $\mathrm{EDC}, \mathrm{Bu}_{2} \mathrm{NH}, \mathrm{Et}_{3} \mathrm{~N}$ $\mathrm{CH}_{2} \mathrm{Cl}_{2}$

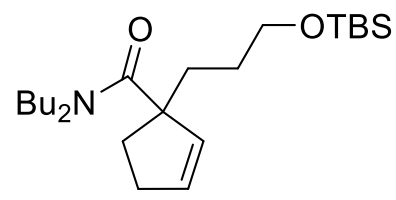

SI-4

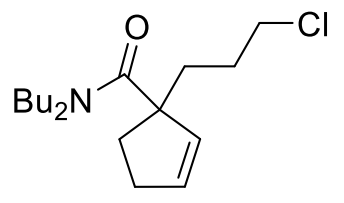

1) $\mathrm{F}^{-}, \mathrm{THF}$

2) $\mathrm{TsCl}$, pyridine, $(n-\mathrm{Bu})_{4} \mathrm{NCl}$

$8 h$

Using the procedure of Bartlett, ${ }^{18}$ degassed HMPA $(3.0 \mathrm{~mL})$ was added to a round bottom flask and cooled to $0{ }^{\circ} \mathrm{C}$. $n$-Propanethiol $(1.23 \mathrm{~mL}, 0.0133 \mathrm{~mol})$ was added followed by the slow addition of a solution of $2.5 \mathrm{M} \mathrm{n}$-BuLi (5.0 mL, $0.013 \mathrm{mmol})$. This mixture was allowed to stir for $15 \mathrm{~min}$, then a solution of methyl 3-(3-tert-butyldimethylsiloxypropyl) cyclopentene-3-carboxylate (1.07 g, 0.00359 mol) in $1.0 \mathrm{~mL}$ of HMPA was added, and the mixture was allowed to warm to rt over $4 \mathrm{~h}$. Sufficient $10 \%$ $\mathrm{HCl}_{(\mathrm{aq})}$ was added to achieve a $\mathrm{pH}$ of 3 , and the mixture was extracted with $\mathrm{Et}_{2} \mathrm{O}(3 \mathrm{X} 5 \mathrm{~mL})$, dried over $\mathrm{Na}_{2} \mathrm{SO}_{4}$, filtered, and concentrated under reduced pressure to afford $785 \mathrm{mg}$ of the carboxylic acid as a crude yellow oil. Using the procedure of $\mathrm{Su},{ }^{19} 678 \mathrm{mg}$ (3.54 mmol) was added to $\mathrm{CH}_{2} \mathrm{Cl}_{2}(20 \mathrm{~mL})$. The crude carboxylic acid (785 mg) was added as a solution in $3 \mathrm{~mL}$ of $\mathrm{CH}_{2} \mathrm{Cl}_{2}$ and the resultant mixture was 
allowed to stir at $\mathrm{rt}$ for $30 \mathrm{~min}$. $\mathrm{Bu}_{2} \mathrm{NH}(640 \mu \mathrm{L}, 3.81 \mathrm{mmol})$ was added and the mixture was stirred at $\mathrm{rt}$ overnight. Water $(15 \mathrm{~mL})$ and $\mathrm{NaCl}(4.0 \mathrm{~g})$ were added and the mixture was extracted with $\mathrm{Et}_{2} \mathrm{O}(3 \times 20$ $\mathrm{mL})$. The residue was purified by column chromatography $\left(\mathrm{SiO}_{2}\right.$, gradient ranging from $3 \% \mathrm{EtOAc}$ in hexanes to 5\% EtOAc in hexanes) to provide $664 \mathrm{mg}$ of $\mathbf{S i - 4}$ as a colorless oil (47\% from methyl 3-(3tert-butyldimethylsiloxypropyl) cyclopentene-3-carboxylate). HRMS (ESI) $m / z:[\mathrm{M}+\mathrm{H}]^{+}$calcd for $\mathrm{C}_{23} \mathrm{H}_{46} \mathrm{NO}_{2} \mathrm{Si}, 396.3292$; found 396.3293. IR (ATR) $\mathrm{cm}^{-1} 2954,2929,2856,1627,1472$. ${ }^{1} \mathrm{H}$ NMR (400 $\left.\mathrm{MHz} ; \mathrm{CDCl}_{3} \delta, \mathrm{ppm}\right)$ 6.01-5.97 (m, 1H), 5.76-5.72 (m, 1H), $3.59(\mathrm{t}, J=6.0 \mathrm{~Hz}, 2 \mathrm{H}), 3.42-3.18(\mathrm{~m}, 4 \mathrm{H})$, 2.45-2.37 (m, 2H), 2.32-2.22 (m, 2H), 1.98-1.90 (m, 1H), 1.82-1.72 (m, 1H), 1.67-1.42 (m, 7H) 1.38$1.25(\mathrm{~m}, 4 \mathrm{H}), 1.01-0.87(\mathrm{~m}, 5 \mathrm{H}), 0.89(\mathrm{~s}, 9 \mathrm{H}), 0.04(\mathrm{~s}, 6 \mathrm{H}) .{ }^{13} \mathrm{C} \mathrm{NMR}\left(100 \mathrm{MHz} ; \mathrm{CDCl}_{3} \delta, \mathrm{ppm}\right) 175.5$ 135.7, 129.4, 63.4, 60.0, 47.3 (rotamer), 46.1 (rotamer), 35.5, 34.4, 32.1, 30.9 (rotamer), 29.5 (rotamer), 28.4, 25.9, 20.4 (rotamer), 20.2 (rotamer), 18.3, 13.9, -5.3.

SI-4 (612 mg, $1.55 \mathrm{mmol})$ and THF $(1 \mathrm{~mL})$ were cooled to $0{ }^{\circ} \mathrm{C}$, and $1.9 \mathrm{~mL}$ of a $1.0 \mathrm{M}$ solution of $n$ $\mathrm{Bu}_{4} \mathrm{NF}(1.9 \mathrm{mmol})$ was added. This mixture allowed to warm to rt while stirring overnight. Water (10 $\mathrm{mL})$ and $\mathrm{NaCl}(3.0 \mathrm{~g})$ were added and the mixture was extracted with $\mathrm{Et}_{2} \mathrm{O}(3 \mathrm{X} 15 \mathrm{~mL})$. The combined extracts were dried with $\mathrm{Na}_{2} \mathrm{SO}_{4}$, filtered, and concentrated under reduced pressure to afford $405 \mathrm{mg}$ of the crude desilylated alcohol as a yellow viscous oil. Pyridine $(1.5 \mathrm{~mL})$ was added to the alcohol and the mixture was cooled to $0{ }^{\circ} \mathrm{C}$ with stirring. Tosyl chloride (329 mg, $1.73 \mathrm{mmol}$ ) was added and the mixture was stirred for $2 \mathrm{~h}$ and allowed to warm to rt. $n$ - $\mathrm{Bu} 4 \mathrm{NCl}(400 \mathrm{mg}, 1.44 \mathrm{mmol})$ was added and the mixture was stirred overnight. $\mathrm{H}_{2} \mathrm{O}(10 \mathrm{~mL})$ was added and the mixture was extracted with hexanes $(3 \mathrm{X} 15 \mathrm{~mL})$ and concentrated under reduced pressure. The residue was purified by column chromatography $\left(\mathrm{SiO}_{2}\right.$, gradient ranging from 3\% EtOAc in hexanes to 4\% EtOAc in hexanes) to provide $338 \mathrm{mg}$ of the title compound $\mathbf{8 h}$ as a colorless oil (73\% from SI-4). HRMS (ESI) $m / z:[\mathrm{M}+\mathrm{H}]^{+}$calcd for $\mathrm{C}_{17} \mathrm{H}_{31} \mathrm{ClNO}$ 300.2089; found 300.2086. IR (ATR) $\mathrm{cm}^{-1} 2955,2928,2857,1627,1466 .{ }^{1} \mathrm{H} \mathrm{NMR}\left(400 \mathrm{MHz} ; \mathrm{CDCl}_{3} \delta\right.$, ppm) 6.01-5.97 (m, 1H), 5.80-5.76 (m, 1H), $3.54(\mathrm{t}, J=6.2 \mathrm{~Hz}, 2 \mathrm{H}), 3.43-3.17(\mathrm{~m}, 4 \mathrm{H}), 2.48-2.41(\mathrm{~m}$, 2H), 2.32-2.23 (m, 1H), 1.99-1.87 (m, 1H), 1.81-1.69 (m, 1H), 1.67-1.44 (m, 7H), 1.37-1.27 (m, 4H), 
1.01-0.86 (m, 15H), $0.04(\mathrm{~s}, 6 \mathrm{H}) .{ }^{13} \mathrm{C} \mathrm{NMR}\left(100 \mathrm{MHz} ; \mathrm{CDCl}_{3} \delta, \mathrm{ppm}\right) 174.9,135.3,130.1,59.8,47.3$

(rotamer), 46.3 (rotamer), 45.6, 36.7, 34.6, 32.0, 31.0 (rotamer), 29.4 (rotamer), 28.3, 20.4 (rotamer), 20.2

(rotamer), 14.0.

\section{1-Chloro-2-(4-methoxyphenyl)-5-dodecyne (8i)}

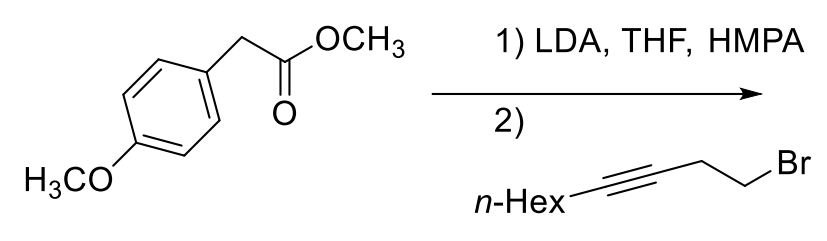

3) $\mathrm{LiAlH}_{4}$, THF

4) $\mathrm{CCl}_{4}, \mathrm{PPh}_{3}, \mathrm{CH}_{2} \mathrm{Cl}_{2}$

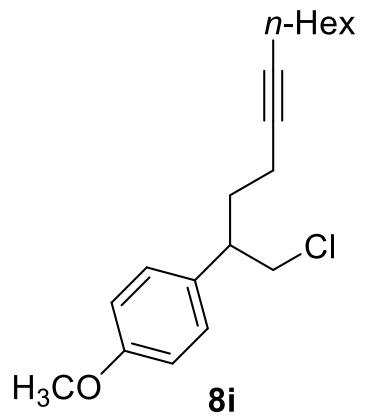

$8 \mathbf{i}$

THF $(18.0 \mathrm{~mL})$ was added to $i-\mathrm{Pr}_{2} \mathrm{NH}(934 \mu \mathrm{L}, 6.65 \mathrm{mmol})$ and the mixture was cooled to $-84{ }^{\circ} \mathrm{C}$. A solution of $2.5 \mathrm{M} n$-BuLi in hexanes $(2.4 \mathrm{~mL}, 6.1 \mathrm{mmol})$ was added and the mixture was stirred for $5 \mathrm{~min}$ at $-84{ }^{\circ} \mathrm{C}$. HMPA $(3.9 \mathrm{~mL}, 0.022 \mathrm{~mol})$ was added and the mixture was stirred for $30 \mathrm{~min}$ at $-84{ }^{\circ} \mathrm{C}$. A solution of methyl 4'-methoxyphenylacetate (1.00 g, $0.00555 \mathrm{~mol})$ in THF (3.0 mL) was added over 10 min. The resultant mixture was stirred for $30 \mathrm{~min}$ at $-84^{\circ} \mathrm{C}$. A solution of 1-bromo-3-decyne (1.12 g, $0.0065 \mathrm{~mol})$ in THF $(1.0 \mathrm{~mL})$ was added, and the mixture was allowed to warm to rt overnight. Half saturated $\mathrm{NH}_{4} \mathrm{Cl}_{(\mathrm{aq})}(20 \mathrm{~mL})$ was added and the mixture was extracted with hexanes $(3 \mathrm{X} 20 \mathrm{~mL})$. The combined organic extracts were washed with water $(2 \mathrm{X} 10 \mathrm{~mL})$, dried over $\mathrm{Na}_{2} \mathrm{SO}_{4}$, filtered, and the solvent was removed under reduced pressure to provide $1.49 \mathrm{~g}$ of the crude alkylated product as a yellow oil. $\mathrm{LiAlH}_{4}(102 \mathrm{mg}, 2.69 \mathrm{mmol})$ was added to THF $(12 \mathrm{~mL})$ at $0{ }^{\circ} \mathrm{C}$. A solution of the crude alkylated product in THF $(5 \mathrm{~mL})$ was added over $5 \mathrm{~min}$. This mixture was allowed to stir for $2 \mathrm{~h}$ at $0{ }^{\circ} \mathrm{C}$. Water $(102 \mu \mathrm{L}), 15 \% \mathrm{NaOH}_{(\mathrm{aq})}(102 \mu \mathrm{L})$, and water $(306 \mu \mathrm{L})$ were added sequentially. The mixture was filtered, the solid being rinsed with $\mathrm{Et}_{2} \mathrm{O}$, and dried over $\mathrm{Na}_{2} \mathrm{SO}_{4}$. The filtrate was concentrated under reduced pressure to afford $1.20 \mathrm{~g}$ of the crude alcohol as a viscous oil. The alcohol was diluted with $\mathrm{CH}_{2} \mathrm{Cl}_{2}(7.6 \mathrm{~mL})$ and triphenylphosphine $(1.19 \mathrm{~g}, 0.00454 \mathrm{~mol})$ was added. $\mathrm{CCl}_{4}(438 \mu \mathrm{L}, 4.54 \mathrm{mmol})$ 
was added and the mixture was stirred overnight. The mixture was concentrated under reduced pressure and the crude material was purified by column chromatography $\left(\mathrm{SiO}_{2}\right.$, gradient ranging from $0.5 \%$ EtOAc in hexanes to $1 \%$ EtOAc in hexanes) to provide $918 \mathrm{mg}$ of the title compound $\mathbf{8 i}$ as a colorless oil (49\% from methyl 4'-methoxyphenylacetate). HRMS (ESI) $m / z$ : $[\mathrm{M}+\mathrm{H}]^{+}$calcd for $\mathrm{C}_{19} \mathrm{H}_{28} \mathrm{ClO}, 307.1823$; found, 307.1822. IR (ATR) $\mathrm{cm}^{-1} 2929,2857,1611,1584,1512,1457 .{ }^{1} \mathrm{H} \mathrm{NMR}\left(400 \mathrm{MHz} ; \mathrm{CDCl}_{3} \delta\right.$, ppm) 7.16-7.12 (m, 2H), 6.91-6.87 (m, 2H), $3.82(\mathrm{~s}, 3 \mathrm{H}), 3.69(\mathrm{~d}, J=6.9 \mathrm{~Hz}, 2 \mathrm{H}), 3.12-3.04(\mathrm{~m}, 1 \mathrm{H})$, 2.19-2.05 (m, 4H), 2.10-1.91 (m, 1H), 1.80-1.71 (m, 1H), 1.55-1.45 (m, 2H), 1.43-1.24 (m, 6H), $0.92(\mathrm{t}, J$ $=6.9 \mathrm{~Hz}, 3 \mathrm{H}) .{ }^{13} \mathrm{C} \mathrm{NMR}\left(100 \mathrm{MHz} ; \mathrm{CDCl}_{3} \delta, \mathrm{ppm}\right) 158.6,133.0,128.7,113.9,81.1,79.0,55.2,49.5$, $46.1,32.5,31.4,29.0,28.6,22.6,18.7,16.6,14.1$.

trans-1-Methoxy-3-(3-methylcyclopentyl)benzene (9a).

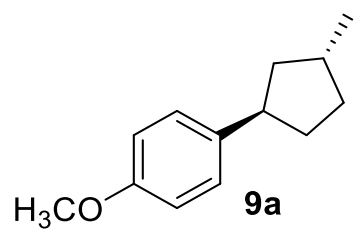

Compound 9a was synthesized from 8a according to the general procedure using 3.5 eq $\mathrm{SmI}_{2}$ and 14.0 eq TEU - at $0{ }^{\circ} \mathrm{C}$ (entry 2 , Table 3 ). The residue was purified by column chromatography $\left(\mathrm{SiO}_{2}\right.$, gradient ranging from $100 \%$ hexanes to $0.5 \%$ EtOAc in hexanes) to provide $46 \mathrm{mg}$ of the title compound as a $6: 1$ mixture of the trans $(\mathbf{9 a})$ and cis isomers $(86 \%)$ as a colorless oil. The relative stereochemistry of the major diastereomer 9a, was determined via nOe difference experiments. HRMS (EI) $m / z: \mathbf{M}^{+}$calcd for $\mathrm{C}_{13} \mathrm{H}_{18} \mathrm{O}$ 190.1358; found 190.1365. IR (ATR) $\mathrm{cm}^{-1} 2997,2948,2865,2834,1612,1583,1511 .{ }^{1} \mathrm{H}$ NMR (400 MHz; $\mathrm{CDCl}_{3} \delta$, ppm; major trans isomer) 7.20-7.15 (m, 2H), 6.88-6.84 (m, 2H), $3.81(\mathrm{~s}, 3 \mathrm{H})$, 3.18-3.08 (m, 1H), 2.29-1.95 (m, 3H), 1.87-1.78 (m, 1H), 1.73-1.55 (m, 2H), 1.31-1.18 (m, 1H), $1.06(\mathrm{~d}, J$ $=6.9 \mathrm{~Hz}, 3 \mathrm{H}) .{ }^{13} \mathrm{C} \mathrm{NMR}\left(100 \mathrm{MHz} ; \mathrm{CDCl}_{3} \delta\right.$, ppm; major trans isomer $)$ 157.5, 139.2, 127.9, 113.6, 55.2, $43.6,42.6,35.5,35.2,33.5,21.7$. 


\section{5-(4-Methoxyphenyl)-1-hexene (10a).}

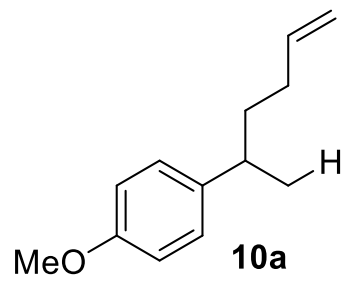

Compound 10a was synthesized from 8a according to the general procedure using 3.5 eq $\mathrm{SmI}_{2}$ and 14.0 eq TEU- at $0{ }^{\circ} \mathrm{C}$ (entry 2 , Table 3 ). The residue was purified by column chromatography $\left(\mathrm{SiO}_{2}\right.$, gradient ranging from $100 \%$ hexanes to $0.5 \%$ EtOAc in hexanes) to provide $5 \mathrm{mg}$ of the title compound 10a (9\%) as a colorless oil. ${ }^{20}{ }^{1} \mathrm{H} \mathrm{NMR}\left(400 \mathrm{MHz} ; \mathrm{CDCl}_{3} \delta, \mathrm{ppm}\right) 7.12,(\mathrm{~d}, J=8.2 \mathrm{~Hz}, 2 \mathrm{H}), 6.86(\mathrm{~d}, J=8.2 \mathrm{~Hz}$, 2H), 5.86-5.74 (m, 1H), 5.02-4.92 (m, 2H), $3.81(\mathrm{~s}, 3 \mathrm{H}), 2.73-2.63(\mathrm{~m}, 1 \mathrm{H}), 2.03-1.91(\mathrm{~m}, 2 \mathrm{H}), 1.70-1.60$ $(\mathrm{m}, 2 \mathrm{H}), 1.24(\mathrm{~d}, J=6.9 \mathrm{~Hz}, 3 \mathrm{H}) .{ }^{13} \mathrm{C} \mathrm{NMR}\left(100 \mathrm{MHz} ; \mathrm{CDCl}_{3} \delta, \mathrm{ppm}\right) 157.8,139.5,138.9,127.8,114.4$, $113.6,55.1,38.3,37.6,31.8,22.5$.

\section{2,3-Dihydro-1-methyl-1H-benz[e]indene (9b).}

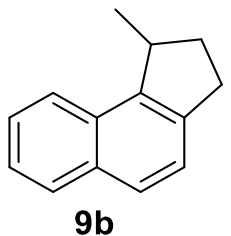

Compound $\mathbf{9 b}$ was synthesized from $\mathbf{8 b}$ according to the general procedure using $3.5 \mathrm{eq} \mathrm{SmI}_{2}$ and 14.0 eq TEU- at $-98{ }^{\circ} \mathrm{C}$ (entry 3 , Table 3 ). The residue was purified by column chromatography $\left(\mathrm{SiO}_{2}\right.$, hexanes) to provide $32 \mathrm{mg}$ of the title compound $9 \mathbf{b}(62 \%)$ as a colorless oil. ${ }^{1} \mathrm{H}$ and ${ }^{13} \mathrm{C}$ NMR were in accord with literature spectra. ${ }^{21}$ 


\section{2-(3-Butenyl)naphthalene (10b).}

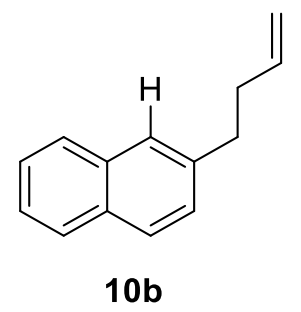

Compound 10b was synthesized from $\mathbf{8 b}$ according to the general procedure using 3.5 eq $\mathrm{SmI}_{2}$ and 14.0 eq TEU ${ }^{-}$at $-98{ }^{\circ} \mathrm{C}$ (entry 3 , Table 3 ). The residue was purified by column chromatography $\left(\mathrm{SiO}_{2}\right.$, hexanes) to provide $2 \mathrm{mg}$ of the title compound $\mathbf{1 0 b}(4 \%)$ as a colorless oil. ${ }^{1} \mathrm{H}$ and ${ }^{13} \mathrm{C}$ NMR were in accord with literature spectra. ${ }^{21}$

5,6-Dihydro-5-methylbenzo[f]quinolone (9c).

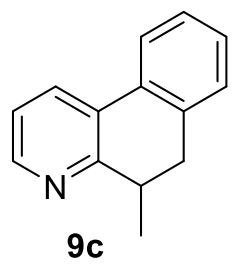

On a $1.04 \mathrm{mmol}$ scale- To an ice-cold mixture of $1.05 \mathrm{~g}$ TEU $(7.29 \mathrm{mmol})$ and $29.2 \mathrm{~mL}$ of THF was added $2.91 \mathrm{~mL}$ of a $2.5 \mathrm{M}$ solution of $n$-BuLi (7.28 mmol) in hexanes. A solution of $222 \mathrm{mg}(1.04 \mathrm{mmol})$ of pyridyl fluoride $\mathbf{8 c}$ in $2.0 \mathrm{~mL}$ of THF was added (entry 4, Table 3). This mixture was stirred for $5 \mathrm{~min}$ then $31.2 \mathrm{~mL}$ of a $0.094 \mathrm{M}$ solution of $\mathrm{SmI}_{2}(3.64 \mathrm{mmol})$ in $\mathrm{THF}$ was added. The mixture was allowed to warm to rt and stirred overnight. Water $(16 \mathrm{~mL})$ was added and the mixture extracted with a 2:1 mixture of hexanes and $\mathrm{Et}_{2} \mathrm{O}(5 \times 10 \mathrm{~mL})$. The concentrated mixture was purified by column chromatography $\left(\mathrm{SiO}_{2}\right.$, gradient ranging from 3\% EtOAc in hexanes to 6\% EtOAc in hexanes) to provide $132 \mathrm{mg}$ of the title compound $9 \mathbf{c}(65 \%)$ as a colorless oil. HRMS (ESI) $m / z$ : $[\mathrm{M}+\mathrm{H}]^{+}$calcd for $\mathrm{C}_{14} \mathrm{H}_{14} \mathrm{~N} 196.1121$; found 196.1121. IR (ATR) $\mathrm{cm}^{-1} 3058,2960,2927,2868,1588,1561,1492,1466 .{ }^{1} \mathrm{H}$ NMR (400 MHz; $\left.\mathrm{CDCl}_{3} \delta, \mathrm{ppm}\right) 8.49(\mathrm{~d}, J=4.6 \mathrm{~Hz}, 1 \mathrm{H}), 8.03(\mathrm{~d}, J=7.8 \mathrm{~Hz}, 1 \mathrm{H}), 7.73(\mathrm{~d}, J=7.3 \mathrm{~Hz}, 1 \mathrm{H}), 7.37-7.22(\mathrm{~m}$, 
4H), 3.29-3.15 (m, 2H), $2.81(\mathrm{dd}, J=15.1,6.4 \mathrm{~Hz}, 1 \mathrm{H}), 1.31(\mathrm{~d}, J=6.9 \mathrm{~Hz}, 3 \mathrm{H}) .{ }^{13} \mathrm{C} \mathrm{NMR}(100 \mathrm{MHz}$; $\left.\mathrm{CDCl}_{3} \delta, \mathrm{ppm}\right) 161.2,148.0,135.6,132.4,130.8,128.9,128.7,128.3,127.0,123.5,122.1,36.2,35.4$, 18.2 .

\section{3-(2-Allylphenyl)-pyridine (10c).}

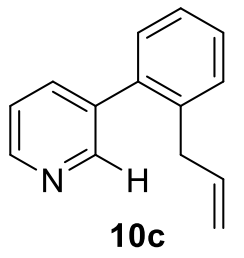

On a $1.04 \mathrm{mmol}$ scale- To an ice-cold mixture of $1.05 \mathrm{~g}$ TEU $(7.29 \mathrm{mmol})$ and $29.2 \mathrm{~mL}$ of THF was added $2.91 \mathrm{~mL}$ of a $2.5 \mathrm{M}$ solution of $n$-BuLi $(7.28 \mathrm{mmol})$ in hexanes. A solution of $222 \mathrm{mg}(1.04 \mathrm{mmol})$ of pyridyl fluoride $8 \mathbf{c}$ in $2.0 \mathrm{~mL}$ of THF was added (entry 4, Table 3). This mixture was stirred for $5 \mathrm{~min}$ then $31.2 \mathrm{~mL}$ of a $0.094 \mathrm{M}$ solution of $\mathrm{SmI}_{2}(3.64 \mathrm{mmol})$ in $\mathrm{THF}$ was added. The mixture was allowed to warm to $\mathrm{rt}$ and stirred overnight. Water $(16 \mathrm{~mL})$ was added and the mixture extracted with a 2:1 mixture of hexanes and $\mathrm{Et}_{2} \mathrm{O}(5 \times 10 \mathrm{~mL})$. The concentrated mixture was purified by column chromatography $\left(\mathrm{SiO}_{2}\right.$, gradient ranging from 3\% EtOAc in hexanes to 6\% EtOAc in hexanes) to provide $8 \mathrm{mg}$ of the title compound 10c (4\%) as a colorless oil. ${ }^{1} \mathrm{H}$ and ${ }^{13} \mathrm{C}$ NMR were in accord with literature spectra. ${ }^{22}$

\section{5,6-Dihydro-6-methylbenzo[f]quinolone (9d).}

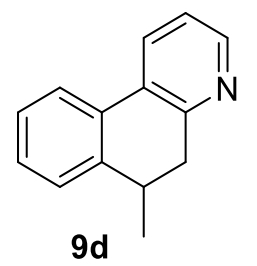

Compound 9d was synthesized from $\mathbf{8 d}$ with a modification to the general procedure involving the coaddition of 3.5 eq of $\mathrm{SmI}_{2}$ and $\mathbf{8 d}$ to 14.0 eq TEU- at $-98{ }^{\circ} \mathrm{C}$ (entry 6, Table 3). The residue was purified by column chromatography ( $\mathrm{SiO}_{2}$, gradient ranging from 3\% EtOAc in hexanes to 8\% EtOAc in hexanes) to provide $32 \mathrm{mg}$ of the title compound $9 d(57 \%)$ as a colorless oil. HRMS (ESI) $\mathrm{m} / \mathrm{z}:[\mathrm{M}+\mathrm{H}]^{+}$calcd for $\mathrm{C}_{14} \mathrm{H}_{14} \mathrm{~N}$ 196.1121; found 196.1115. IR (ATR) $\mathrm{cm}^{-1} 3059,2958,1588,1562,1490,1466 .{ }^{1} \mathrm{H}$ NMR (400 
$\left.\mathrm{MHz} ; \mathrm{CDCl}_{3} \delta, \mathrm{ppm}\right) 8.46(\mathrm{dd}, J=4.6,1.4 \mathrm{~Hz}, 1 \mathrm{H}), 8.03(\mathrm{dd}, J=7.8,1.4 \mathrm{~Hz}, 1 \mathrm{H}), 7.77-7.72(\mathrm{~m}, 1 \mathrm{H})$, 7.37-7.32 (m, 3H), 7.27-7.24 (m, 1H), 3.29-3.14 (m, 2H), $2.95(\mathrm{dd}, J=15.1,6.0 \mathrm{~Hz}, 1 \mathrm{H}), 1.26(\mathrm{~d}, J=6.9$ $\mathrm{Hz}, 3 \mathrm{H}) .{ }^{13} \mathrm{C} \mathrm{NMR}\left(100 \mathrm{MHz} ; \mathrm{CDCl}_{3} \delta, \mathrm{ppm}\right)$ 156.6, 148.0, 141.8, 131.9, 130.4, 129.2, 128.6, 127.0, 124.0, 122.2, 39.1, 33.0, 20.1.

trans-2-(1-Propenyl)-3-phenylpyridine (10d).

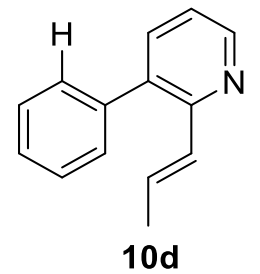

Compound 10d was synthesized from $8 \mathbf{e}$ with a modification to the general procedure involving the coaddition of 3.5 eq of $\mathrm{SmI}_{2}$ and $\mathbf{8 e}$ to 14.0 eq $\mathrm{TEU}^{-}$at $-98^{\circ} \mathrm{C}$ (entry 6, Table 3). The residue was purified by column chromatography $\left(\mathrm{SiO}_{2}\right.$, gradient ranging from 3\% EtOAc in hexanes to $8 \%$ EtOAc in hexanes) to provide $3 \mathrm{mg}$ of the title compound 10d (5\%) as a colorless oil. HRMS (ESI) $m / z:[\mathrm{M}+\mathrm{H}]^{+}$calcd for $\mathrm{C}_{14} \mathrm{H}_{14} \mathrm{~N}$ 196.1121; found 196.1116. IR (ATR) $\mathrm{cm}^{-1} 3040,2960,2927,2852,1650,1600,1579,1555$, 1496, 1440. ${ }^{1} \mathrm{H}$ NMR (400 MHz; $\left.\mathrm{CDCl}_{3} \delta, \mathrm{ppm}\right)$ 8.58-8.55 (m, $\left.1 \mathrm{H}\right), 7.55(\mathrm{dd}, J=7.8,1.8 \mathrm{~Hz}, 1 \mathrm{H}), 7.50-$ $7.38(\mathrm{~m}, 3 \mathrm{H}), 7.38-7.33(\mathrm{~m}, 2 \mathrm{H}), 7.19(\mathrm{dd}, J=7.8,4.6 \mathrm{~Hz}, 1 \mathrm{H}), 7.02-6.91(\mathrm{~m}, 1 \mathrm{H}), 6.54-6.47(\mathrm{~m}, 1 \mathrm{H})$, $1.87(\mathrm{dd}, J=6.9,1.8 \mathrm{~Hz}, 3 \mathrm{H}) .{ }^{13} \mathrm{C} \mathrm{NMR}\left(100 \mathrm{MHz} ; \mathrm{CDCl}_{3} \delta, \mathrm{ppm}\right) 152.7,148.3,139.2,137.8,135.1$, $131.8,129.6,128.4,128.3,127.4,121.3,18.5$.

cis-3-[Ethoxymethoxymethyl]octahydro-3a(1H)-pentalene (9e).

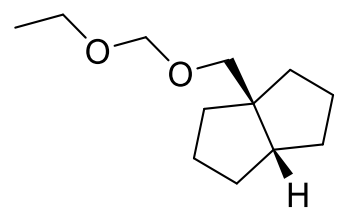

$9 e$ 
Compound 9e was synthesized from $8 \mathbf{e}$ according to the general procedure using $3.5 \mathrm{eq} \mathrm{SmI}_{2}$ and $14.0 \mathrm{eq}$ TEU- at $0{ }^{\circ} \mathrm{C}$ (entry 7 , Table 3 ). The residue was purified by column chromatography $\left(\mathrm{SiO}_{2}\right.$, gradient ranging from hexanes to $2 \%$ EtOAc in hexanes) to provide $43 \mathrm{mg}$ of the title compound $9 \mathrm{e}$ (76\%) as a colorless oil. HRMS (APCI) $m / z$ : $\left[\mathrm{M}-\mathrm{OC}_{2} \mathrm{H}_{5}\right]^{+}$calcd for $\mathrm{C}_{10} \mathrm{H}_{17} \mathrm{O} 153.1273$; found 153.1277. IR (ATR) $\mathrm{cm}^{-1} 2934,2861,1450,1380 .{ }^{1} \mathrm{H}$ NMR (400 MHz; $\left.\mathrm{CDCl}_{3} \delta, \mathrm{ppm}\right) 4.70$ (s, 2H), 3.62 (q, $\left.J=7.3 \mathrm{~Hz}, 2 \mathrm{H}\right)$, $3.35(\mathrm{~s}, 2 \mathrm{H}), 2.05-1.96(\mathrm{~m}, 1 \mathrm{H}), 1.79-1.68(\mathrm{~m}, 2 \mathrm{H}), 1.68-1.54(\mathrm{~m}, 4 \mathrm{H}), 1.54-1.43(\mathrm{~m}, 2 \mathrm{H}), 1.42-1.33(\mathrm{~m}$, 2H), 1.31-1.21 (m, 5H). ${ }^{13} \mathrm{C} \mathrm{NMR} \mathrm{(100} \mathrm{MHz;} \mathrm{CDCl}_{3} \delta$, ppm) 95.4, 75.6, 63.0, 54.2, 46.7, 37.6, 33.9, 25.7, 15.2.

\section{3-Butyl[(2-ethoxymethoxy)methyl] cyclopentene (10f).}

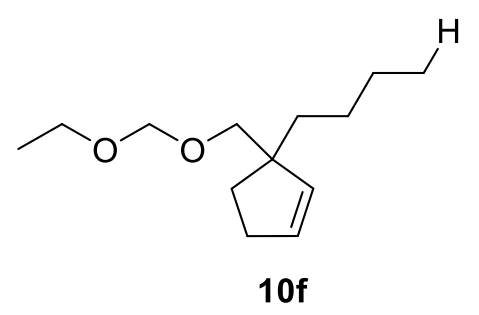

Compound 10f was synthesized from $\mathbf{8 f}$ according to the general procedure using $3.5 \mathrm{eq} \mathrm{SmI}_{2}$ and $14.0 \mathrm{eq}$ TEU - at $0{ }^{\circ} \mathrm{C}$ (entry 8 , Table 3 ). The residue was purified by column chromatography $\left(\mathrm{SiO}_{2}\right.$, gradient ranging from hexanes to $2 \%$ EtOAc in hexanes) to provide $41 \mathrm{mg}$ of the title compound $\mathbf{1 0 f}(68 \%)$ as a colorless oil. HRMS (APCI) $m / z$ : $\left[\mathrm{M}-\mathrm{OC}_{2} \mathrm{H}_{5}\right]^{+}$calcd for $\mathrm{C}_{11} \mathrm{H}_{19} \mathrm{O}$ 167.1430, found; 167.1426. IR (ATR) $\mathrm{cm}^{-1} 3049,2928,2858,1458,1379 .{ }^{1} \mathrm{H}$ NMR (400 MHz; $\mathrm{CDCl}_{3} \delta$, ppm) 5.78-5.72 (m, 1H), 5.57$5.51(\mathrm{~m}, 1 \mathrm{H}), 4.69(\mathrm{~s}, 2 \mathrm{H}), 3.61(\mathrm{q}, J=6.9 \mathrm{~Hz}, 2 \mathrm{H}), 3.40(\mathrm{~s}, 2 \mathrm{H}), 2.39-2.32(\mathrm{~m}, 2 \mathrm{H}), 1.80-1.71(\mathrm{~m}, 1 \mathrm{H})$, $1.70-1.61(\mathrm{~m}, 1 \mathrm{H}), 1.47-1.40(\mathrm{~m}, 2 \mathrm{H}), 1.35-1.18(\mathrm{~m}, 7 \mathrm{H}), 0.91(\mathrm{t}, J=6.9 \mathrm{~Hz}, 3 \mathrm{H}) .{ }^{13} \mathrm{C} \mathrm{NMR}(100 \mathrm{MHz}$; $\left.\mathrm{CDCl}_{3} \delta, \mathrm{ppm}\right) 136.1,130.9,95.3,74.2,63.0,53.1,36.6,32.0,31.7,26.7,23.5,15.1,14.2$. 
cis-Phenyl methyl octahydro-3a(1H)-pentalene carbamate $(9 \mathrm{~g})$.

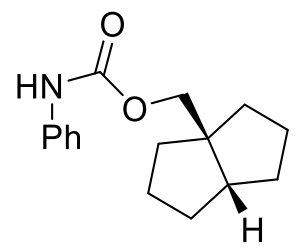

$9 \mathrm{~g}$

Compound $9 \mathrm{~g}$ was synthesized from $\mathbf{8 g}$ according to the general procedure using $3.5 \mathrm{eq} \mathrm{SmI}_{2}$ and $14.0 \mathrm{eq}$ TEU ${ }^{-}$at $0{ }^{\circ} \mathrm{C}$ (entry 9 , Table 3 ). The residue was purified by column chromatography $\left(\mathrm{SiO}_{2}\right.$, gradient ranging from $1 \%$ to $2 \%$ EtOAc in hexanes) to provide $52 \mathrm{mg}$ of the title compound $\mathbf{9 g}(70 \%)$ as a colorless oil. HRMS (ESI) $m / z$ : [M $+\mathrm{Na}]^{+}$calcd for $\mathrm{C}_{16} \mathrm{H}_{21} \mathrm{NaNO}_{2} 282.1465$; found 282.1466. IR (ATR) $\mathrm{cm}^{-1} 3314,2937,2861,1703,1599,1526,1501 .{ }^{1} \mathrm{H}$ NMR (400 MHz; $\left.\mathrm{CDCl}_{3} \delta, \mathrm{ppm}\right)$ 7.45-7.37 (m, 2H), 7.36-7.29 (m, 2H), 7.11-7.05 (m, 1H), 6.62-6.54 (b, 1H), $4.02(\mathrm{~s}, 2 \mathrm{H}), 2.14-2.06(\mathrm{~m}, 1 \mathrm{H}), 1.83-1.72(\mathrm{~m}$, $2 \mathrm{H}), 1.70-1.48(\mathrm{~m}, 6 \mathrm{H}), 1.47-1.38(\mathrm{~m}, 2 \mathrm{H}), 1.36-1.25(\mathrm{~m}, 2 \mathrm{H}) .{ }^{13} \mathrm{C} \mathrm{NMR}\left(100 \mathrm{MHz} ; \mathrm{CDCl}_{3} \delta, \mathrm{ppm}\right)$ 154.0, 137.9, 129.0, 123.3, 118.6, 72.1, 53.6, 46.5, 37.4, 33.9, 25.6.

cis- $N, N$-Dibutyl octahydro-3a(1H)-pentalene-3-carboxamide (9h).

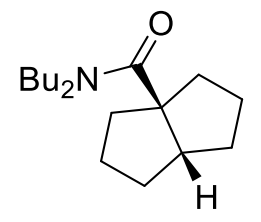

$9 \mathrm{~h}$

Compound $9 \mathbf{h}$ was synthesized from $\mathbf{8 h}$ according to the general procedure using $3.5 \mathrm{eq} \mathrm{SmI}_{2}$ and $14.0 \mathrm{eq}$ TEU - at $0{ }^{\circ} \mathrm{C}$ (entry 10 , Table 3 ). The residue was purified by column chromatography $\left(\mathrm{SiO}_{2}\right.$, gradient ranging from $1 \%$ to $7 \%$ EtOAc in hexanes) to provide $59 \mathrm{mg}$ of the title compound $\mathbf{9 h}(78 \%)$ as a colorless oil. HRMS (ESI) $\mathrm{m} / \mathrm{z}$ : $[\mathrm{M}+\mathrm{H}]^{+}$calcd for $\mathrm{C}_{17} \mathrm{H}_{32} \mathrm{NO} 266.2478$; found 266.2481. IR (ATR) $\mathrm{cm}^{-1}$ 2934, 2862, 1625. ${ }^{1} \mathrm{H}$ NMR (400 MHz; $\mathrm{CDCl}_{3} \delta$, ppm) 3.45-3.36 (m, 1H), 3.34-3.23 (m, 4H), 1.96-1.86 (m, 2H), 1.82-1.61 (m, 6H), 1.61-1.44 (6H), 1.39-1.24 (m, 6H), 1.01-0.88 (m, 6H). ${ }^{13} \mathrm{C}$ NMR (100 MHz; 
$\left.\mathrm{CDCl}_{3} \delta, \mathrm{ppm}\right) 177.4,60.4,48.1,47.5$ (rotamer), 45.6 (rotamer), 40.0, 32.7, 30.8 (rotamer), 29.4 (rotamer), 26.5, 20.3, 13.9.

\section{1-n-Hexylidene-3-(4-methoxyphenyl)cyclopentane (9i).}

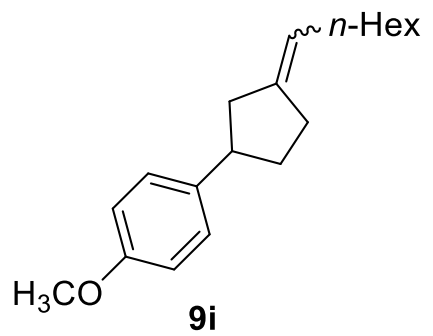

Compound $9 \mathbf{i}$ was synthesized from $\mathbf{8 i}$ according to the general procedure using 3.5 eq $\mathrm{SmI}_{2}$ and 14.0 eq TEU - at $0{ }^{\circ} \mathrm{C}$ (entry 11 , Table 3 ). The residue was purified by column chromatography $\left(\mathrm{SiO}_{2}\right.$, gradient ranging from hexanes to $0.6 \%$ EtOAc in hexanes) to provide $36 \mathrm{mg}$ of the title compound $9 \mathbf{i}(47 \%)$ as an inseparable $\mathrm{E} / \mathrm{Z}$ mixture (1:1), as a colorless oil. HRMS (APCI) $\mathrm{m} / \mathrm{z}:[\mathrm{M}+\mathrm{H}]^{+}$calcd for $\mathrm{C}_{19} \mathrm{H}_{29} \mathrm{O}$ 273.2213; found 273.2214. IR (ATR) $\mathrm{cm}^{-1} 2952,2924,1612,1512,1463 .{ }^{1} \mathrm{H} \mathrm{NMR}\left(400 \mathrm{MHz} ; \mathrm{CDCl}_{3} \delta\right.$, ppm; for both isomers) 7.22-7.15 (m, 2H), 6.89-6.83 (m, 2H), 5.41-5.28 (m, 1H), 3.83-3.79 (b, 3H), 3.13$2.97(\mathrm{~m}, 1 \mathrm{H}), 2.78-2.62(\mathrm{~m}, 1 \mathrm{H}), 2.53-2.28(\mathrm{~m}, 2 \mathrm{H}), 2.28-2.03(\mathrm{~m}, 2 \mathrm{H}), 2.03-1.93(\mathrm{~m}, 2 \mathrm{H}), 1.78-1.59(\mathrm{~m}$, $1 \mathrm{H}), 1.41-1.19(\mathrm{~m}, 8 \mathrm{H}), 0.94-0.85(\mathrm{~m}, 3 \mathrm{H}) .{ }^{13} \mathrm{C} \mathrm{NMR}\left(100 \mathrm{MHz} ; \mathrm{CDCl}_{3} \delta\right.$, ppm; for both isomers) 157.8 , 157.8, 141.7, 137.5 (E/Z), 137.2 (E/Z), 127.9, 121.2 (E/Z), $121.1(\mathrm{E} / \mathrm{Z}), 113.6,55.3,44.7$ (E/Z), 44.4 (E/Z), 41.7, 37.4, 34.3 (E/Z), 34.3 (E/Z), 33.1, 31.8, 29.7, 29.1, 22.7, 14.1.

\section{2-(4-Methoxyphenyl)-5-dodecyne (10i).}

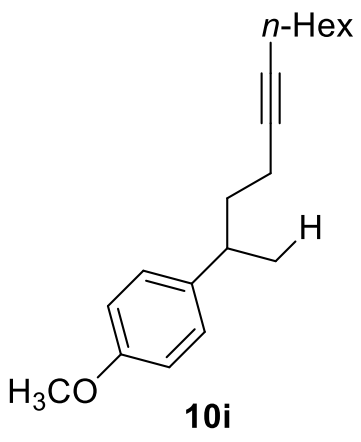


Compound 10i was synthesized from $8 \mathbf{i}$ according to the general procedure using $3.5 \mathrm{eq} \mathrm{SmI}_{2}$ and 14.0 eq TEU - at $0{ }^{\circ} \mathrm{C}$ (entry 11 , Table 3 ). The residue was purified by column chromatography $\left(\mathrm{SiO}_{2}\right.$, gradient ranging from hexanes to $0.6 \%$ EtOAc in hexanes) to provide $30 \mathrm{mg}$ of the title compound $\mathbf{1 0} \mathbf{i}(39 \%)$ as a colorless oil. HRMS (APCI) $\mathrm{m} / z$ : $[\mathrm{M}+\mathrm{H}]^{+}$calcd for $\mathrm{C}_{19} \mathrm{H}_{29} \mathrm{O}$ 273.2213; found 273.2213. IR (ATR) $\mathrm{cm}^{-1}$ 2955, 2918, 1614, 1512, 1466. ${ }^{1} \mathrm{H}$ NMR $\left(400 \mathrm{MHz} ; \mathrm{CDCl}_{3} \delta, \mathrm{ppm}\right) 7.14(\mathrm{~d}, J=8.7 \mathrm{~Hz}, 2 \mathrm{H}), 6.86(\mathrm{~d}, J=$ $8.7 \mathrm{~Hz}, 2 \mathrm{H}), 3.81(\mathrm{~s}, 3 \mathrm{H}), 2.88-2.78(\mathrm{~m} \mathrm{1H}), 2.20-2.12(\mathrm{~m}, 2 \mathrm{H}), 2.12-1.94(\mathrm{~m}, 2 \mathrm{H}), 1.82-1.66(\mathrm{~m}, 2 \mathrm{H})$, $1.55-1.46(\mathrm{~m}, 2 \mathrm{H}), 1.45-1.27(\mathrm{~m}, 6 \mathrm{H}), 1.26(\mathrm{~d}, J=6.9 \mathrm{~Hz}, 3 \mathrm{H}), 0.93(\mathrm{t}, J=6.4 \mathrm{~Hz}, 3 \mathrm{H}) .{ }^{13} \mathrm{C} \mathrm{NMR}(100$

$\left.\mathrm{MHz} ; \mathrm{CDCl}_{3} \delta, \mathrm{ppm}\right) 157.8,138.8,127.9,113.7,80.5,79.8,55.2,37.9,37.8,31.4,29.1,28.6,22.7,22.6$,

18.7, 17.0, 14.1,

\section{Supplement References:}

1. Curran, D. P.; Xin, G.; Zhang, W.; Dowd, P. Tetrahedron 1997, 53, 9023-9042.

2. McDonald, C. E.; Ramsey, J. D.; Sampsell, D. G.; Butler, J. A.; Cecchini, M. R. Org. Lett. 2010, 12, 5178-5181.

3. McDonald, C. E.; Ramsey, J. D.; Sampsell, D. G.; Anderson, L. A.; Krebs, J. E.; Smith, S. N. Tetrahedron 2013, 69, 2947-2953.

4. McDonald, C. E.; Ramsey, J. D.; McAtee, C. C.; Mauck, J. R.; Hale, E. M.; Cumens, J. A. J.Org. Chem. 2016, 81, 5903-5913.

5. Bardagí, J.; Vaillard, S. E.; Rossi, R. A. Tetrahedron Lett. 2006, 47, 3149-3152.

6. Vaillard, S. E.; Postigo, A.; Rossi, R. A. J. Org. Chem. 2004, 69, 2037-2041.

7. Tietze, L.; Düfert, M. A.; Hungerland, T.; Oum, K.; Lenzer, T. Chem. Eur. J. 2011, 17, 8452-846.

8. Asano, K.; Matsubara, S. Org. Lett. 2009, 11, 1757-1759.

9. Ma, Y.; Hider, R. Tetrahedron Lett. 2010, 51, 5230-5233.

10. Riego, E.; Bayó, N.; Cuevas, C.; Albericio, F.; Álverez, M. Tetrahedron 2005, 61, 1407-1411.

11. McMahon, C.; Renn, M.; Alexanian, E. J. Organic Lett. 2016, 18, 4148-4150.

12. Nyström, J.; McCanna, J.; Helquist, P.; Amouroux, R. Synthesis 1988, 56-58.

13. Tamada, S.; Mori, K.; Matsui, M. Agric. Biol. Chem. 1978, 42, 191-192.

14. Su, W.; Gong, T.; Lu, X.; Xu, M.; Yu, C.; Xu, Z.; Yu, H.; Xiao, B.; Fu, Y. Angew. Chem. Int. Ed. 2015, 54, 12957-12961.

15. Wlochal, J.; Bailey, A. Tetrahedron Lett. 2015, 56, 6791-6794.

16. Heaton, B.; McCaffrey, D. Dalton Trans. 1979, 6, 1078-1083.

17. Peterson, T.; Becker, M.; Knochel, P. Angew. Chem. Int. Ed. 2014, 53, 7933-7937.

18. Bartlett, P. A. Johnson, W. S. Tetrahedron Lett. 1970, 11, 4459-4462.

19. Su, X. Biorganic Med. Chem. 2012, 20, 6394-6402.19. Velusamy, T.; Rao, G. Ind. J. Chem., Sect. B: Org. Chem. Incl. Med. Chem. 1981, 20B, 351-4.

20. Velusamy, T.; Rao, G. Ind. J. Chem., Sect. B: Org. Chem. Incl. Med. Chem. 1981, 20B, 351-4.

21. Abeywickrema, A.; Beckwith, A. L. J.; Gerba, S. J. Org. Chem. 1987, 52, 4072-4078.

22. Boyington, A.; Riu, M.; Jui, N. J. Am. Chem. Soc. 2017, 139, 6582-6585. 


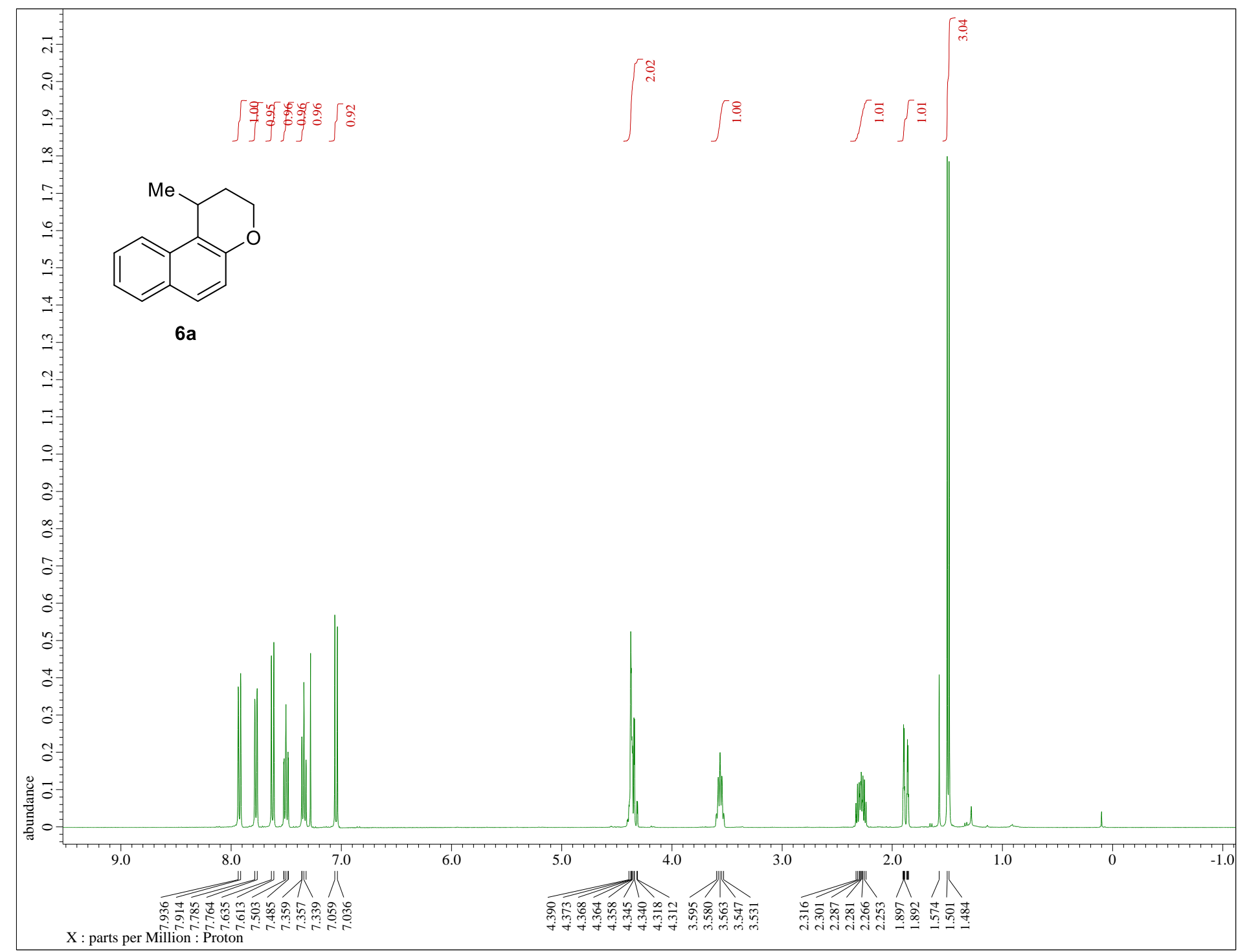

${ }^{1} \mathrm{H} \mathrm{NMR}, 400 \mathrm{MHz}, \mathrm{CDCl}_{3}$ 


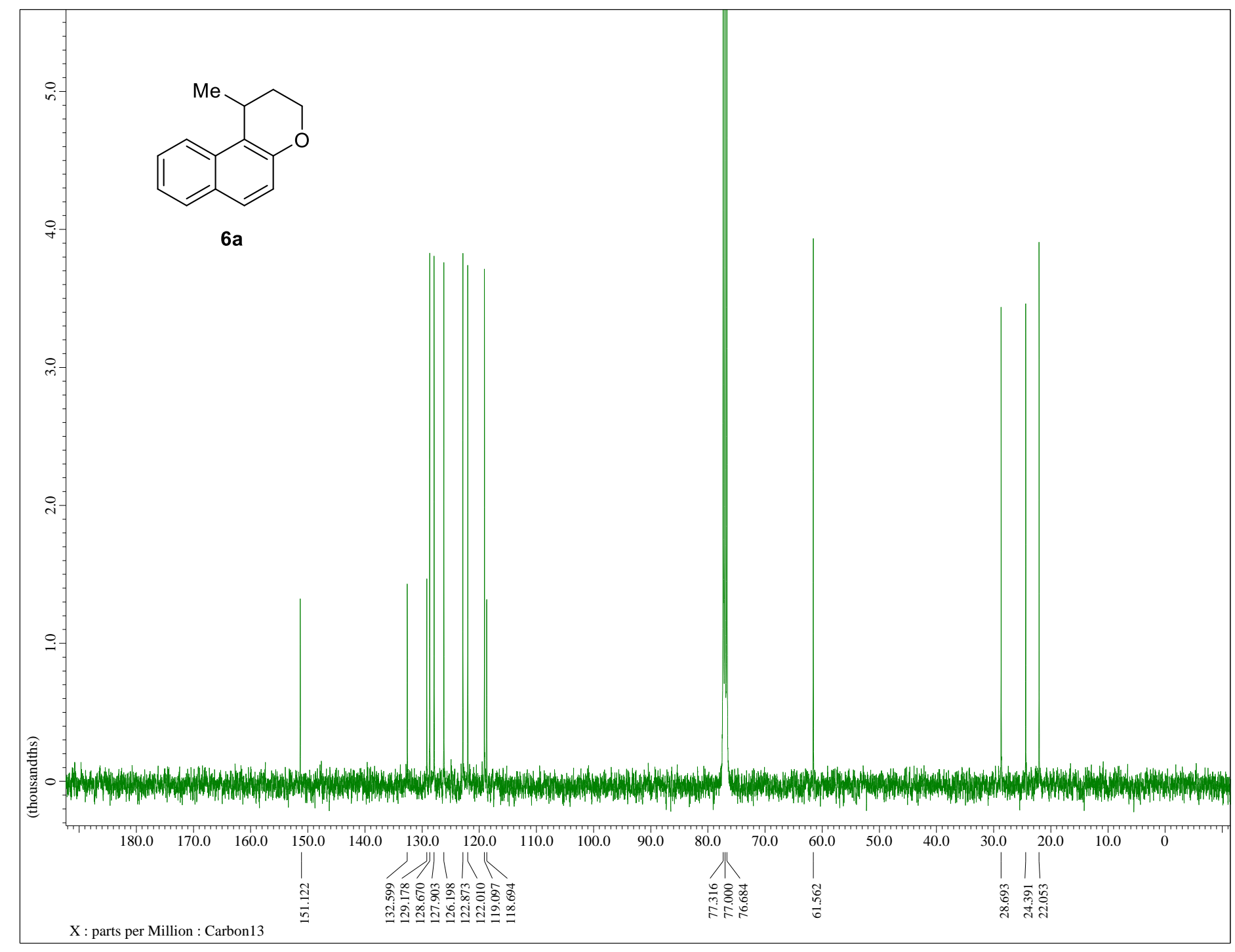

${ }^{13} \mathrm{C} \mathrm{NMR}, 100 \mathrm{MHz}, \mathrm{CDCl}_{3}$ 


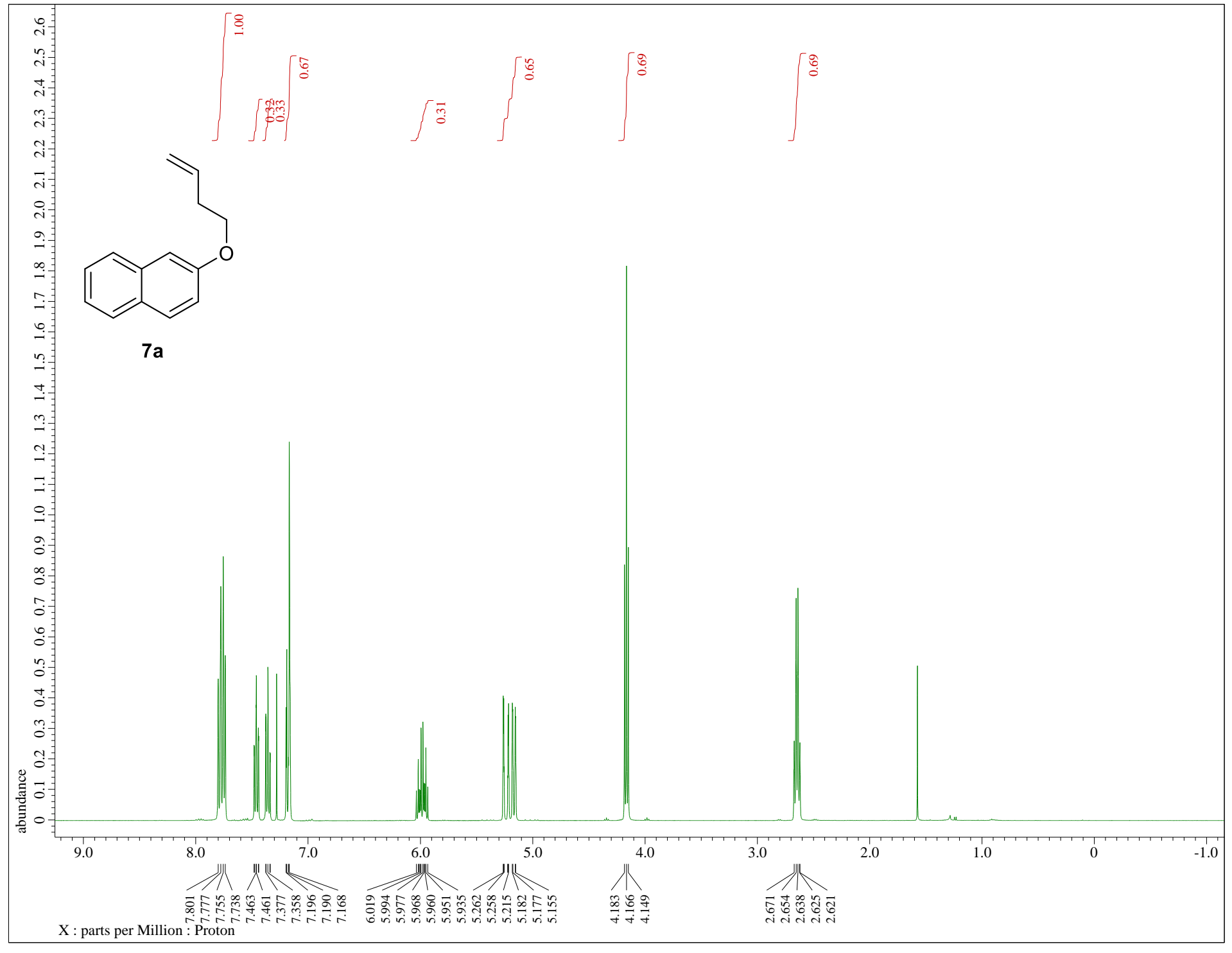

${ }^{1} \mathrm{H} \mathrm{NMR}, 400 \mathrm{MHz}, \mathrm{CDCl}_{3}$ 


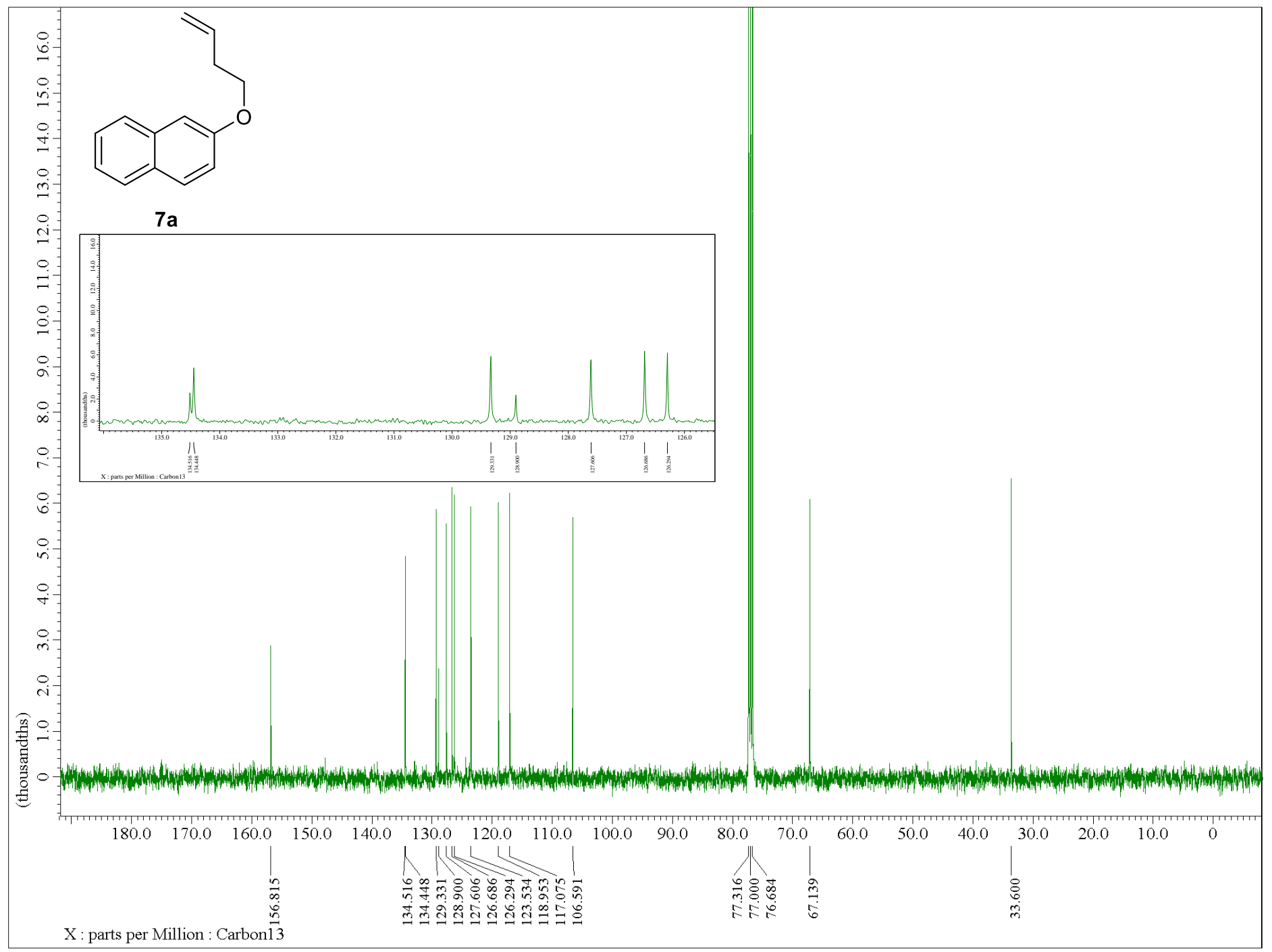

${ }^{13} \mathrm{C}$ NMR, $100 \mathrm{MHz}, \mathrm{CDCl}_{3}$ 


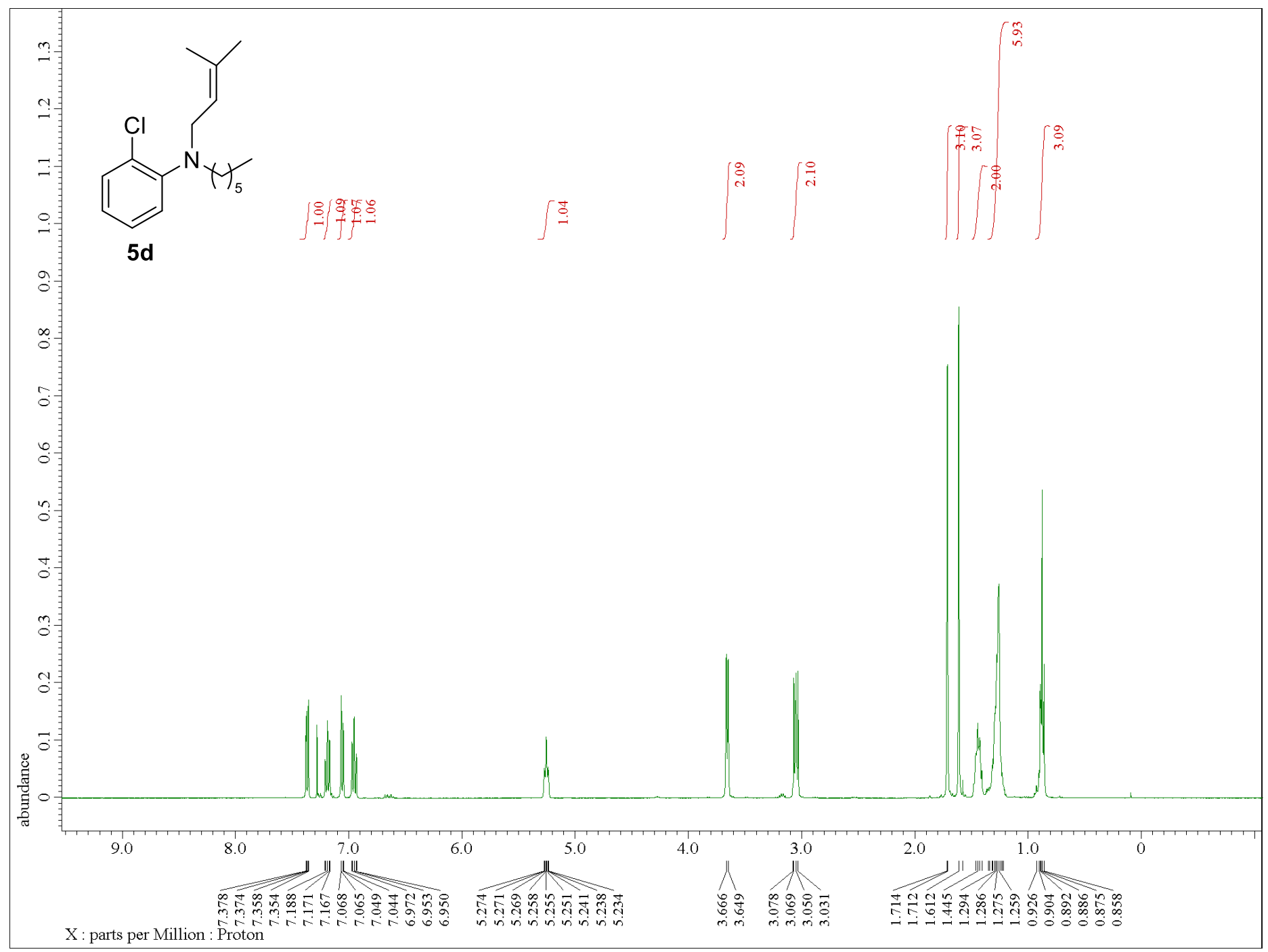

${ }^{1} \mathrm{H} \mathrm{NMR}, 400 \mathrm{MHz}, \mathrm{CDCl}_{3}$ 


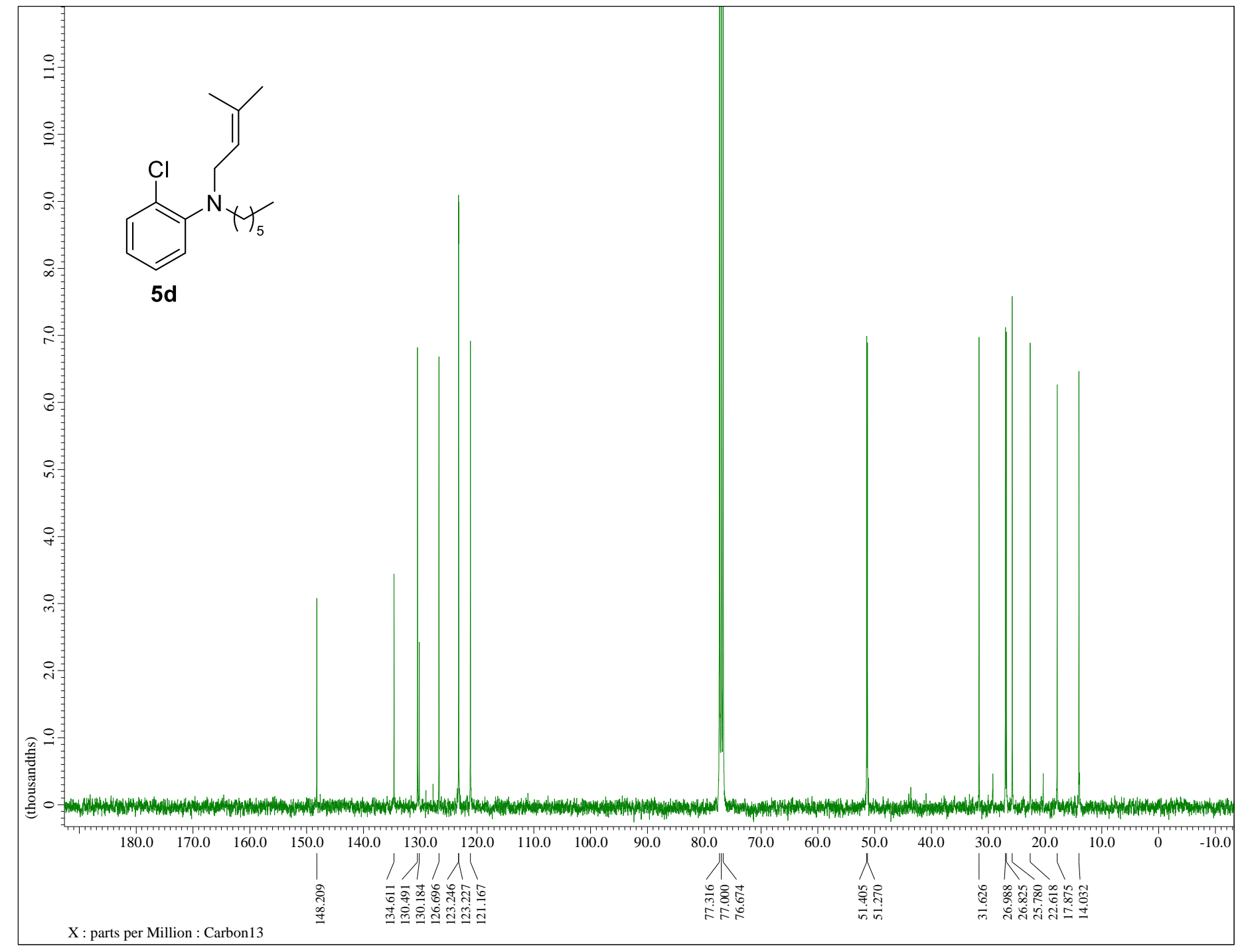

${ }^{13} \mathrm{C} \mathrm{NMR}, 100 \mathrm{MHz}, \mathrm{CDCl}_{3}$ 


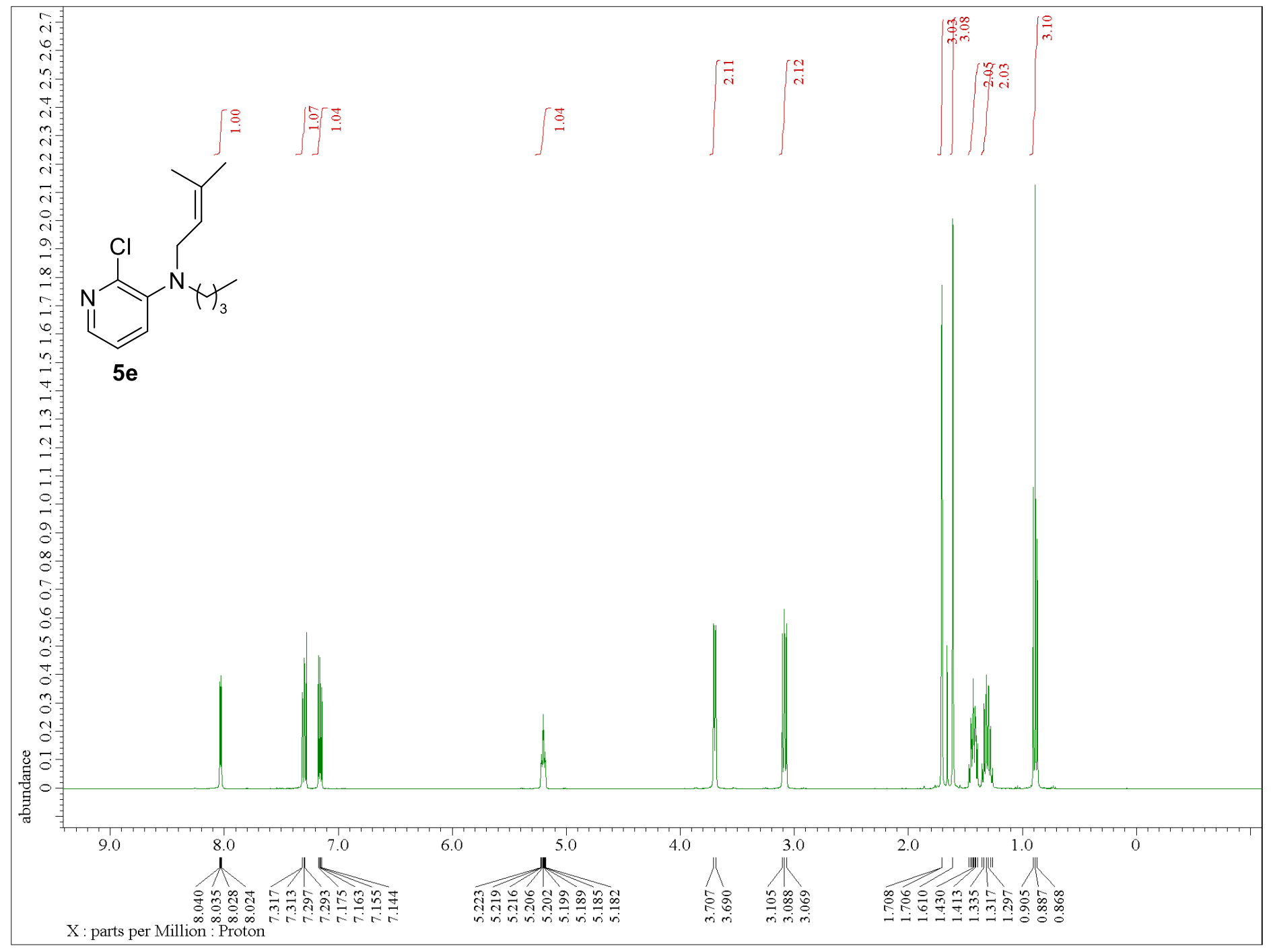

${ }^{1} \mathrm{H} \mathrm{NMR}, 400 \mathrm{MHz}, \mathrm{CDCl}_{3}$ 


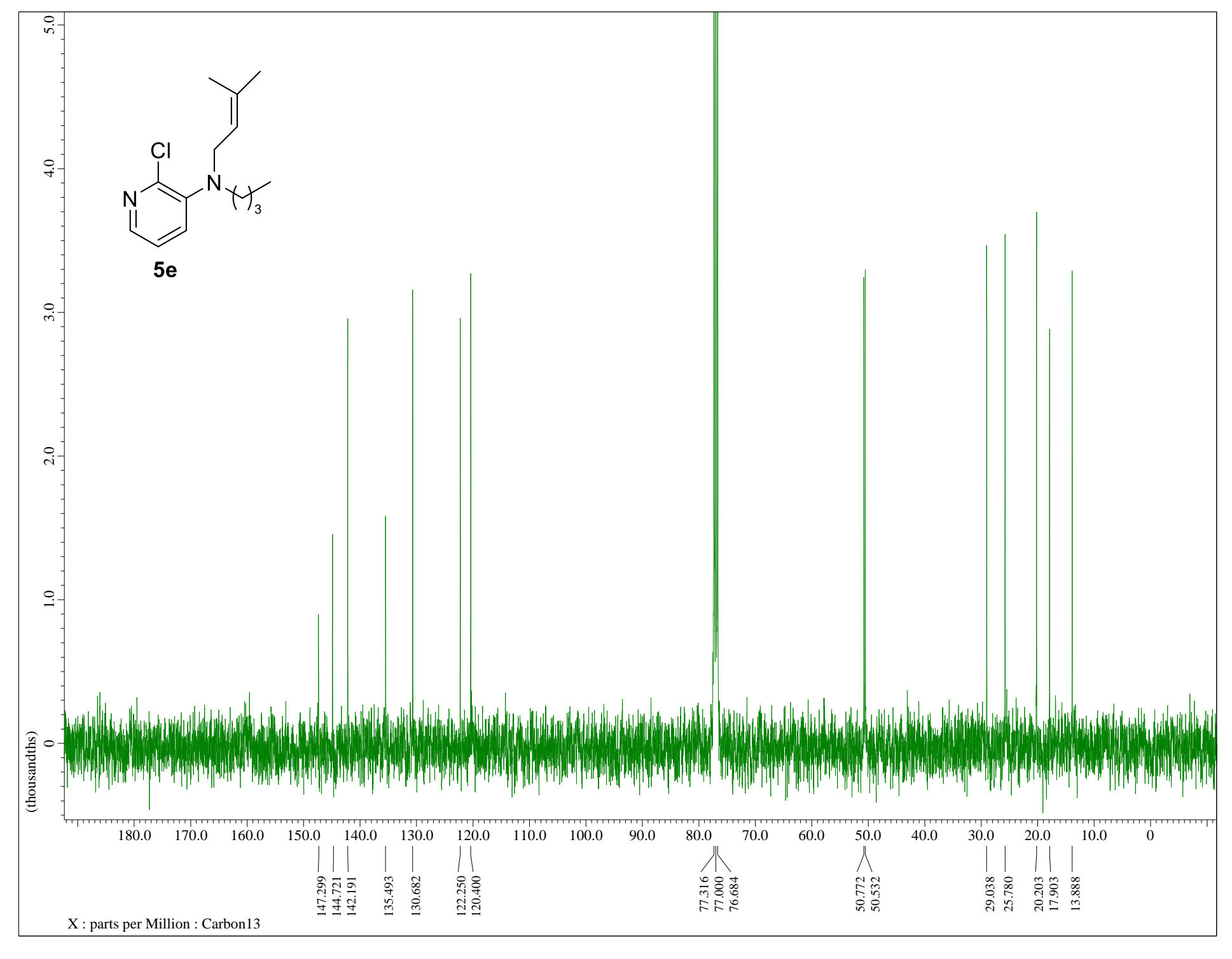

${ }^{13} \mathrm{CNMR}, 100 \mathrm{MHz}, \mathrm{CDCl}_{3}$ 


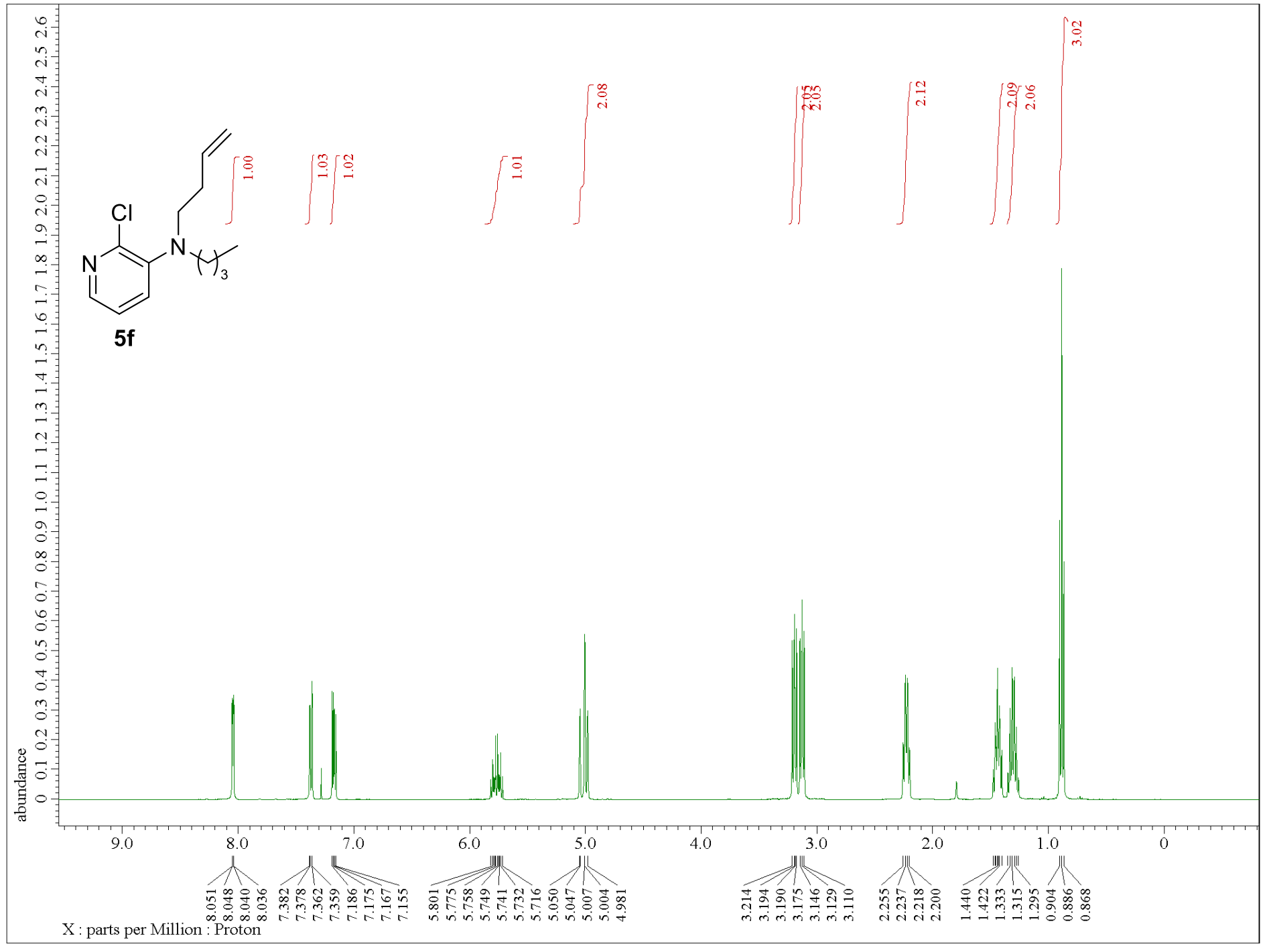

${ }^{1} \mathrm{H} \mathrm{NMR}, 400 \mathrm{MHz}, \mathrm{CDCl}_{3}$ 


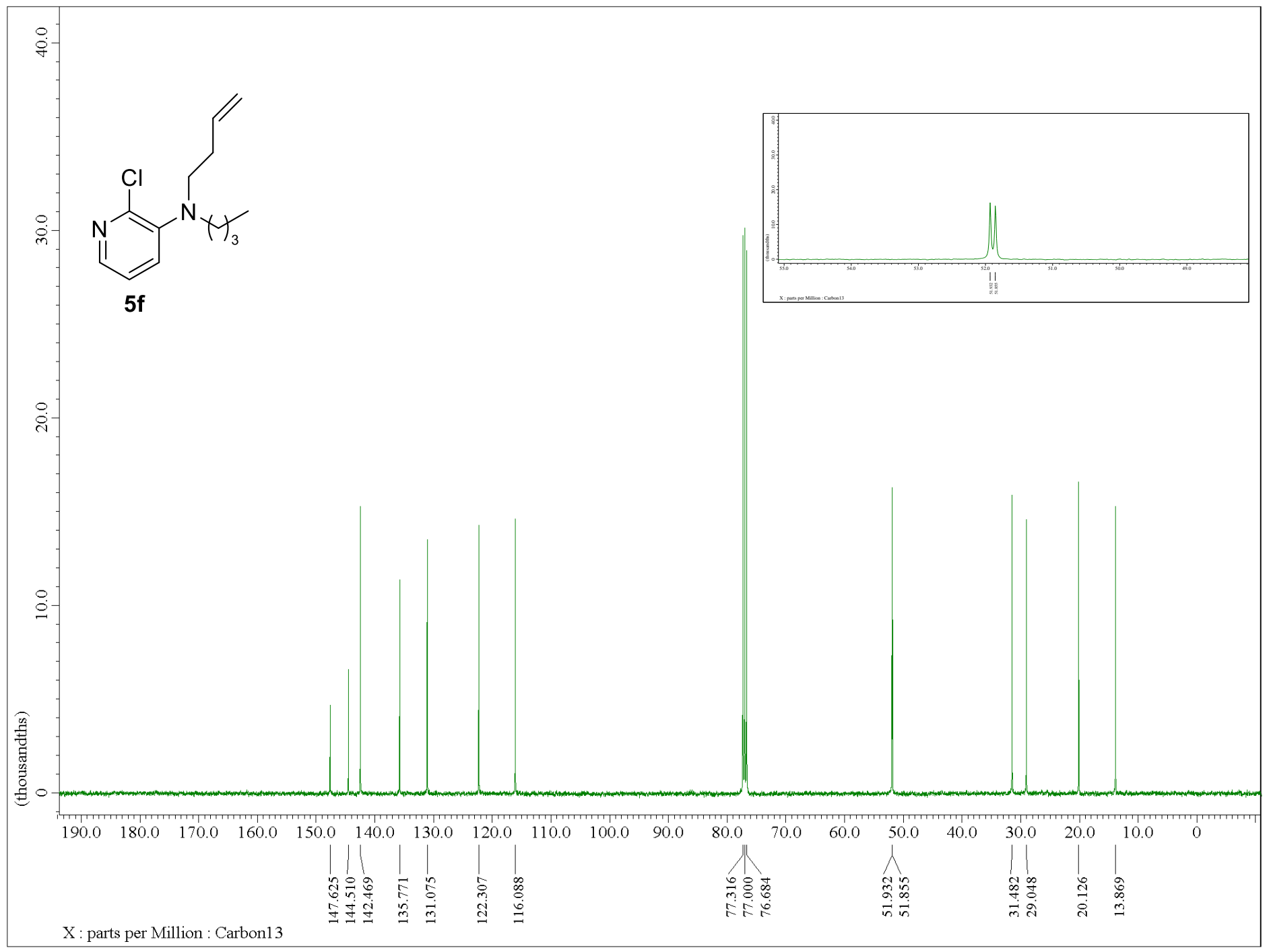

${ }^{13} \mathrm{C} \mathrm{NMR}, 100 \mathrm{MHz}, \mathrm{CDCl}_{3}$ 


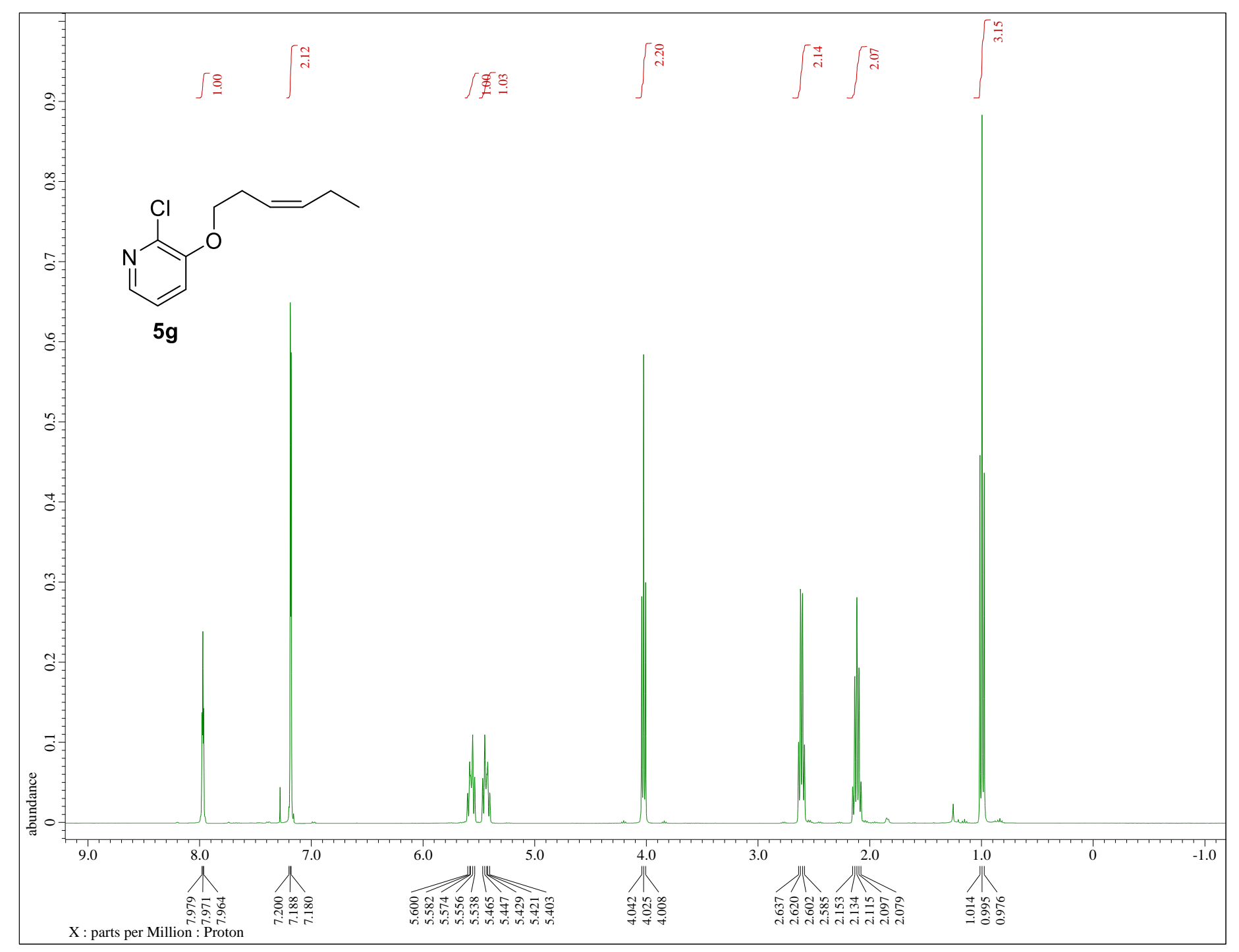

${ }^{1} \mathrm{H} \mathrm{NMR}, 400 \mathrm{MHz}, \mathrm{CDCl}_{3}$ 


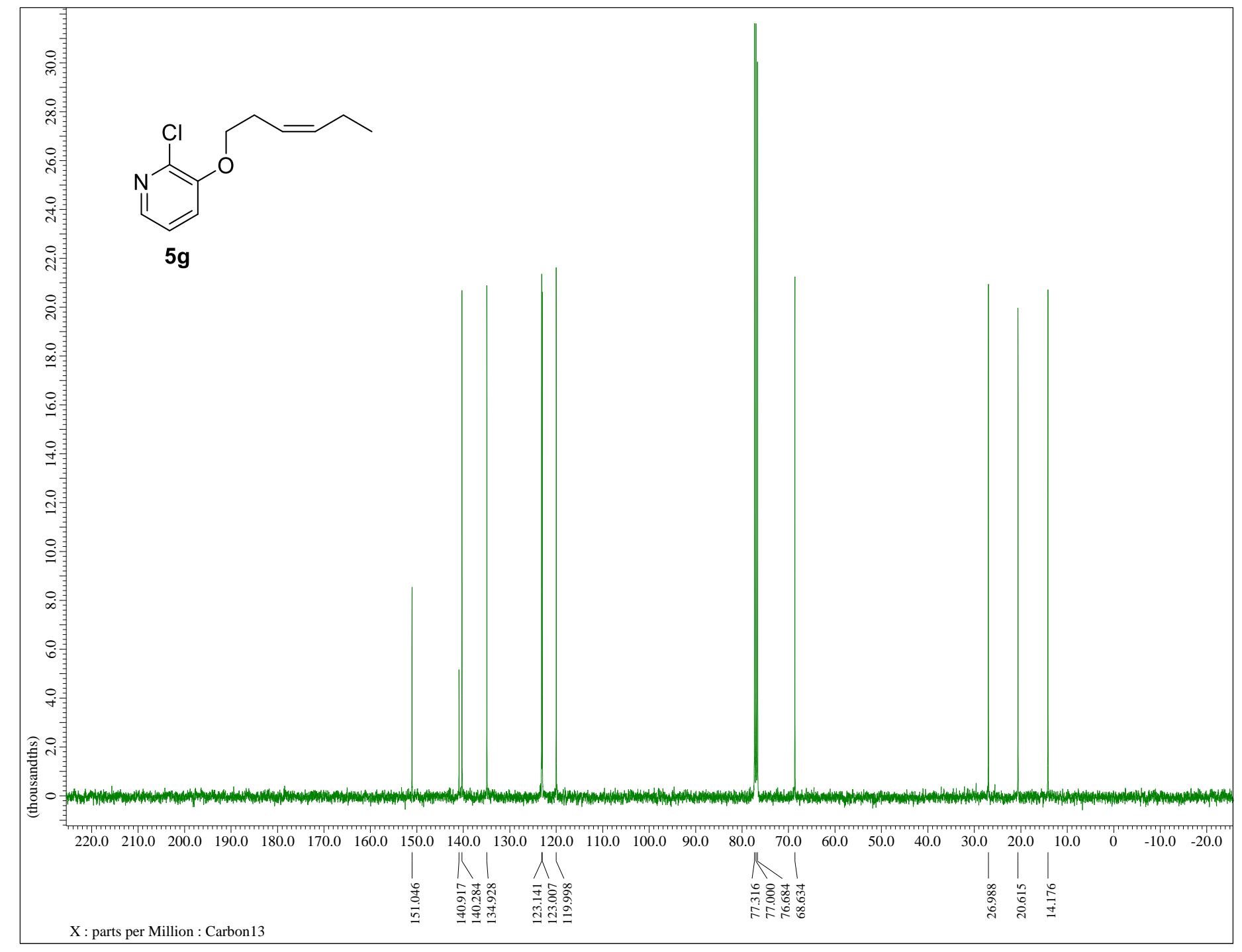

${ }^{13} \mathrm{C} \mathrm{NMR}, 100 \mathrm{MHz}, \mathrm{CDCl}_{3}$ 


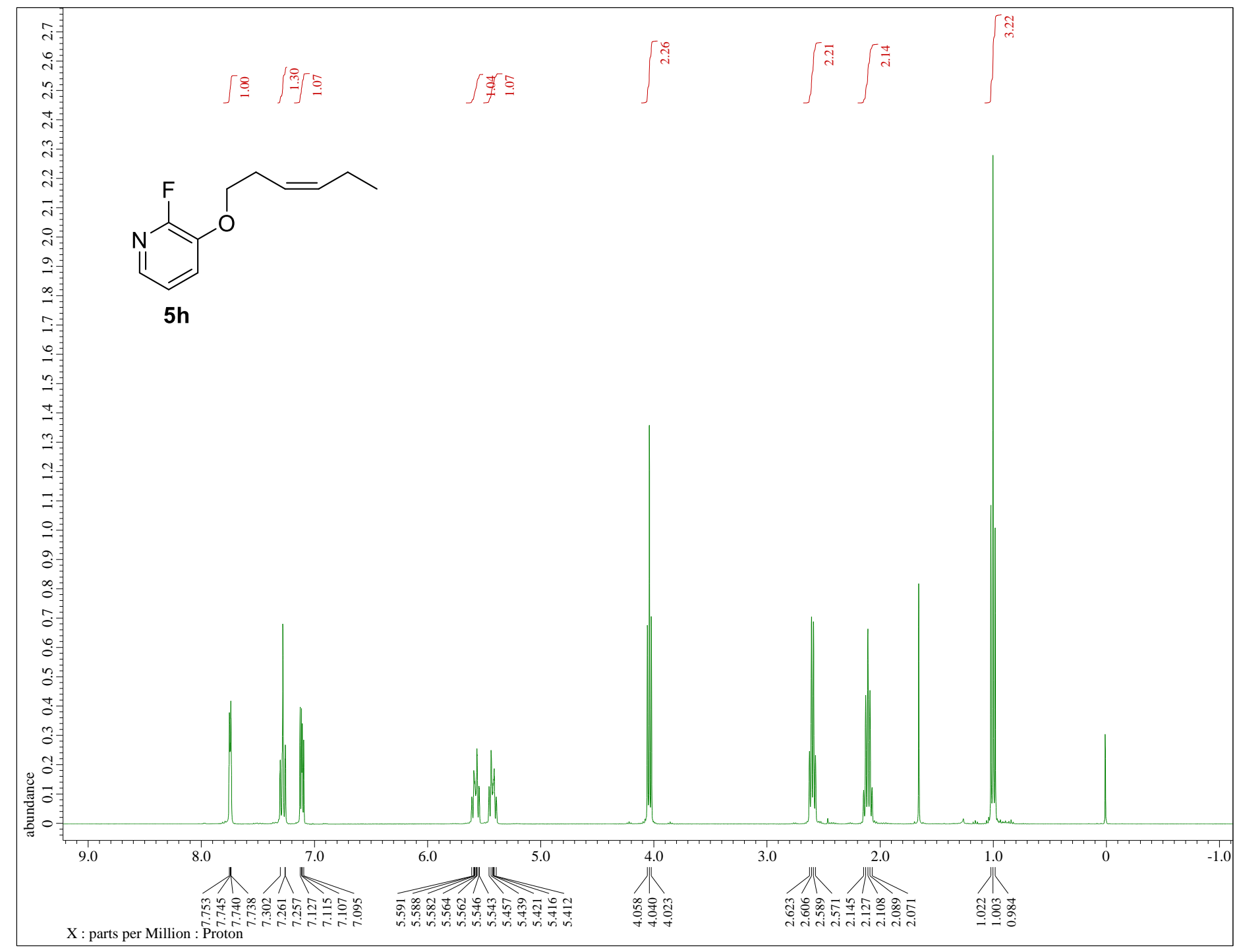

${ }^{1} \mathrm{H} \mathrm{NMR}, 400 \mathrm{MHz}, \mathrm{CDCl}_{3}$ 


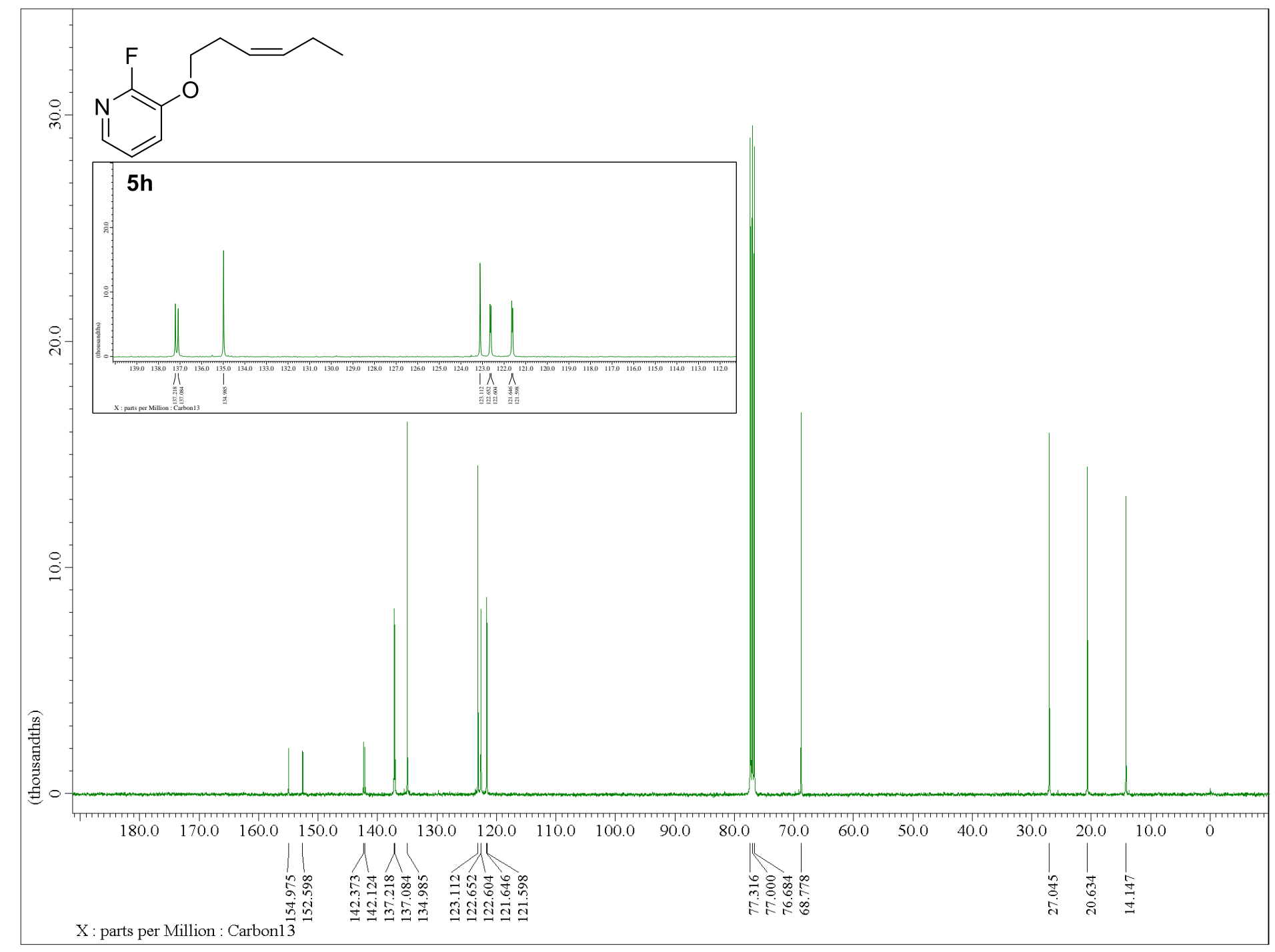

${ }^{13} \mathrm{C} \mathrm{NMR}, 100 \mathrm{MHz}, \mathrm{CDCl}_{3}$ 


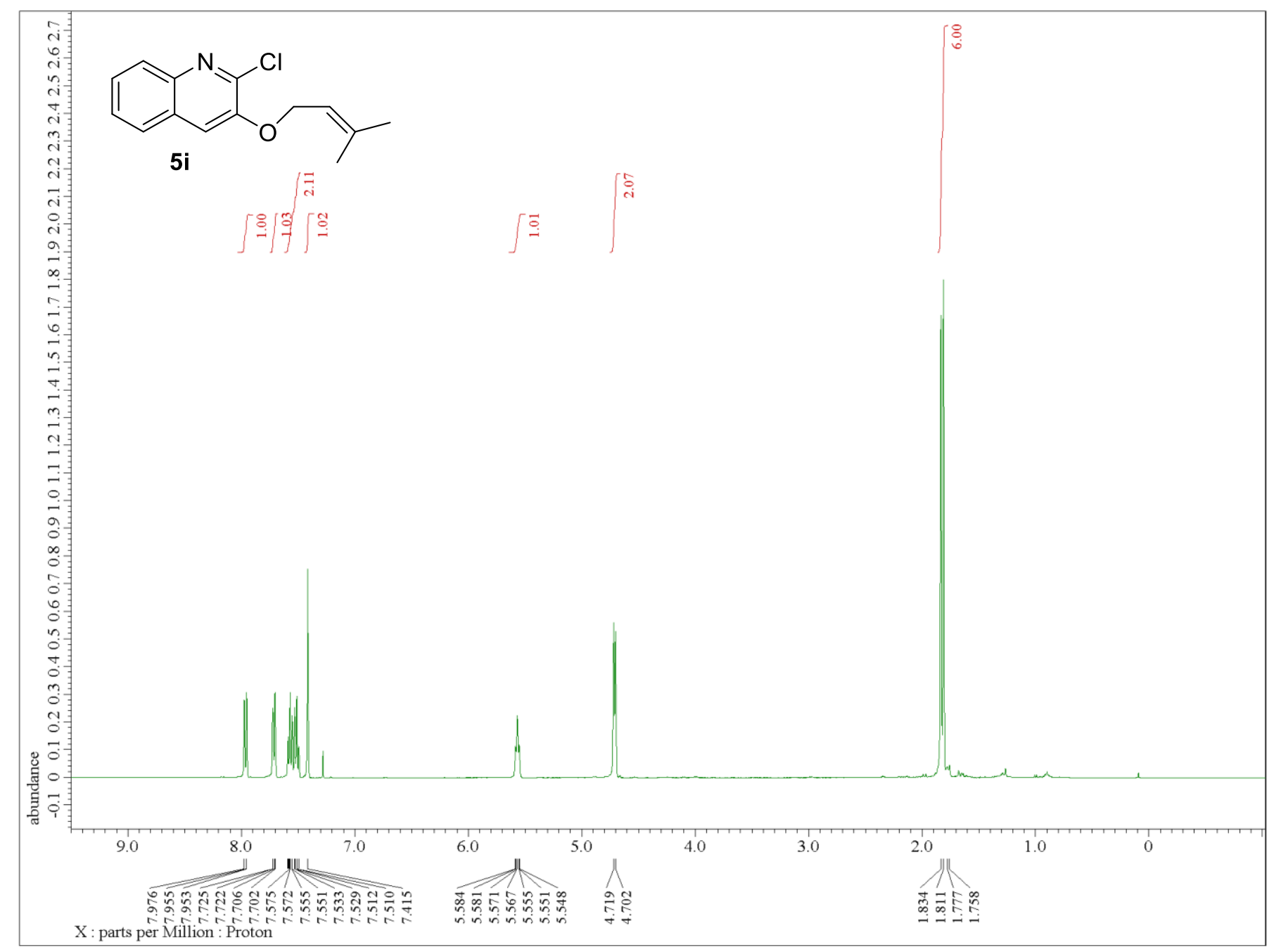

${ }^{1} \mathrm{H} \mathrm{NMR}, 400 \mathrm{MHz}, \mathrm{CDCl}_{3}$ 


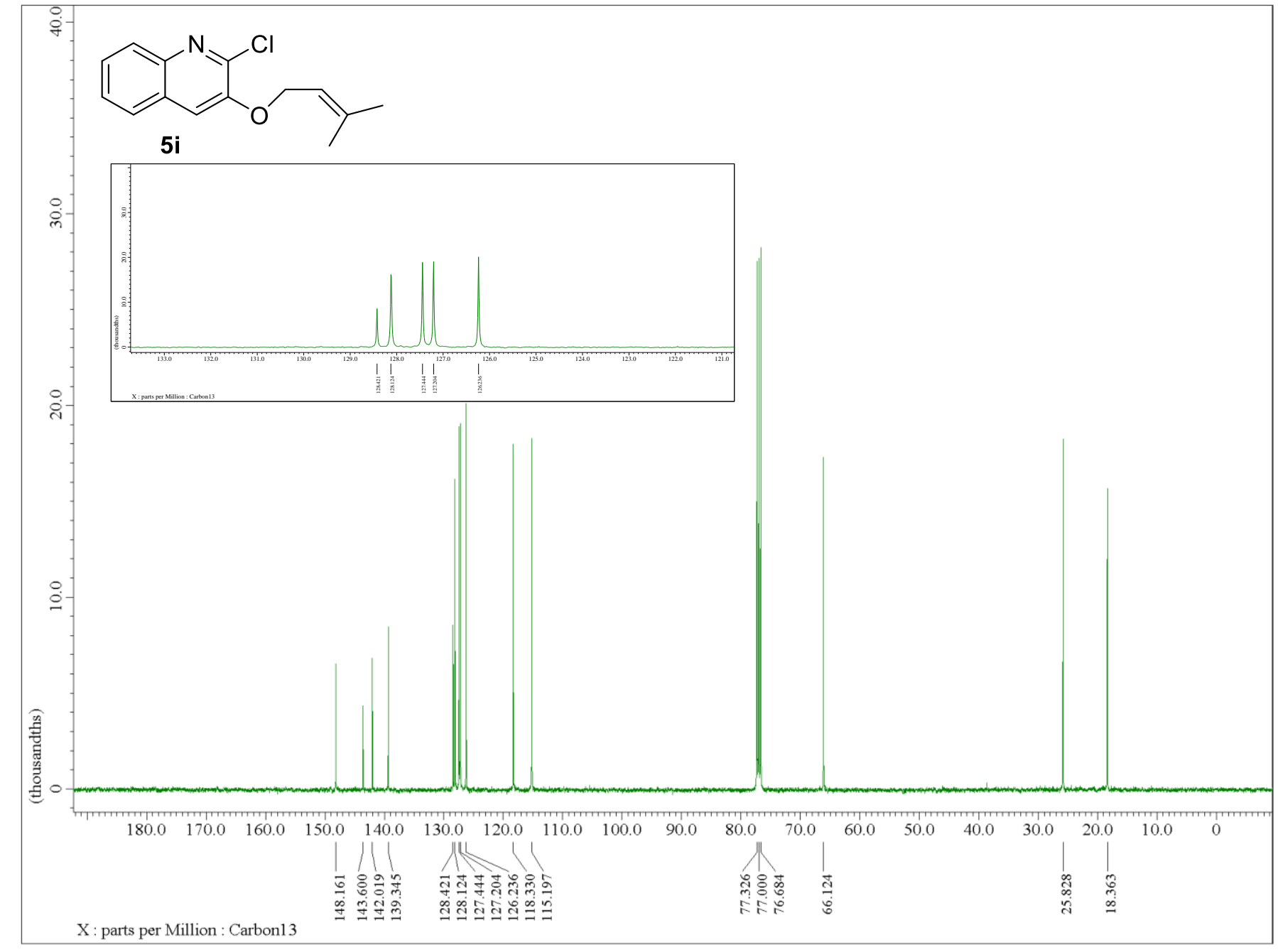

${ }^{13} \mathrm{C} \mathrm{NMR}, 100 \mathrm{MHz}, \mathrm{CDCl}_{3}$ 


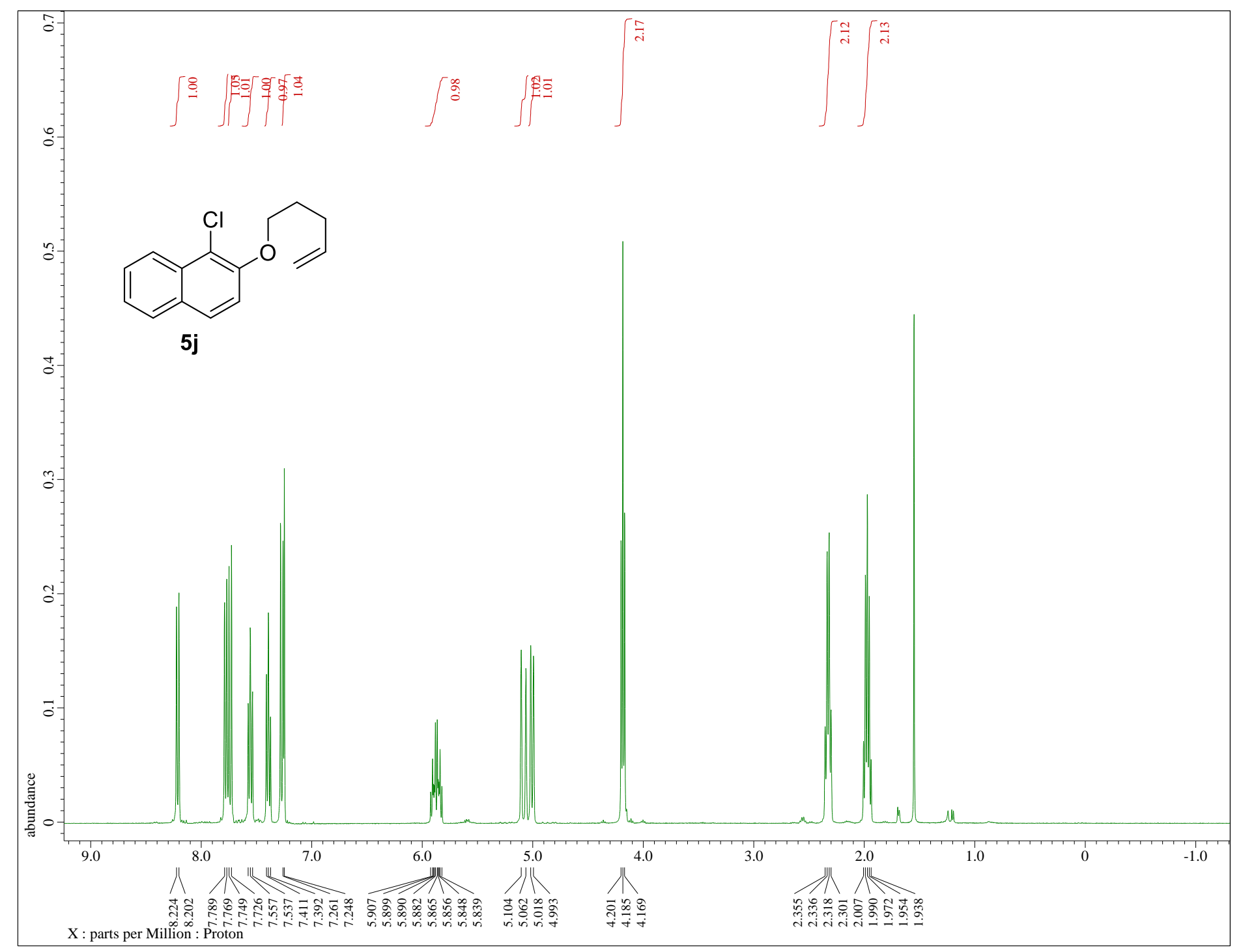

${ }^{1} \mathrm{H} \mathrm{NMR}, 400 \mathrm{MHz}, \mathrm{CDCl}_{3}$ 


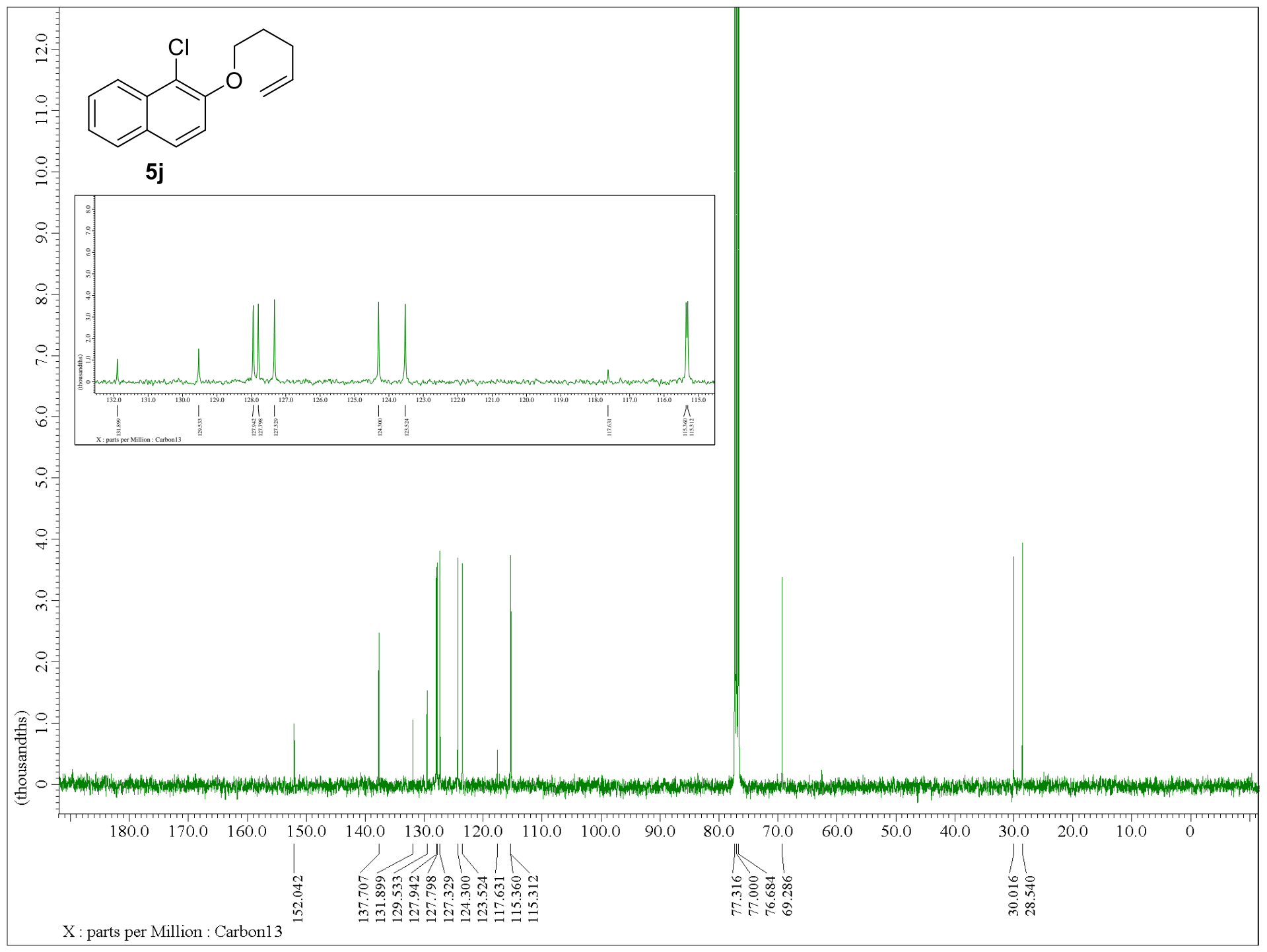

${ }^{13} \mathrm{C} \mathrm{NMR}, 100 \mathrm{MHz}, \mathrm{CDCl}_{3}$ 


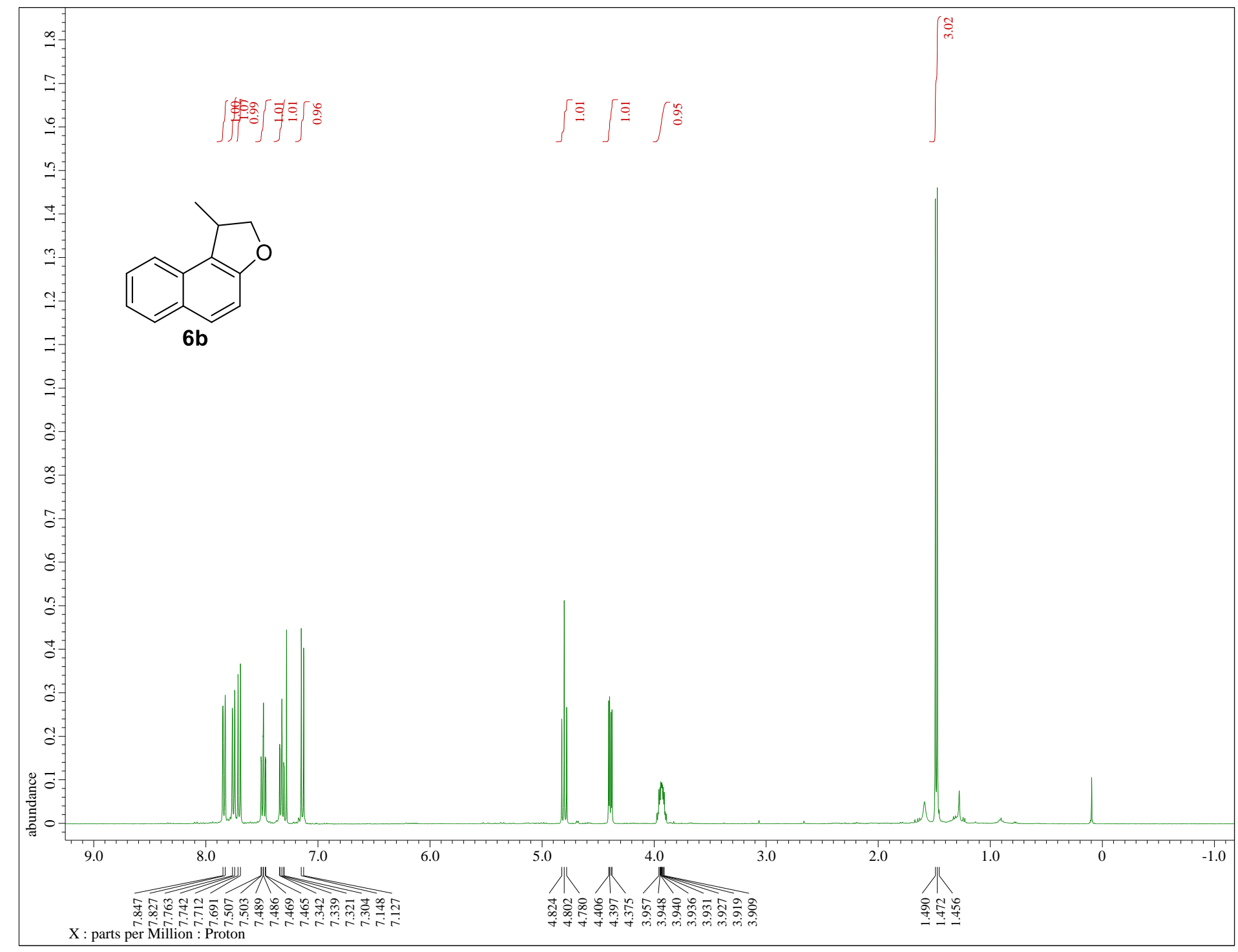

${ }^{1} \mathrm{H} \mathrm{NMR}, 400 \mathrm{MHz}, \mathrm{CDCl}_{3}$ 


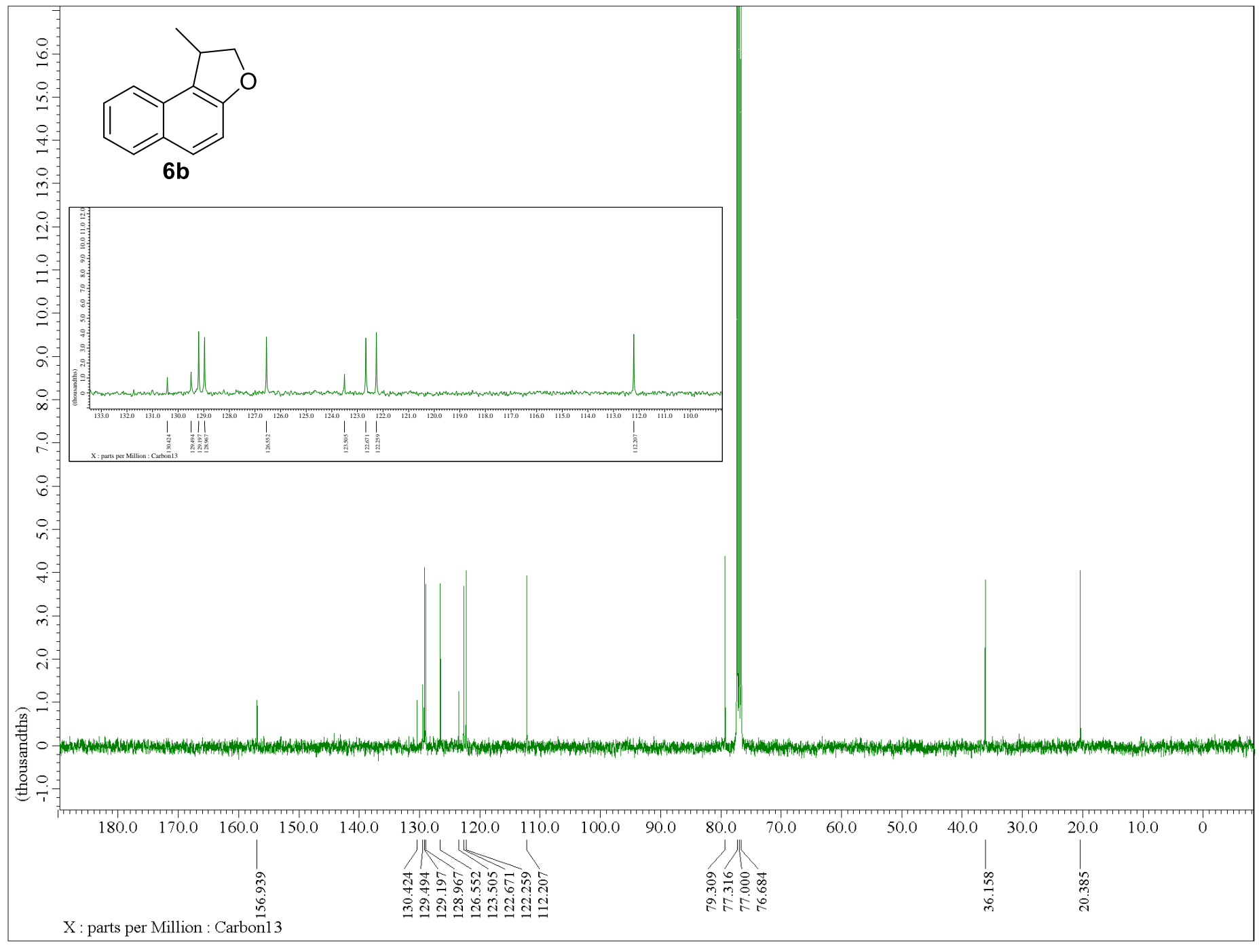

${ }^{13} \mathrm{C} \mathrm{NMR}, 100 \mathrm{MHz}, \mathrm{CDCl}_{3}$ 


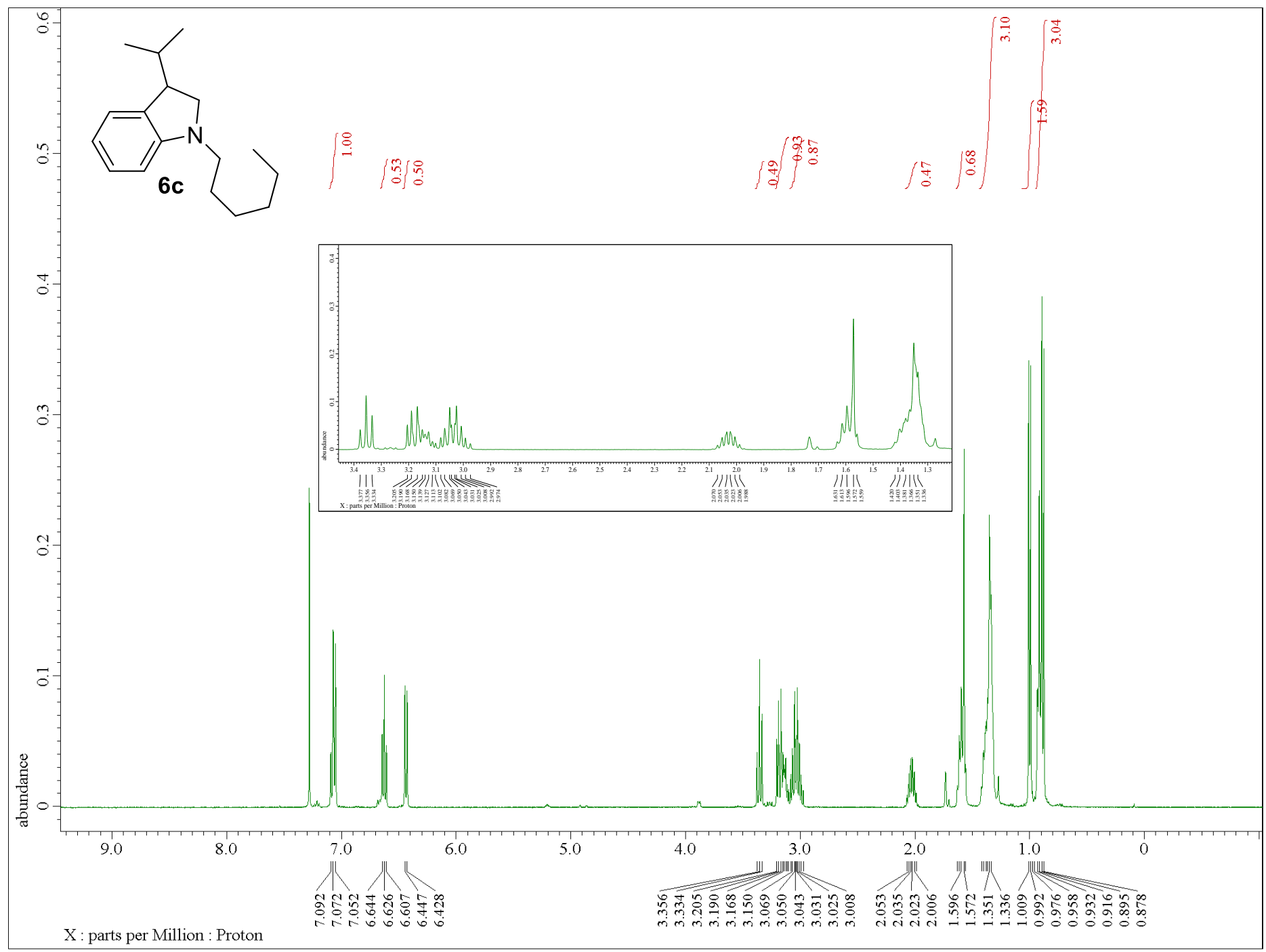

${ }^{1} \mathrm{H} \mathrm{NMR}, 400 \mathrm{MHz}, \mathrm{CDCl}_{3}$ 


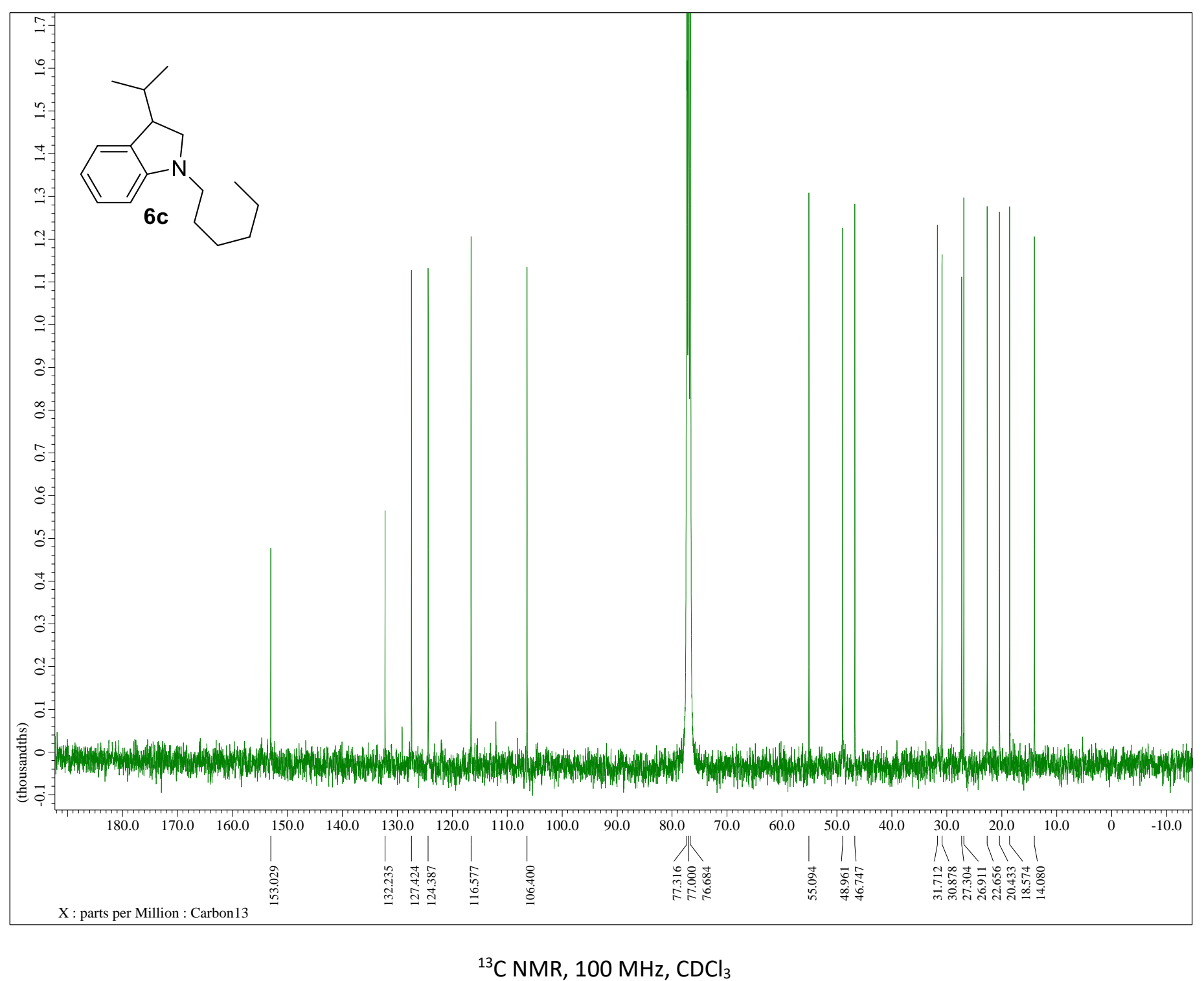




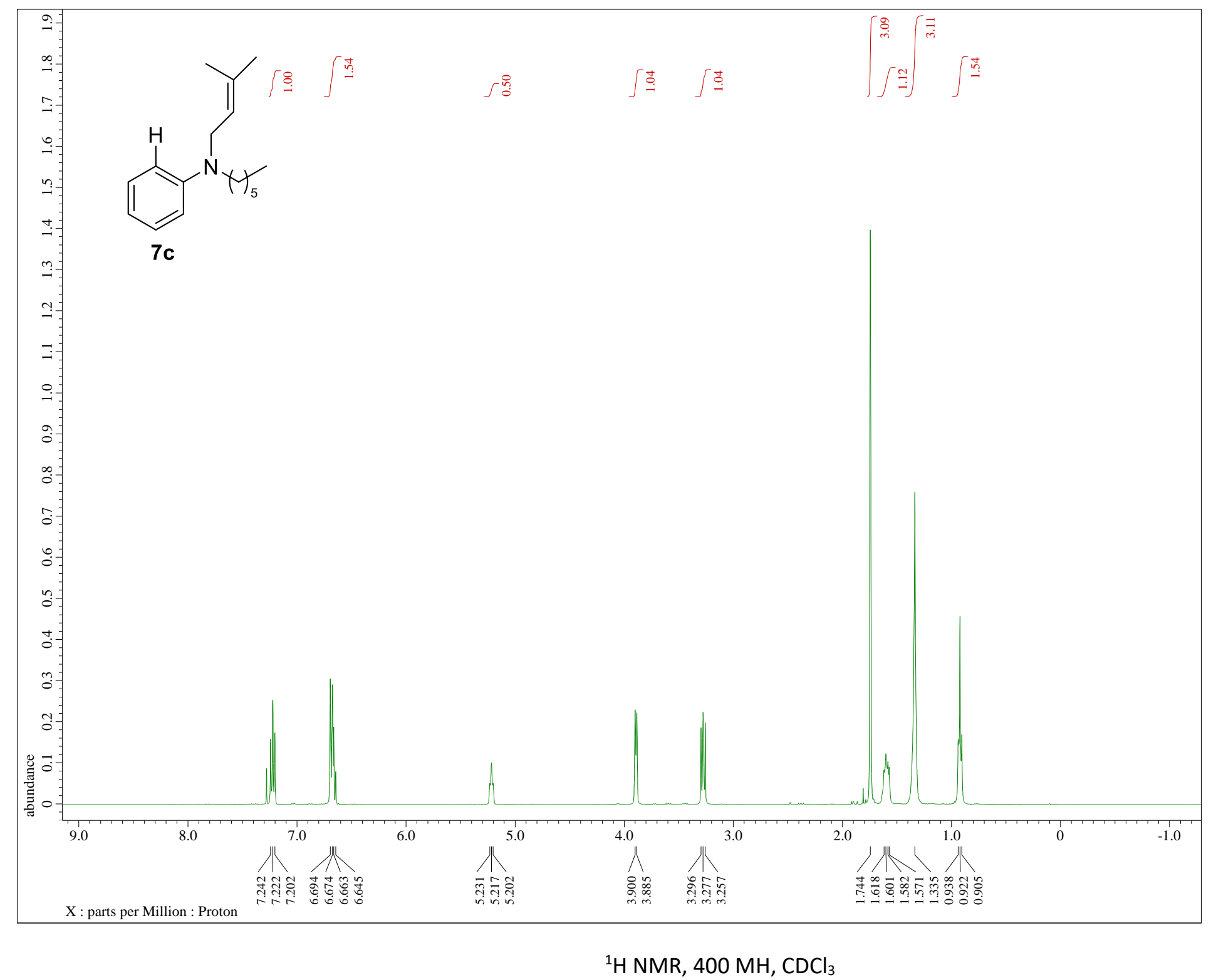




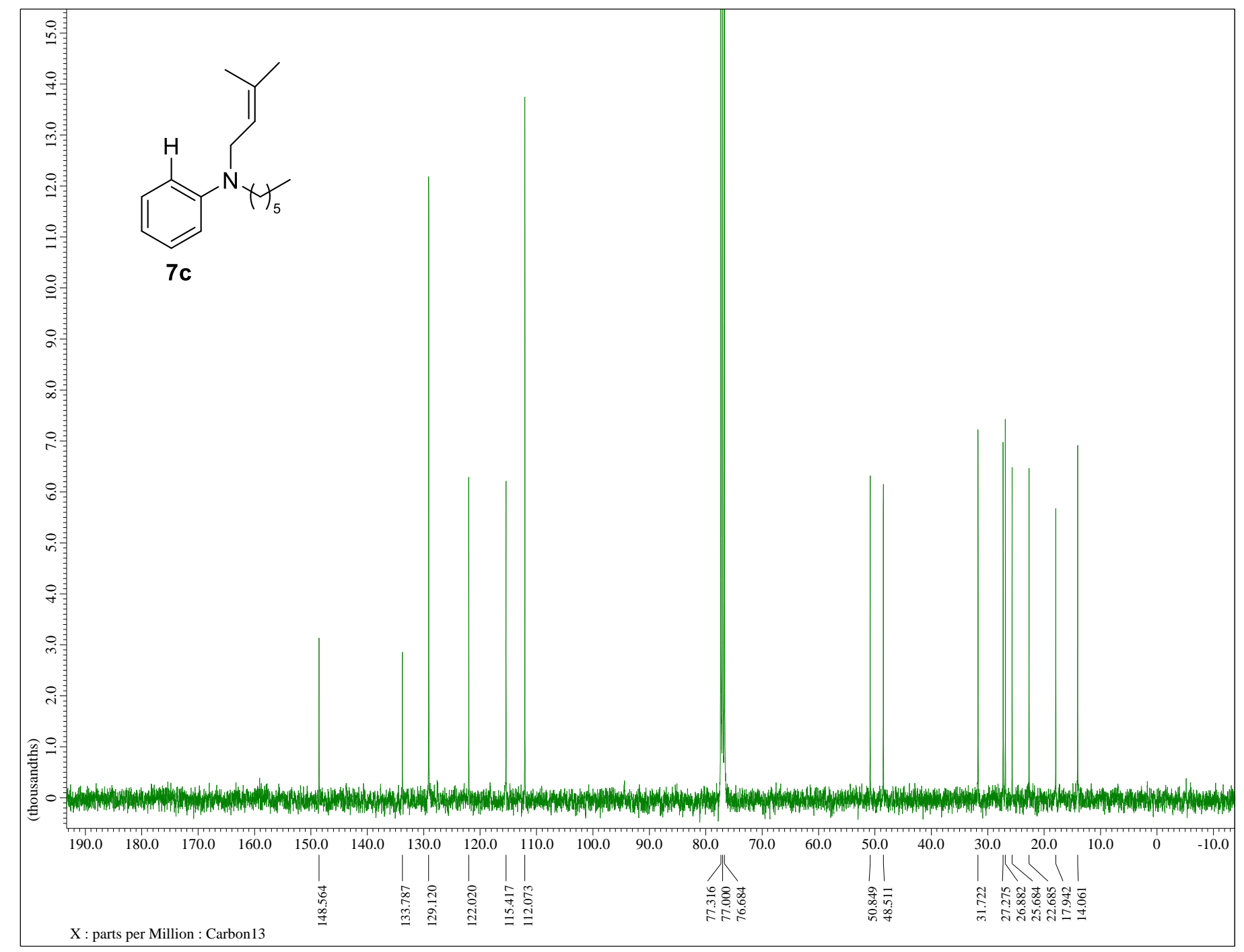

${ }^{13} \mathrm{C} \mathrm{NMR}, 100 \mathrm{MHz}, \mathrm{CDCl}_{3}$ 


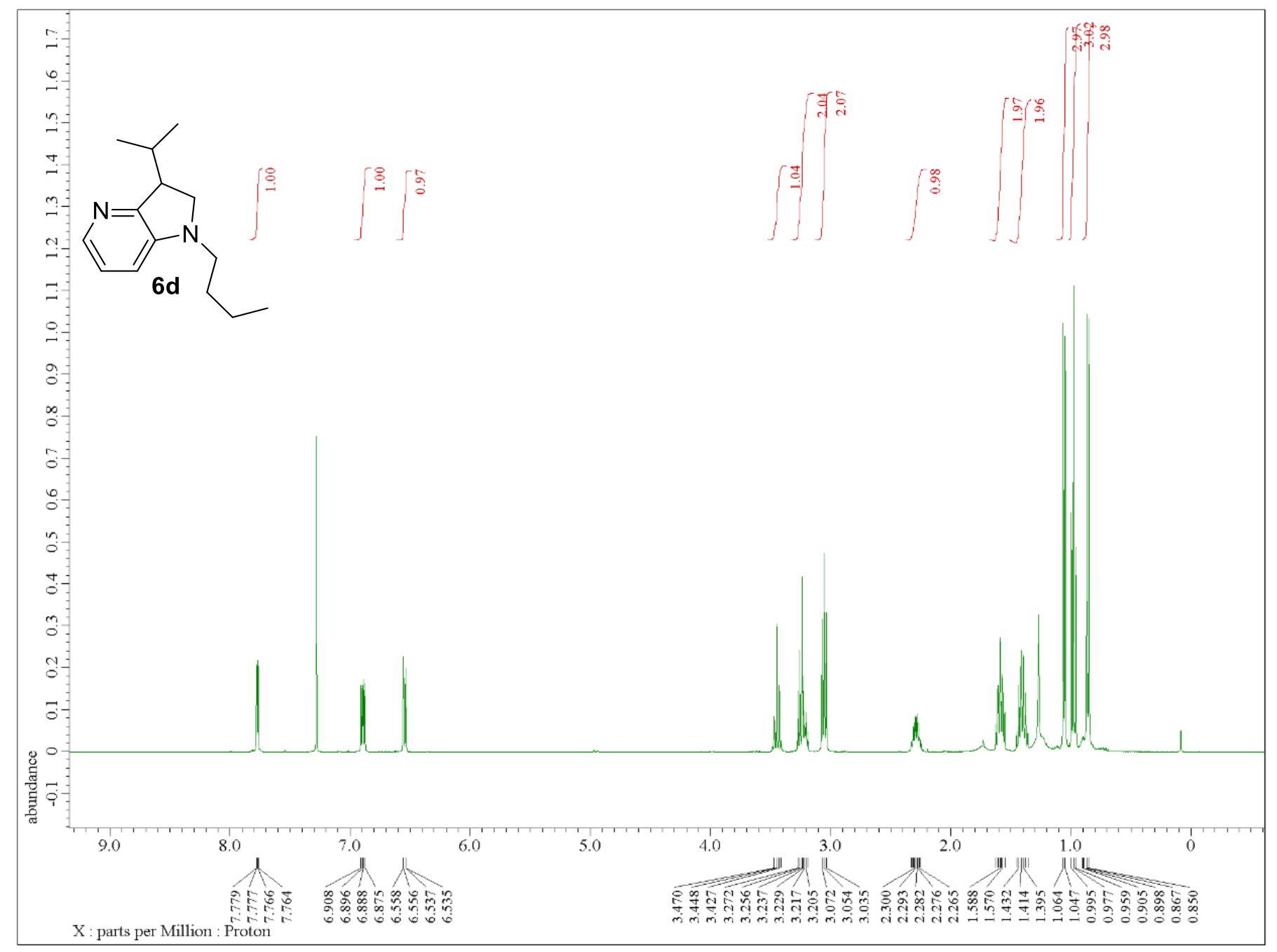

${ }^{1} \mathrm{H} \mathrm{NMR}, 400 \mathrm{MHz}, \mathrm{CDCl}_{3}$ 


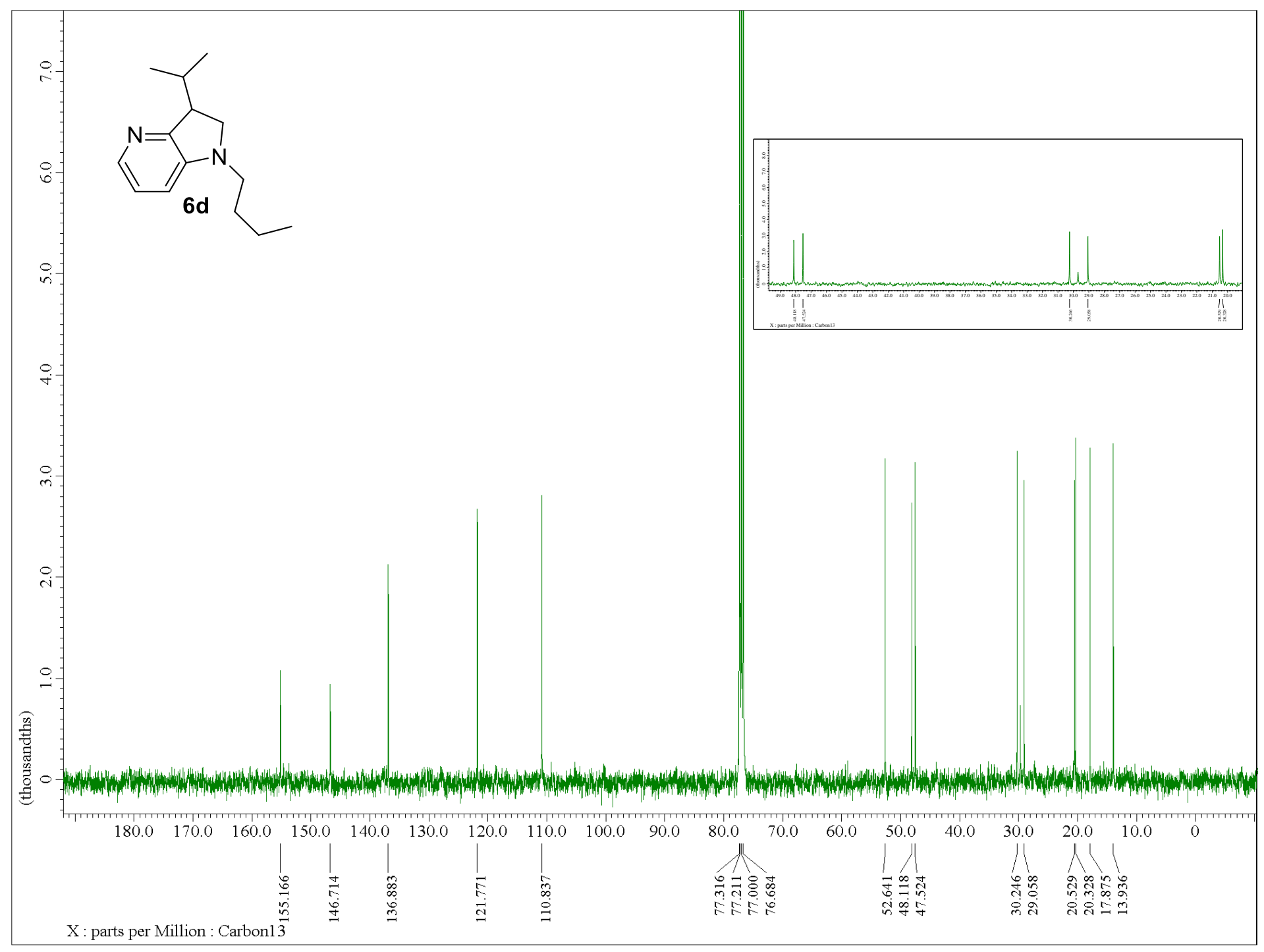

${ }^{13} \mathrm{C} \mathrm{NMR}, 100 \mathrm{MHz}, \mathrm{CDCl}_{3}$ 


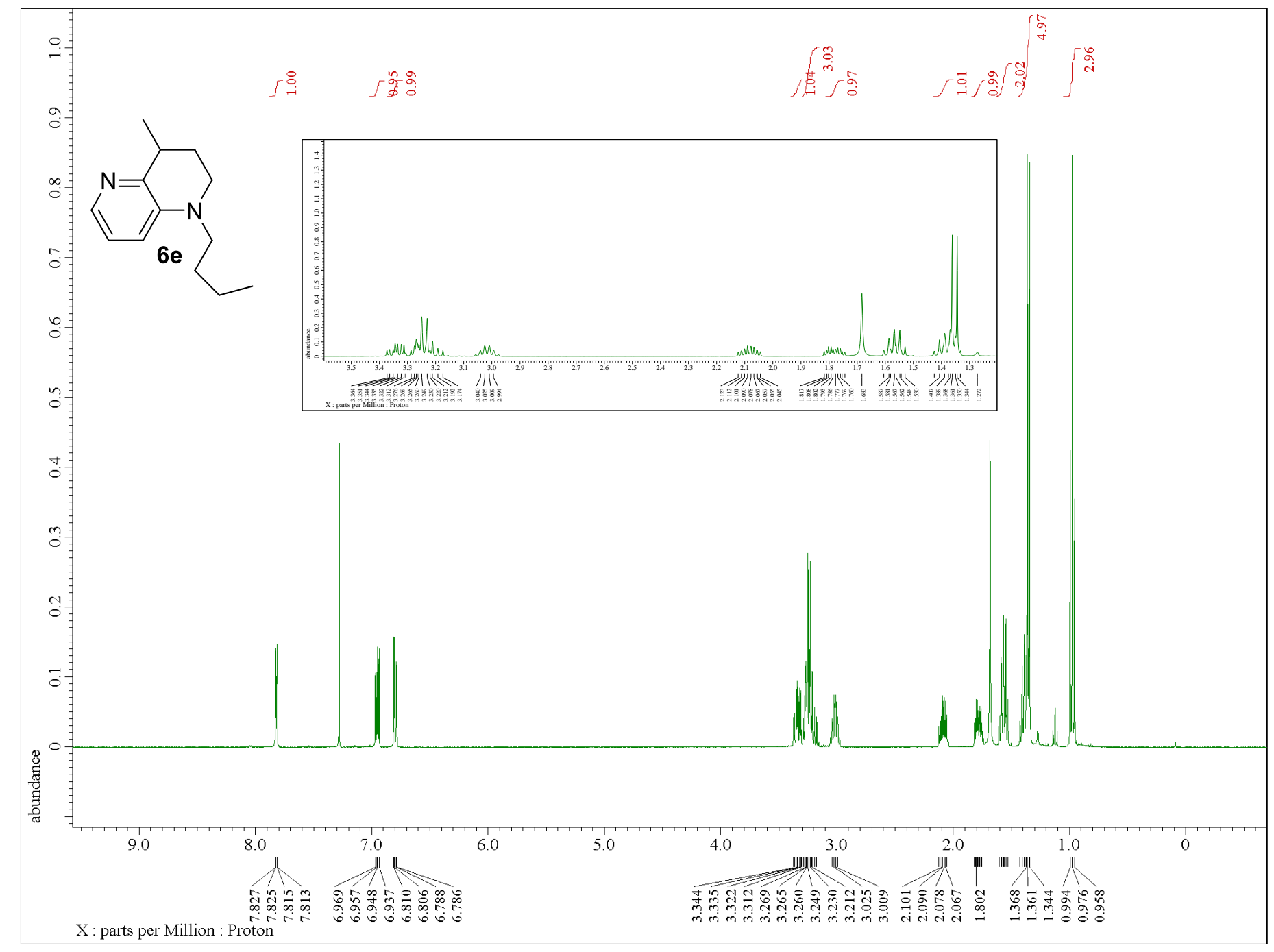

${ }^{1} \mathrm{H} \mathrm{NMR}, 400 \mathrm{MHz}, \mathrm{CDCl}_{3}$ 


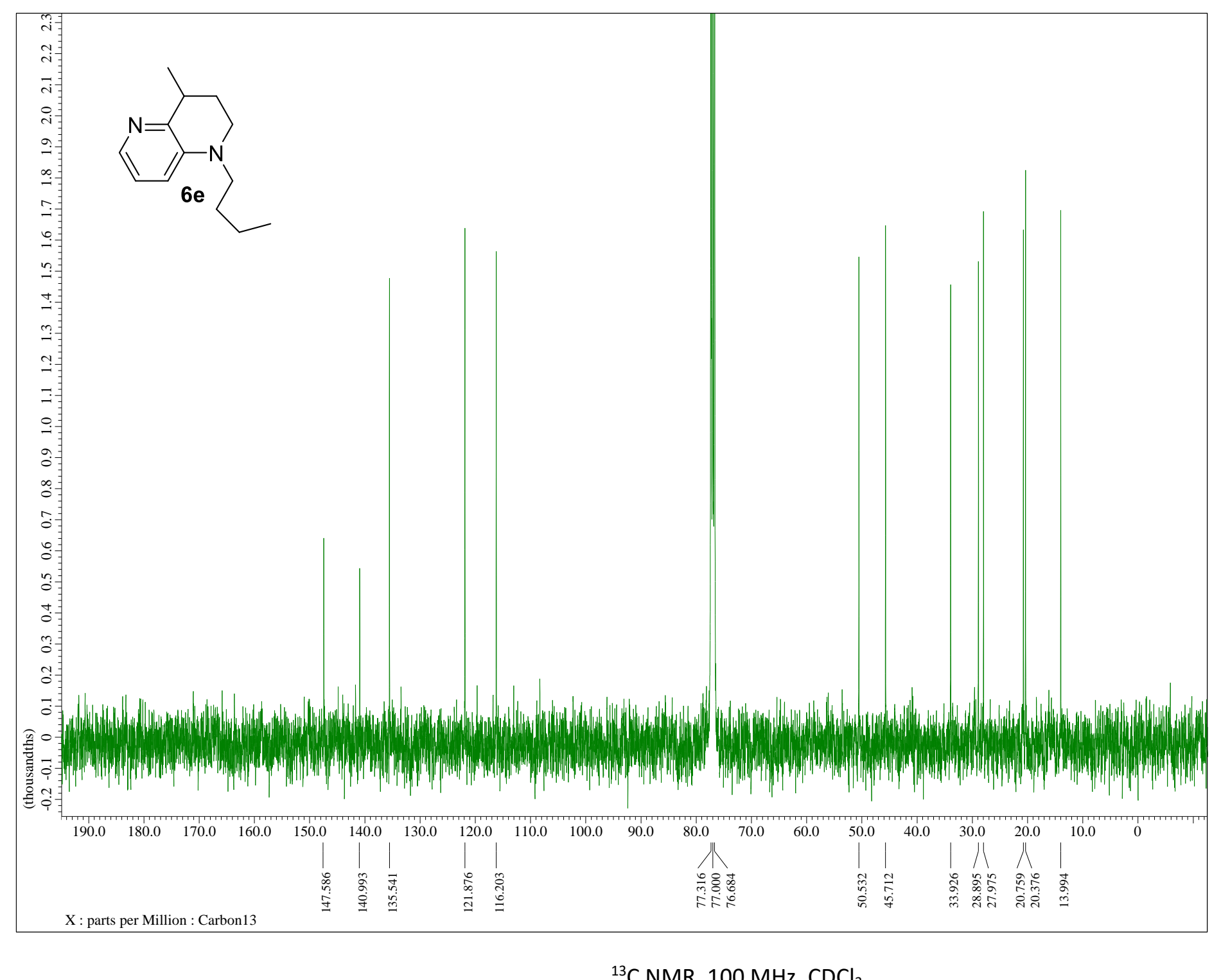




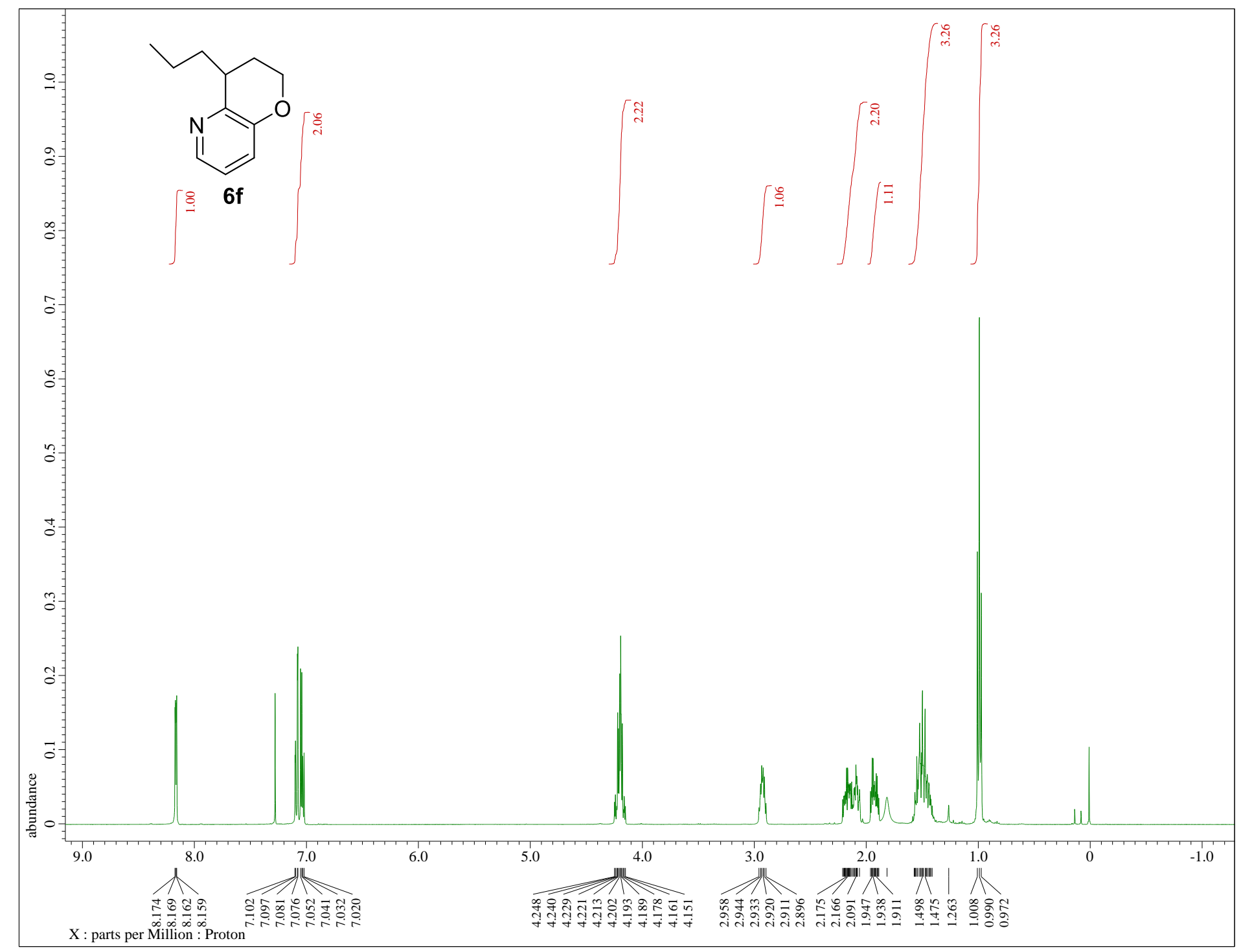

${ }^{1} \mathrm{H} \mathrm{NMR}, 400 \mathrm{MHz}, \mathrm{CDCl}_{3}$ 


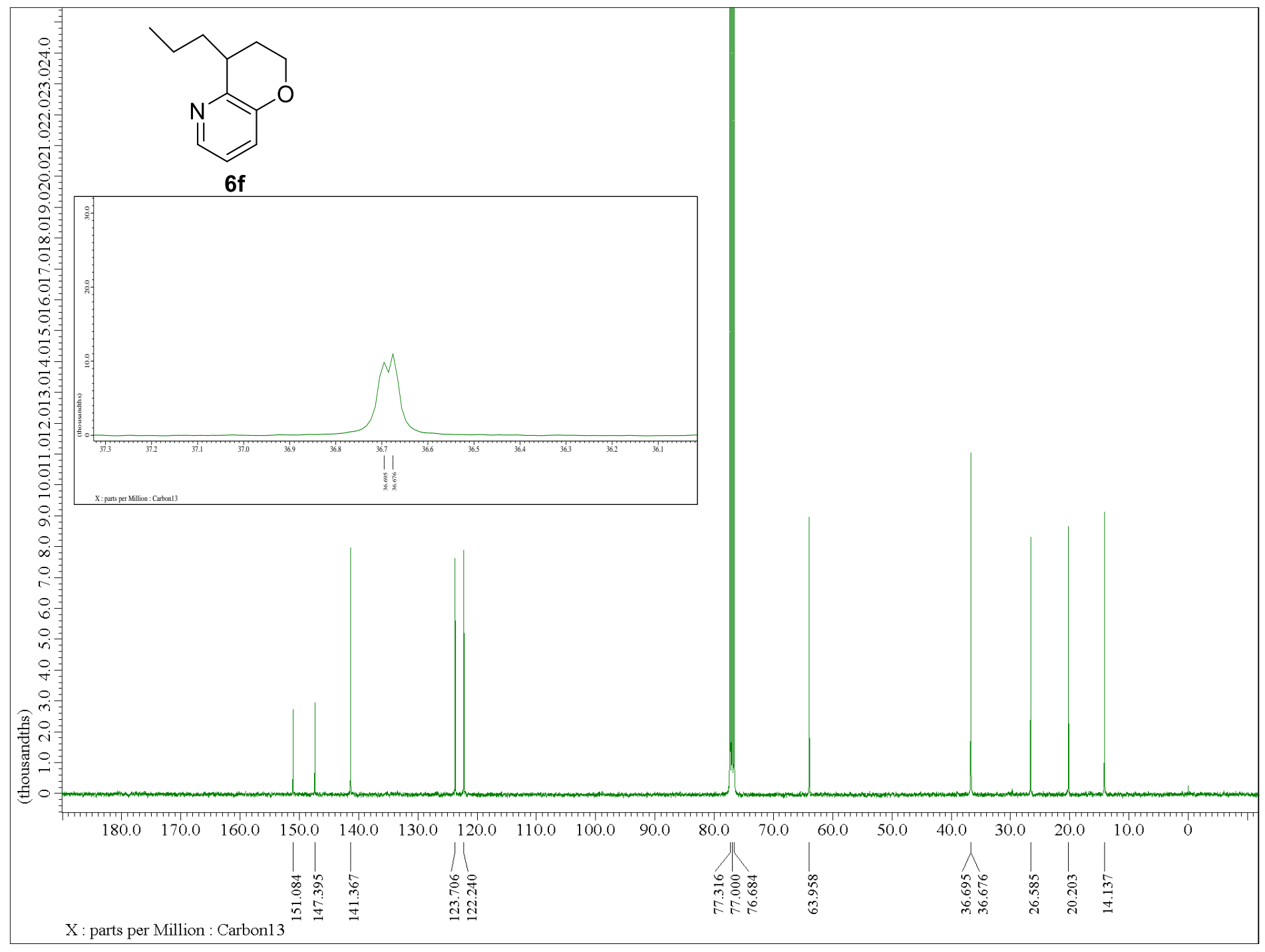

${ }^{13} \mathrm{C} \mathrm{NMR}, 100 \mathrm{MHz}, \mathrm{CDCl}_{3}$ 


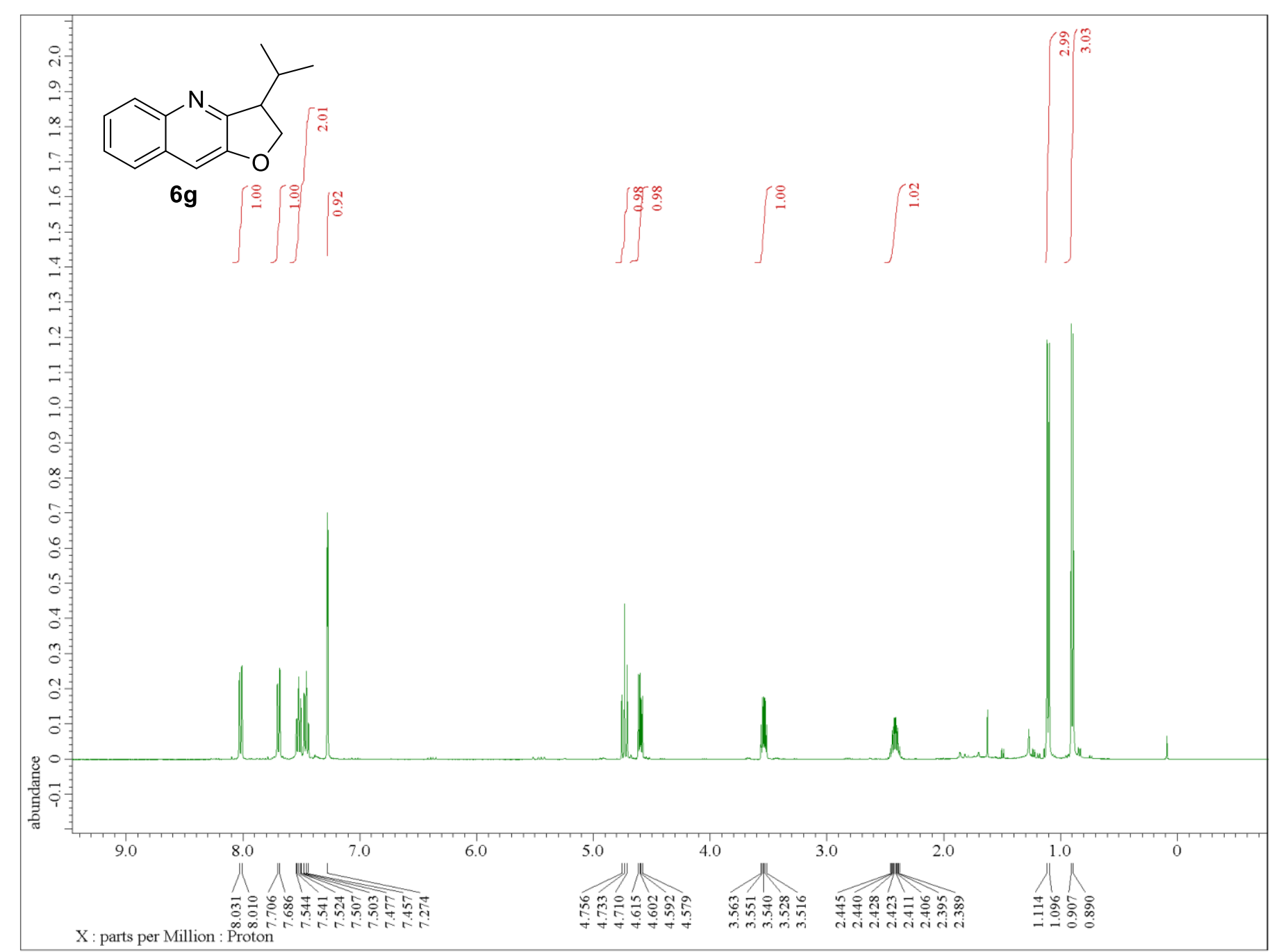

${ }^{1} \mathrm{H} \mathrm{NMR}, 400 \mathrm{MHz}, \mathrm{CDCl}_{3}$ 


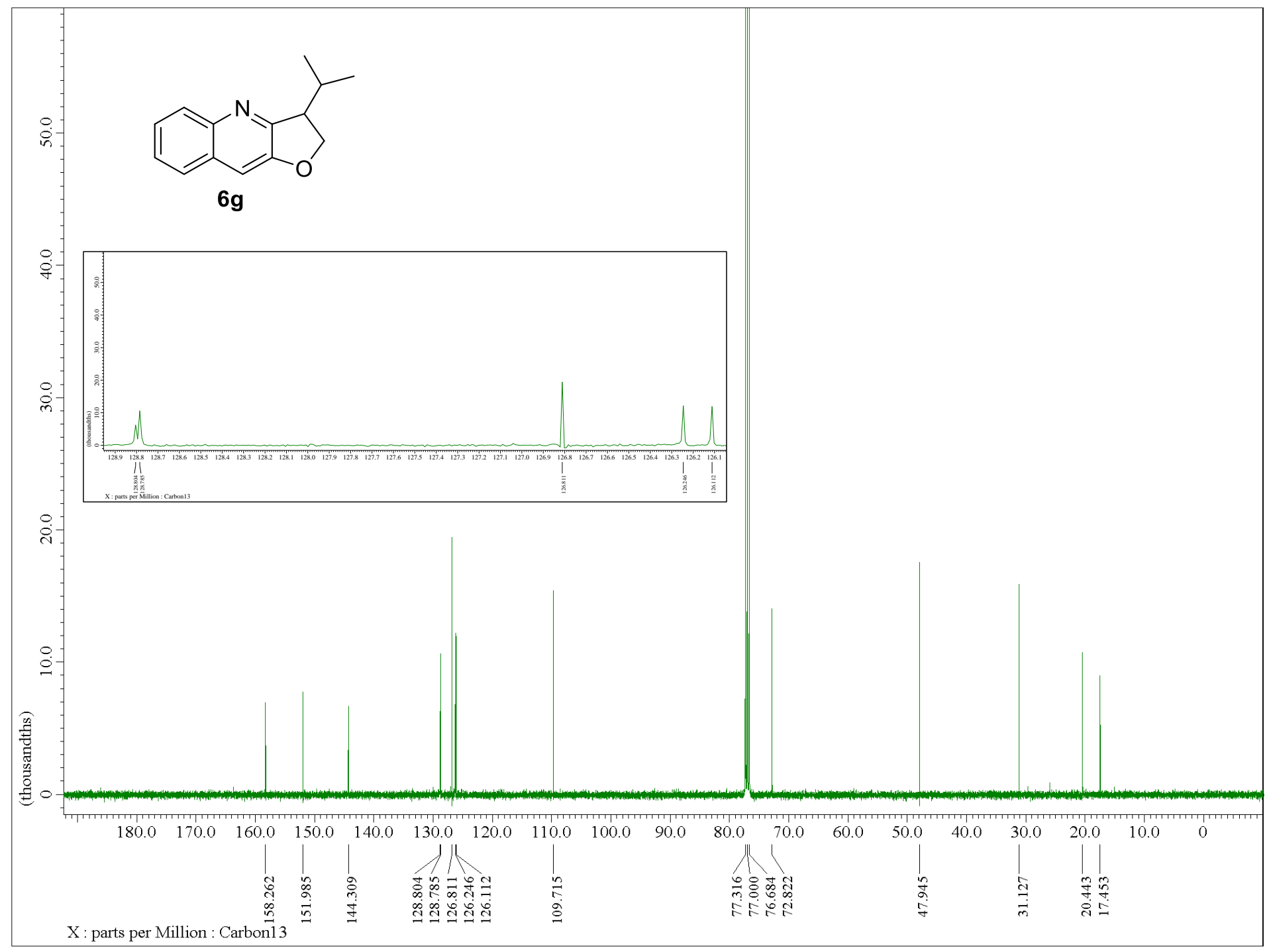

${ }^{13} \mathrm{C} \mathrm{NMR}, 100 \mathrm{MHz}, \mathrm{CDCl}_{3}$ 


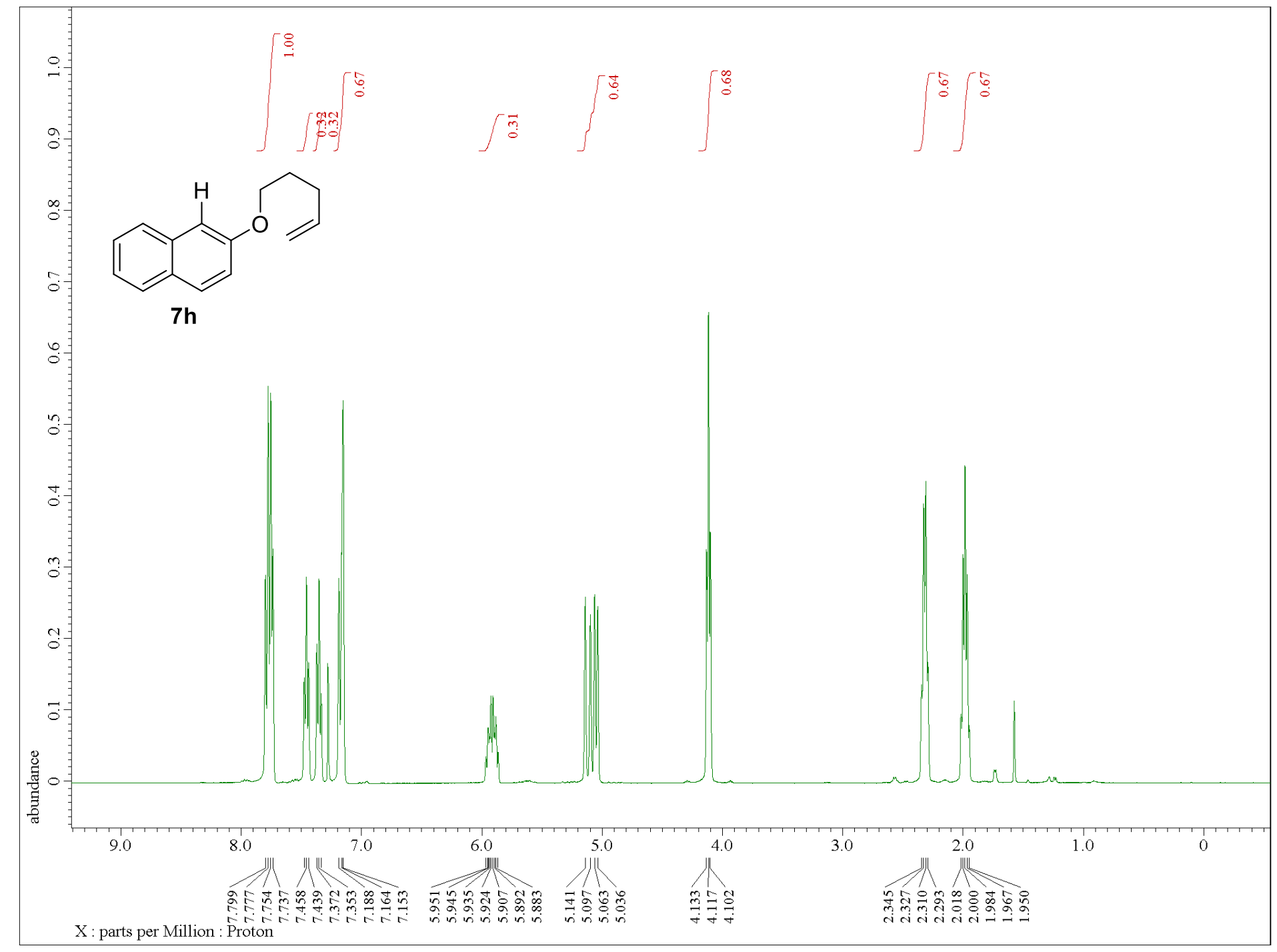

${ }^{1} \mathrm{H} \mathrm{NMR}, 400 \mathrm{MHz}, \mathrm{CDCl}_{3}$ 


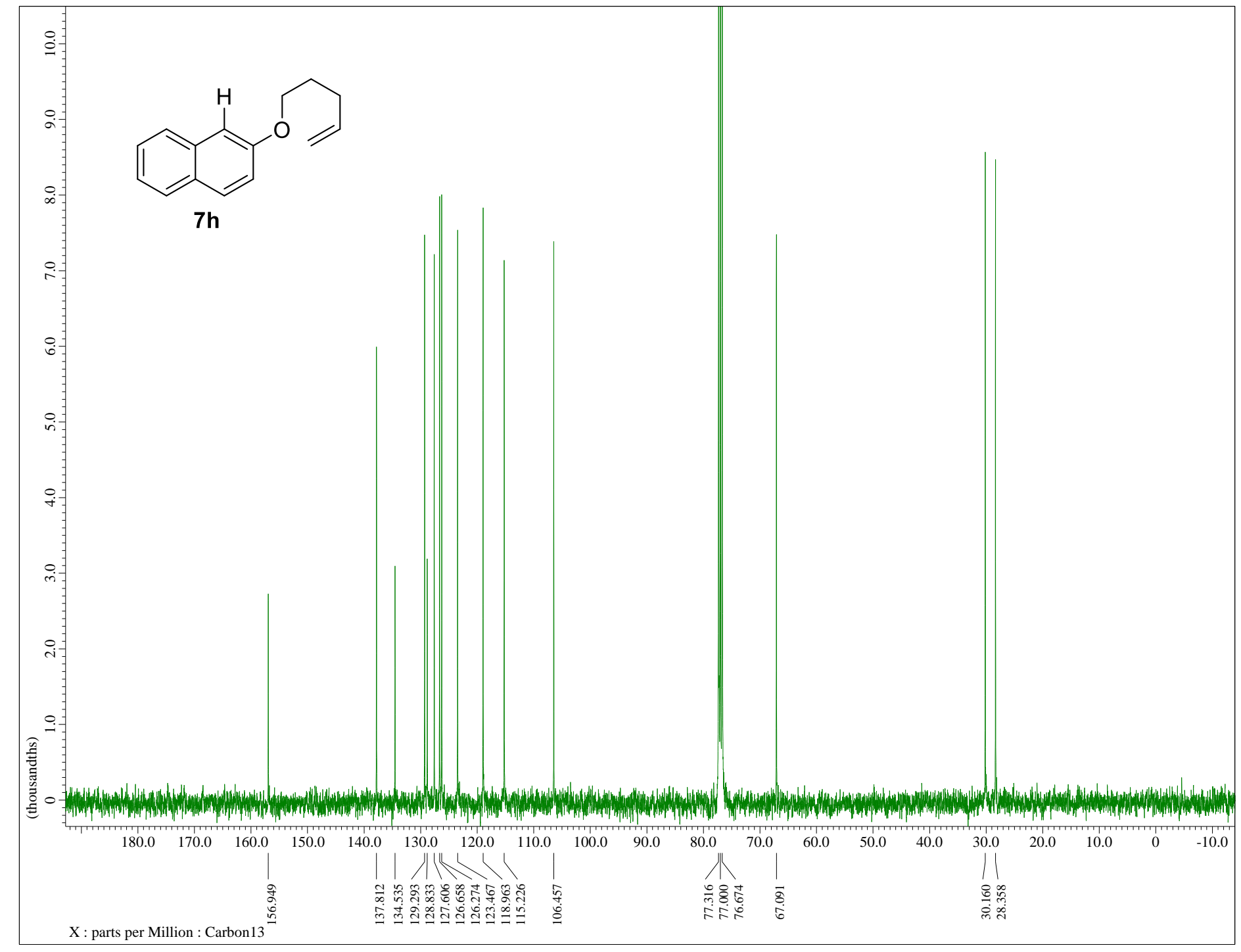

${ }^{13} \mathrm{C} \mathrm{NMR}, 100 \mathrm{MHz}, \mathrm{CDCl}_{3}$ 


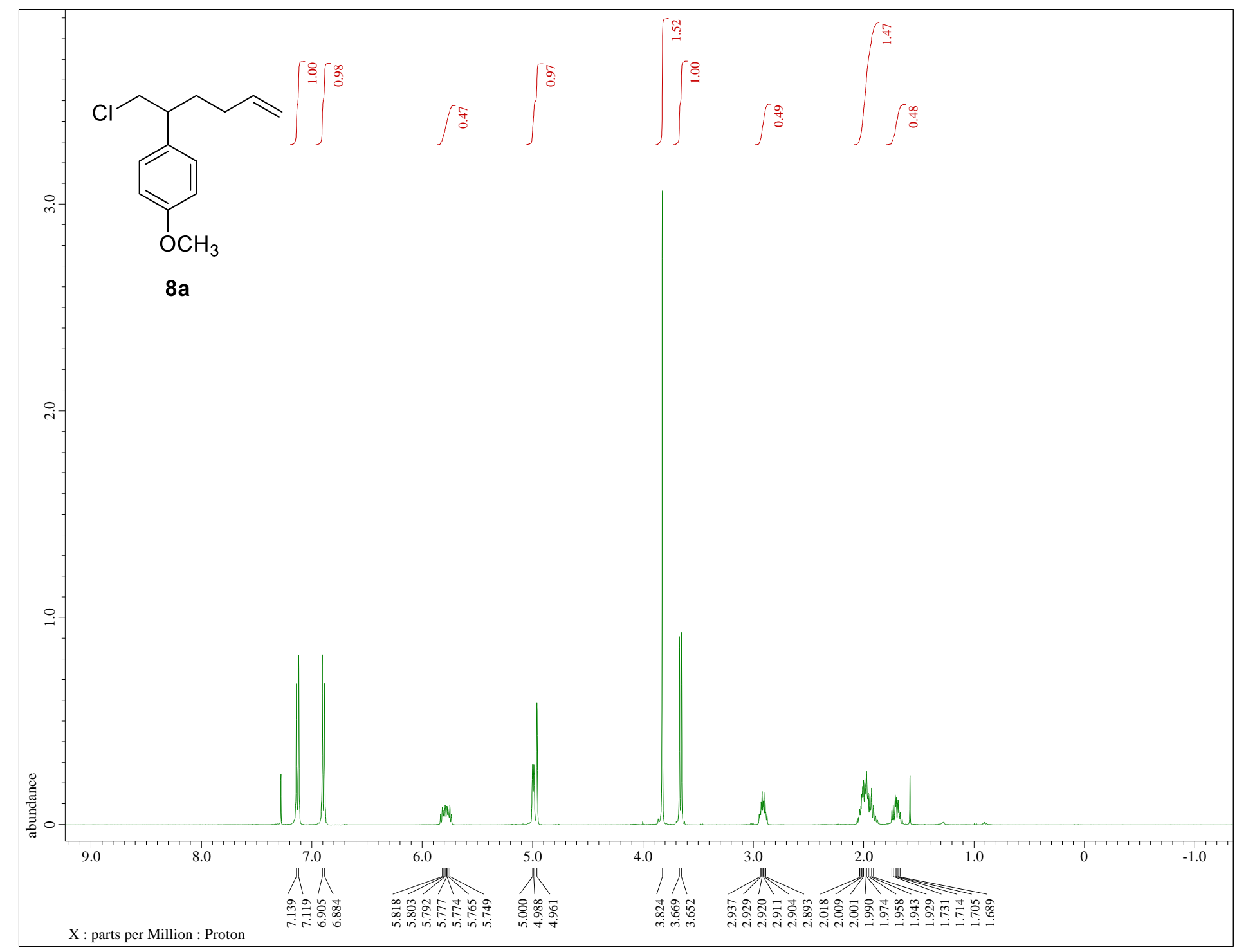

${ }^{1} \mathrm{H} \mathrm{NMR}, 400 \mathrm{MHz}, \mathrm{CDCl}_{3}$ 


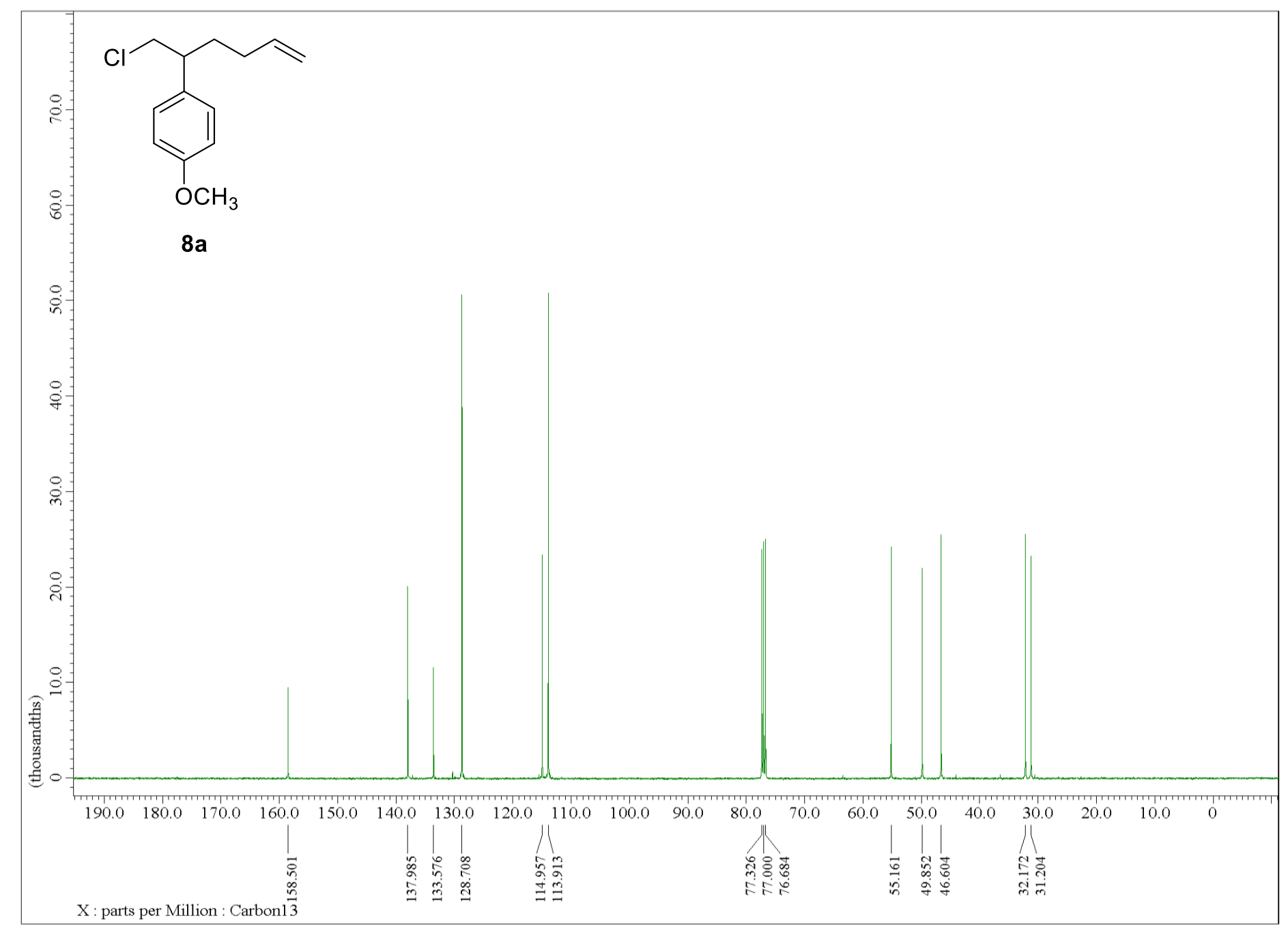

${ }^{13} \mathrm{C} \mathrm{NMR}, 100 \mathrm{MHz}, \mathrm{CDCl}_{3}$ 


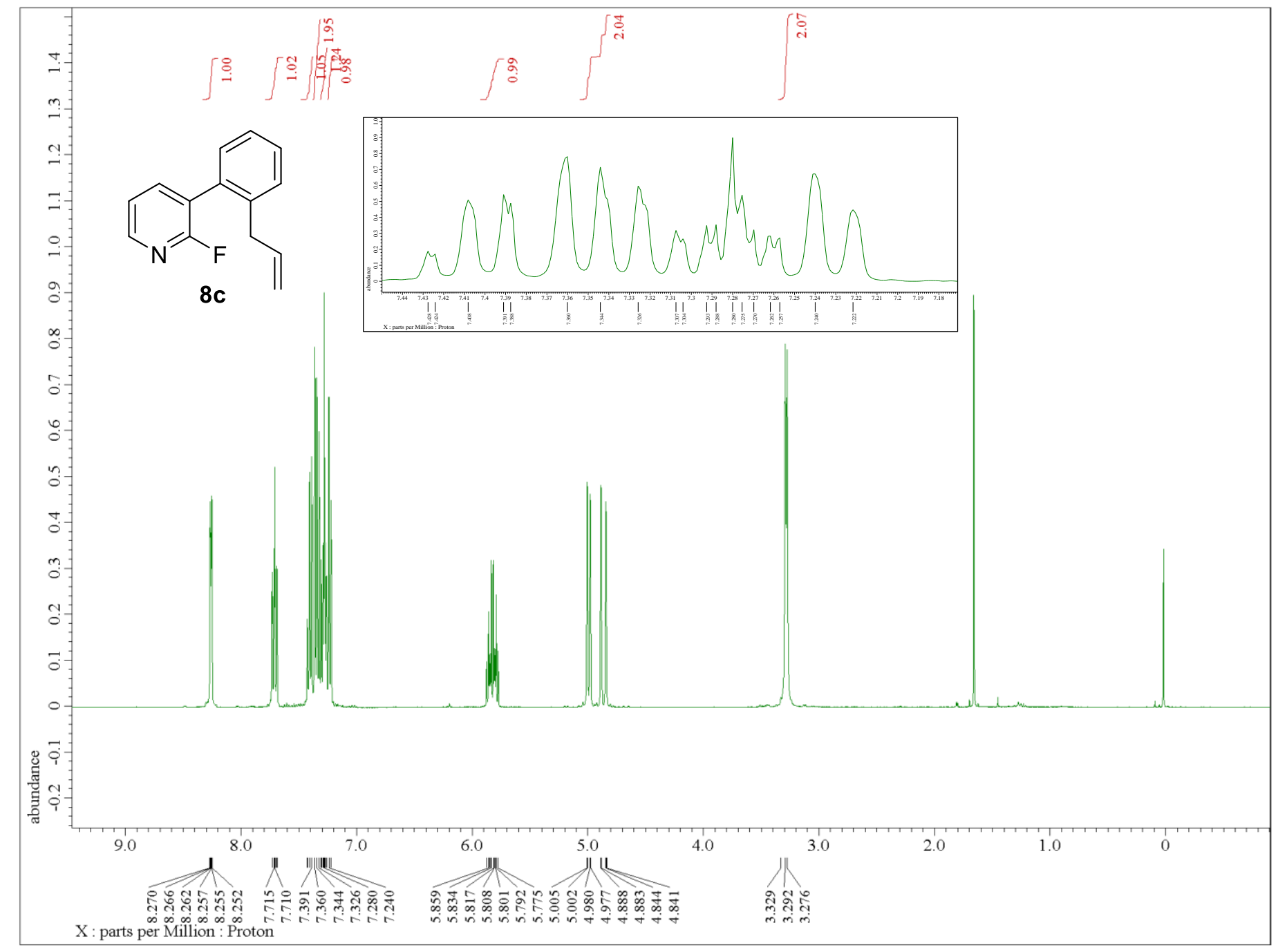

${ }^{1} \mathrm{H} \mathrm{NMR}, 400 \mathrm{MHz}, \mathrm{CDCl}_{3}$ 


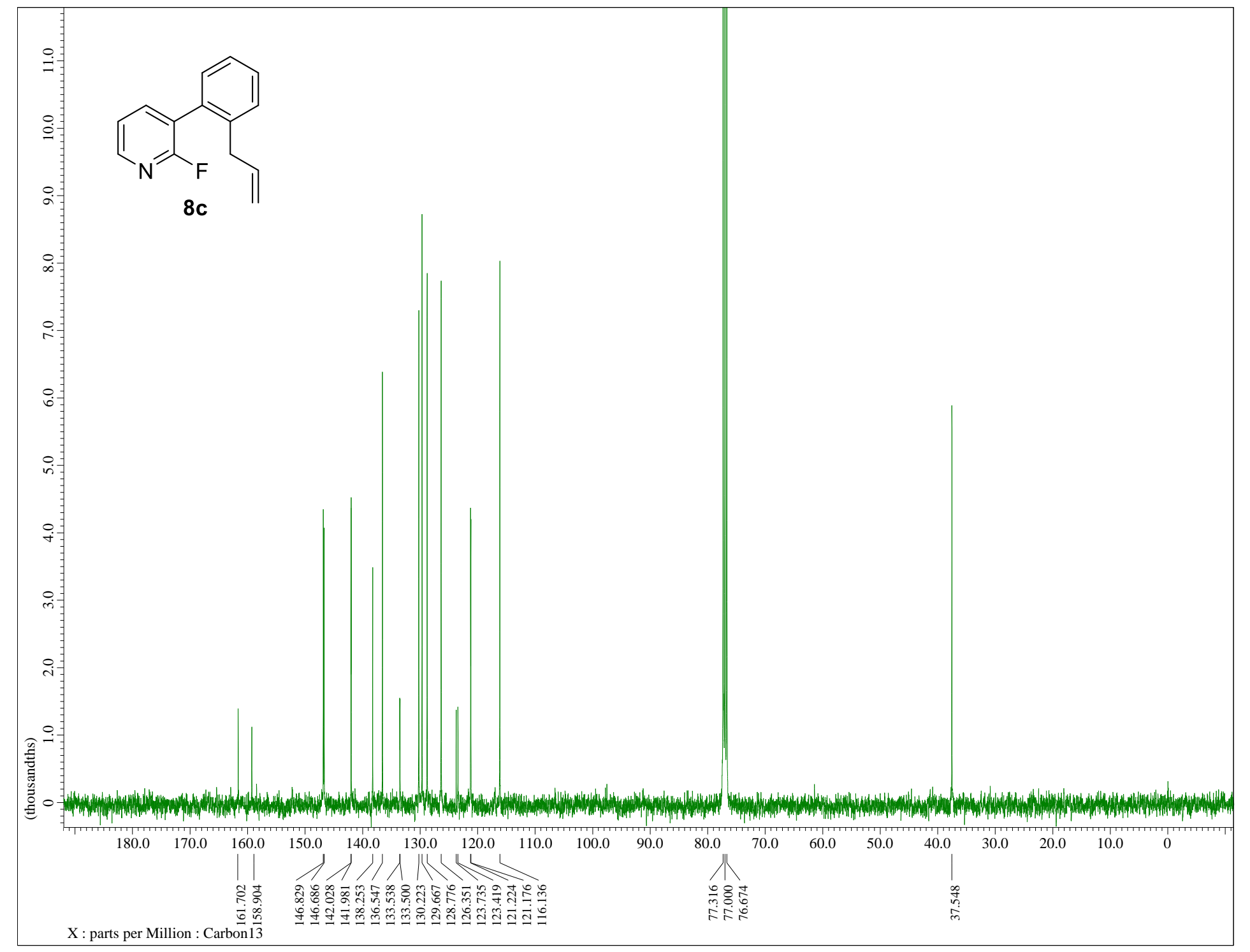

${ }^{13} \mathrm{C} \mathrm{NMR}, 100 \mathrm{MHz}, \mathrm{CDCl}_{3}$ 


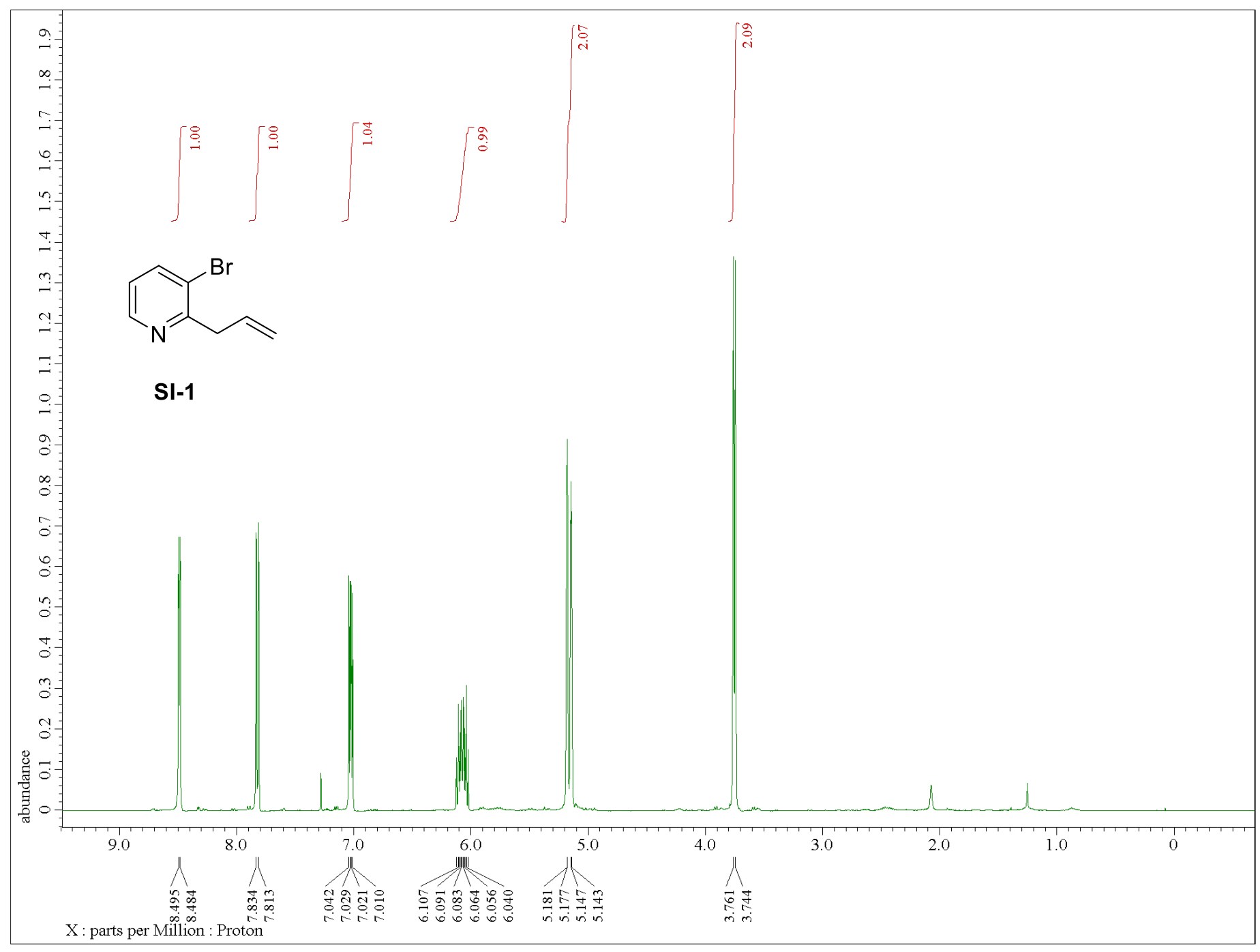

${ }^{1} \mathrm{H} \mathrm{NMR}, 400 \mathrm{MHz}, \mathrm{CDCl}_{3}$ 


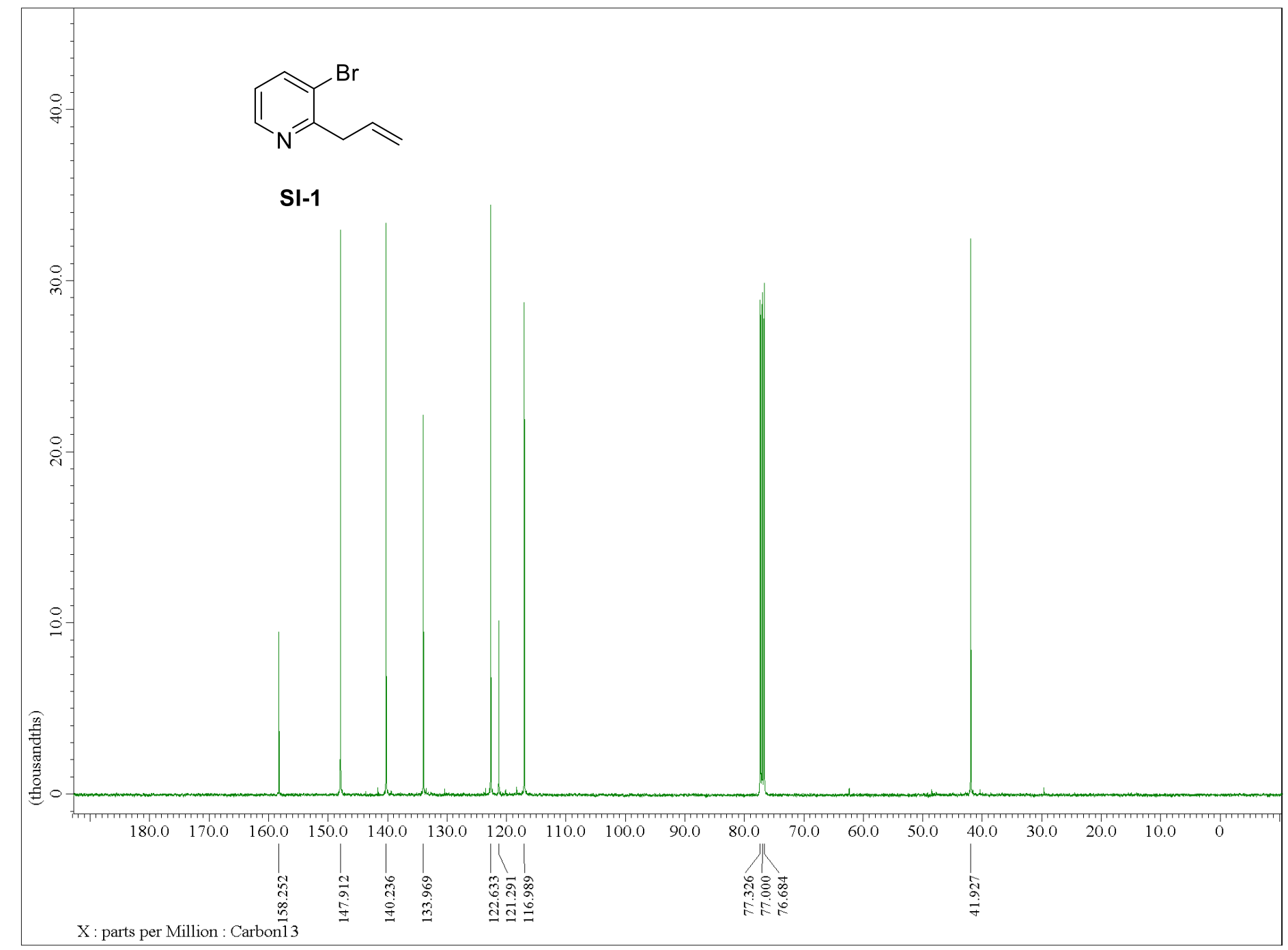

${ }^{13} \mathrm{C} \mathrm{NMR}, 100 \mathrm{MHz}, \mathrm{CDCl}_{3}$ 


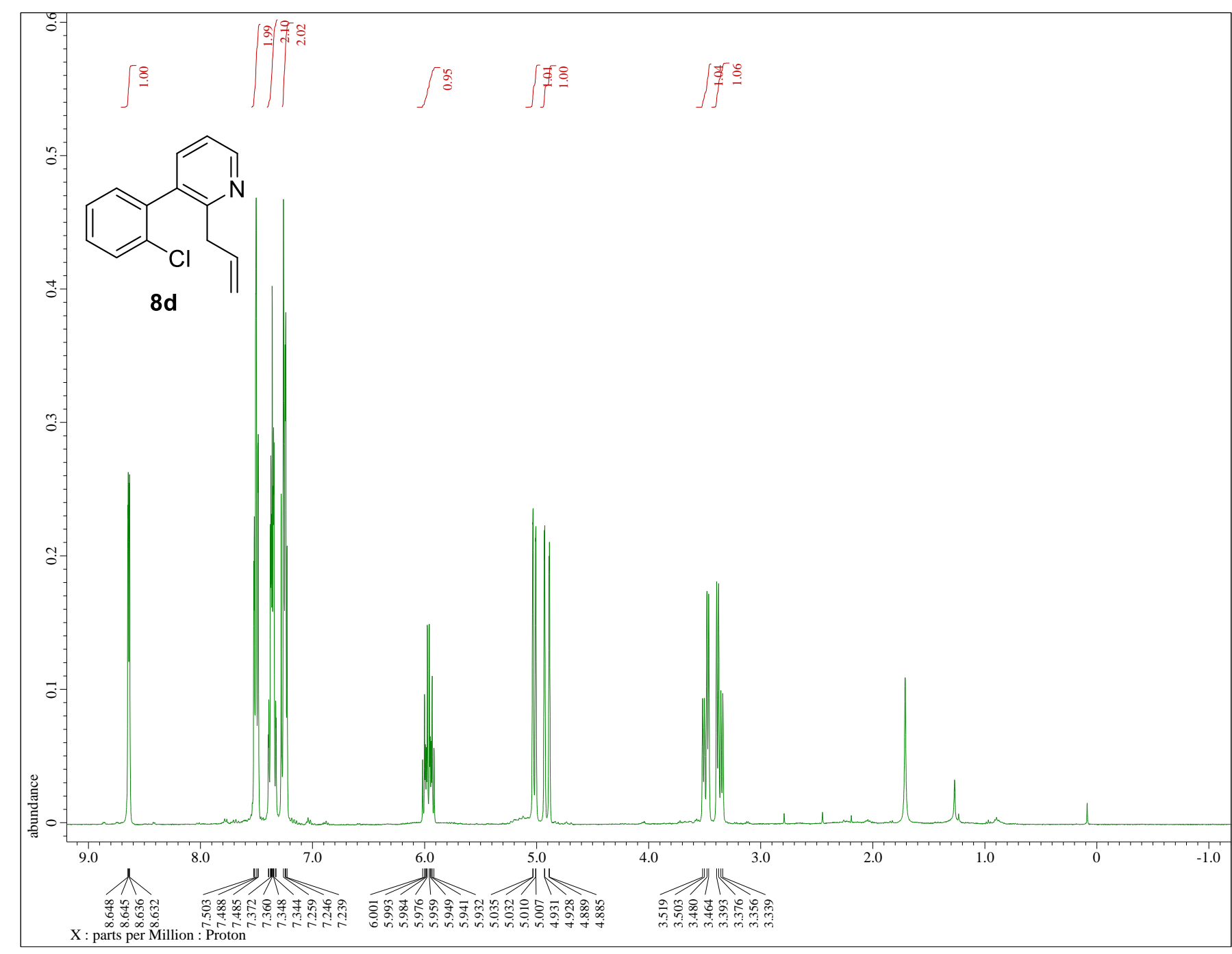

${ }^{1} \mathrm{H} \mathrm{NMR}, 400 \mathrm{MHz}, \mathrm{CDCl}_{3}$ 


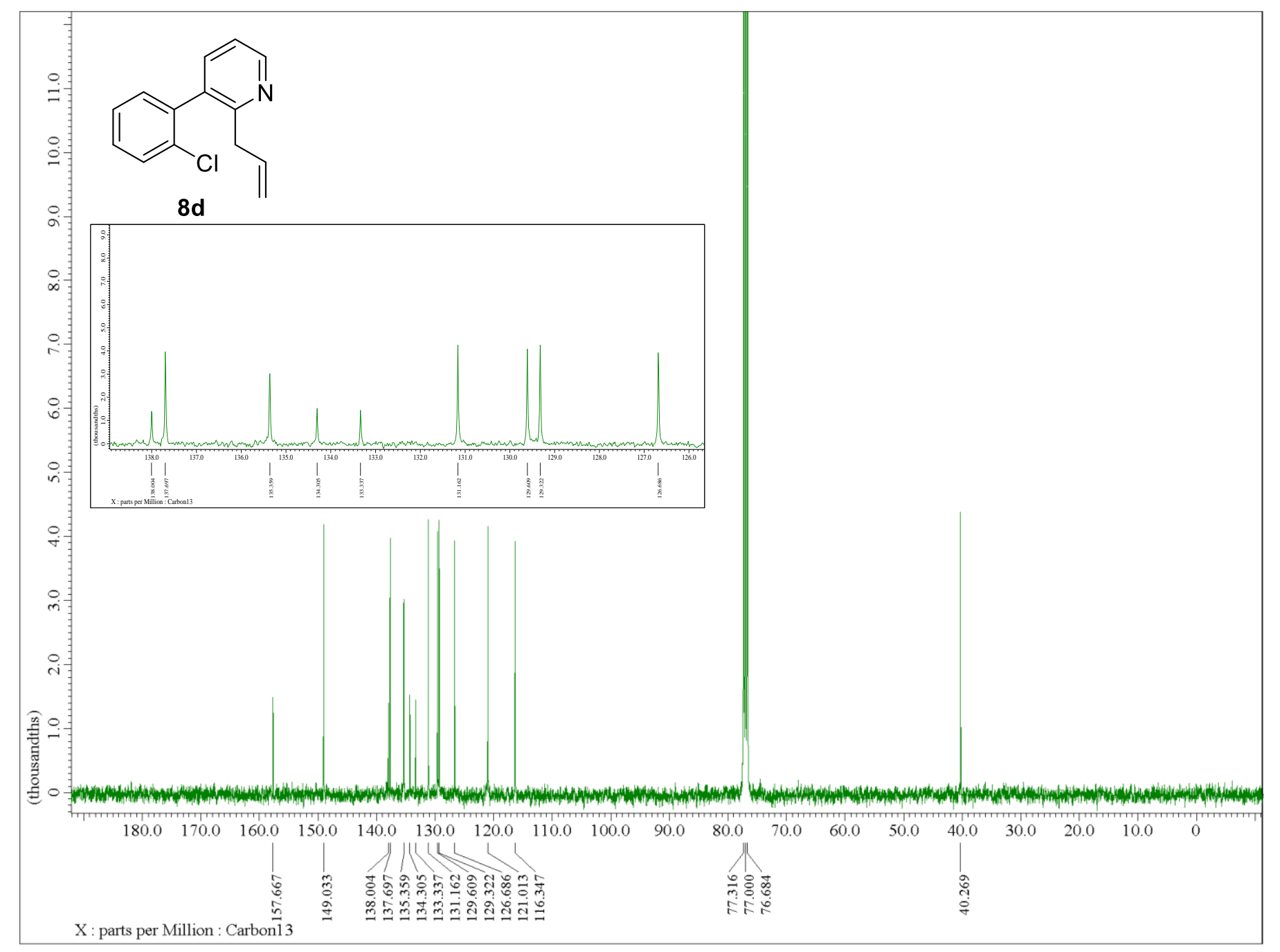

${ }^{13} \mathrm{C} \mathrm{NMR}, 100 \mathrm{MHz}, \mathrm{CDCl}_{3}$ 


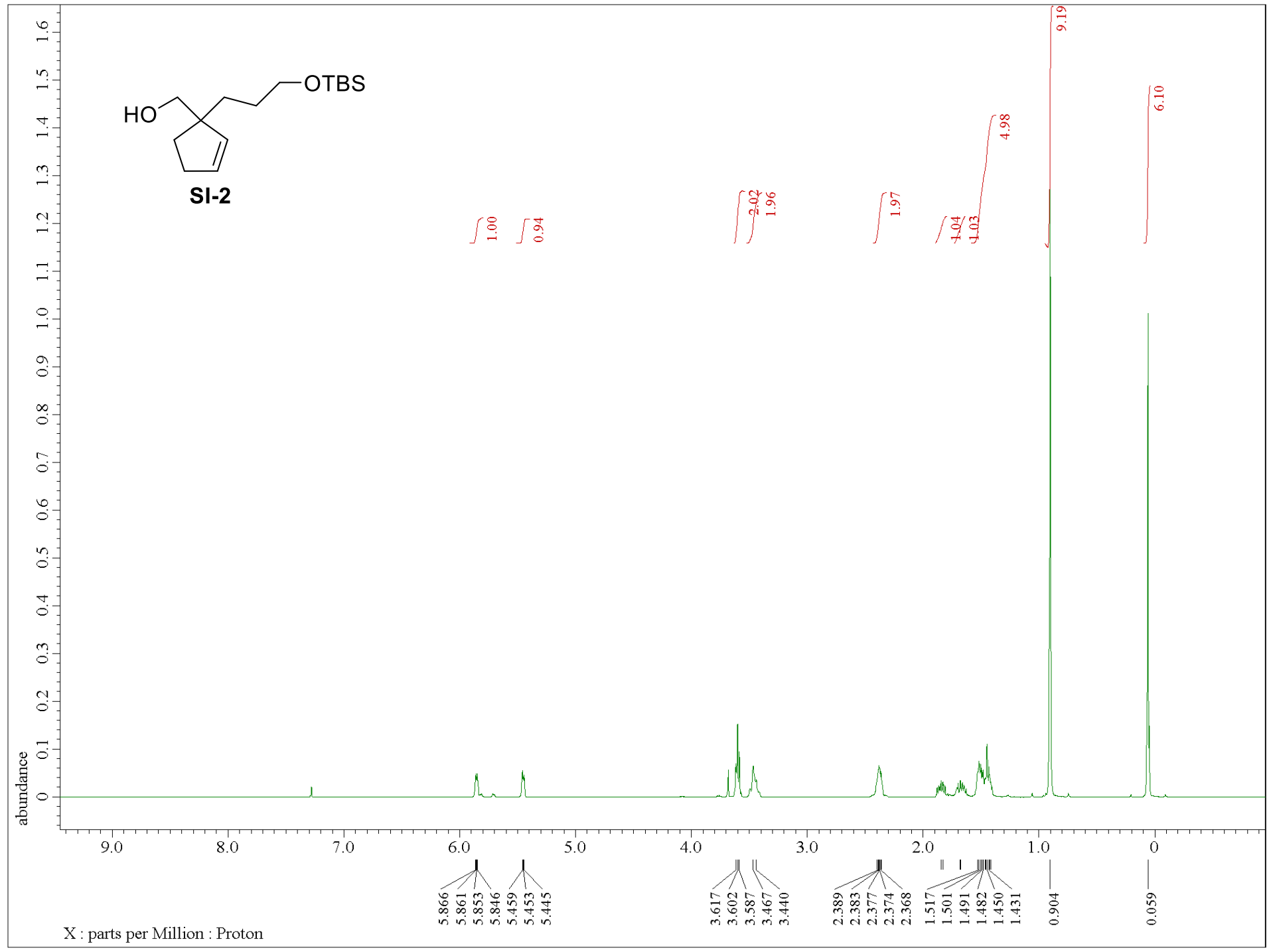

${ }^{1} \mathrm{H} \mathrm{NMR}, 400 \mathrm{MHz}, \mathrm{CDCl}_{3}$ 


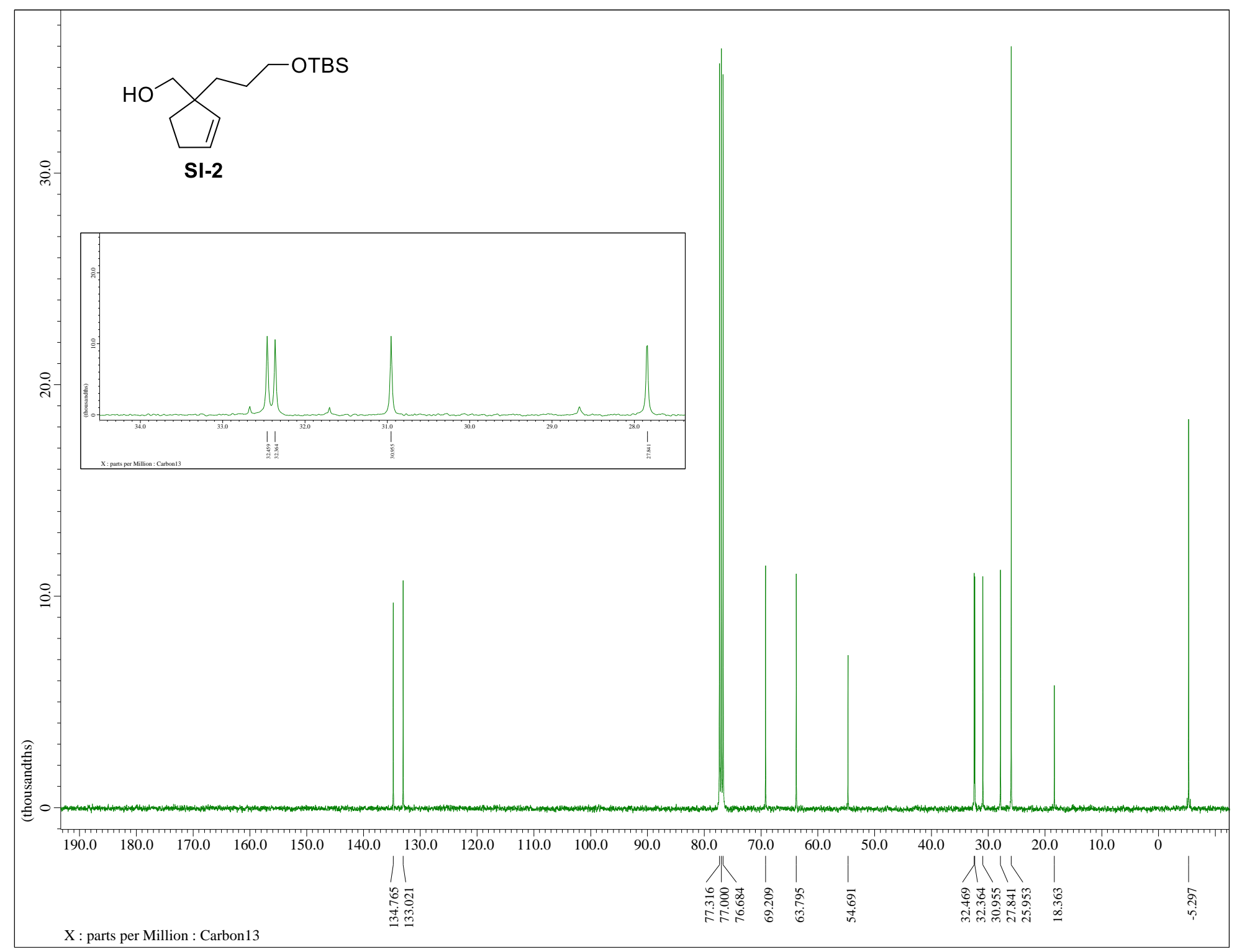

${ }^{13} \mathrm{C} \mathrm{NMR}, 100 \mathrm{MHz}, \mathrm{CDCl}_{3}$ 


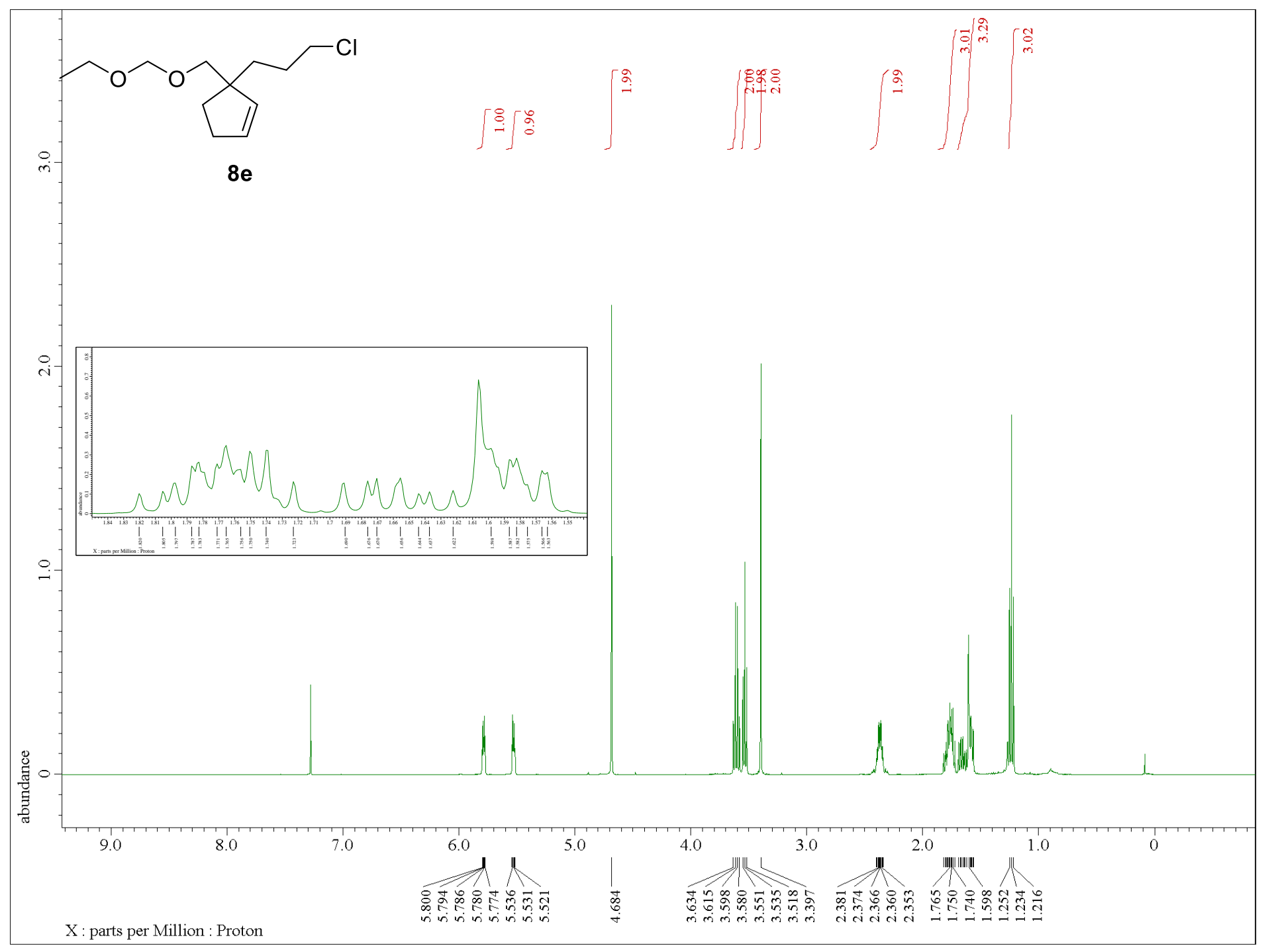

${ }^{1} \mathrm{H} \mathrm{NMR}, 400 \mathrm{MHz}, \mathrm{CDCl}_{3}$ 


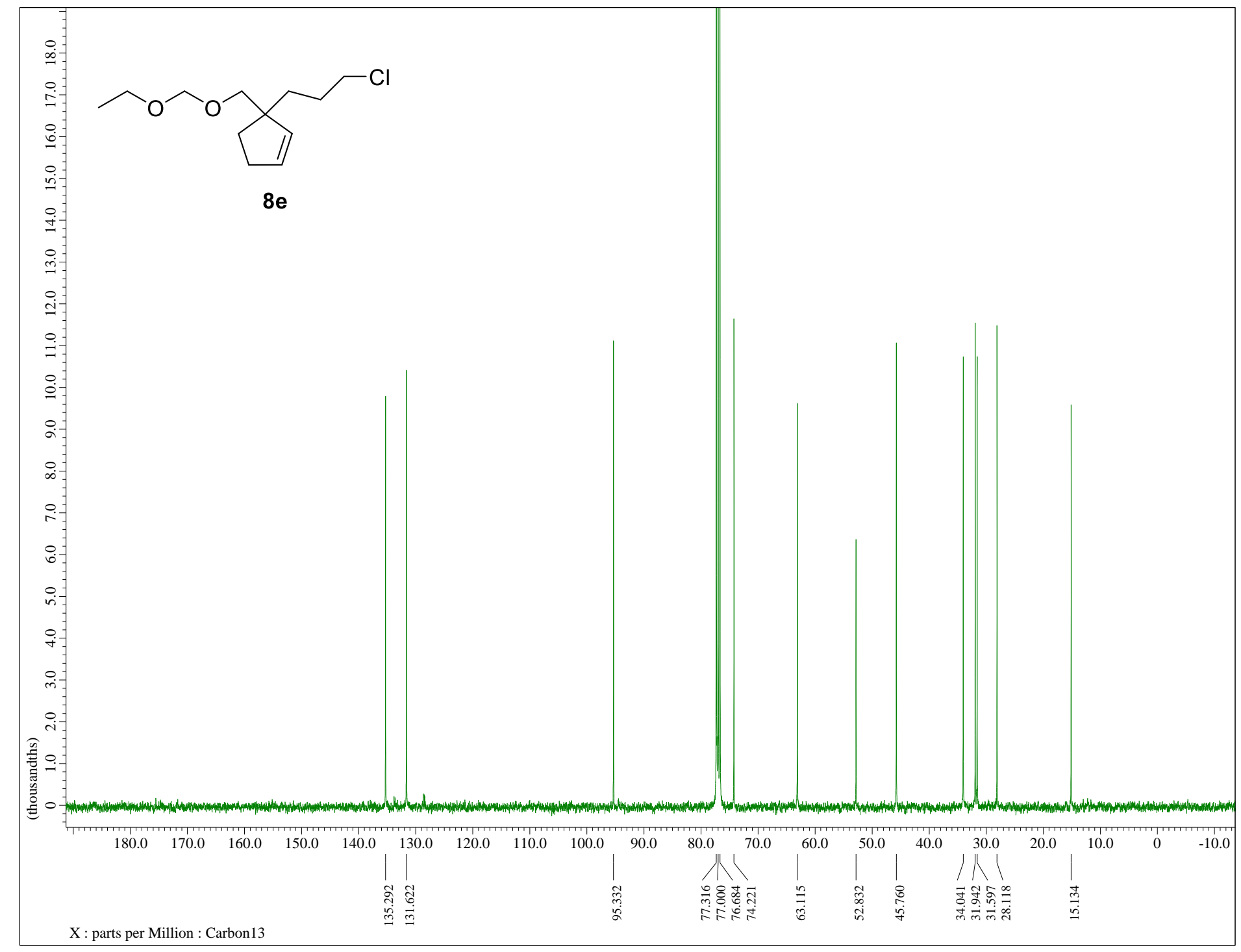

${ }^{13} \mathrm{C} \mathrm{NMR}, 100 \mathrm{MHz}, \mathrm{CDCl}_{3}$ 


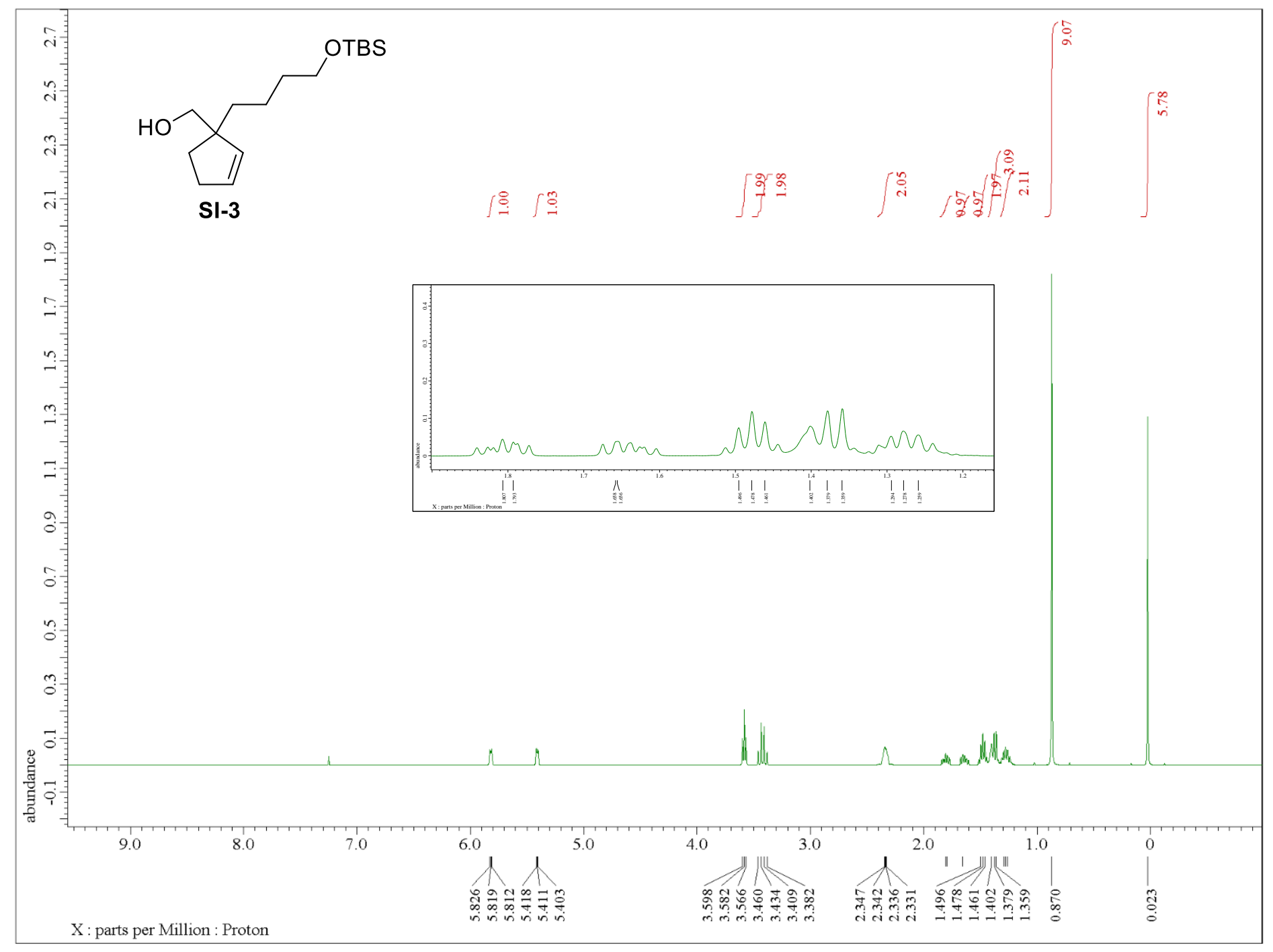

${ }^{1} \mathrm{H} \mathrm{NMR}, 400 \mathrm{MHz}, \mathrm{CDCl}_{3}$ 


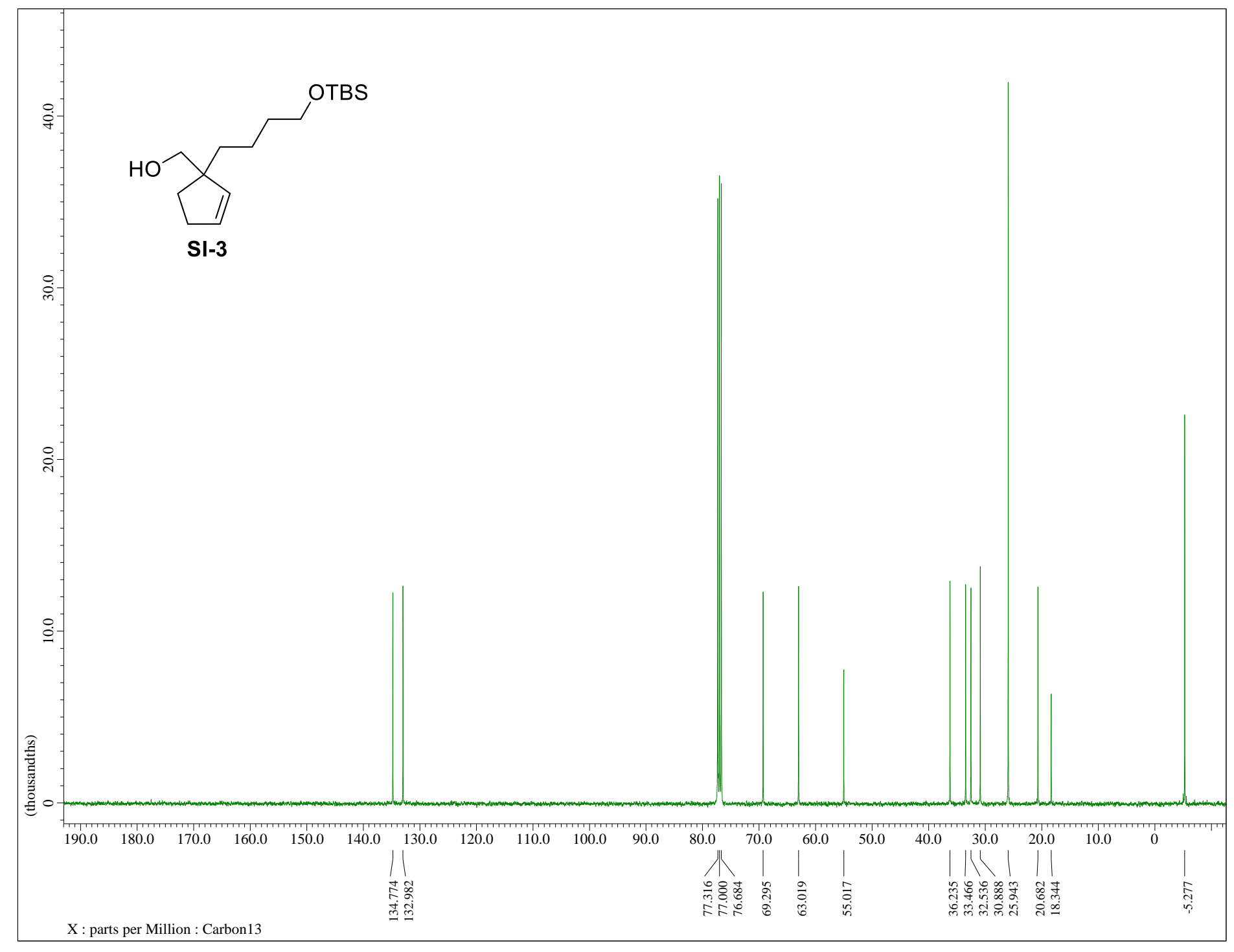

${ }^{13} \mathrm{C} \mathrm{NMR}, 100 \mathrm{MHz}, \mathrm{CDCl}_{3}$ 


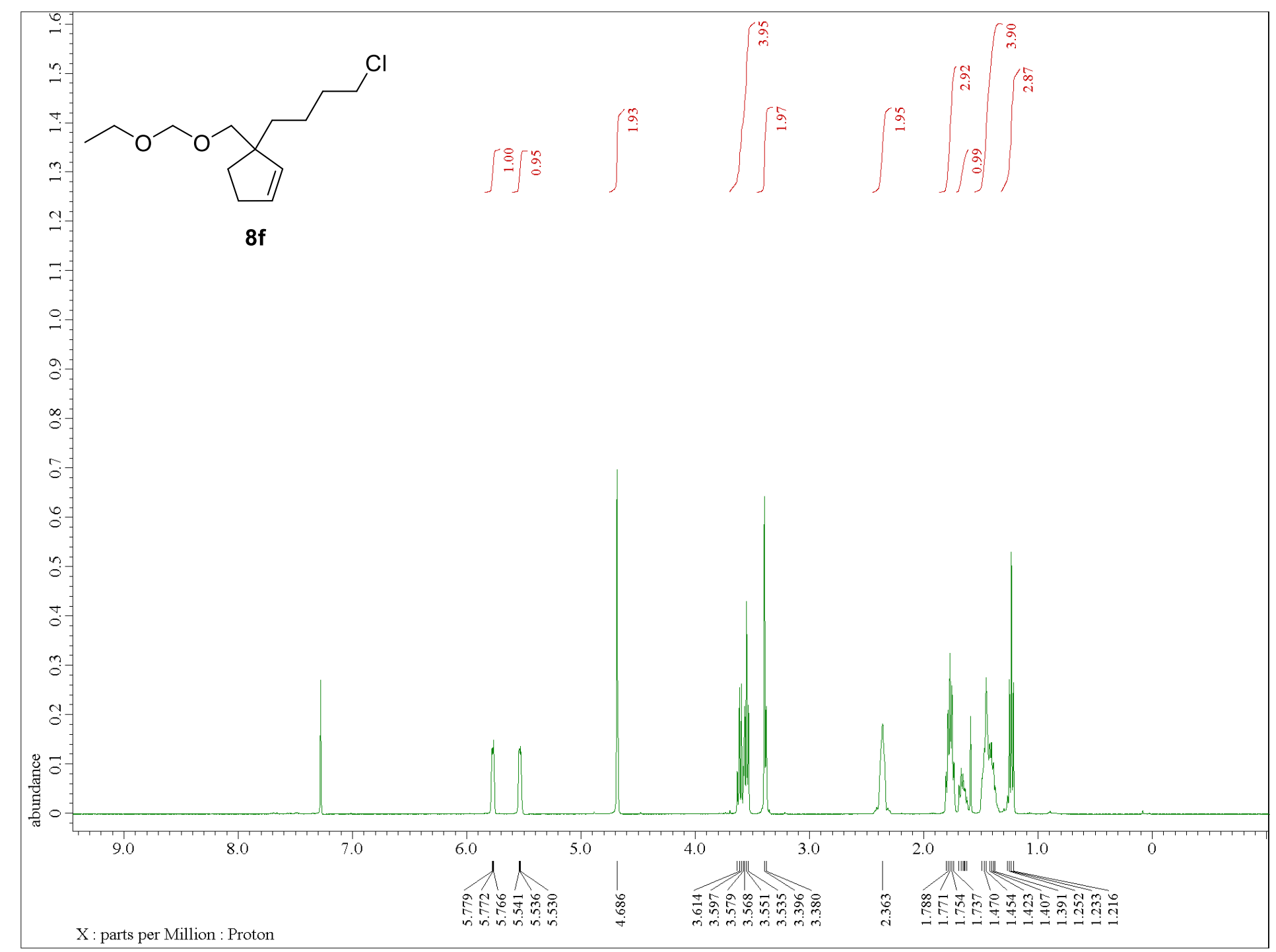

${ }^{1} \mathrm{H} \mathrm{NMR}, 400 \mathrm{MHz}, \mathrm{CDCl}_{3}$ 


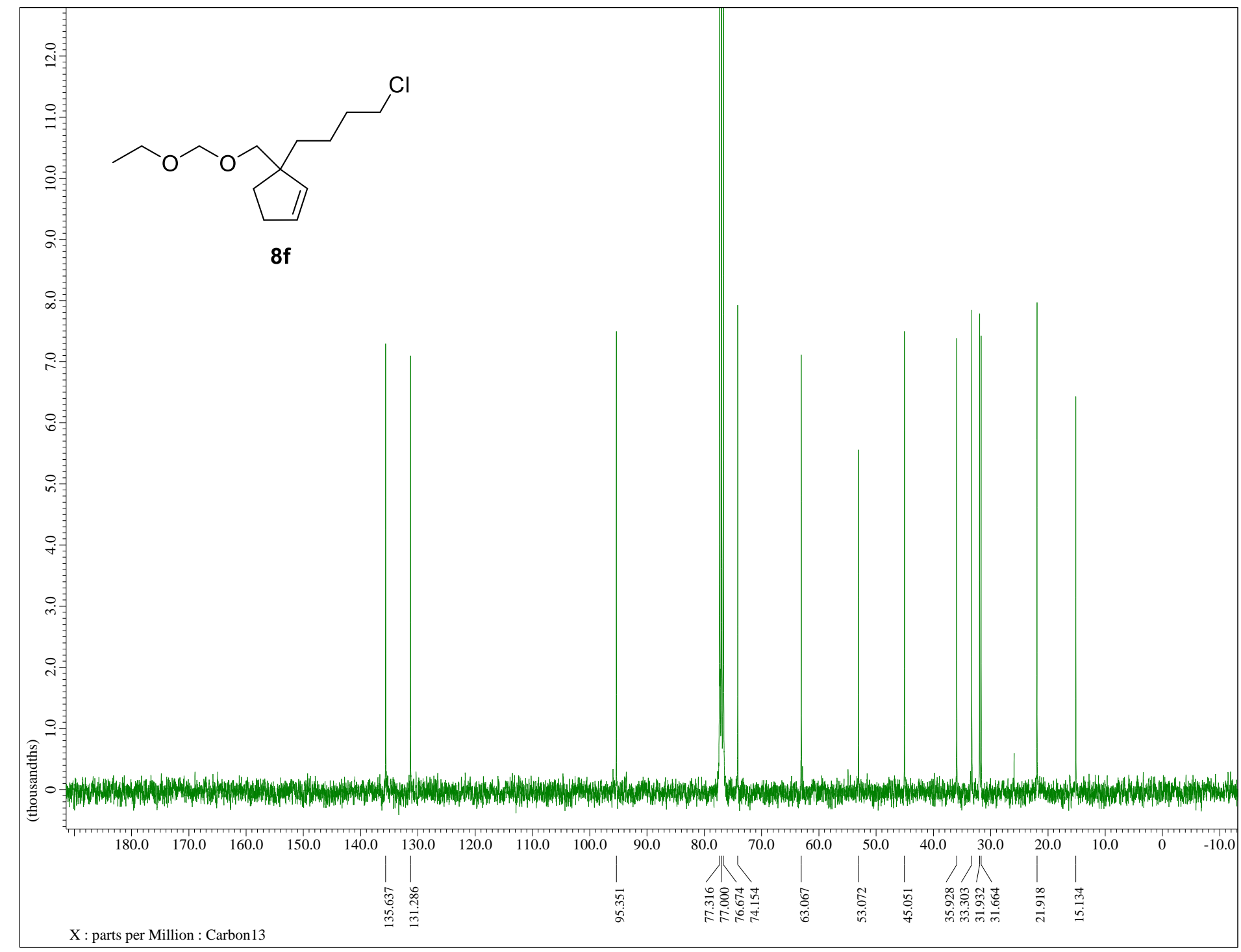

${ }^{13} \mathrm{C} \mathrm{NMR}, 100 \mathrm{MHz}, \mathrm{CDCl}_{3}$ 


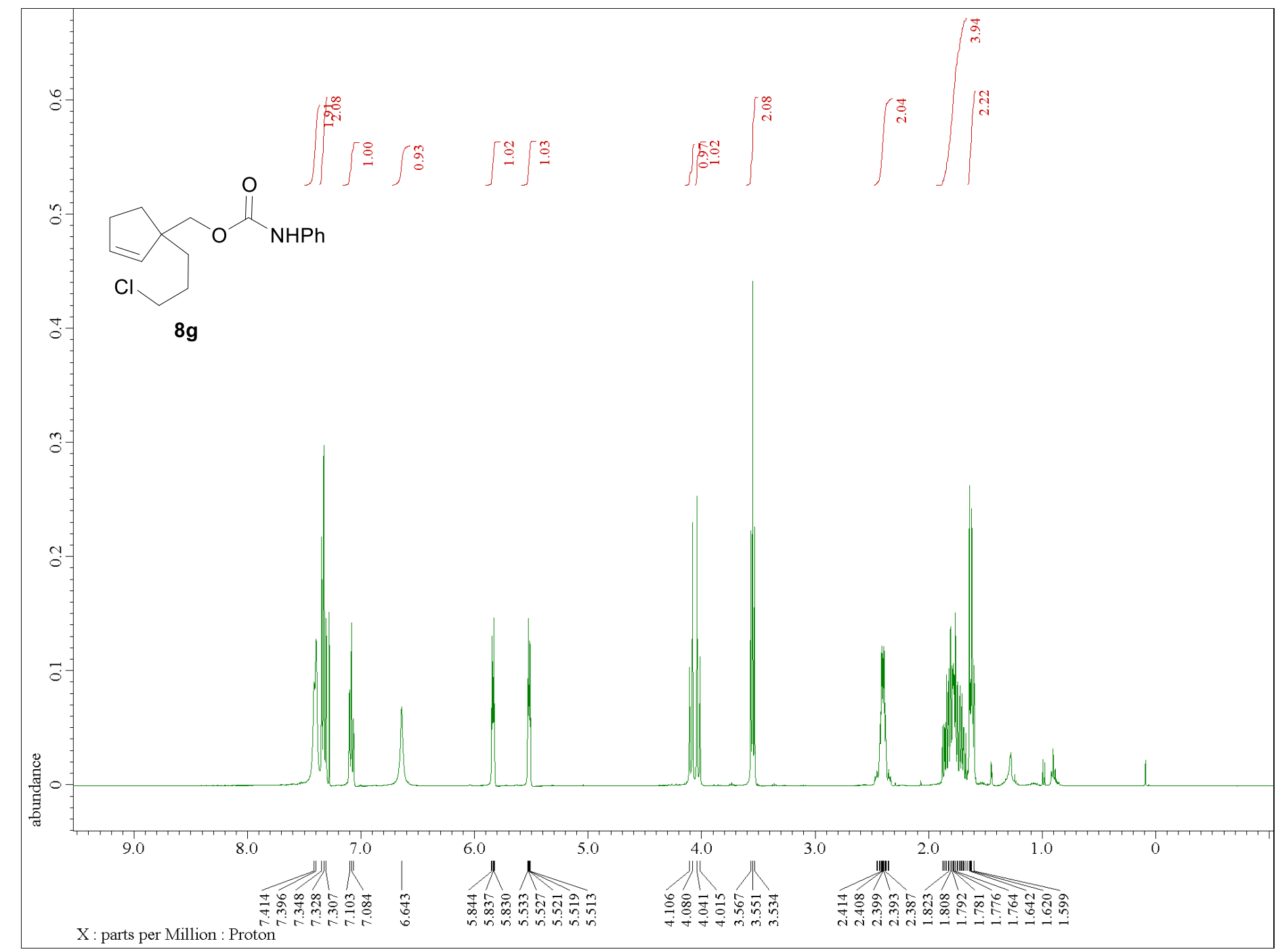

${ }^{1} \mathrm{H} \mathrm{NMR}, 400 \mathrm{MHz}, \mathrm{CDCl}_{3}$ 


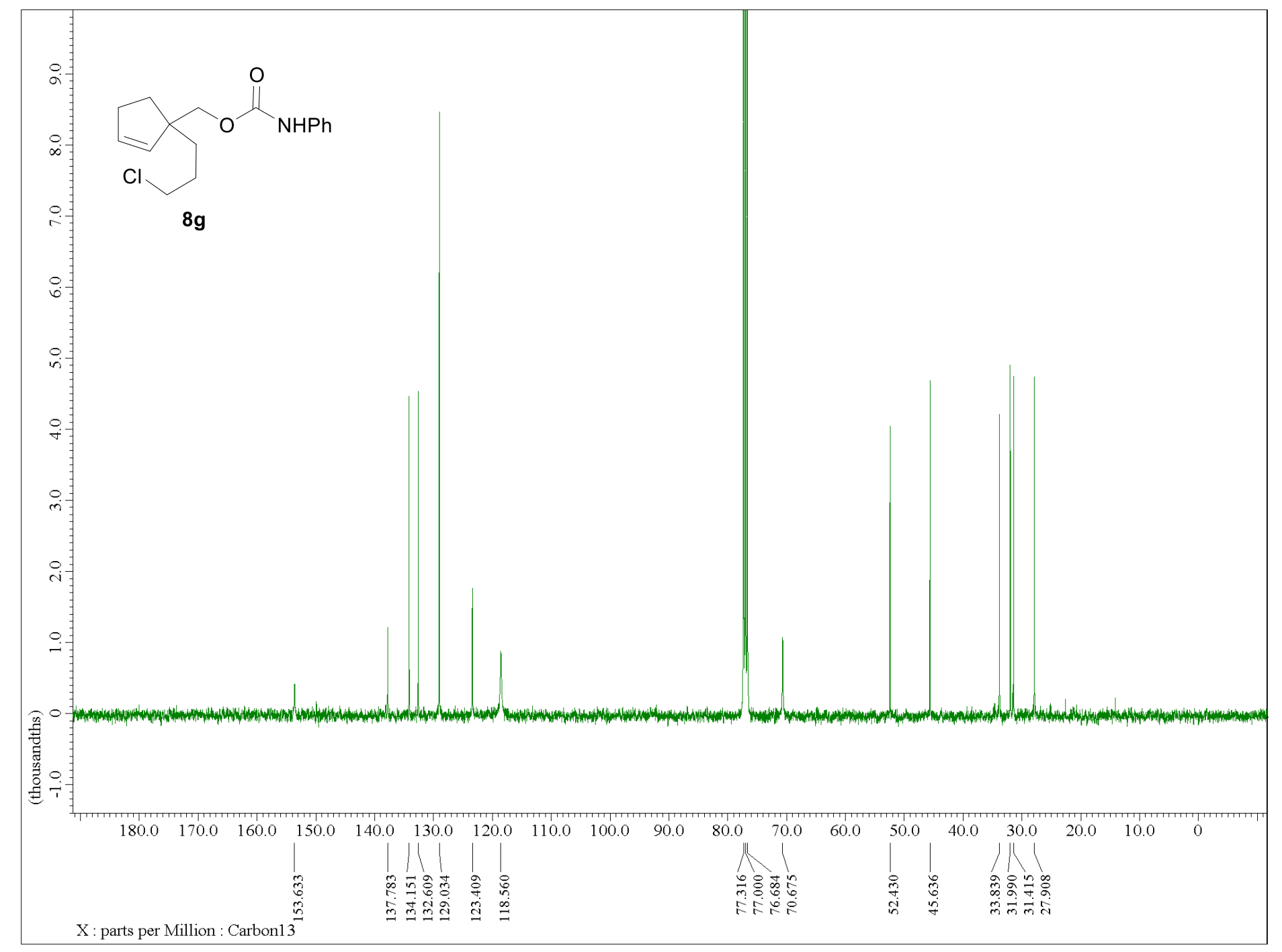

${ }^{13} \mathrm{C} \mathrm{NMR}, 100 \mathrm{MHz}, \mathrm{CDCl}_{3}$ 


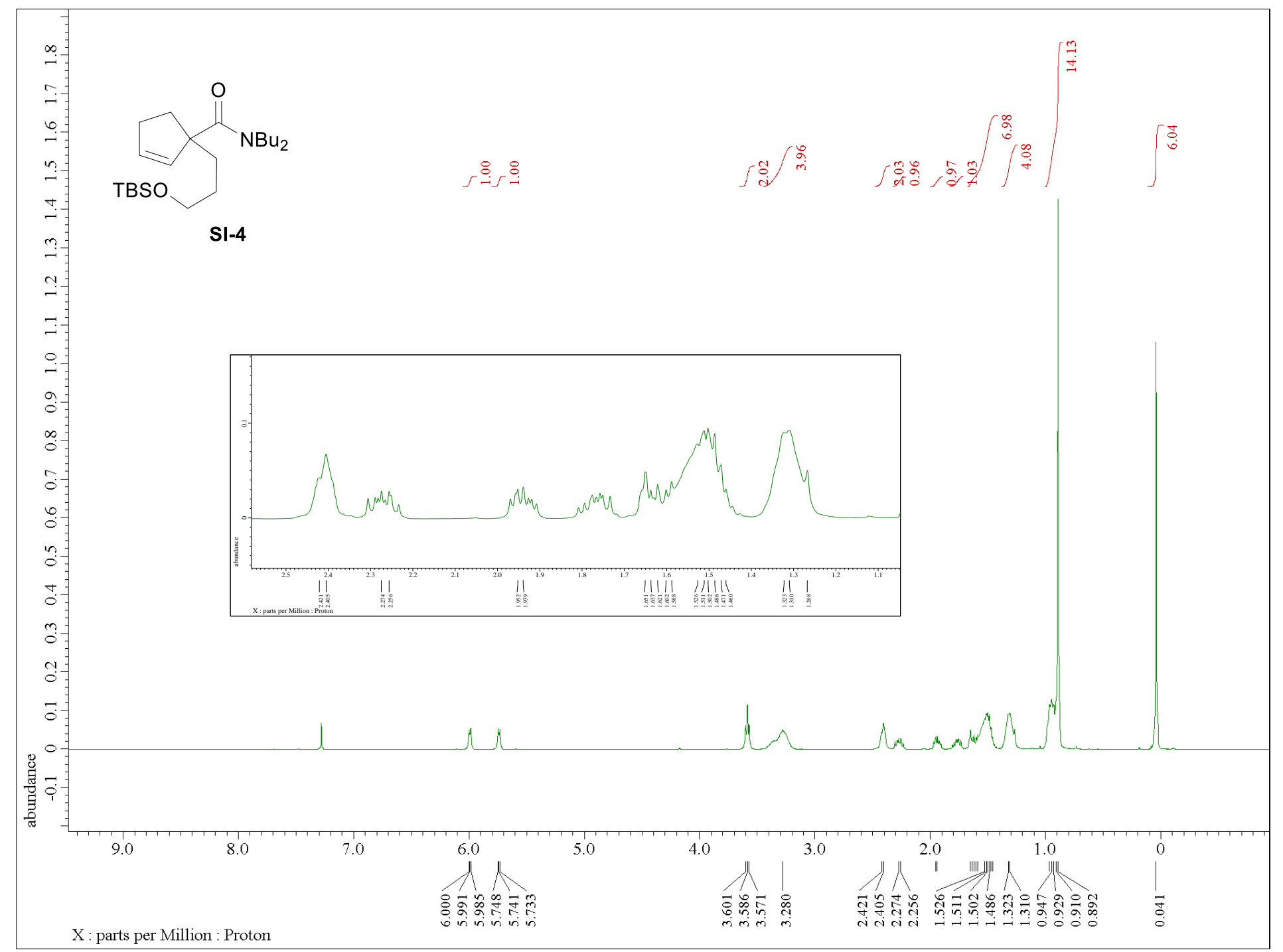

${ }^{1} \mathrm{H} \mathrm{NMR}, 400 \mathrm{MHz}, \mathrm{CDCl}_{3}$ 


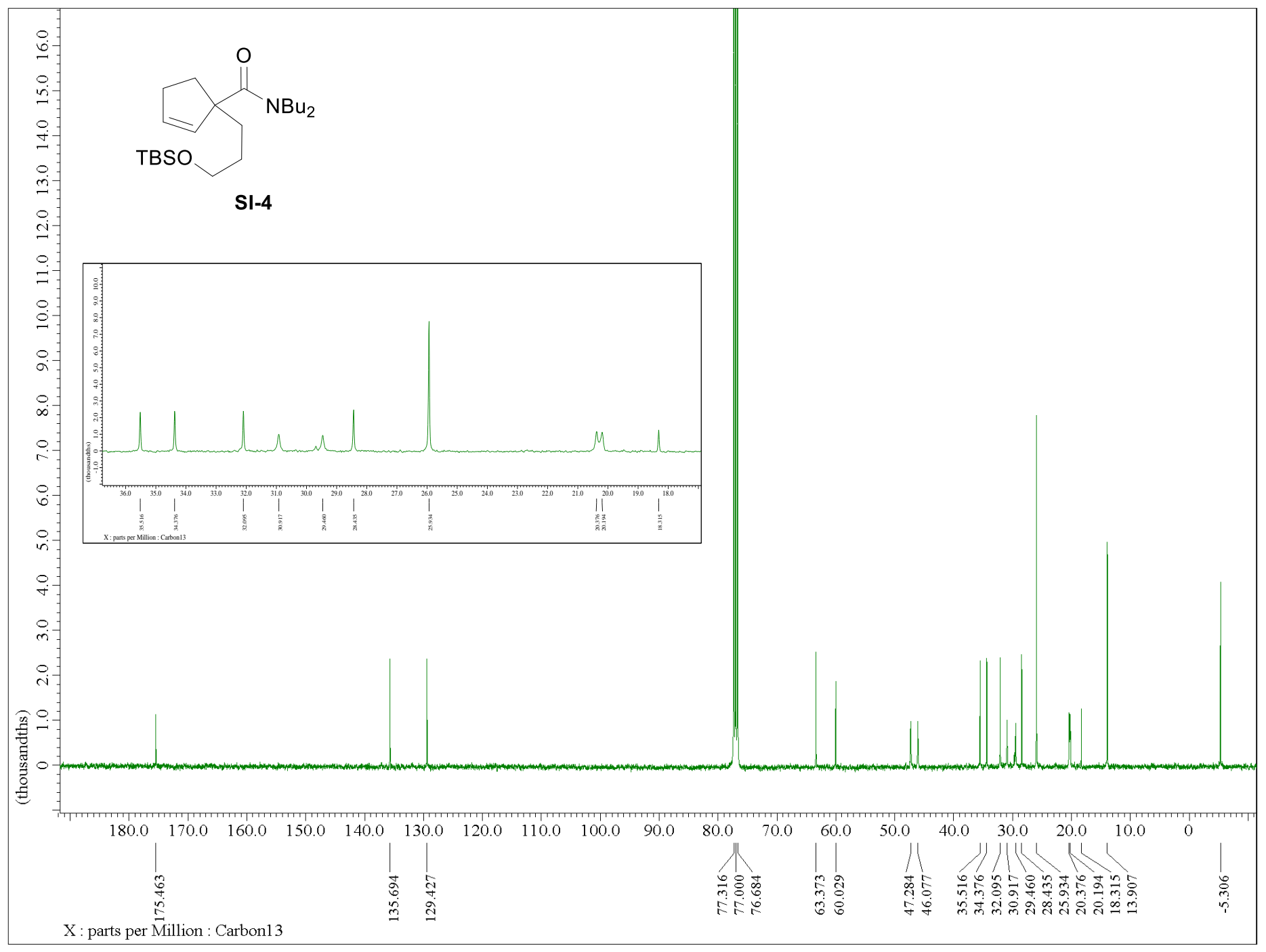

${ }^{13} \mathrm{C} \mathrm{NMR}, 100 \mathrm{MHz}, \mathrm{CDCl}_{3}$ 


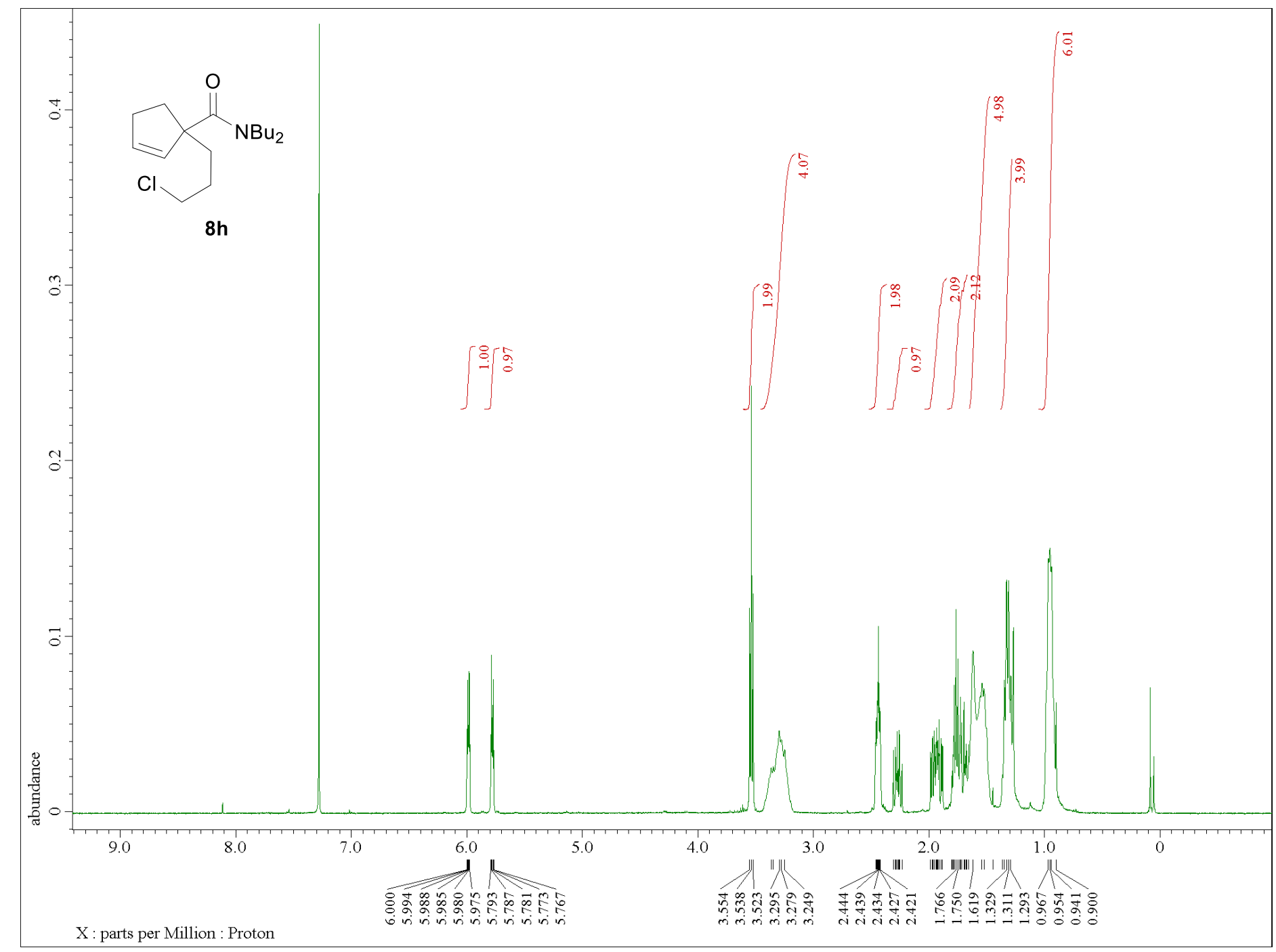

${ }^{1} \mathrm{H} \mathrm{NMR}, 400 \mathrm{MHz}, \mathrm{CDCl}_{3}$ 


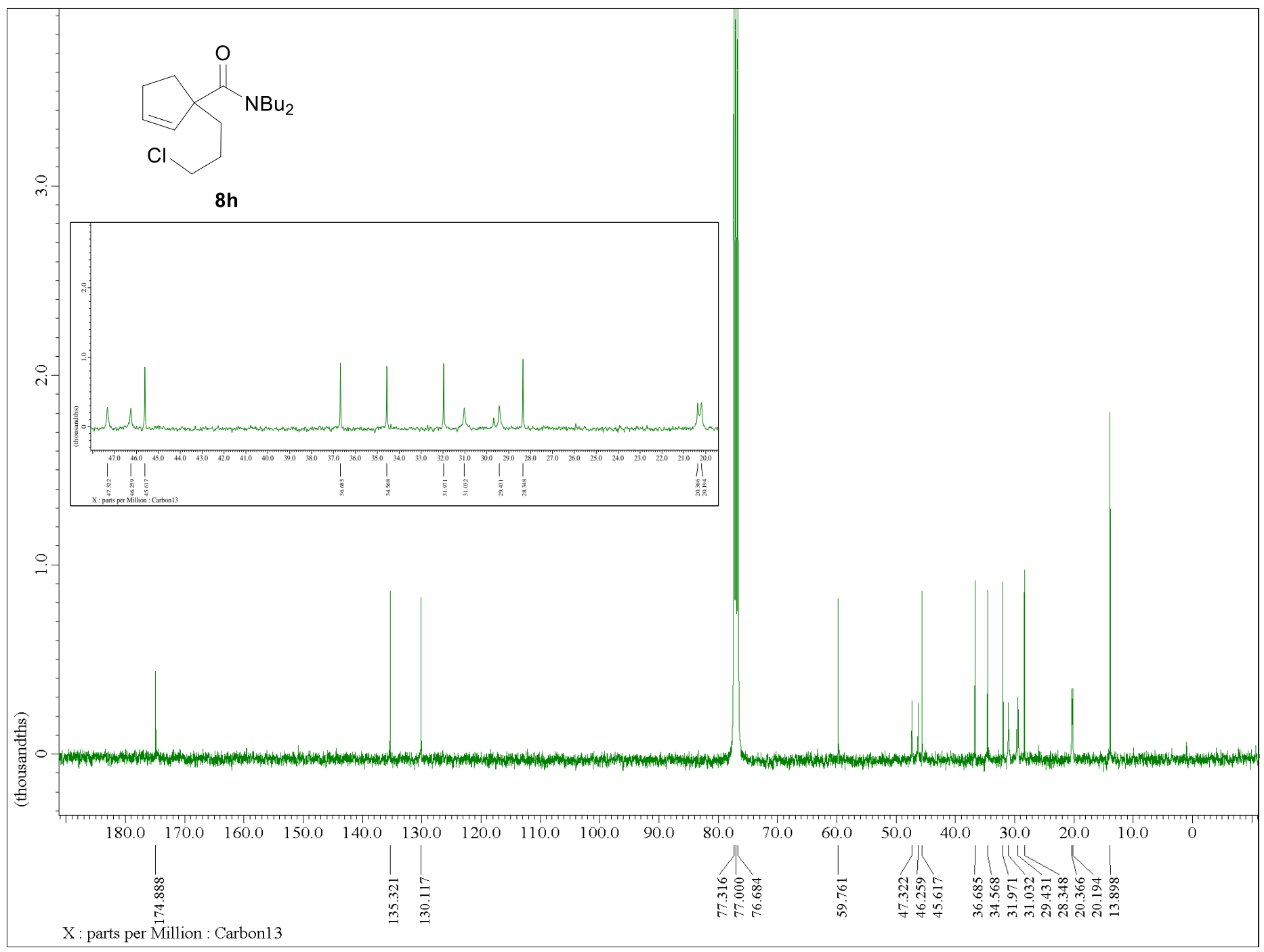

${ }^{13} \mathrm{C} \mathrm{NMR}, 100 \mathrm{MHz}, \mathrm{CDCl}_{3}$ 


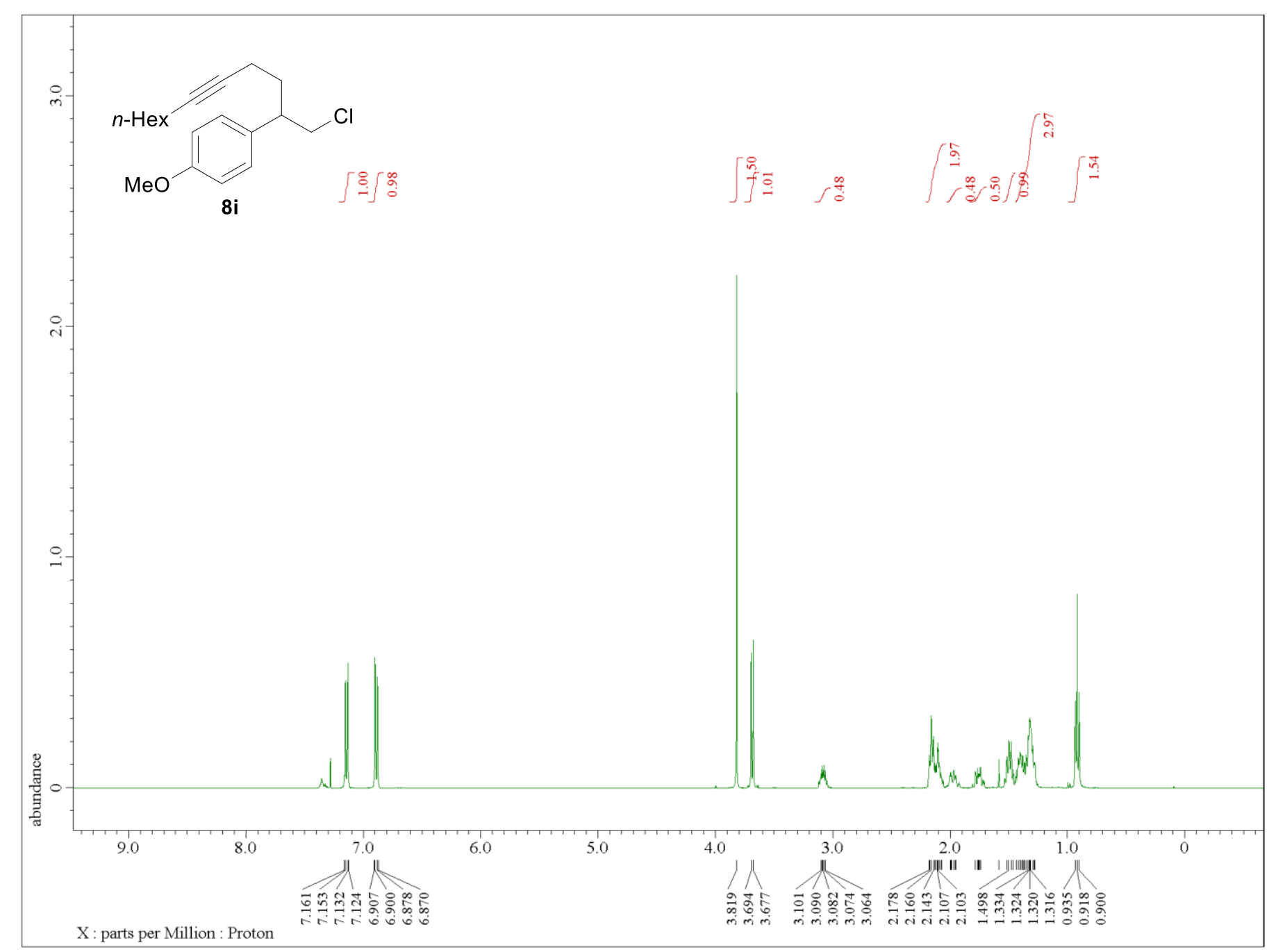

${ }^{1} \mathrm{H} \mathrm{NMR}, 400 \mathrm{MHz}, \mathrm{CDCl}_{3}$ 


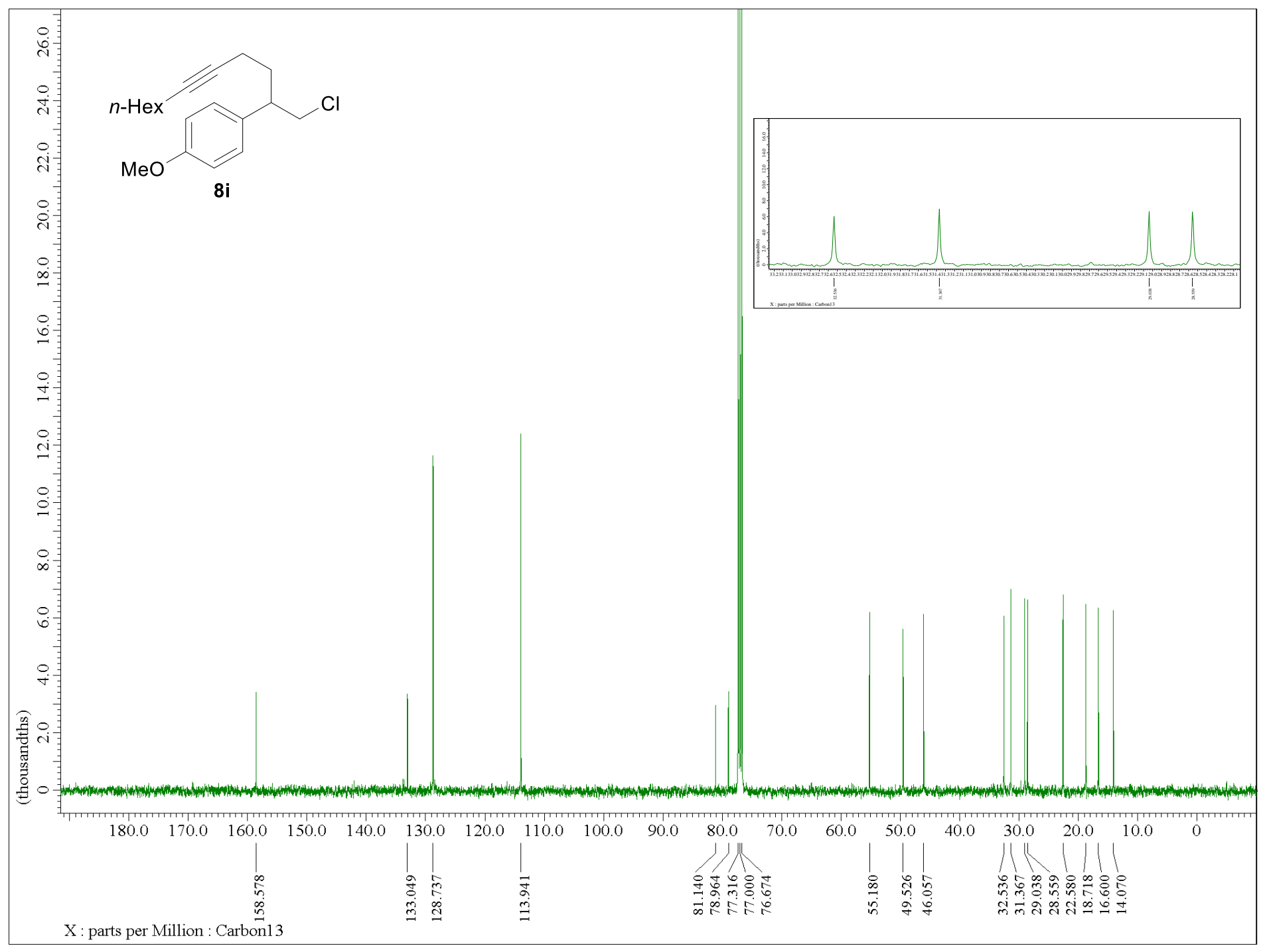

${ }^{13} \mathrm{C} \mathrm{NMR}, 100 \mathrm{MHz}, \mathrm{CDCl}_{3}$ 


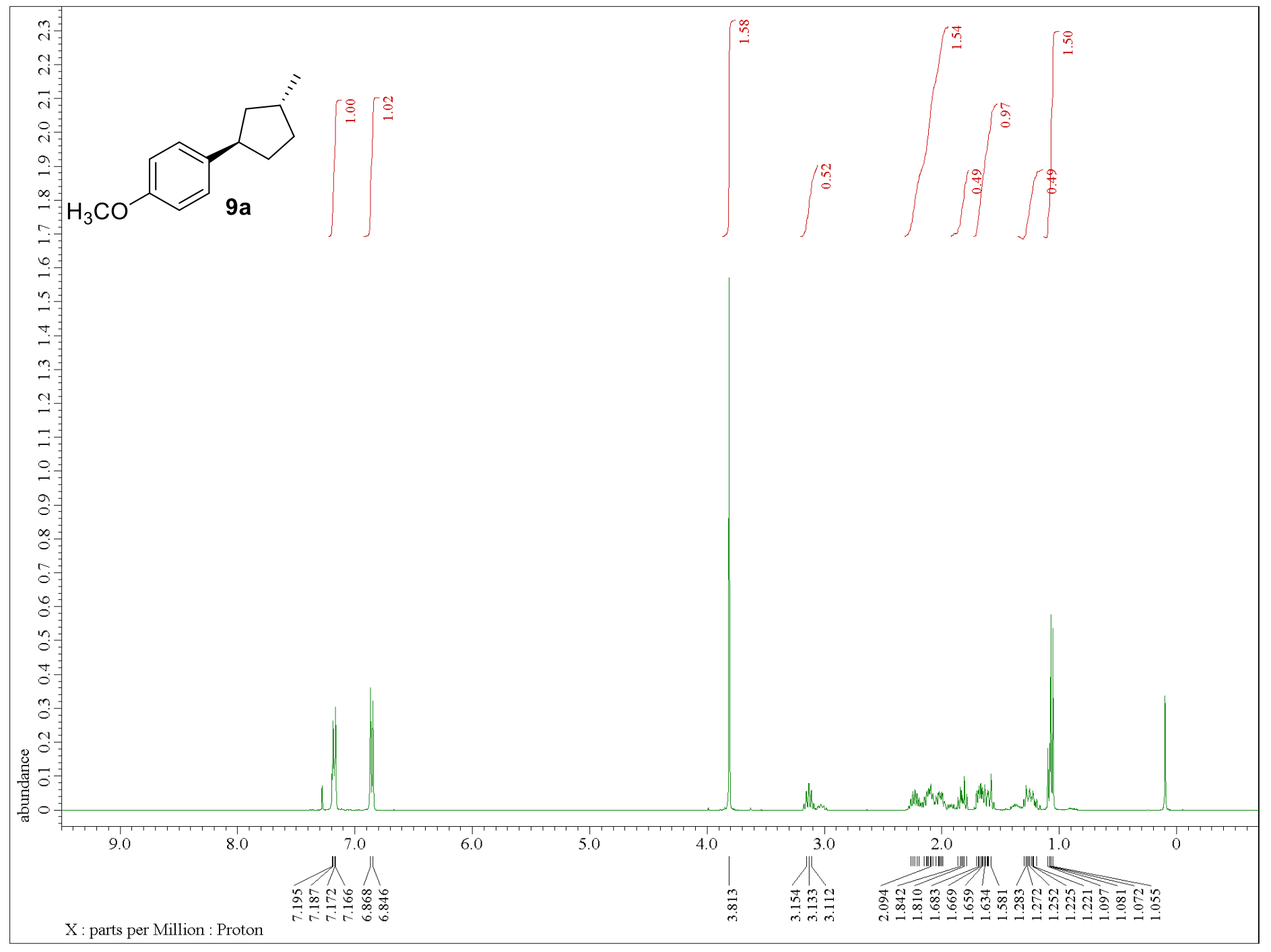

${ }^{1} \mathrm{H} \mathrm{NMR}, 400 \mathrm{MHz}, \mathrm{CDCl}_{3}$ 


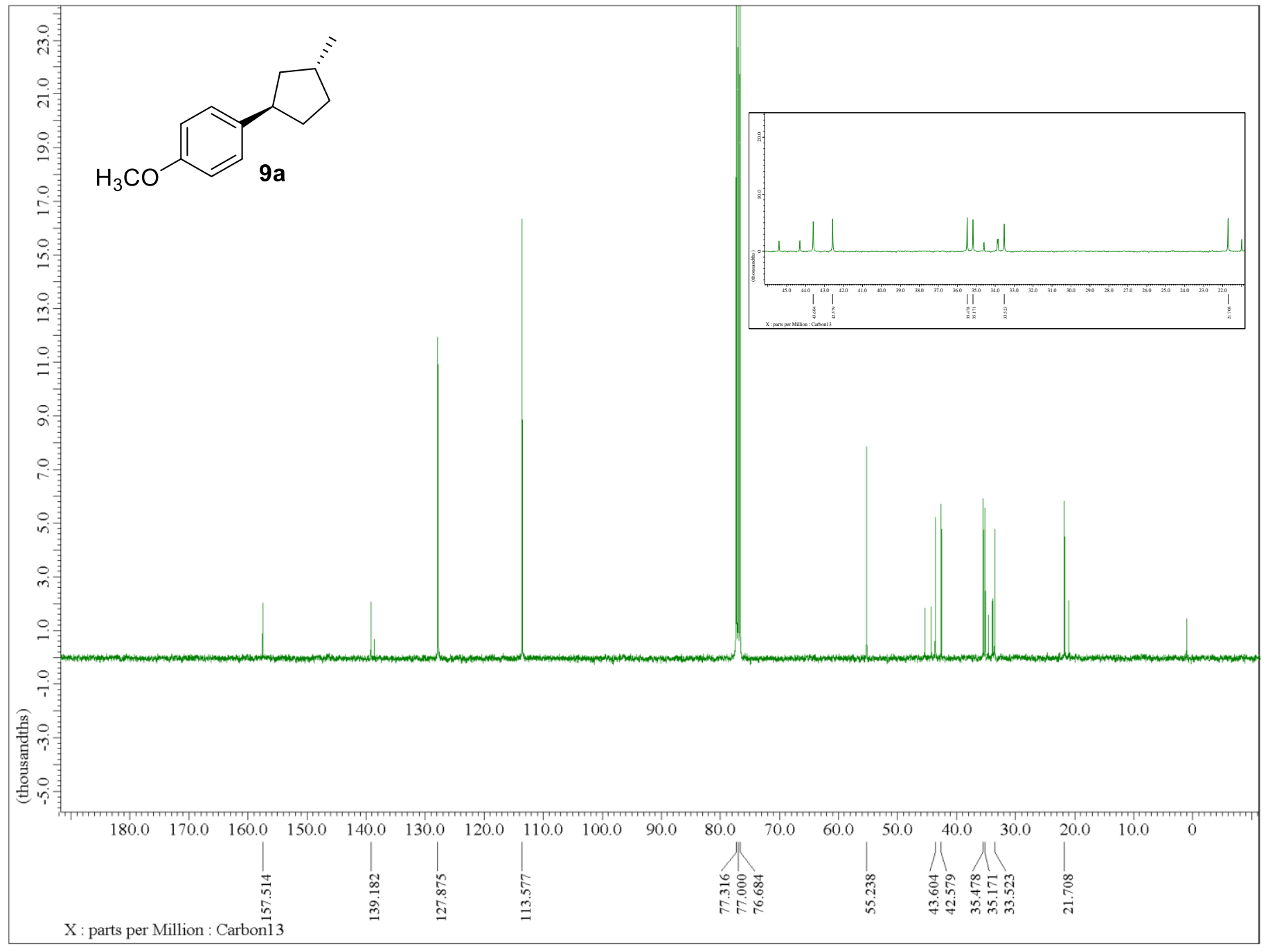

${ }^{13} \mathrm{C} \mathrm{NMR}, 100 \mathrm{MHz}, \mathrm{CDCl}_{3}$ 


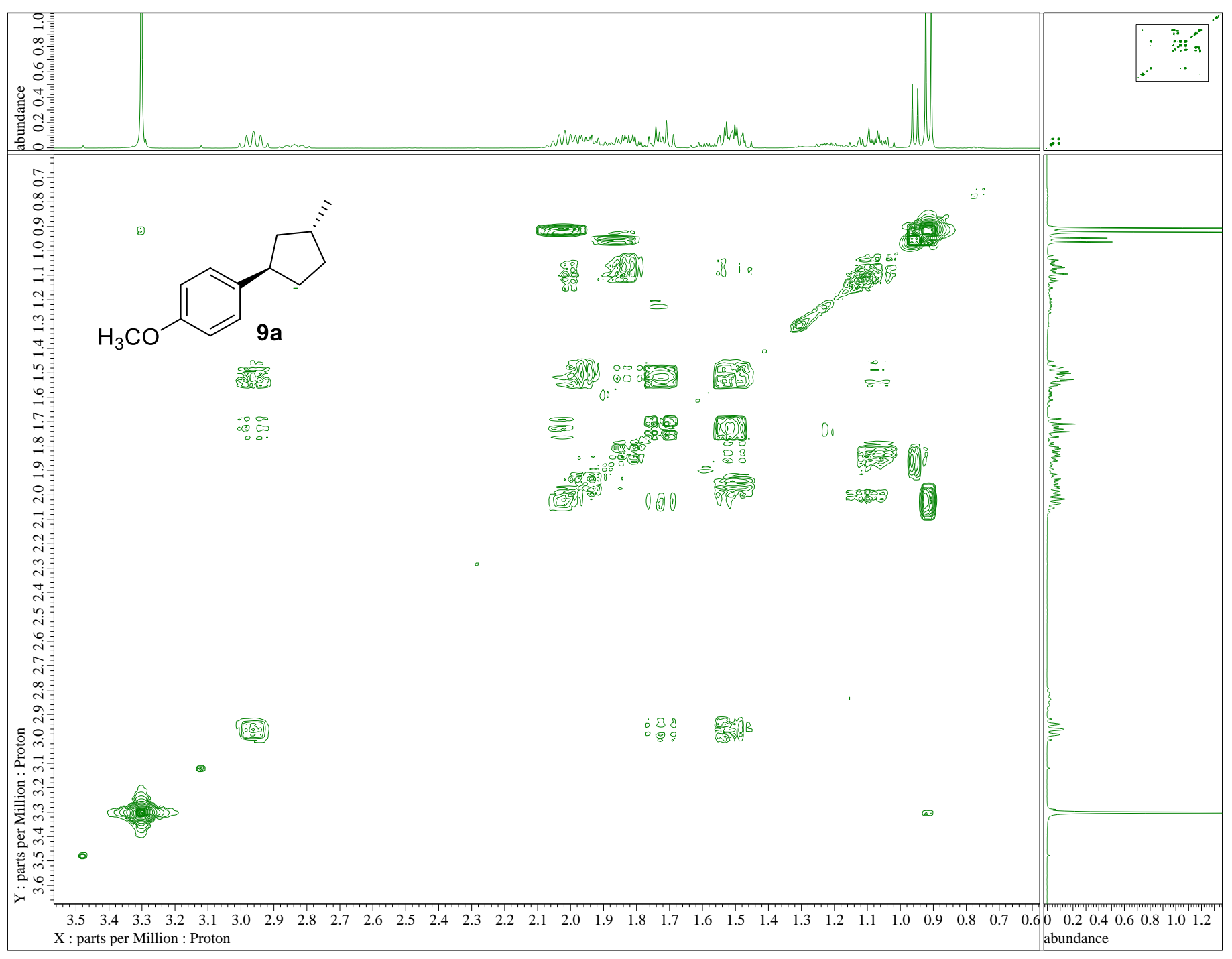

$\operatorname{COSY}\left({ }^{1} \mathrm{H}-{ }^{1} \mathrm{H}\right), \mathrm{CDCl}_{3}$ 


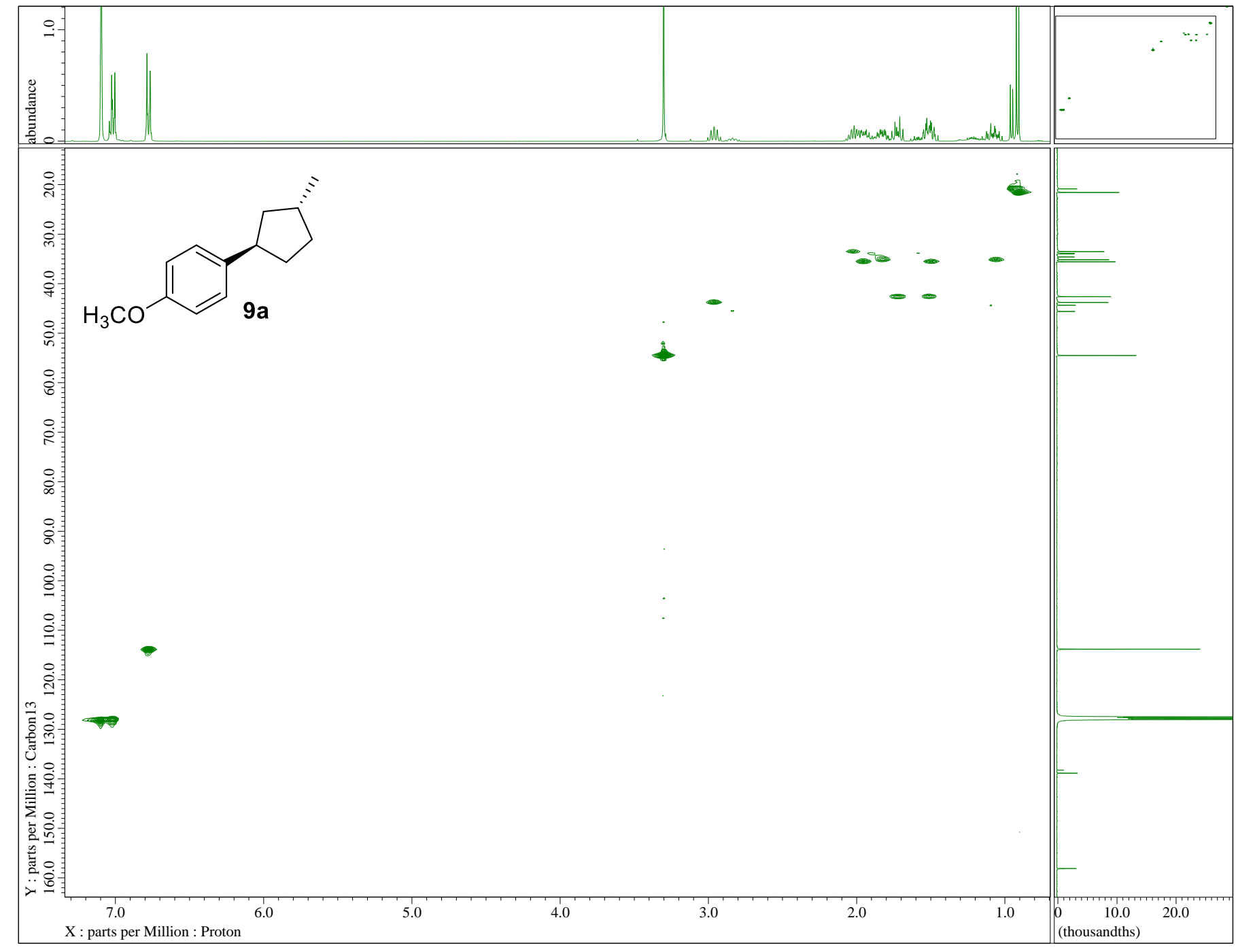

$\mathrm{HSQC}\left({ }^{1} \mathrm{H}-{ }^{13} \mathrm{C}\right), \mathrm{CDCl}_{3}$ 


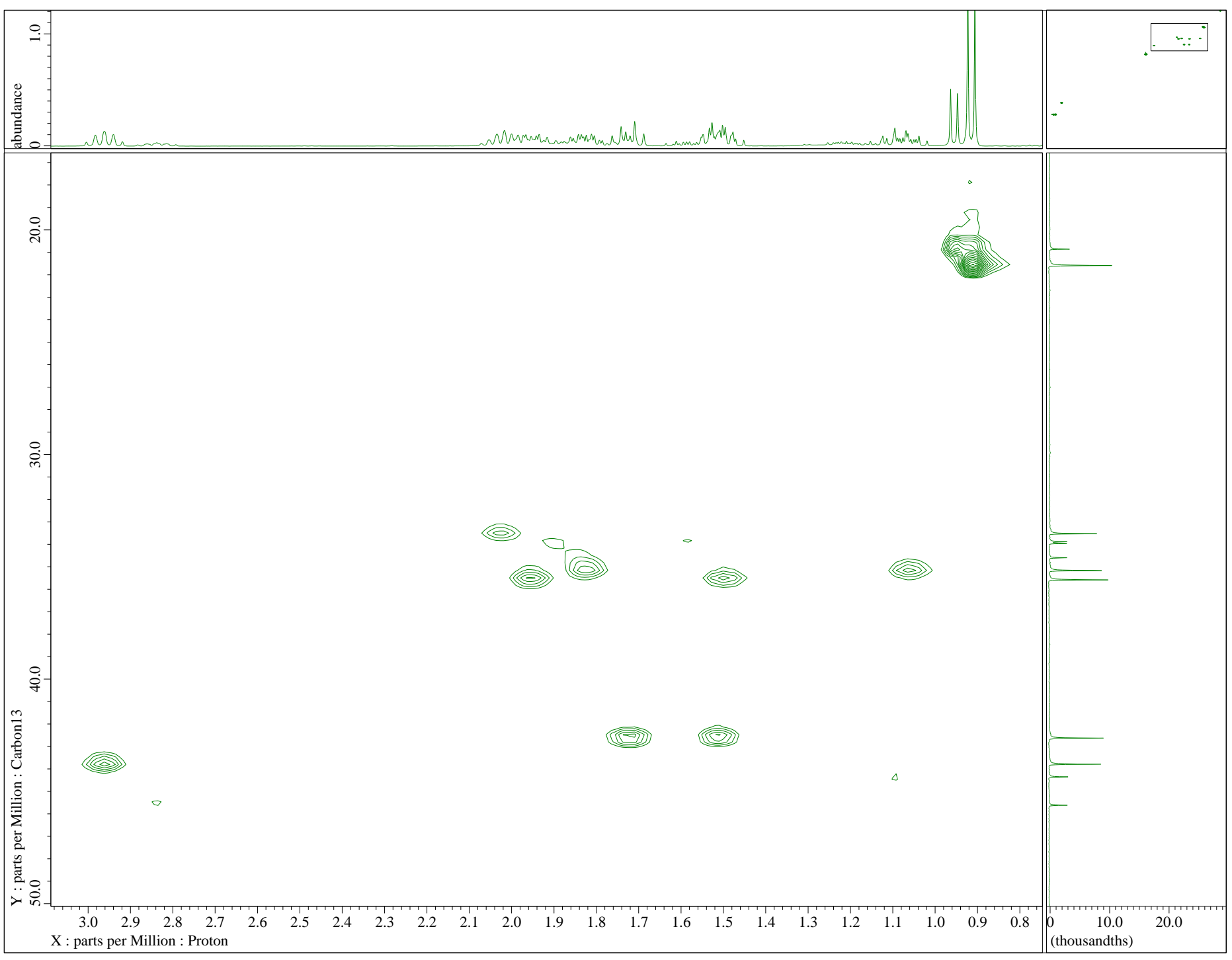

HSQC $\left({ }^{1} \mathrm{H}-{ }^{13} \mathrm{C}\right)$ expansion, $\mathrm{CDCl}_{3}$ 


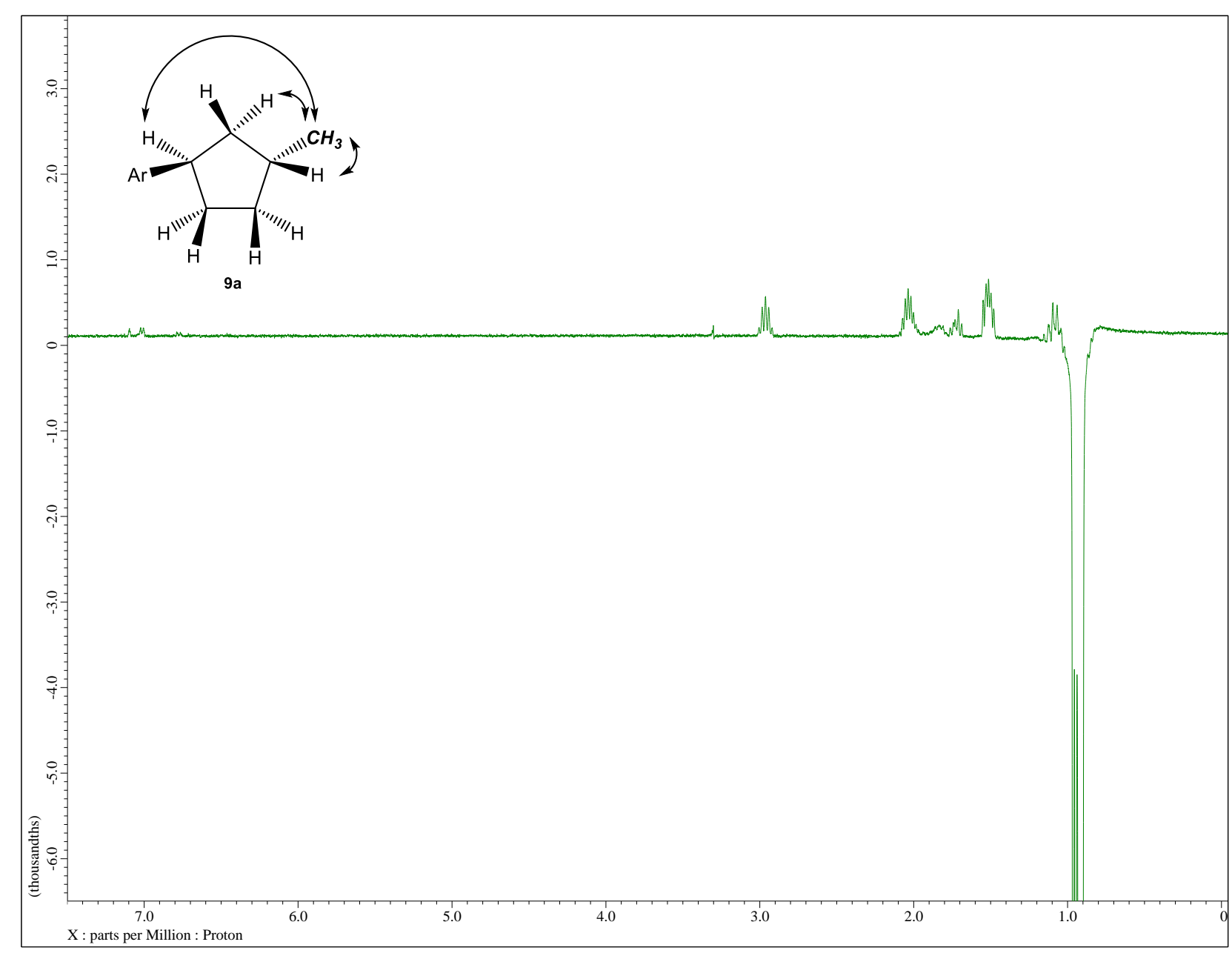

NOE DIFF, $\mathrm{CDCl}_{3}$ 


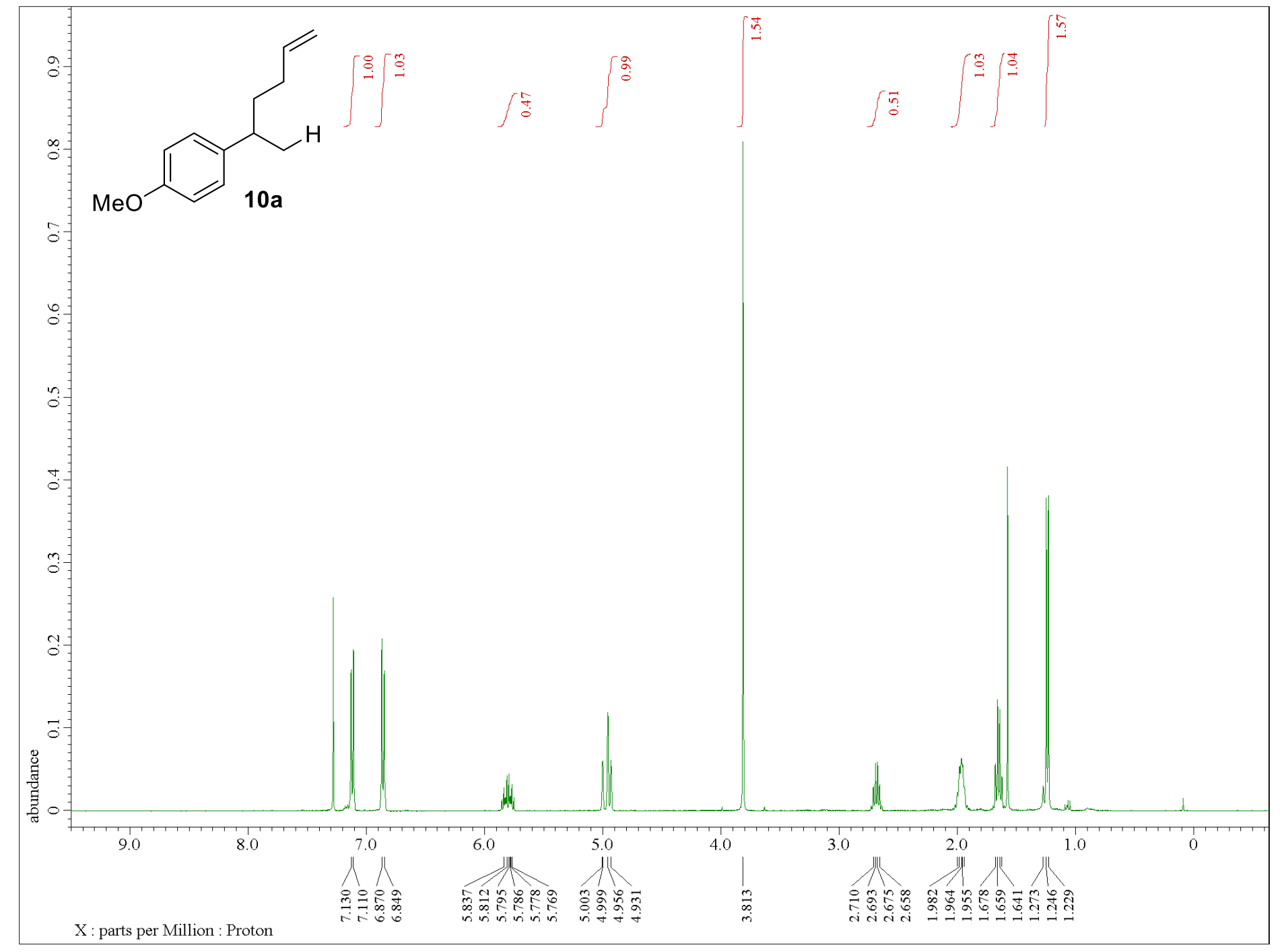

${ }^{1} \mathrm{H} \mathrm{NMR}, 400 \mathrm{MHz}, \mathrm{CDCl}_{3}$ 


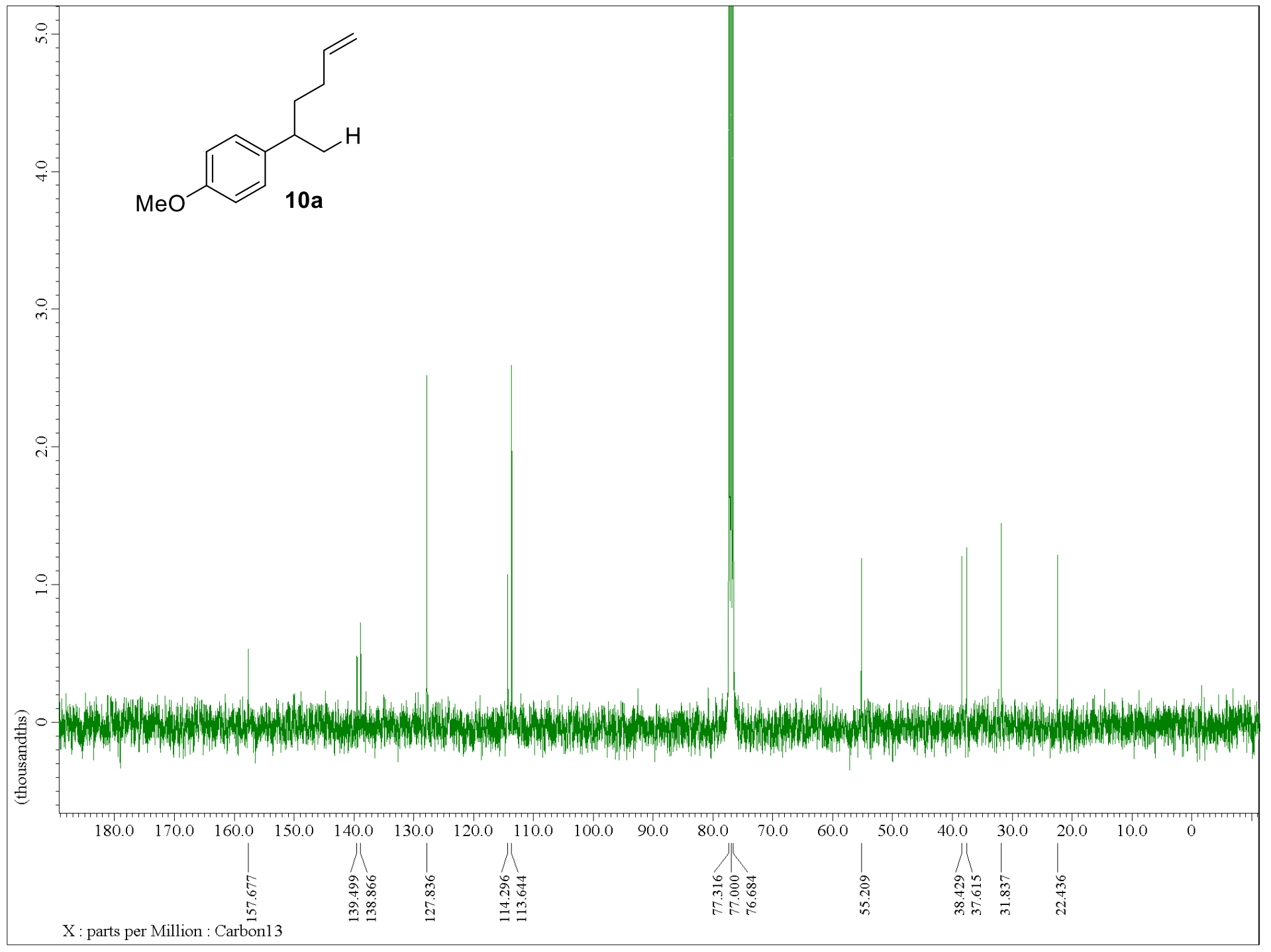

${ }^{13} \mathrm{C} \mathrm{NMR}, 100 \mathrm{MHz}, \mathrm{CDCl}_{3}$ 


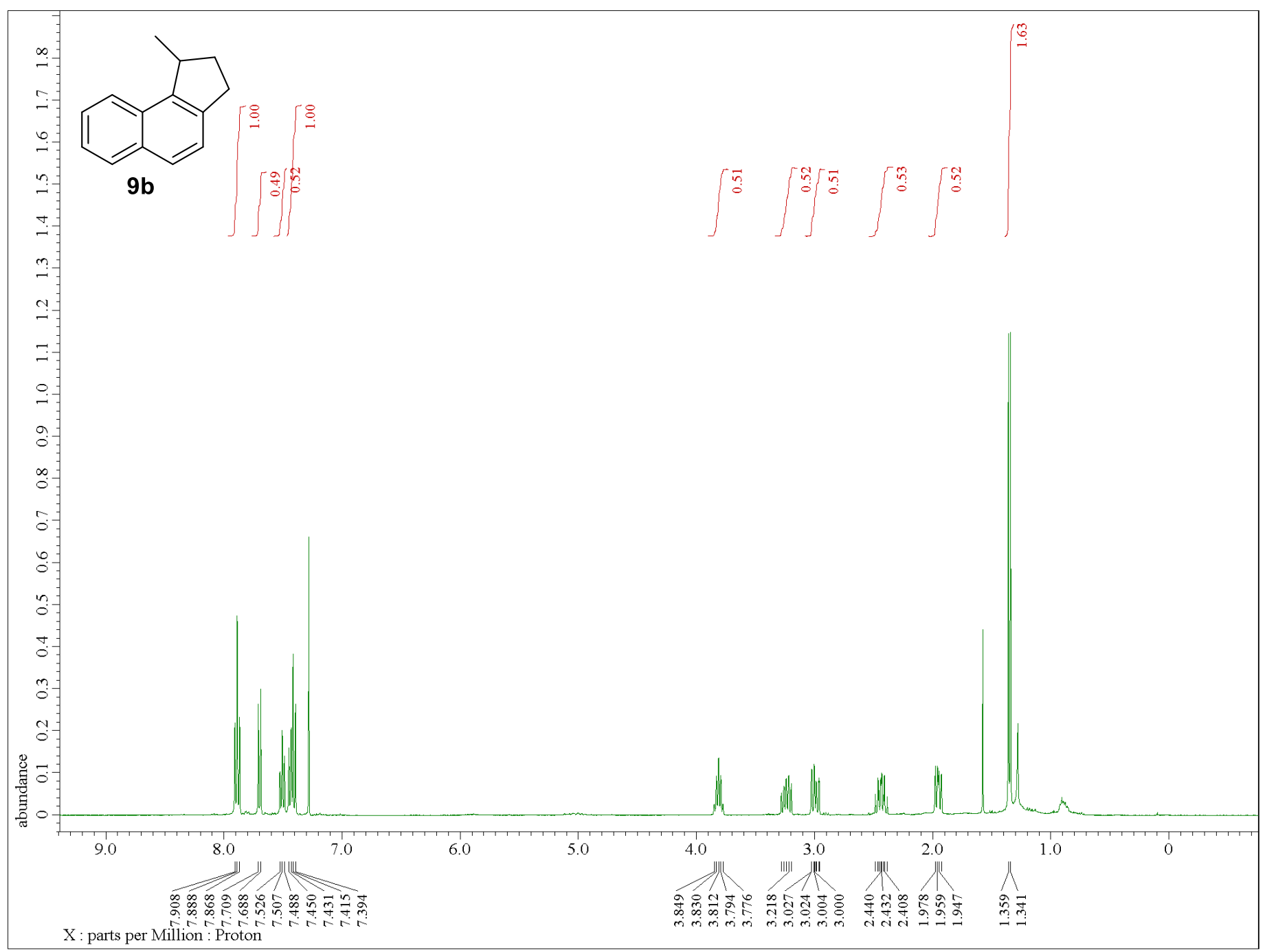

${ }^{1} \mathrm{H}$ NMR, $400 \mathrm{MHz}, \mathrm{CDCl}_{3}$ 


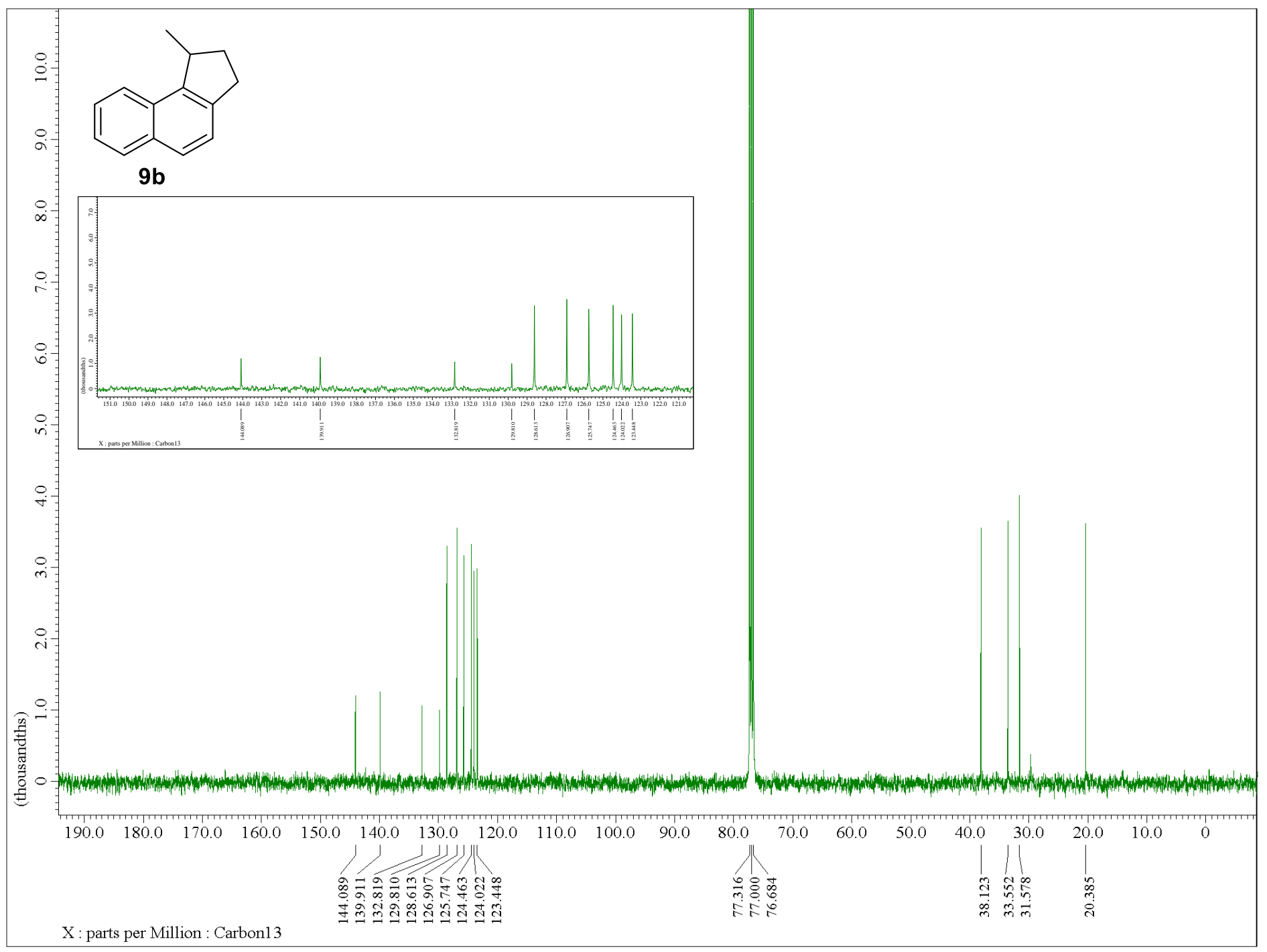

${ }^{13} \mathrm{C} \mathrm{NMR}, 100 \mathrm{MHz}, \mathrm{CDCl}_{3}$ 


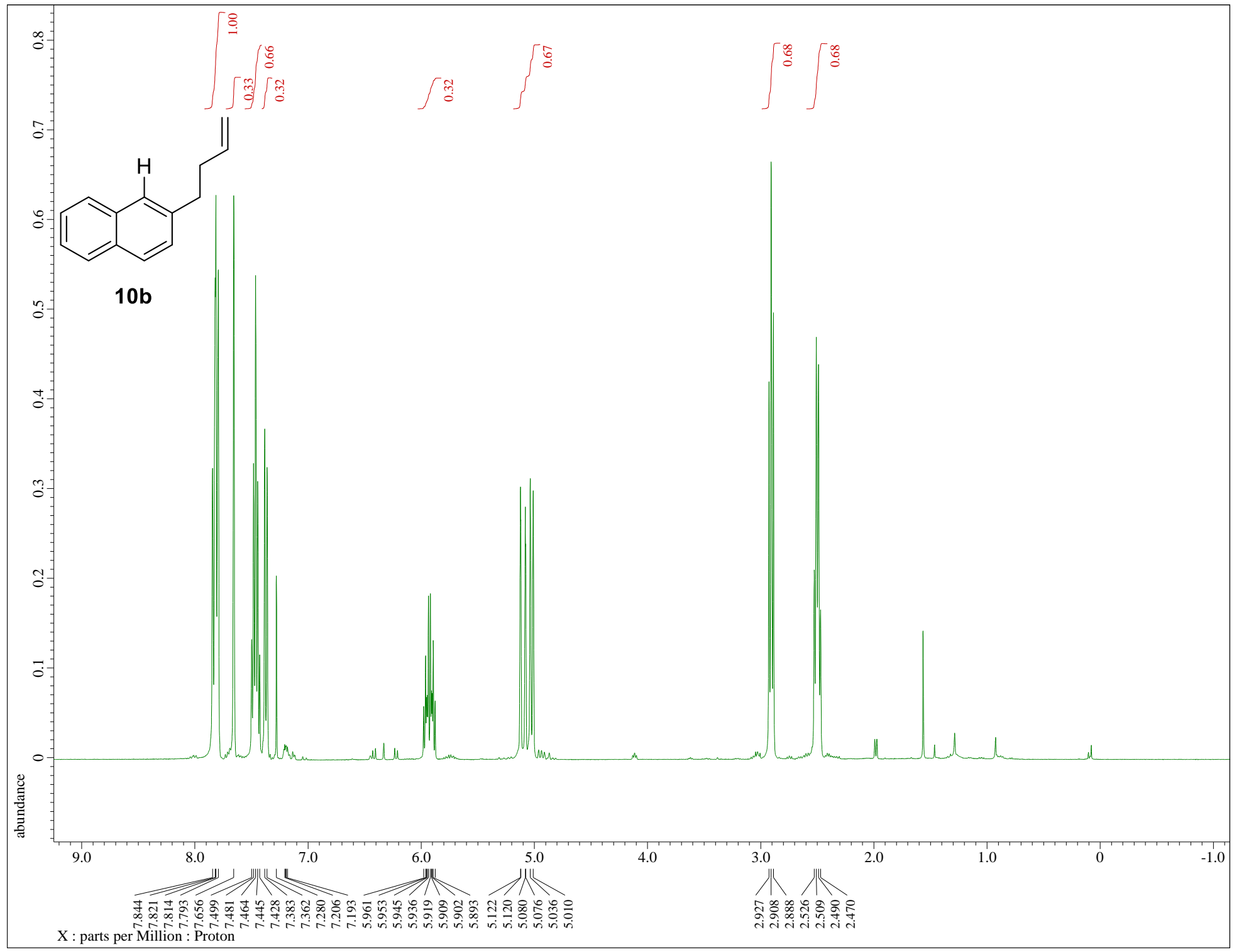

${ }^{1} \mathrm{H} \mathrm{NMR}, 400 \mathrm{MHz}, \mathrm{CDCl}_{3}$ 


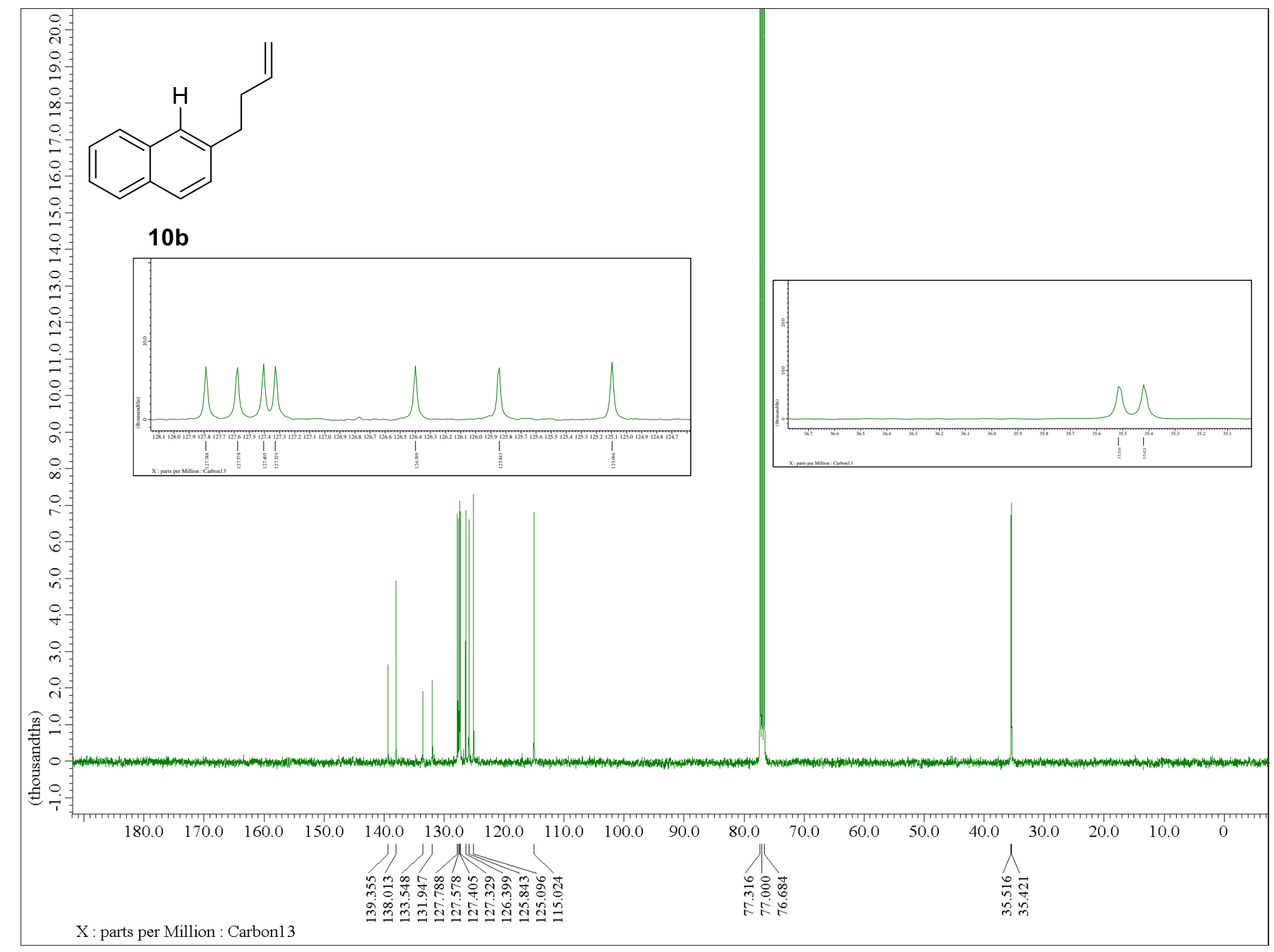

${ }^{13} \mathrm{C}$ NMR, $100 \mathrm{MHz}, \mathrm{CDCl}_{3}$ 


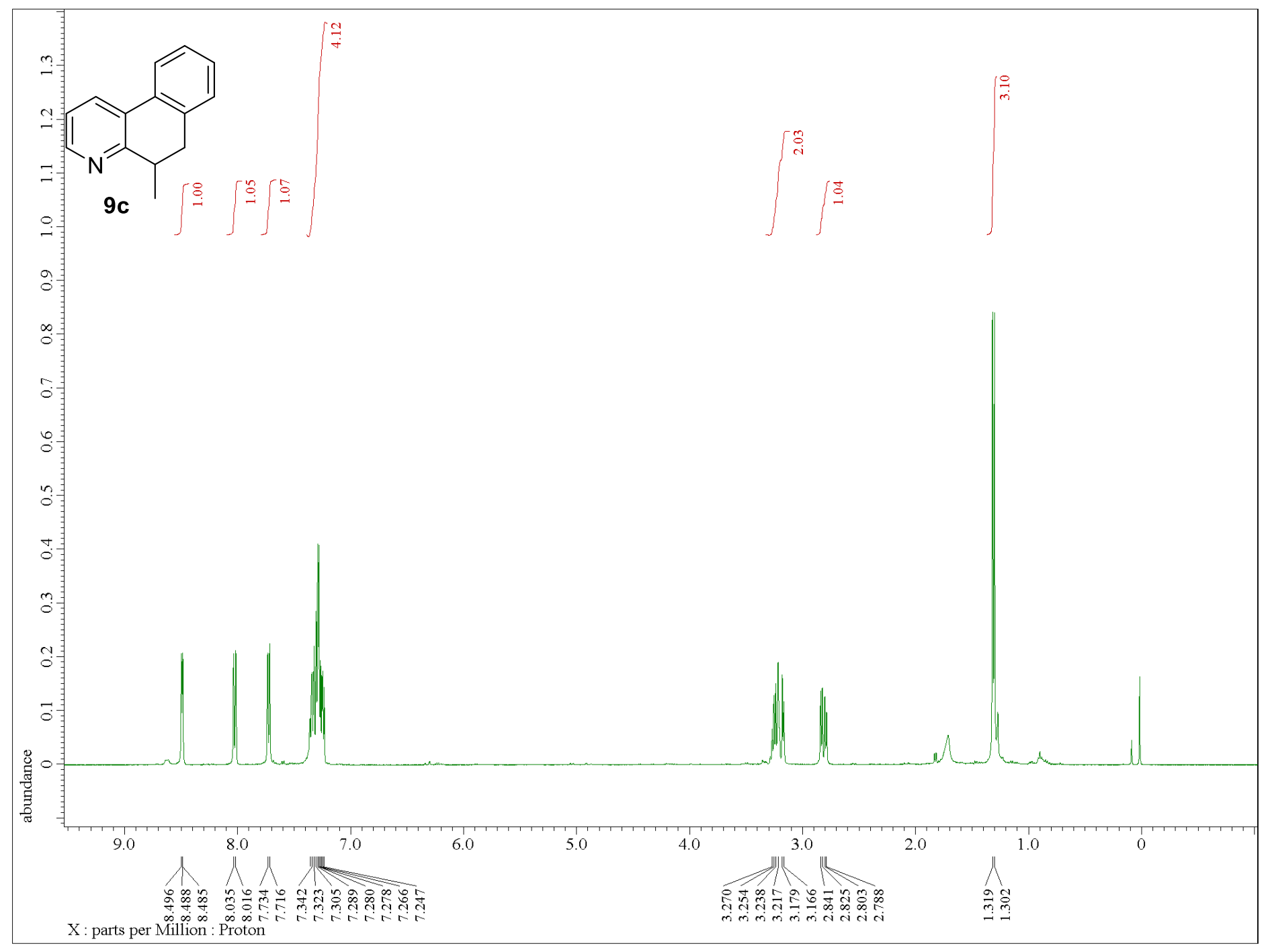

${ }^{1} \mathrm{H} \mathrm{NMR}, 400 \mathrm{MHz}, \mathrm{CDCl}_{3}$ 


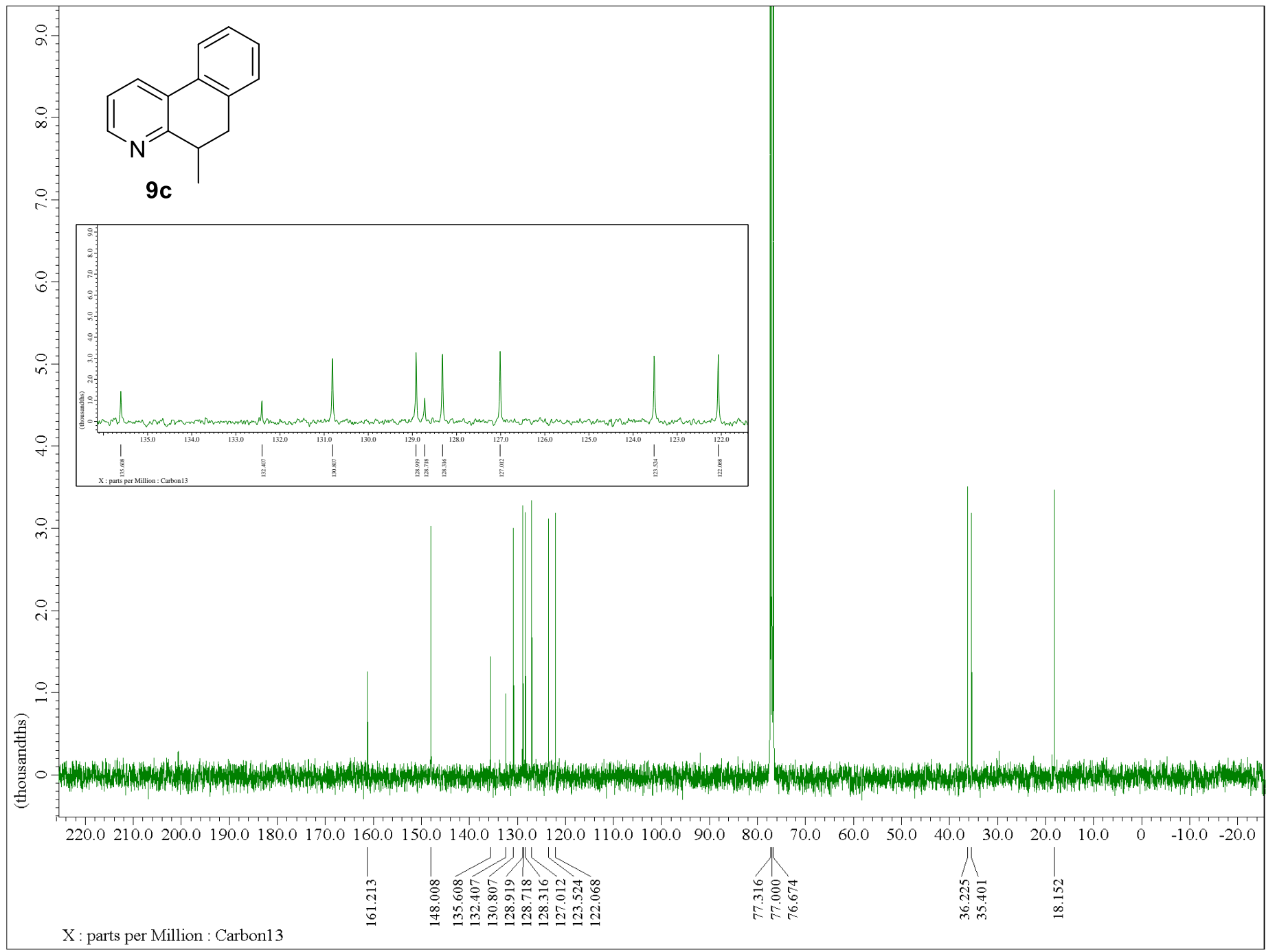

${ }^{13} \mathrm{C} \mathrm{NMR}, 100 \mathrm{MHz}, \mathrm{CDCl}_{3}$ 


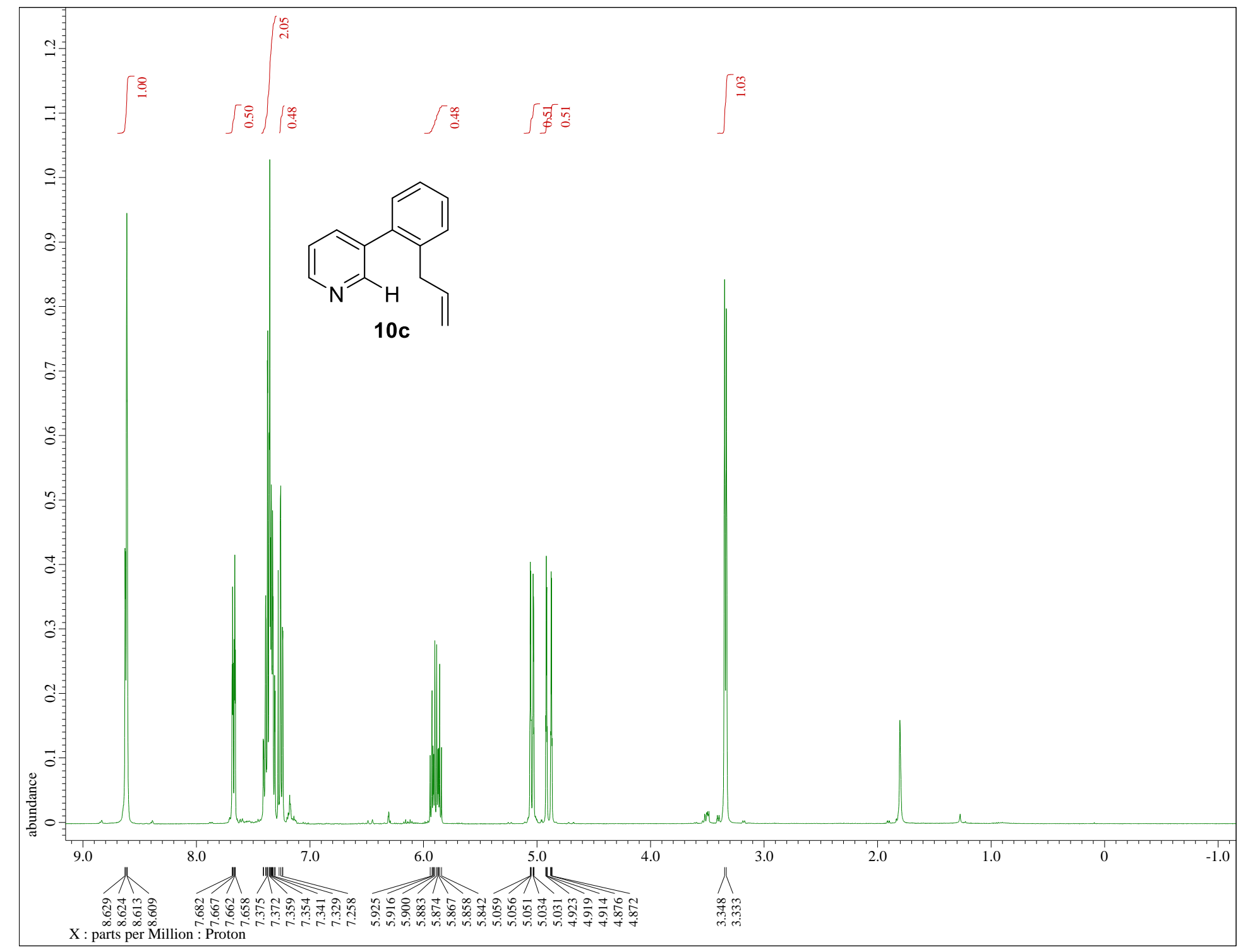

${ }^{1} \mathrm{H} \mathrm{NMR}, 400 \mathrm{MHz}, \mathrm{CDCl}_{3}$ 


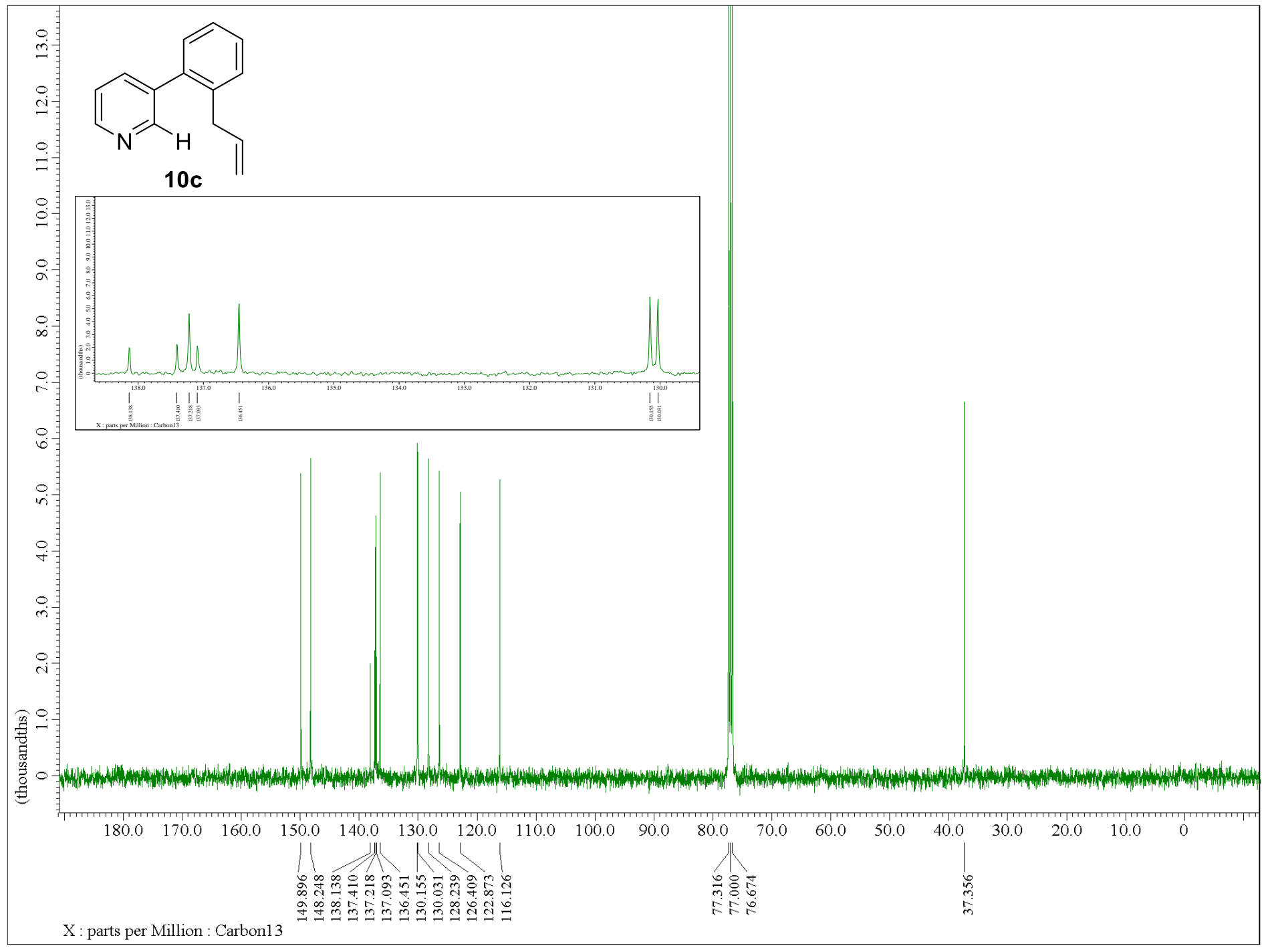

${ }^{13} \mathrm{C} \mathrm{NMR}, 100 \mathrm{MHz}, \mathrm{CDCl}_{3}$ 


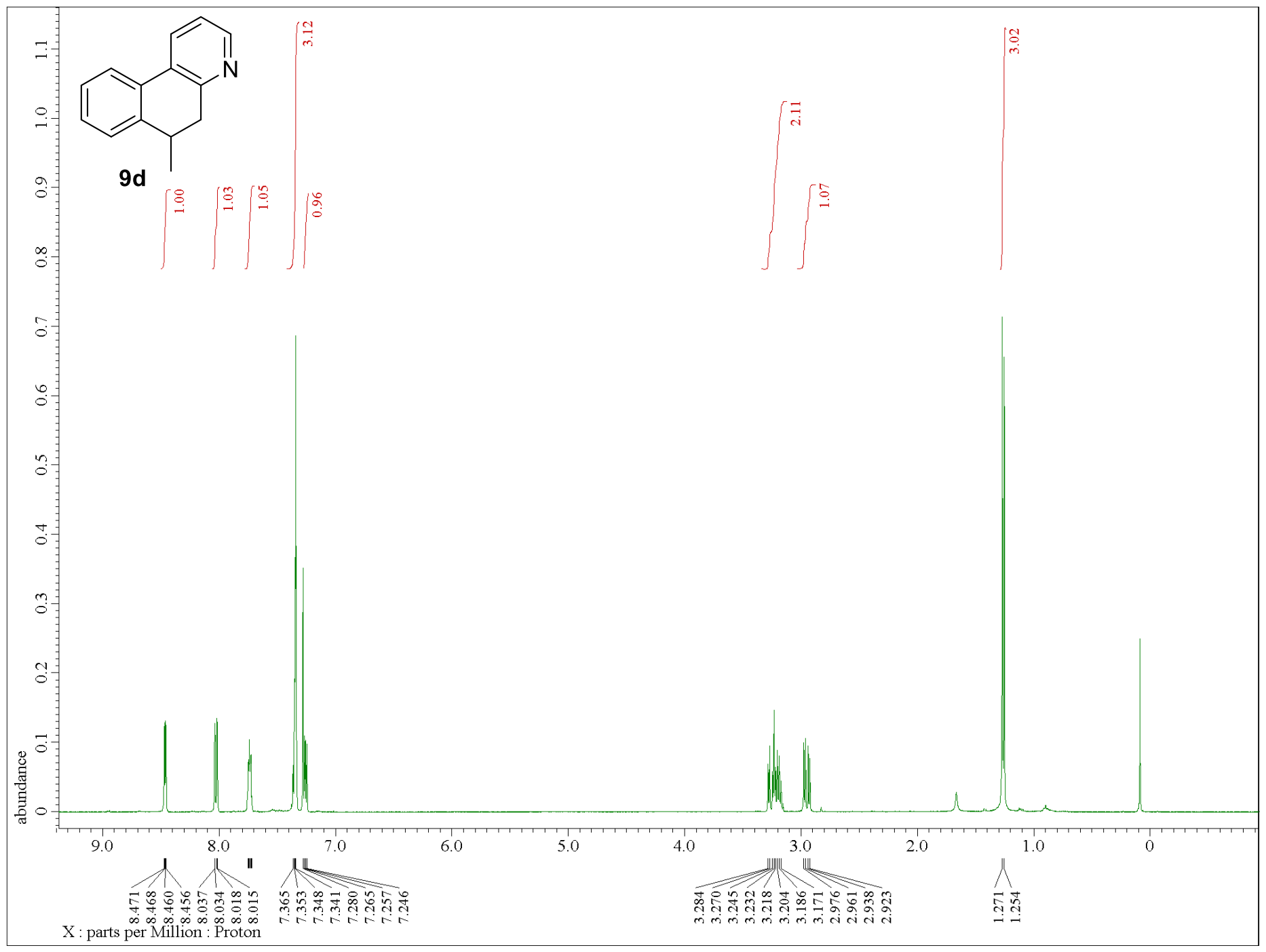

${ }^{1} \mathrm{H} \mathrm{NMR}, 400 \mathrm{MHz}, \mathrm{CDCl}_{3}$ 


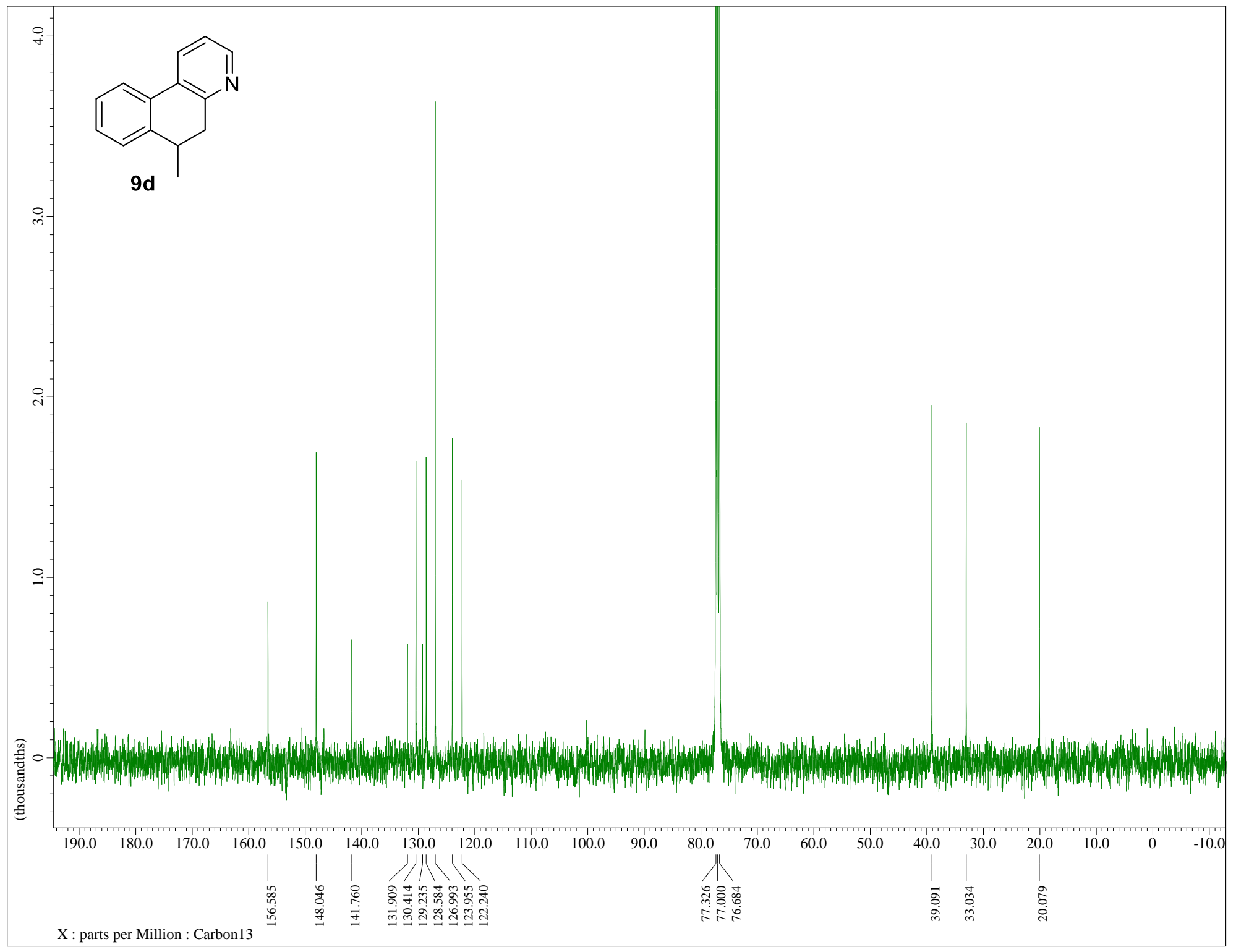

${ }^{13} \mathrm{C} \mathrm{NMR}, 100 \mathrm{MHz}, \mathrm{CDCl}_{3}$ 


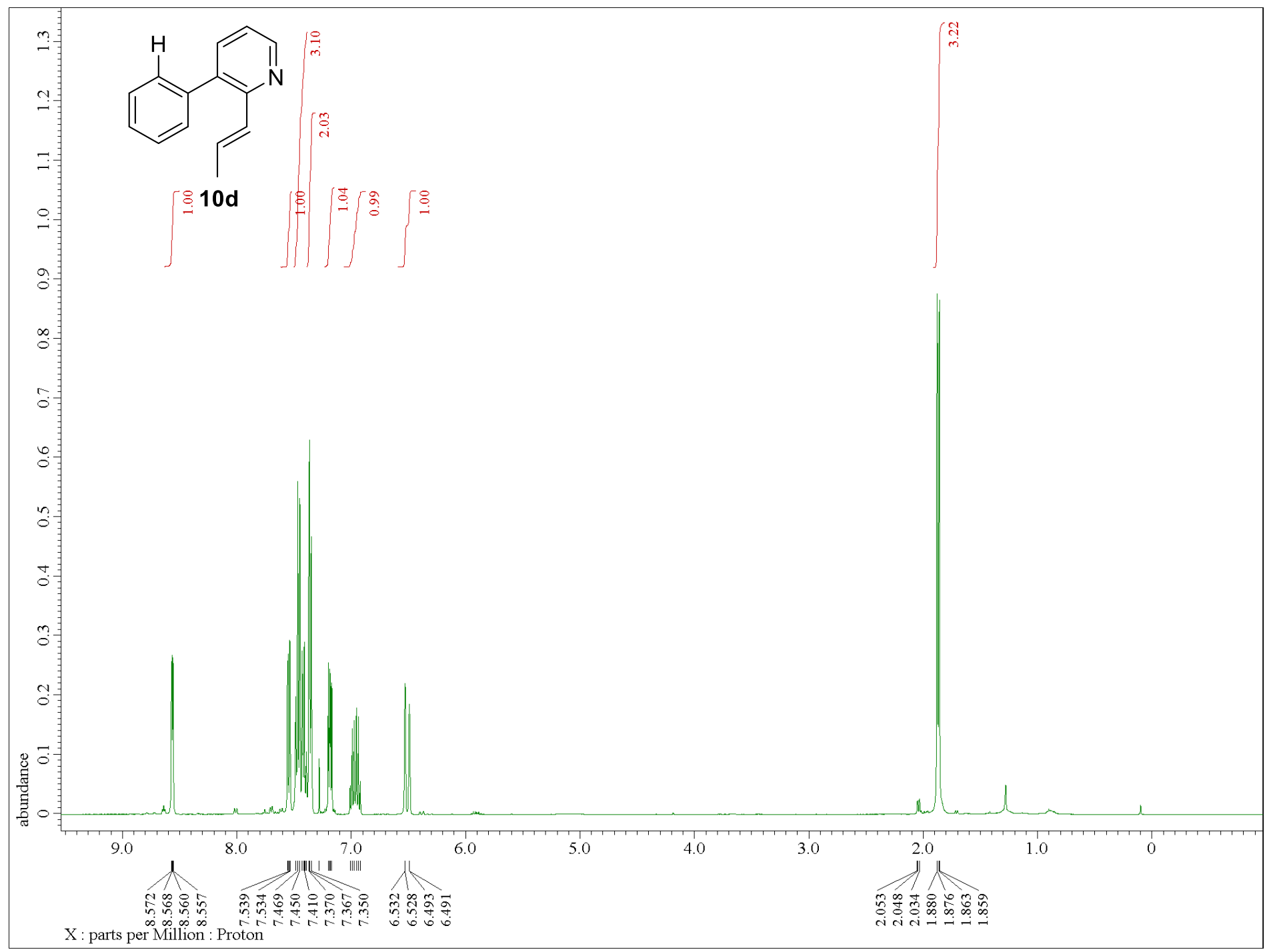

${ }^{1} \mathrm{H} \mathrm{NMR}, 400 \mathrm{MHz}, \mathrm{CDCl}_{3}$ 


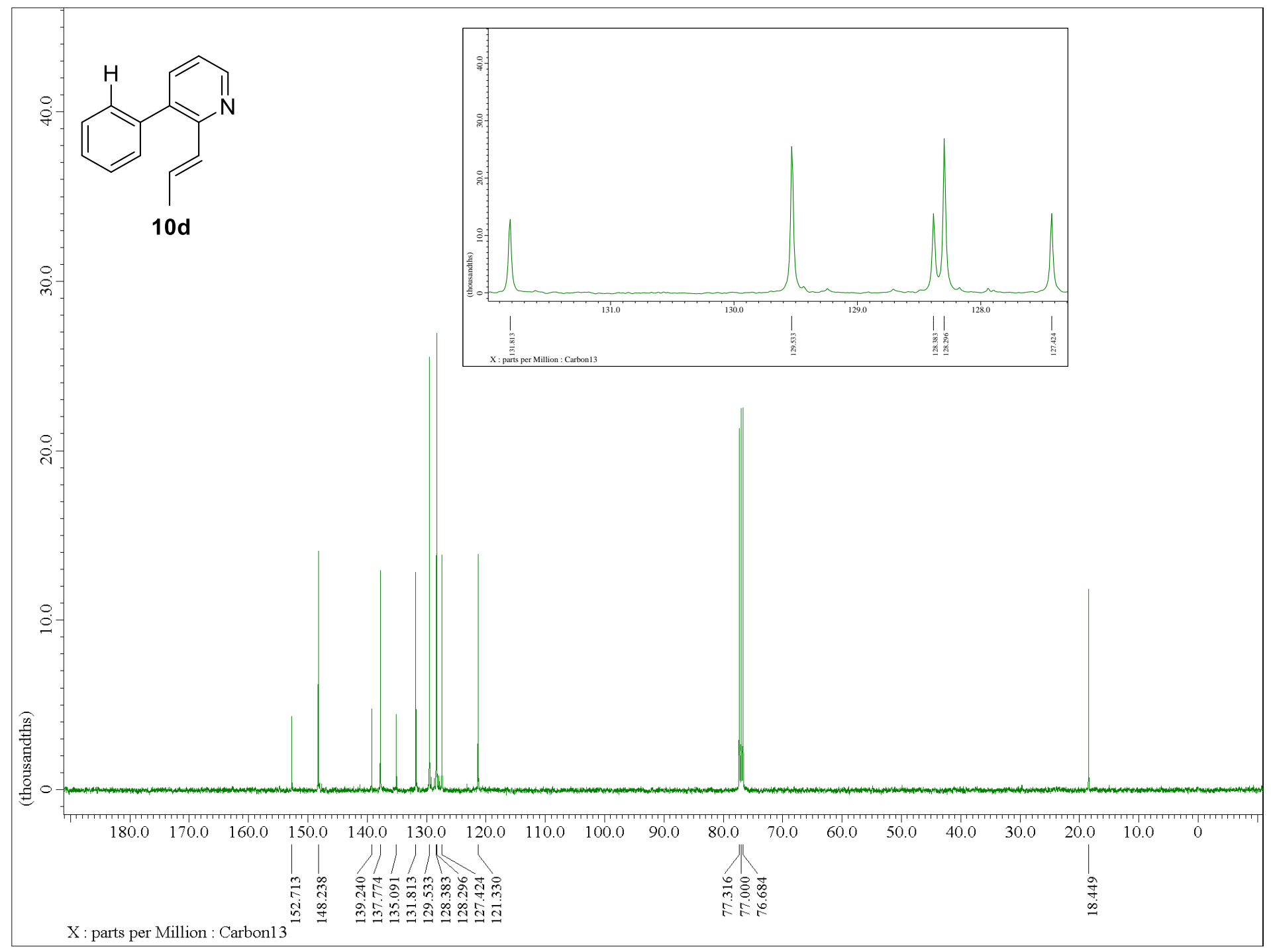

${ }^{13} \mathrm{C} \mathrm{NMR}, 100 \mathrm{MHz}, \mathrm{CDCl}_{3}$ 


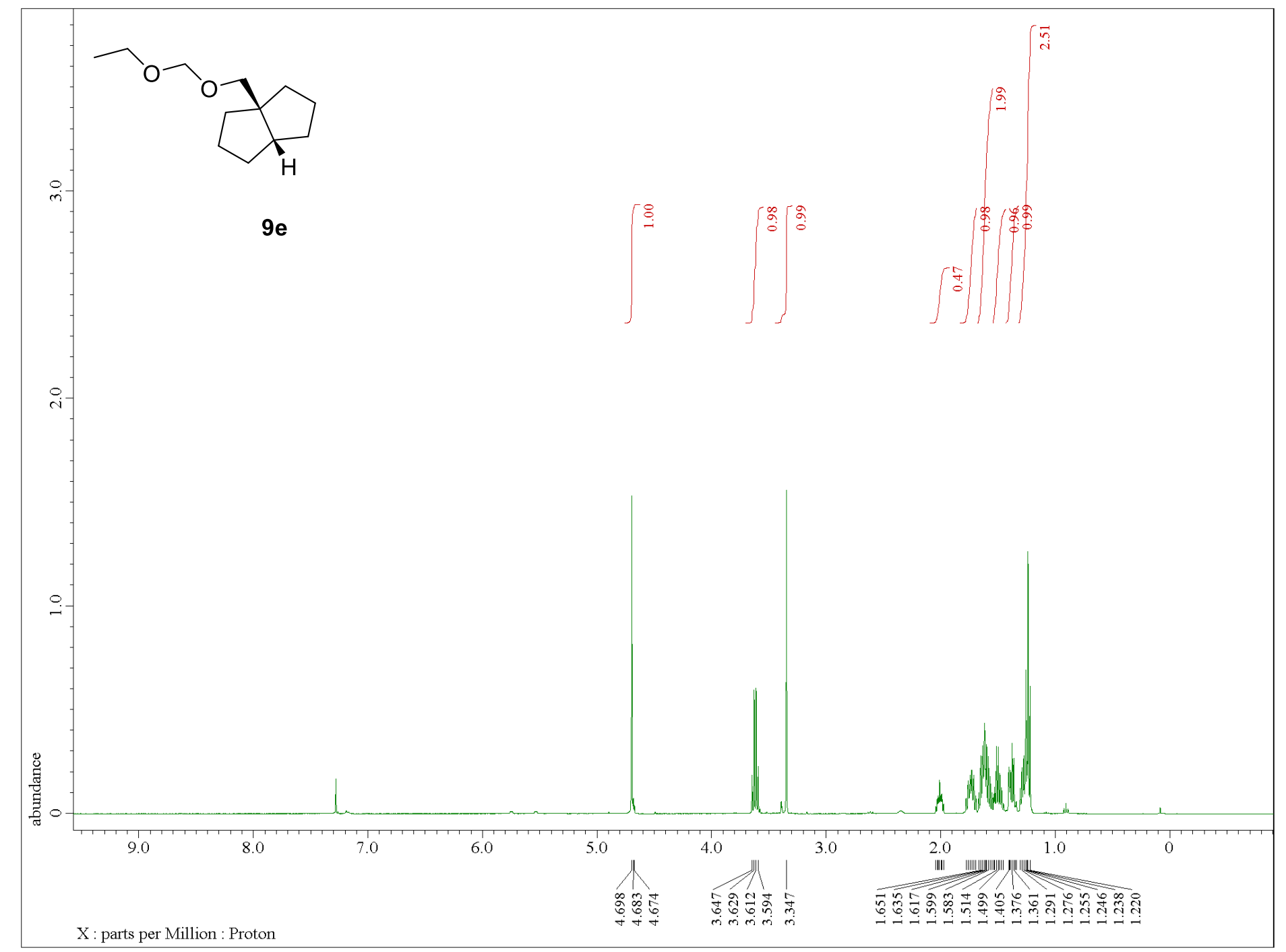

${ }^{1} \mathrm{H} \mathrm{NMR}, 400 \mathrm{MHz}, \mathrm{CDCl}_{3}$ 


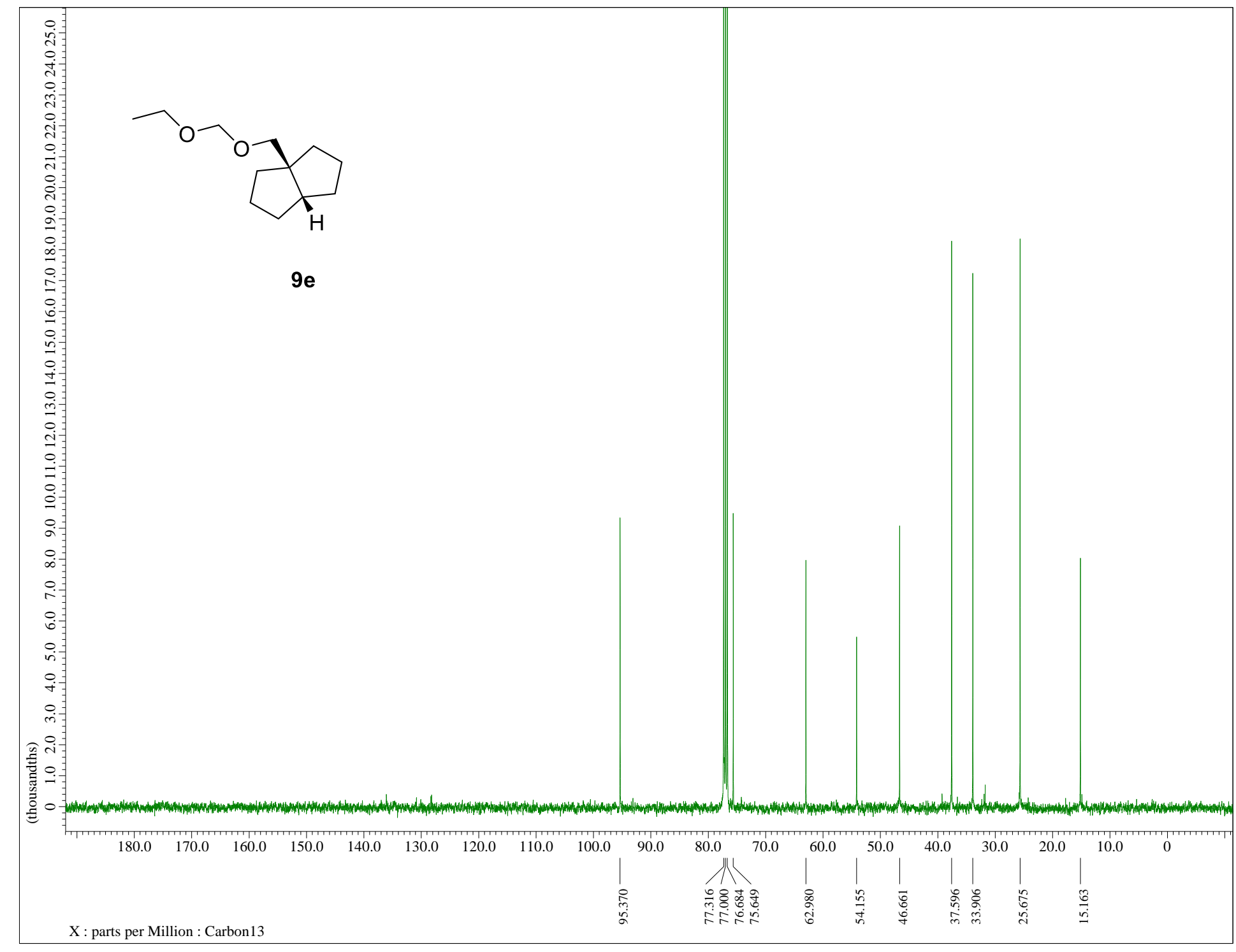

${ }^{13} \mathrm{C} \mathrm{NMR}, 100 \mathrm{MHz}, \mathrm{CDCl}_{3}$ 


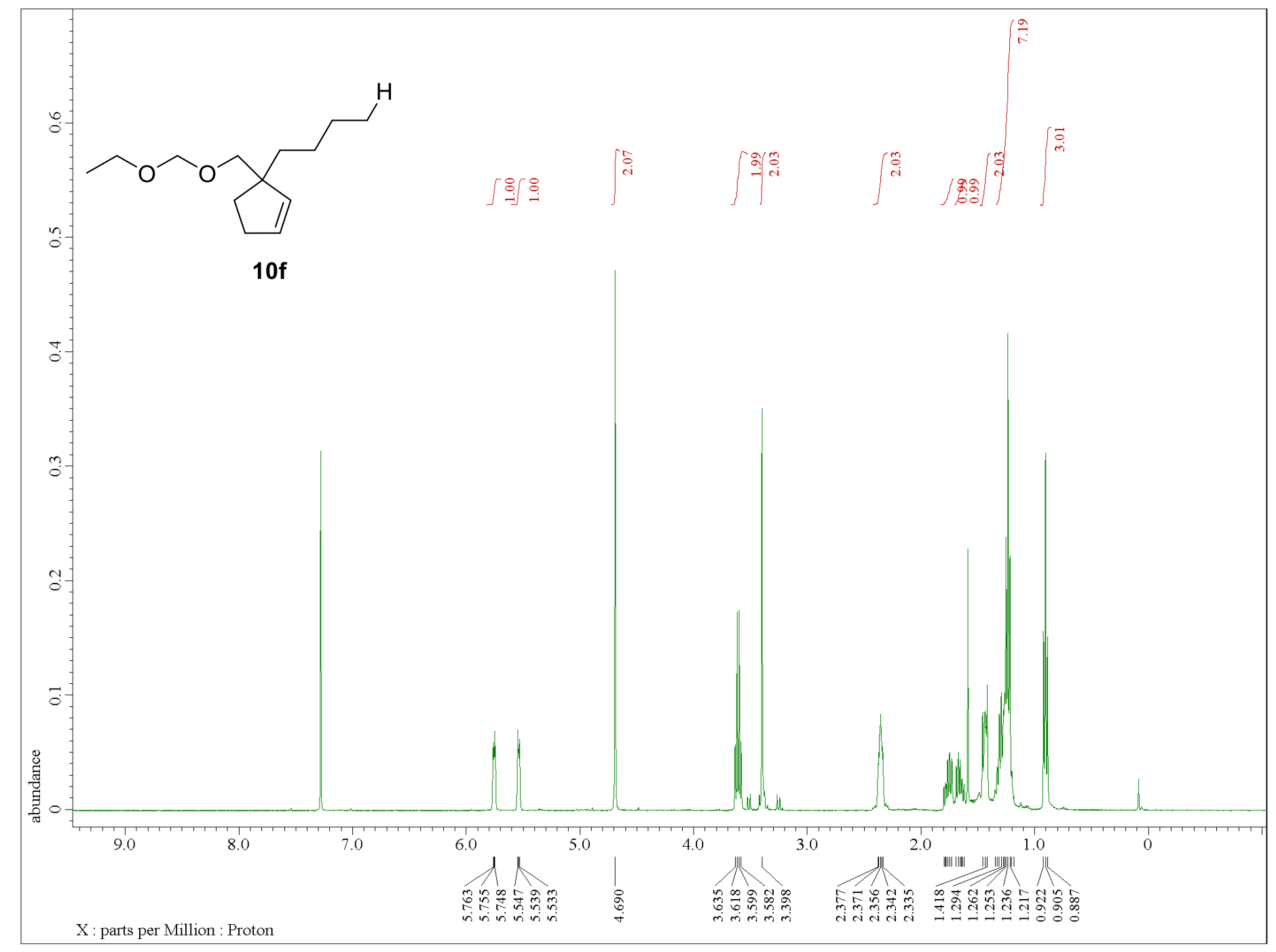

${ }^{1} \mathrm{H} \mathrm{NMR}, 400 \mathrm{MHz}, \mathrm{CDCl}_{3}$ 


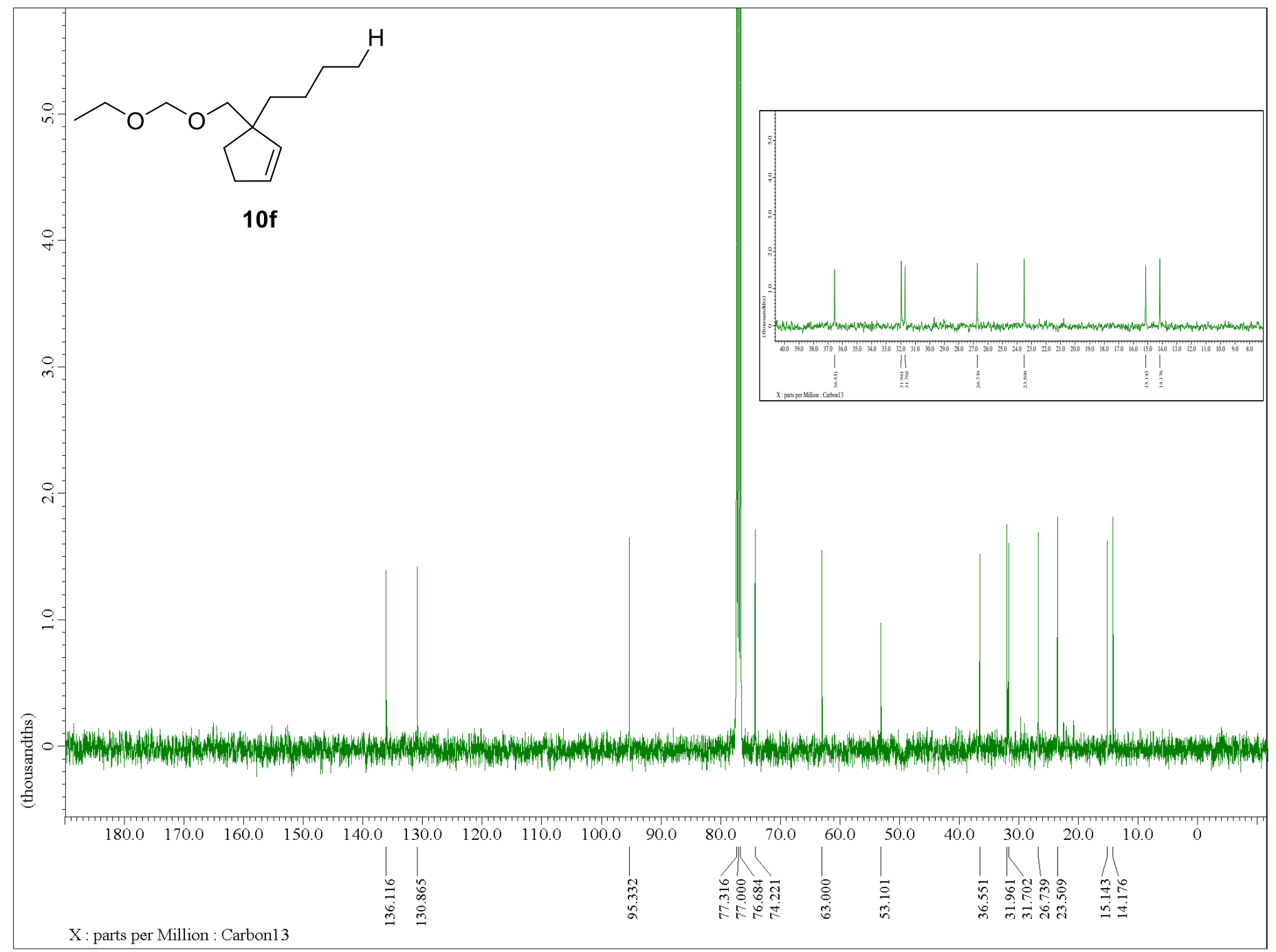

${ }^{13} \mathrm{C} \mathrm{NMR}, 100 \mathrm{MHz}, \mathrm{CDCl}_{3}$

S114 


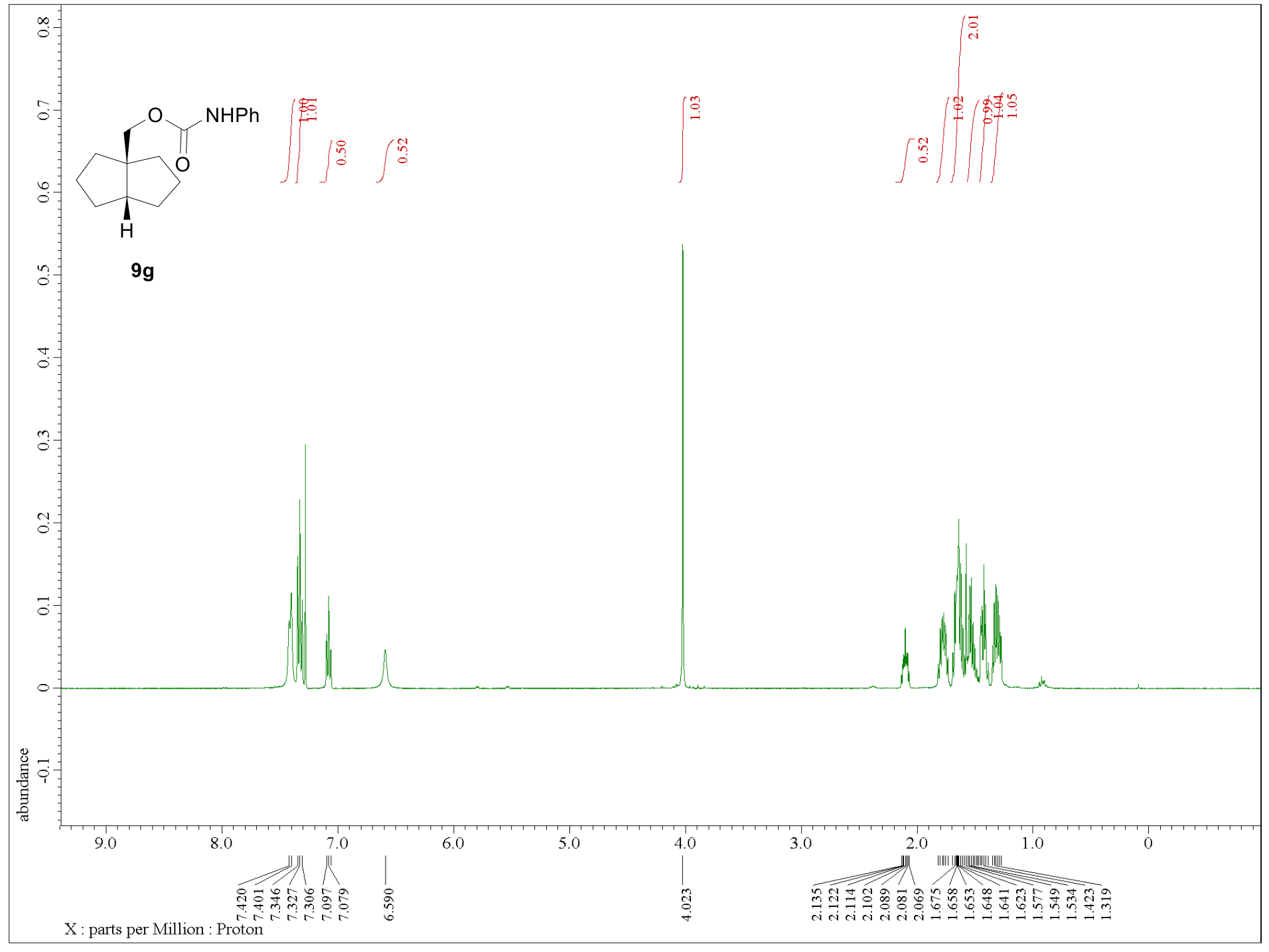

${ }^{1} \mathrm{H} \mathrm{NMR}, 400 \mathrm{MHz}, \mathrm{CDCl}_{3}$ 


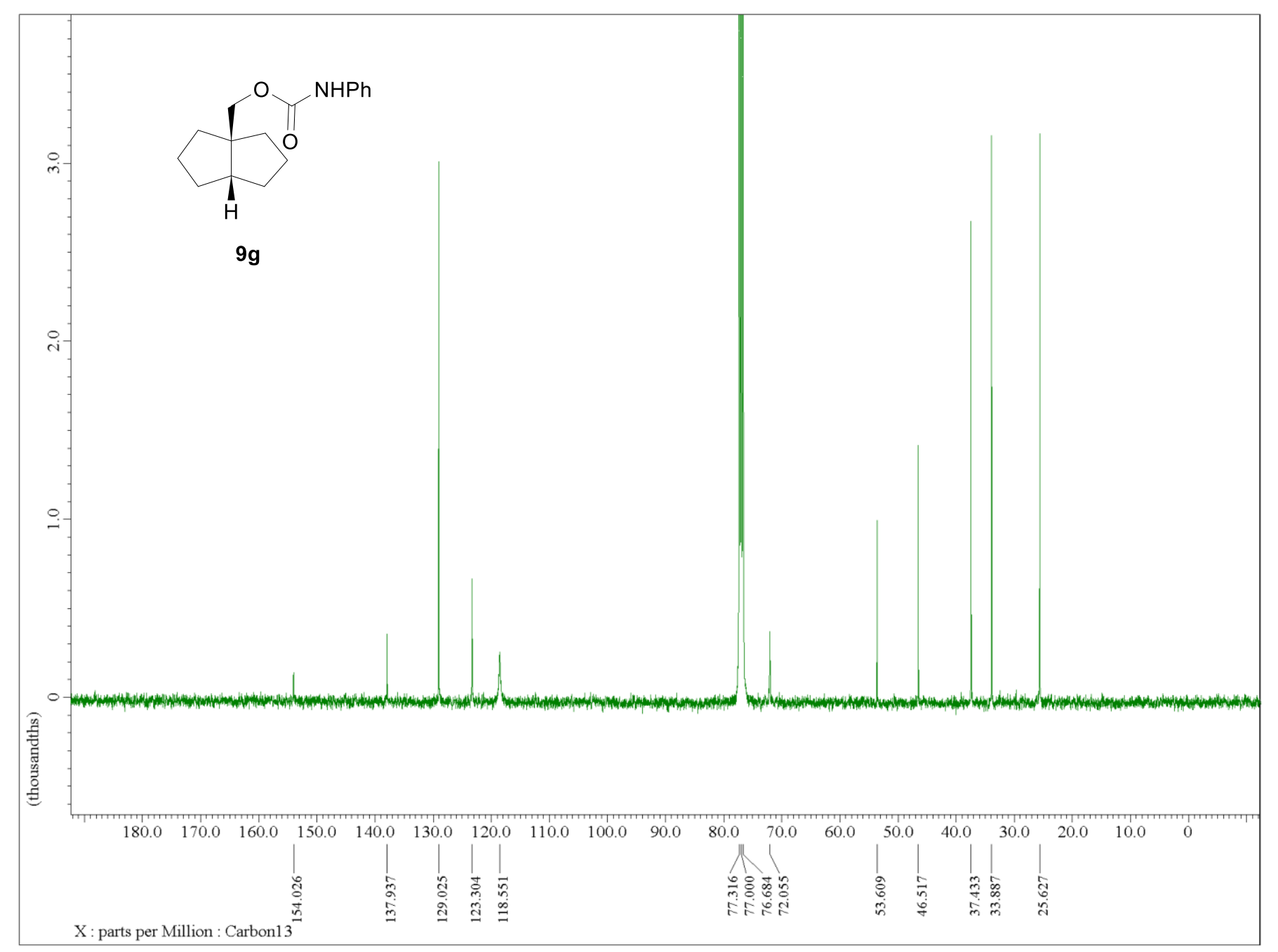

${ }^{13} \mathrm{C} \mathrm{NMR}, 100 \mathrm{MHz}, \mathrm{CDCl}_{3}$ 


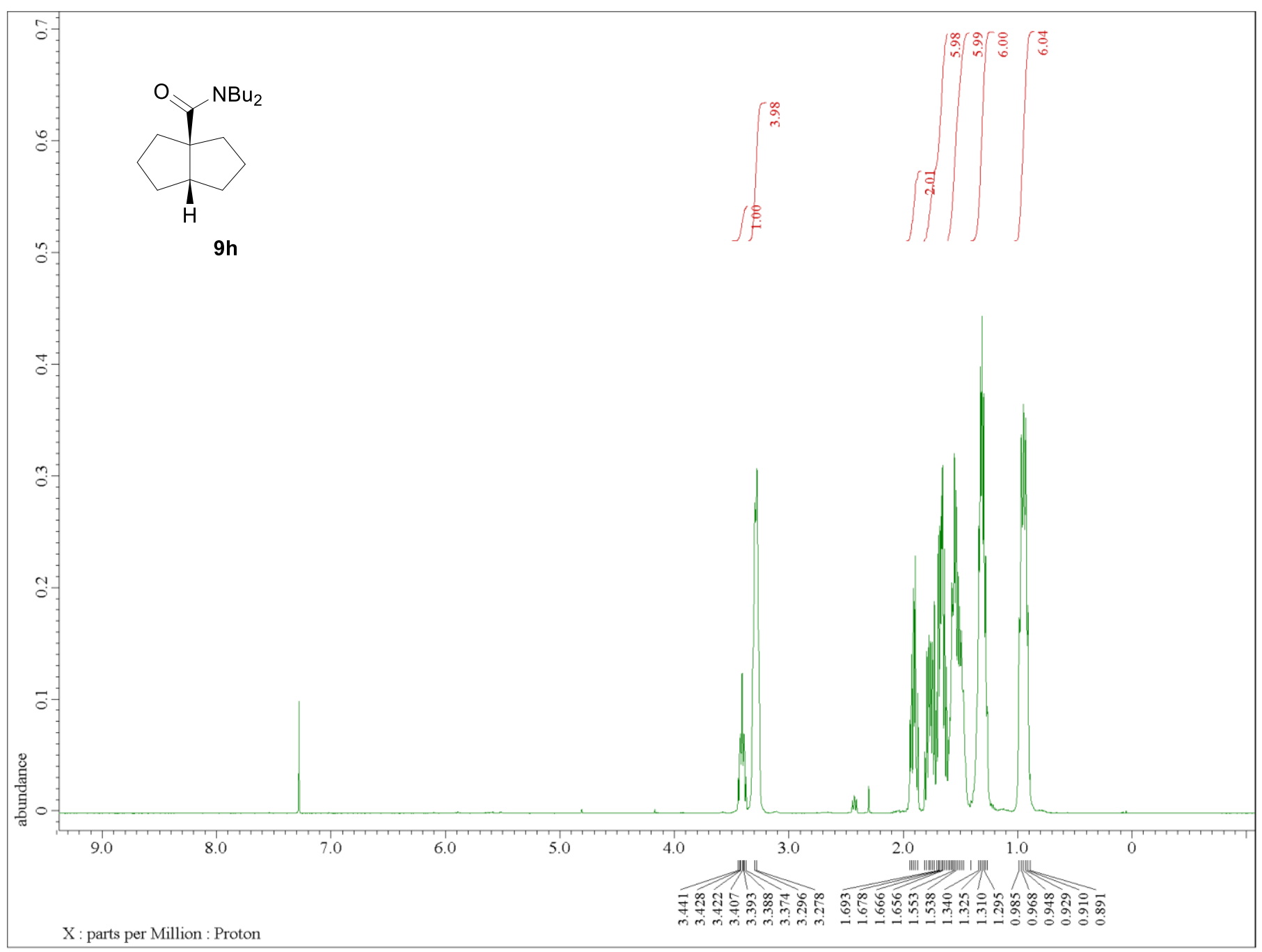

${ }^{1} \mathrm{H} \mathrm{NMR}, 400 \mathrm{MHz}, \mathrm{CDCl}_{3}$ 


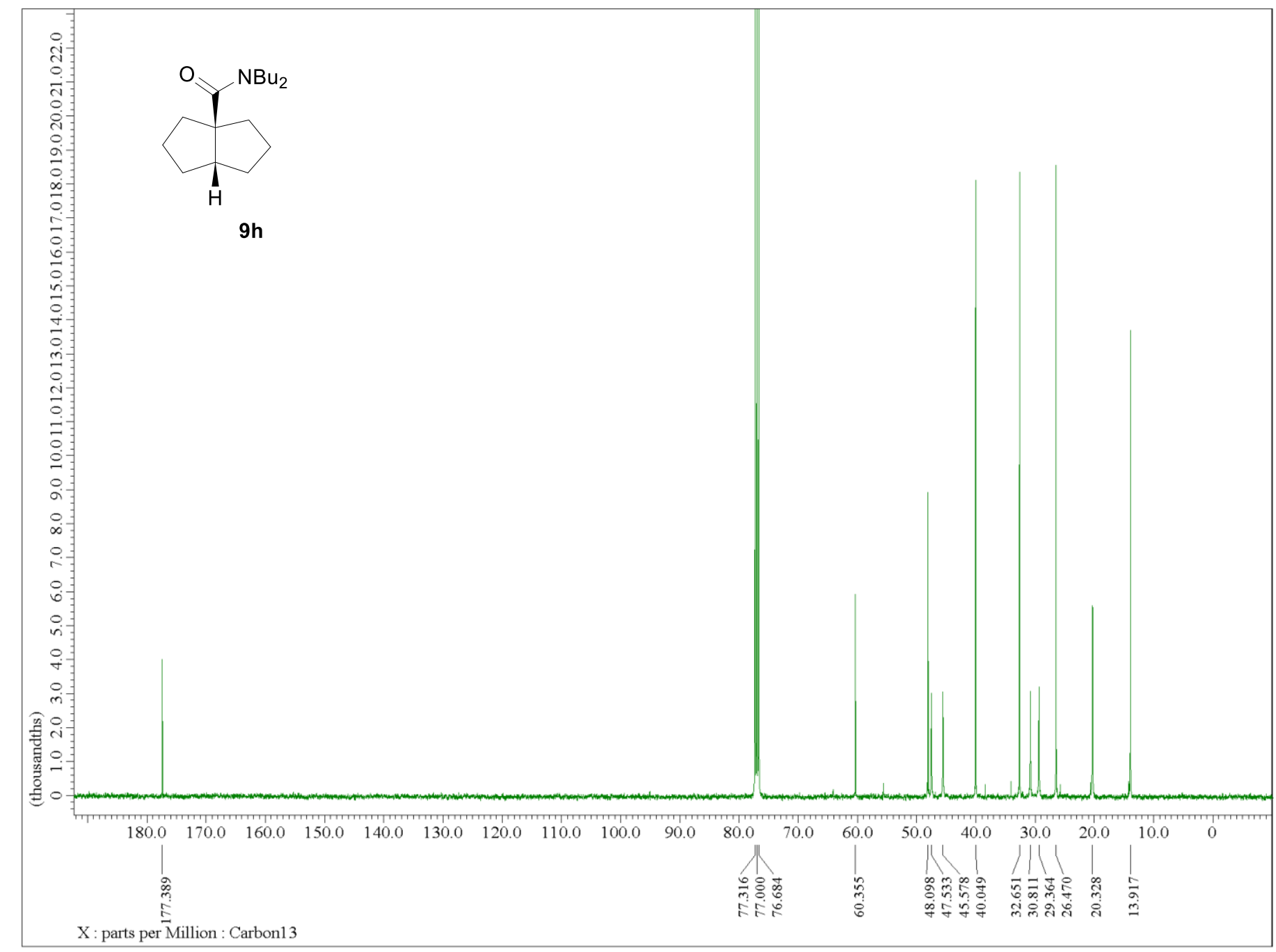

${ }^{13} \mathrm{C} \mathrm{NMR}, 100 \mathrm{MHz}, \mathrm{CDCl}_{3}$ 


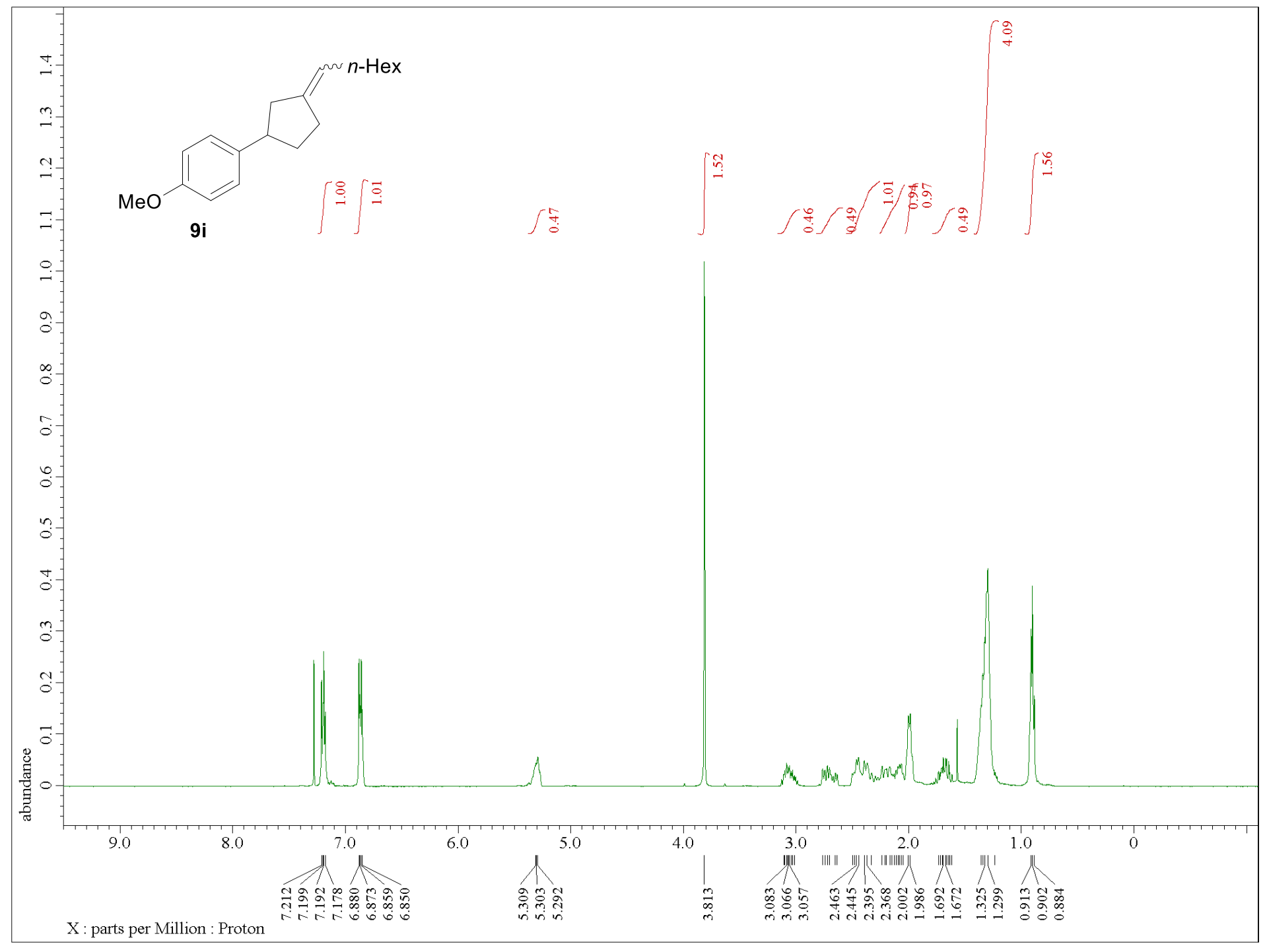

${ }^{1} \mathrm{H} N M R, 400 \mathrm{MHz}, \mathrm{CDCl}_{3}$ 


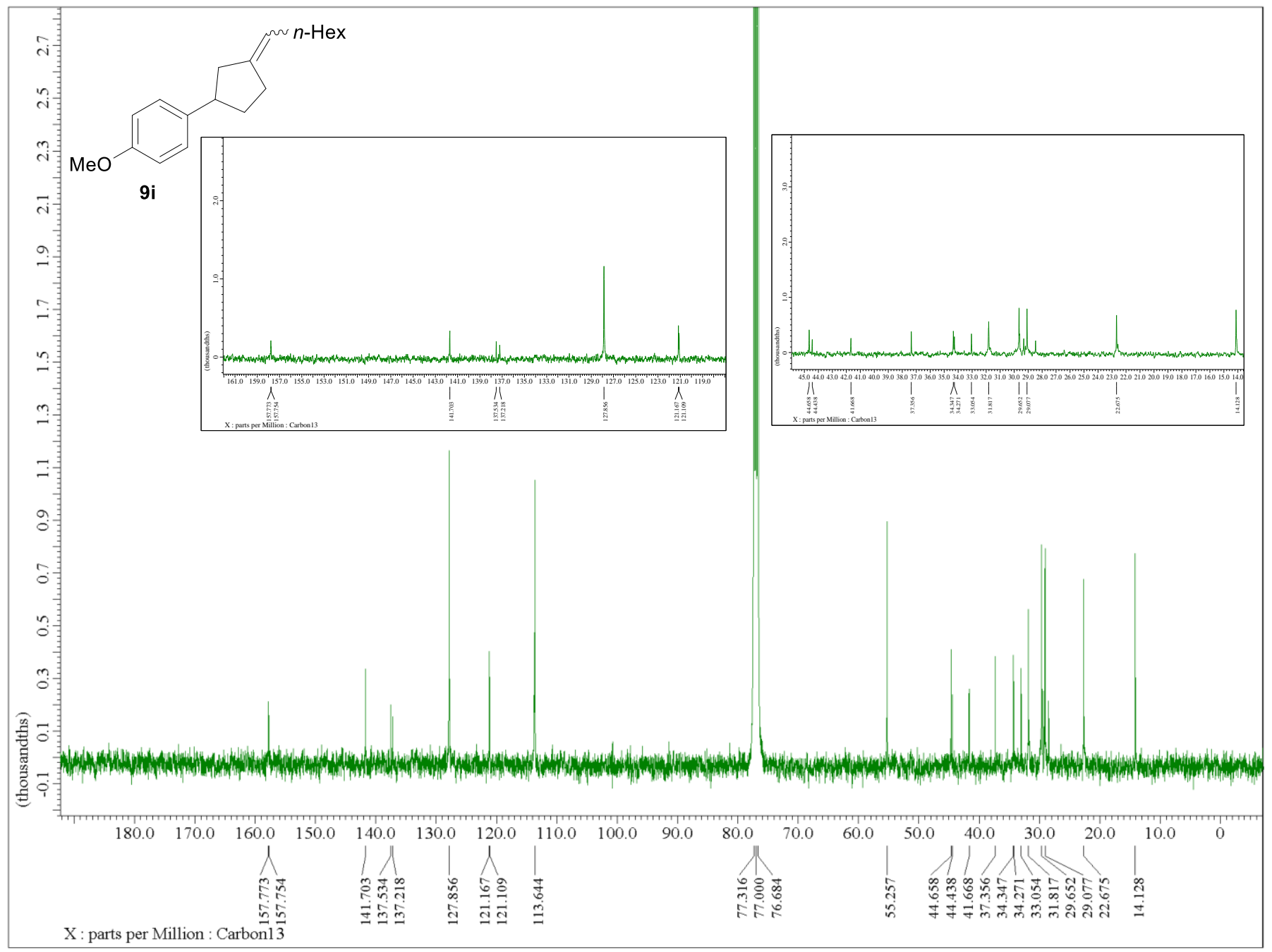

${ }^{13} \mathrm{C} \mathrm{NMR}, 100 \mathrm{MHz}, \mathrm{CDCl}_{3}$ 


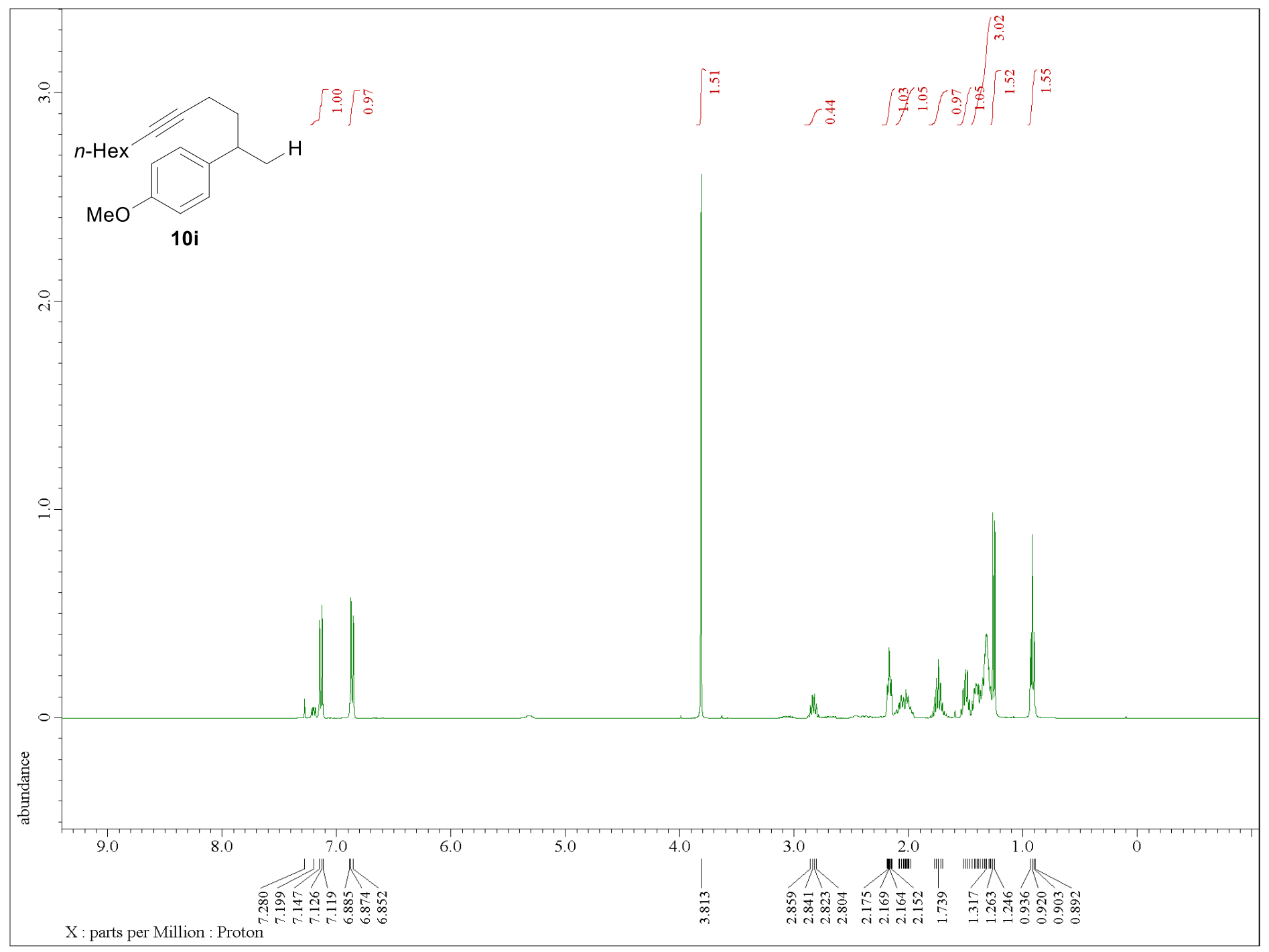

${ }^{1} \mathrm{H} N M R, 400 \mathrm{MHz}, \mathrm{CDCl}_{3}$ 


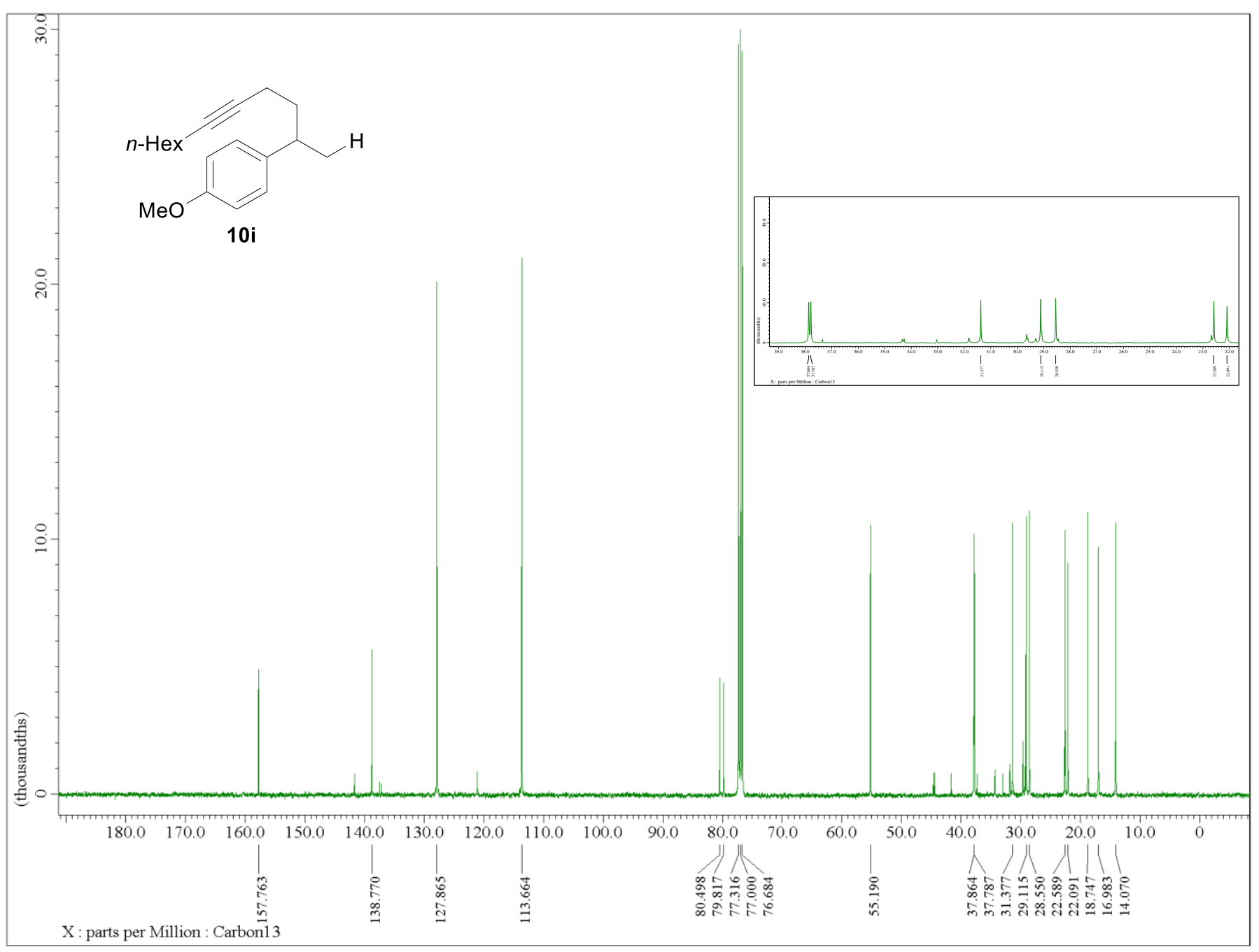

${ }^{13} \mathrm{C} \mathrm{NMR}, 100 \mathrm{MHz}, \mathrm{CDCl}_{3}$ 